University of Rhode Island

DigitalCommons@URI

Open Access Dissertations

1992

\title{
The Seismic Stratigraphy, Crustal Structure, Volcanic and \\ Sedimentary History of the East Mariana and Pigafetta Basins of the Western Pacific
}

Lewis Julius Abrams

University of Rhode Island

Follow this and additional works at: https://digitalcommons.uri.edu/oa_diss

\section{Recommended Citation}

Abrams, Lewis Julius, "The Seismic Stratigraphy, Crustal Structure, Volcanic and Sedimentary History of the East Mariana and Pigafetta Basins of the Western Pacific" (1992). Open Access Dissertations. Paper 413.

https://digitalcommons.uri.edu/oa_diss/413

This Dissertation is brought to you for free and open access by DigitalCommons@URI. It has been accepted for inclusion in Open Access Dissertations by an authorized administrator of DigitalCommons@URI. For more information, please contact digitalcommons-group@uri.edu. 
THE SEISMIC STRATIGRAPHY, CRUSTAL STRUCTURE, VOLCANIC AND SEDIMENTARY HISTORY OF THE EAST MARIANA AND PIGAFETTA BASINS OF THE WESTERN PACIFIC

BY

LEWIS JULIUS ABRAMS

A DISSERTATION SUBMITTED IN PARTIAL FULFILLMENT OF THE REQUIREMENTS FOR THE DEGREE OF DOCTOR OF PHILOSOPHY

IN

OCEANOGRAPHY

UNIVERSITY OF RHODE ISLAND 


\section{DOCTOR OF PHILOSOPHY DISSERTATION}

$\mathrm{OF}$

LEWIS JULIUS ABRAMS

APPROVED:

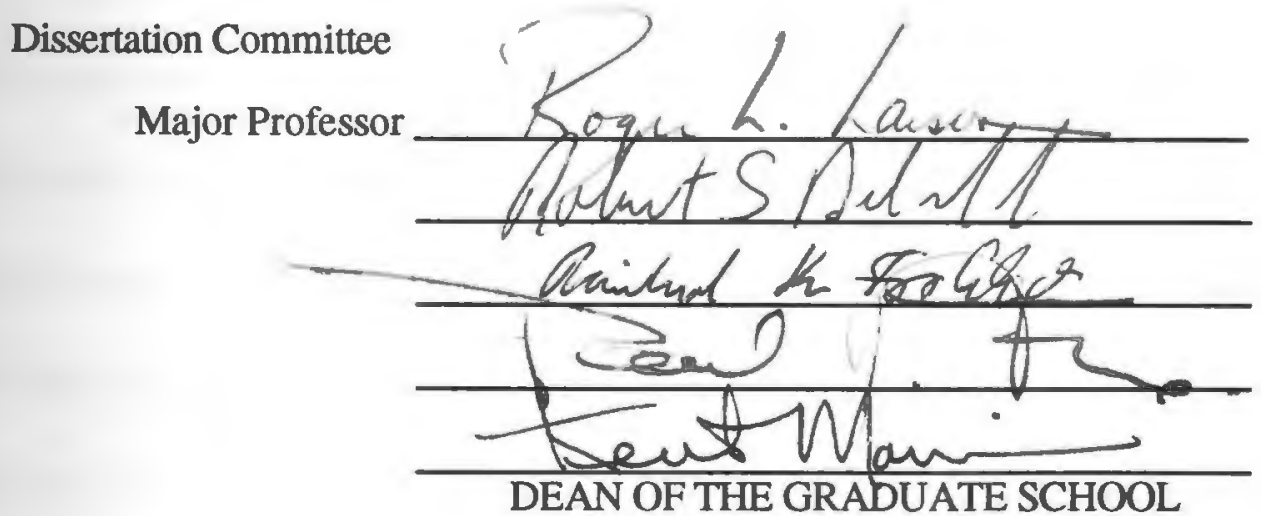

UNIVERSITY OF RHODE ISLAND 


\section{ABSTRACT}

In the following investigations regional multichannel seismic reflection and sonobuoy refraction data have been used to identify a site where Leg 129 of the Ocean Drilling Program (ODP) successfully drilled and recovered Jurassic material for the first time in the Pacific Ocean. Prior to drilling first-order stratigraphic relationships and crustal structure were determined. The sedimentary and volcanic history of the East Mariana Basin (EMB) and Pigafetta Basin (PB) were then inferred with emphasis on defining the extent (lateral as well as vertical) and type of deep sea volcanic provinces (sills/flows and or volcaniclastics) in this part of the western Pacific .

The successful completion of ODP Leg 129, resulting in the first and only holes to penetrate igneous basement in the EMB and PB, allows the calibration of our regional multichannel seismic site surveys and the extrapolation of drilling results throughout these oldest Pacific basins. Our study indicates that mid Cretaceous flows/sills overlie Jurassic/ Early Cretaceous sediments and oceanic crust throughout an area $\sim 500,000 \mathrm{~km}^{2}$ in the EMB and the southeast PB. Jurassic age oceanic crust and overlying upper Jurassic lower Cretaceous pelagic sediments unquestionably exist at Site 801 and extend semicontinuously between Site 801 and Site 800 . A "Rough-Smooth" Horizon B boundary marks the termination of continuous mid-Cretaceous volcanic overburden. Volcanogenic turbidite sequences of varying thicknesses and ages are ubiquitous features of both basins. The Ogasawara Fracture Zone, Magellan Seamounts and associated flexural moat separate the PB from the EMB and influence the source and distribution of this redeposited material. This study places constraints on the depth to basement and crustal thickness in 
these oldest ocean basins which, when coupled with recently acquired heatflow measurements (Lister et al., 1990; Stein and Abbot, 1991), favor a time-varying heat flow model as a possible explanation for the observed divergence of heatflow and depth versus age from that predicted by a simple cooling boundary layer. These observations are consitent with those compiled in Larson $(1991 \mathrm{a}, \mathrm{b})$, where increased mantle temperatures due to vigorous global plume activity are rapidly initiated at approximately $124 \mathrm{ma}$ and gradually decrease toward $80 \mathrm{ma}$. 


\section{ACKNOWLEDGEMENT}

I am grateful to my major advisor Roger Larson for inviting me along for the final stages of the "quest for the Jurassic Pacific". After jumping off the R/V Fred Moore as it began to sink dockside in the harbor of the Micronesian island of Pohnpei and as Roger, Yves Lancelot, Tom Shipley et al., headed into the lagoon for "Joy" island, I thought then as I do now, that this is really much more exciting than graduate school is supposed to be. I am thankful to Roger for expressing his confidence in my ability by allowing me to participate as a colleague during the planning and real time decision making during the MCS and drilling expeditions to the western Pacific. I would also like to thank Roger, Tom Shipley and Yves Lancelot for their guidance and friendship during our adventures in the western Pacific and in the laboratory at the Institute for Geophysics in Austin (UTIG) and at the Institut de Physique du Globe, Strasbourg (IPG). Tom Shipley was especially helpful with his insights, suggestions and many reviews of the manuscripts in this dissertation. This dissertation has benefitted substantially from the comments and suggestions of my Ph.D. committee; Roger Larson, Bob Detrick, Reinhard Frohlich and Jeff Fox and I thank Dan Murray for acting as chairman of this committee. In addition, Jeff Fox generously allowed the use of his laboratory facilities and his extensive reference collection.

A great deal of effort was made on behalf of myself and this project during the processing of nearly $8000 \mathrm{~km}$ of MCS data by Steffen Saustrup, Mark Wiederspahn, Patty Ganey at UTIG and Marc Schaming, Jacques Renault, Cecille Pourcellot and Roland Schlich at IPG, Strasbourg and Jim Dolan at GSO/URI. I am indebted to John Mutter who provided free use of the L-DGO seismic processing facilities and to John Diebold and Emilio Vera who provided software (JDSEIS) and much advise concerning sonobuoy analysis. Rob Pockalny, who actually received a Ph.D. last year, continues to 
be a pretty good option quarterback and for "bread and butter right", two intramural football championships and a fake beach volleyball - go camping ploy, I thank him. My family has given me their enthusiastic support throughout my graduate school career and through every endeavor that I have chosen to pursue, without their help I would not have had the luxury of achieving a Ph.D.

I am especially thankful for the now "Dr." Nancy Grindlay, who, even though she got married, found the time to review and discuss these manuscripts and provide continuous support and encouragement...if you know what I mean. 


\section{PREFACE}

The majority of the seismic reflection/refraction data analyzed in this dissertation were collected on two separate expeditions to the western Pacific aboard the $R N$ Fred Moore in the fall of 1987 and aboard the N/O Le Suroit in the fall of 1989. During these cruises, the first multichannel seismic experiments in this area of the western Pacific were conducted. The oceanographic scientific community has, for over 20 years, been convinced of the importance of examining the potentially oldest oceanic crust left in-situ on the planet as well as the overlying sediments deposited in the Jurassic super ocean at the time before the complete breakup of Pangea. The ultimate goal of drilling and recovering Jurassic age oceanic crust and overlying sediment in order to piece together the volcanic, sedimentary and environmental history of the oldest oceans and ocean basins was thwarted by the apparently ubiquitous shallow cherts or massive younger basalt sills/flows which were overlying oceanic crust. Eight scientific drilling expeditions beginning in 1969 on DSDP Leg 6 were devoted to the "Quest for the Jurassic Pacific" but were unsuccessful. Thematic panels were, to say the least, "a bit gun shy" at the prospect of devoting any further drilling expeditions to this quest, however, the initial results of the work presented in this dissertation provided convincing evidence that oceanic crust in restricted areas of the far western Pacific could be reached with available drilling technology. Three months after we collected the last of our MCS data, Jurassic material was drilled and brought on board the JOIDES Resolution during ODP Leg 129.

This dissertation is presented in manuscript format and consists of three manuscripts with an appendix which when combined, represents the most comprehensive study to date of the seismic stratigraphy, sedimentary history and crustal structure of the oldest Pacific basins. I am lead author on manuscripts one and two and a co-author on the third manuscript. 
Manuscript I "Cretaceous volcanic sequences and Jurassic oceanic crust in the East Mariana and Pigafetta Basins of the western Pacific" has been submitted for publication in an American Geophysical Union Monograph entitled "The Mesozoic Pacific", M. Pringle and W. W. Sager editors.

Manuscript II "The seismic stratigraphy and sedimentary history of the East Mariana and Pigafetta Basins of the western Pacific" has been submitted for publication in the Ocean Drilling Program Leg 129 Scientific Results Volume, R. L. Larson and Y. Lancelot editors.

Manuscript III "Comparison of laboratory and logging data from Leg 129 and the inversion of logs to determine lithology" has been submitted for publication in the Ocean Drilling Program Leg 129 Scientific Results Volume, R. L. Larson and Y. Lancelot editors.

The co-authors for the first two manuscripts are Roger Larson (GSO/URI), Tom Shipley (Institute for Geophysics, University of Texas, Austin), and Yves Lancelot (Laboratoire de Geologie du Quaternaire, CNRS, Marseille, France). The lead author on the third manuscript is Andrew Fisher (Ocean Drilling Program - Texas A\&M University) and William Busch (Department of Geology and Geophysics, University of New Orleans) is a co-author.

Although not included as part of my dissertation, I made contributions to, and am co-author on, several other publications which relied on the data from the cruises mentioned above as well as two reflection/refraction experiments conducted in the Nauru Basin, western Pacific. These cruises were conducted on the N/O Charcot (Spring 1987) and $R V$ Thomas Washington (Winter 1988-89). Except for the cruise aboard N/O Charcot, I participated in all phases (proposal - data acquisition, processing and interpretation - publication of the results) of the three MCS and one drilling expedition to the western Pacific. I am a co-author of the manuscript entitled "Extent of Cretaceous 
Volcanic Sequences in the Jurassic Nauru Basin" submitted to the American Geophysical Union Monograph entitled "The Mesozoic Pacific". This manuscript compliments the research presented in this dissertation and represents a collaborative effort of Tom Shipley (lead author), Roger Larson, Yves Lancelot and myself. Finally, I am lead author of the seismic stratigraphy and downhole logging sections in the Site chapters of the ODP Leg 129 Initial Reports Volume published in December 1990. The research presented in this dissertation is a direct result of further analysis of the data presented in the ODP Leg 129 Initial Reports volume.

Appendix A includes further details concerning the morphology and geophysical attributes of the Ogasawara Fracture Zone and Flexural Moat. Models of this area are presented and discussed in reference to the results reported in the main body of the dissertation. 


\title{
TABLE OF CONTENTS
}

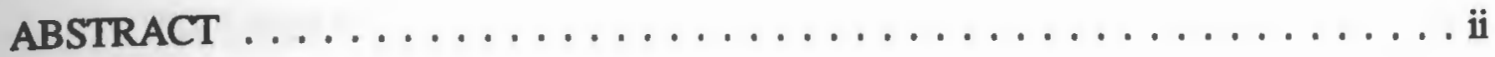

ACKNOWLEDGEMENT $\ldots \ldots \ldots \ldots \ldots \ldots \ldots \ldots \ldots \ldots$ iv

PREFACE $\ldots \ldots \ldots \ldots \ldots \ldots \ldots \ldots \ldots \ldots \ldots \ldots \ldots \ldots \ldots \ldots \ldots$

LIST OF TABLES $\ldots \ldots \ldots \ldots \ldots \ldots \ldots \ldots \ldots \ldots \ldots \ldots \ldots \ldots \ldots \ldots \ldots$

LIST OF FIGURES $\ldots \ldots \ldots \ldots \ldots \ldots \ldots \ldots \ldots \ldots$
\end{abstract}

MANUSCRIPT I: Cretaceous volcanic sequences and Jurassic oceanic crust in the

East Mariana and Pigafetta Basins of the western Pacific . . . . . . . . . . . . 1

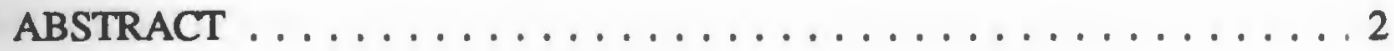

INTRODUCTION $\ldots \ldots \ldots \ldots \ldots \ldots \ldots \ldots$

DATA ACQUISITION AND PROCESSING $\ldots \ldots \ldots \ldots \ldots$

Sonobuoy Methods and Analyses . . . . . . . . . . 7

TECTONIC SETTING $\ldots \ldots \ldots \ldots \ldots \ldots \ldots \ldots$

PREVIOUS STUDIES $\ldots \ldots \ldots \ldots \ldots \ldots \ldots \ldots$

Western Pacific Seismic Stratigraphy $\ldots \ldots \ldots \ldots \ldots \ldots$

Leg 129 Site Review . . . . . . . . . . . . . . . . . 13

SEISMIC OBSERVATIONS AND RESULTS . . . . . . . . . . . . . 14

General Characterization of Horizon B . . . . . . . . . . . 14

Horizon $B$ in the East Mariana Basin . . . . . . . . . . . . 15

Horizon $\mathrm{B}$ in the Pigafetta Basin $\ldots \ldots \ldots \ldots \ldots$ 
Sill/Flow/Sediment Thickness . . . . . . . . . . . . . . . . 20

DISCUSSION . . . . . . . . . . . . . . . . . 24

Tectonic Setting and Source of Deep Sea Volcanics . . . . . . . . . 26

Magnetic Rough-Smooth Boundary . . . . . . . . . . 30

CONCLUSIONS ............................ 31

ACKNOWLEDGEMENT . . . . . . . . . . . . . . . 33

TABLES AND FIGURES $\ldots \ldots \ldots \ldots \ldots$

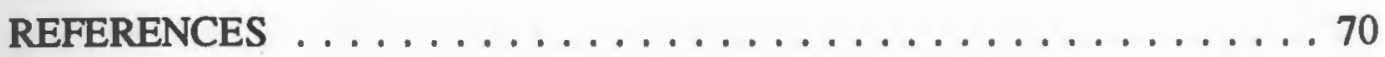

MANUSCRIPT II: Seismic Stratigraphy and Sedimentary History of the

East Mariana and Pigafetta Basins of the western Pacific . . . . . . . . . . . 83

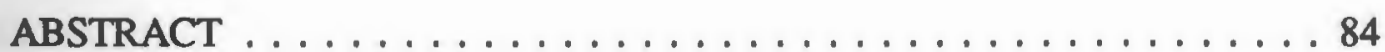

INTRODUCTION $\ldots \ldots \ldots \ldots \ldots \ldots \ldots$

DATA ACQUISITION AND PROCESSING $\ldots \ldots \ldots \ldots$

TECTONIC SETTING AND REGIONAL HISTORY . . . . . . . . . . . 88

WESTERN PACIFIC SEISMIC STRATIGRAPHY . . . . . . . . . . . . 90

ODP Leg 129 Site Review . . . . . . . . . . . . . . . . . 991

DSDP Site Review . . . . . . . . . . . . . . . . 92

SEISMIC OBSERVATIONS . . . . . . . . . . . . . . . . 93

Sediment Velocities . . . . . . . . . . . . . . . . 94

Horizon B . . . . . . . . . . . . . . . . . . 95 
Lower Transparent Unit . . . . . . . . . . . . . . . . . . . . . . 97

Upper Opaque Unit $\ldots \ldots \ldots \ldots \ldots$. . . . . . . . . . . 100

Upper Transparent Unit . . . . . . . . . . . . . . . . . 103

DISCUSSION . . . . . . . . . . . . . . . . . . . . . . . 104

Basinwide Distribution of Sediments Recovered During ODP Leg

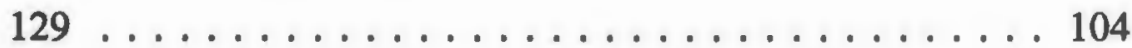

Tertiary Turbidites of the EMB . . . . . . . . . . . . . . . 104

Cretaceous Turbidites in the East Mariana Basin . . . . . . . . . 109

Ogasawara Fracture Zone and Flexural Moat . . . . . . . . . . 110

Correlations between Site 800 \& Site 801 Pigafetta Basin . . . . . . 114

Plate Motion and Seismic Stratigraphy . . . . . . . . . . . . . 116

CONCLUSIONS . . . . . . . . . . . . . . . . . . . . . . . 119

ACKNOWLEDGEMENT . . . . . . . . . . . . . . . . . . 120

FIGURES . . . . . . . . . . . . . . . . . . . . . . . . 122

REFERENCES . . . . . . . . . . . . . . . . . . . 145

MANUSCRIPT III: Comparison of Laboratory and Logging Data from

Leg 129 and the Inversion of Logs to Determine Lithology . . . . . . . . . . . 156

ABSTRACT . . . . . . . . . . . . . . . . . . . . . 157

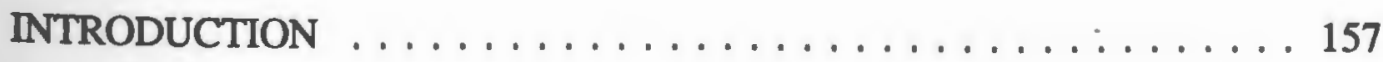

Sediment drilled and cored during Leg $129 \ldots \ldots \ldots \ldots$. . . . . . 158 
Biased Sampling . . . . . . . . . . . . . . . . . . . . . . . 160

EXPERIMENTAL METHODS . . . . . . . . . . . . . . . . . 161

Physical properties rebound corrections . . . . . . . . 165

LOGGING AND LABORATORY PHYSICAL PROPERTIES DATA . . . . 166

Mean Properties . . . . . . . . . . . . . . . . . . 169

Comparison of borehole, laboratory and seismic interval velocities . . . 171

Comparison of $\log$ and laboratory geochemical data $\ldots \ldots \ldots 172$

INVERSION OF LOGS FOR LITHOLOGY . . . . . . . . . . . . . . . . 173

Characterization of lithotypes $\ldots \ldots \ldots \ldots \ldots \ldots$

Stability of the lithotype model . . . . . . . . . . . . . . . . 179

Error Analysis $\ldots \ldots \ldots \ldots \ldots \ldots \ldots \ldots$

Lithotype inversions from Sites 800,801 , and $802 \ldots \ldots \ldots 2$

DISCUSSION AND SUMMARY $\ldots \ldots \ldots \ldots \ldots \ldots$. . . . . . . . . 185

ACKNOWLEDGEMENT . . . . . . . . . . . . . . . . . . . . . 187

TABLES AND FIGURES $\ldots \ldots \ldots \ldots \ldots \ldots$

REFERENCES ......................... 228

APPENDIX A -

Models of Lithospheric Flexure in the EMB and PB . . . . . . . . . . 232

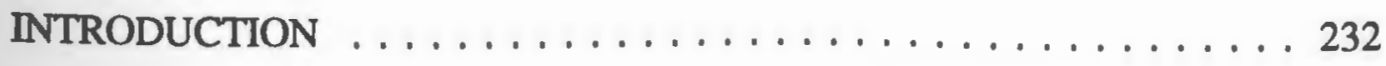


OGASAWARA FRACTURE ZONE AND

MAGELLAN FLEXURAL MOAT $\ldots \ldots \ldots \ldots \ldots \ldots \ldots \ldots \ldots$

Important Observations . . . . . . . . . . . . . . 233

FLEXURAL MODELS . . . . . . . . . . . . . . . . . . 234

Algorithm for calculation of flexural models . . . . . . . . 234

Results . . . . . . . . . . . . . . . . . . . 237

INTERPRETATION . . . . . . . . . . . . . . . . . . . . . . 239

Implications for the observation of flexure of Horizon B . . . . . . . 241

CONCLUSIONS $\ldots \ldots \ldots \ldots \ldots \ldots \ldots \ldots \ldots \ldots \ldots \ldots . \ldots \ldots$

BIBLIOGRAPHY . . . . . . . . . . . . . . . . . . . 257 


\section{LIST OF TABLES}

MANUSCRIPT I: Cretaceous volcanic sequences and Jurassic oceanic crust in the

East Mariana and Pigafetta Basins of the western Pacific

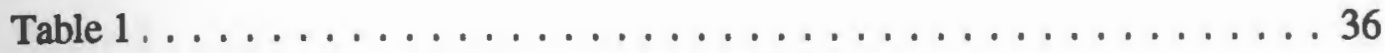

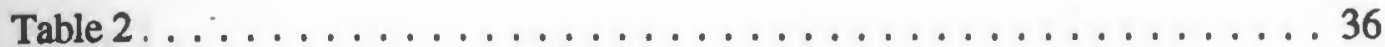

MANUSCRIPT III: Comparison of Laboratory and Logging Data from

Leg 129 and the Inversion of Logs to Determine Lithology

Table $1 \ldots \ldots$. . . . . . . . . . . . . . . . . . . . . . . . . . . 189

Table $2 \ldots \ldots \ldots \ldots \ldots \ldots \ldots \ldots$. . . . . . . . . . . . . . . 189 


\section{LIST OF FIGURES}

MANUSCRIPT I: Cretaceous volcanic sequences and Jurassic oceanic crust in the

East Mariana and Pigafetta Basins of the western Pacific

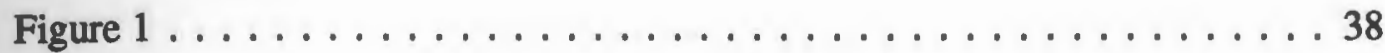

Figure $2 \ldots \ldots \ldots \ldots \ldots \ldots \ldots \ldots \ldots \ldots \ldots \ldots \ldots \ldots \ldots \ldots \ldots \ldots$

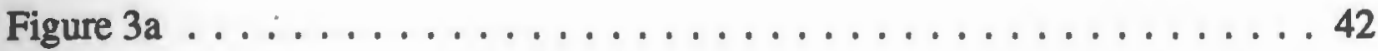

Figure $3 b \ldots \ldots \ldots \ldots \ldots \ldots \ldots \ldots \ldots \ldots \ldots \ldots$

Figure $4 \ldots \ldots \ldots \ldots \ldots \ldots \ldots \ldots \ldots \ldots \ldots \ldots \ldots \ldots \ldots \ldots$

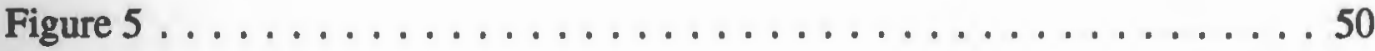

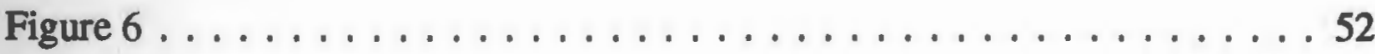

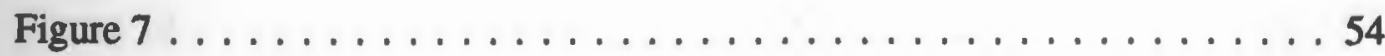

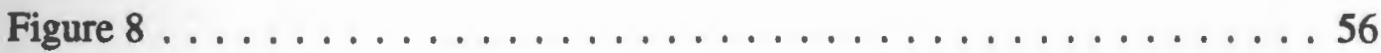

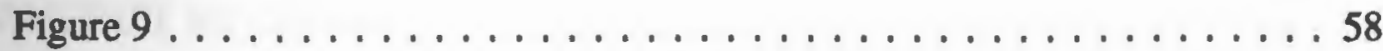

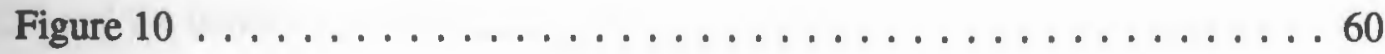

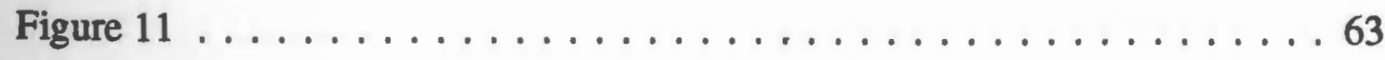

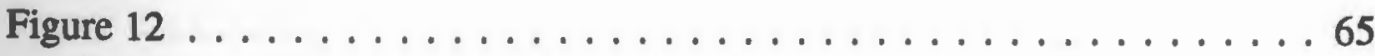

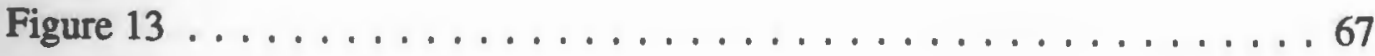


MANUSCRIPT II: Seismic Stratigraphy and Sedimentary History of the

East Mariana and Pigafetta Basins of the western Pacific

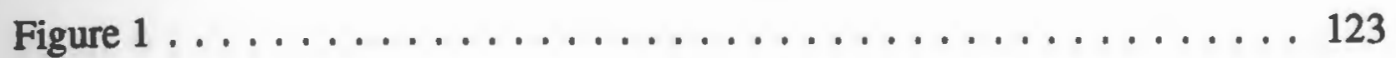

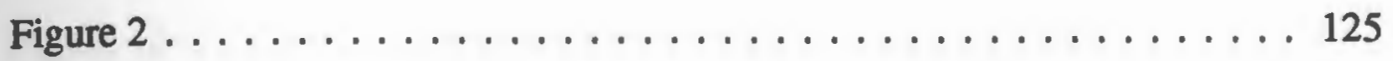

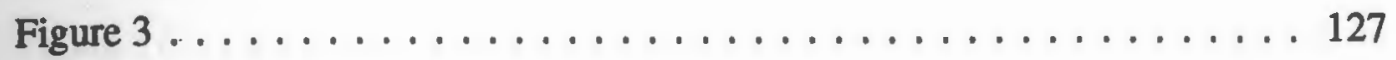

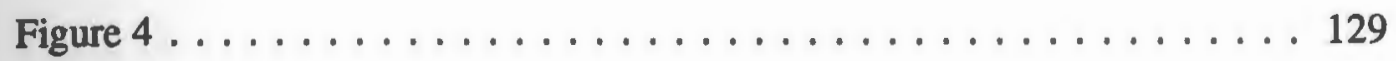

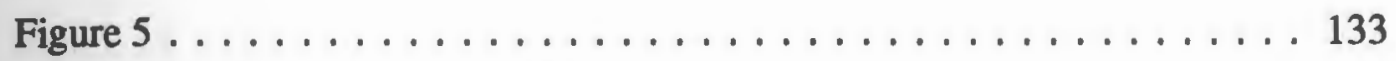

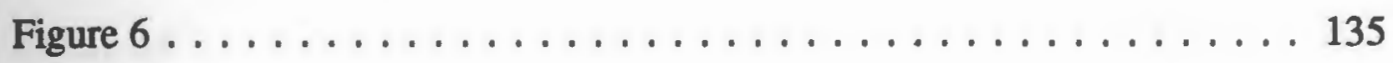

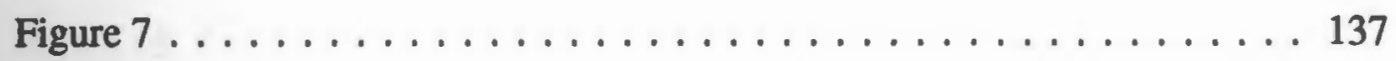

Figure $8 \ldots \ldots \ldots \ldots \ldots \ldots \ldots$

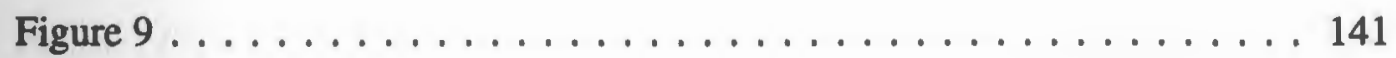

Figure $10 \ldots \ldots \ldots \ldots \ldots \ldots \ldots \ldots$

MANUSCRIPT III: Comparison of Laboratory and Logging Data from

Leg 129 and the Inversion of Logs to Determine Lithology

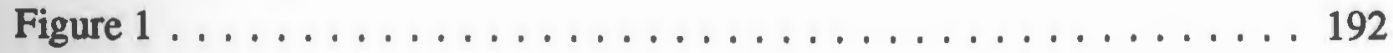

Figure $2 \ldots \ldots \ldots \ldots \ldots \ldots$

Figure $3 \ldots \ldots \ldots \ldots \ldots$

Figure $4 \ldots \ldots \ldots \ldots \ldots \ldots \ldots$

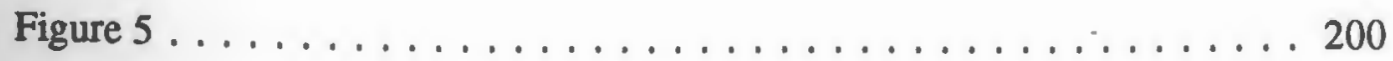

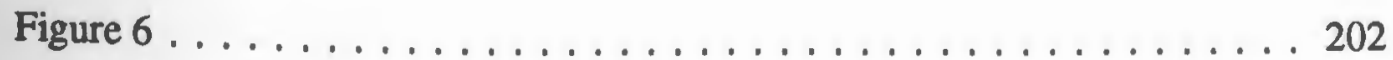




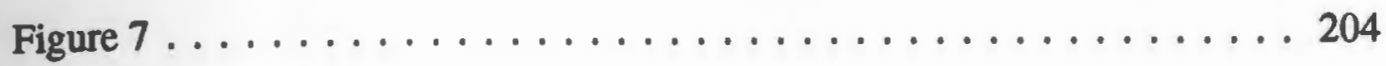

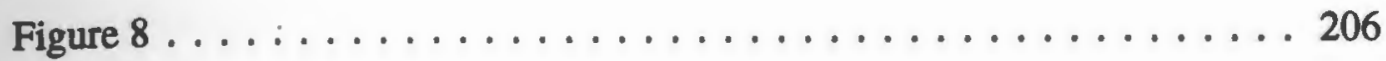

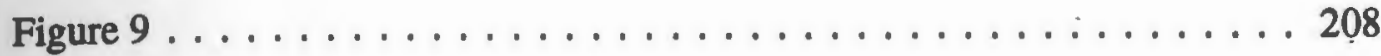

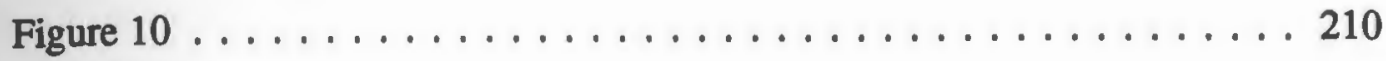

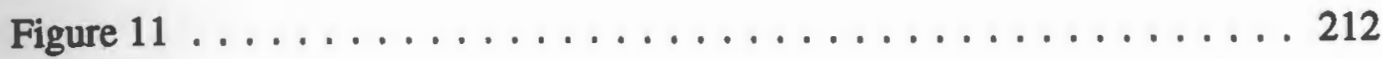

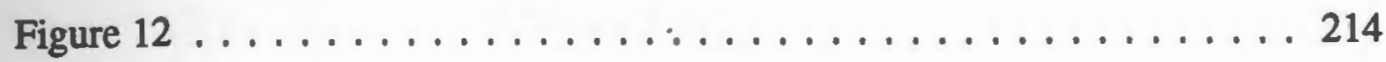

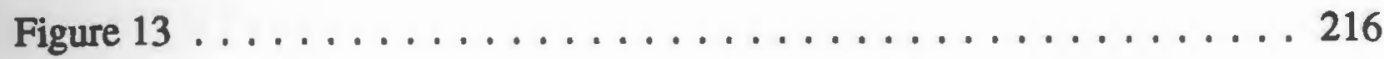

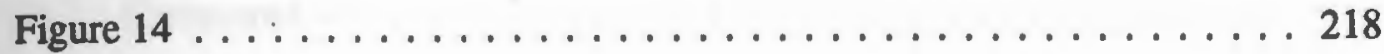

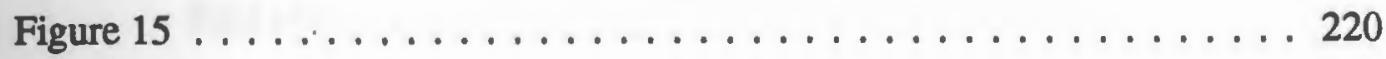

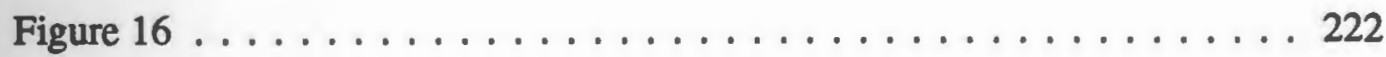

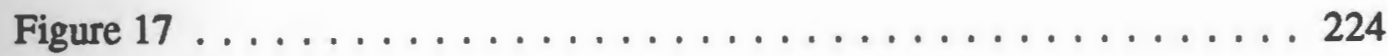

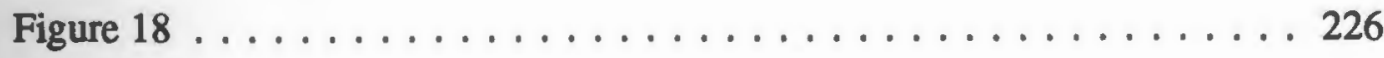

APPENDIX A - Models of Lithospheric Flexure in the EMB and PB

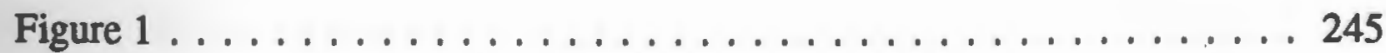

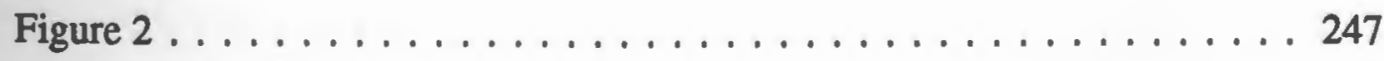

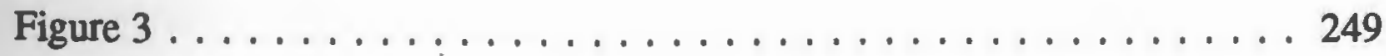

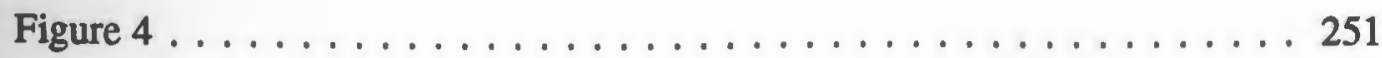

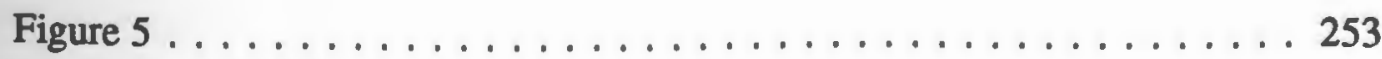

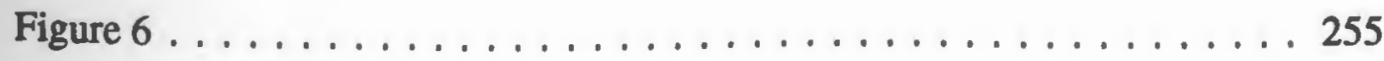




\section{MANUSCRIPT I}

Cretaceous volcanic sequences and Jurassic oceanic crust in the East Mariana and Pigafetta Basins of the western Pacific 


\section{ABSTRACT}

We report the results of the first regional multichannel seismic studies of both the East Mariana and Pigafetta Basins (EMB and PB) of the western Pacific which imaged oceanic crust, mapped the overlying strata and identified a site where Ocean Drilling Program (ODP) Leg 129 recovered Jurassic sediments and oceanic crust for the first time in the Pacific. The calibration of our seismic surveys and the extrapolation of drilling results throughout these oldest Pacific basins indicate that the flat-lying, high-amplitude reflection known as Horizon B corresponds to the top of mid-Cretaceous flows/sills that overlie Jurassic/ Early Cretaceous sediments and oceanic crust throughout an area $500,000 \mathrm{~km}^{2}$ in the EMB and the southeast PB. Seismic refraction and reflection data allow an estimate of $400 \mathrm{~m}$ for the maximum thickness of these flows/sills. A distinct change in the reflection character of Horizon B from flat-lying and "smooth" to higher relief and "rough" observed in the southeast PB marks the change from mid-Cretaceous sills/flows overlying Jurassic oceanic crust to oceanic crust without a massive igneous overburden. Jurassic age oceanic crust and overlying upper Jurassic - lower Cretaceous sediments unquestionably exist at ODP Site 801 in the PB and are intermittently covered by sillsfflows over the $550 \mathrm{~km}$ between Site 801 and Site 800 . The Ogasawara Fracture Zone, which separates the EMB and PB, acted as a locus for mid-Cretaceous volcanic activity as indicated by the coincident alignment and age of seamounts. Intrabasin morphotectonic features other than seamounts which could represent a possible source for the extensive cover of deep sea sills and flows are not obvious on seismic or bathymetric 
records. The ubiquitous presence of mid-to-Late Cretaceous volcanogenic turbidites and widespread occurrences of mid-Cretaceous deep sea sills/flows throughout these basins indicate a pulse in voluminous off-ridge volcanic activity beginning in late Barremian/early Aptian.

\section{INTRODUCTION}

Magnetic anomaly sequences indicate that the world's oldest in situ ocean crust lies centered in the far western Pacific [Larson and Chase, 1972; Hilde et al., 1976; Larson, 1976]. An area, approximately the size of the contiguous United States, enclosed by the M17 isochron is inferred to contain oceanic crust and sediment of Jurassic age (Figure 1). Prior to ODP Leg 129 (Nov-Jan 1989-90), no Jurassic material had been sampled within this region by eight scientific drilling legs since 1969 and numerous dredging expeditions beginning in the 1950's. Instead the oldest material recovered has almost invariably been of mid to Late Cretaceous age and often volcanic in origin. The results from the earliest drilling expeditions led Winterer [1976] to conclude that the recovered basalts probably buried older Early Cretaceous-Jurassic sediments and oceanic crust in the deep portions of western Pacific basins. This hypothesis, represented one aspect of Menard's [1964] "Darwin Rise" which calls for the emplacement of abyssal flood basalts in Cretaceous time in order to account for the burial of abyssal hills surrounding Cretaceous seamounts. 
The mid-Cretaceous volcanism affecting these Jurassic basins manifested itself in several ways. There is the volcanism associated with chains of seamounts and islands such as the Magellan and Marcus-Wake Seamounts which were near or above sealevel by early Aptian ( $-124 \mathrm{Ma})$ [Moberly and Schlanger et al., 1986; Lancelot and Larson et al., 1990; Winterer et al., this volume], the Mid-Pacific Mountains dated at Campanian to Barremian ( 74-132 Ma) [Hamilton, 1956; Winterer and Ewing et al., 1973], the Marshall/Gilbert Seamounts of Campanian to at least Albian age ( $>74$ - $112 \mathrm{Ma}$ ) [Lincoln et al., this volume]. There is also excess mid-plate volcanism in the form of huge oceanic plateaus such as the Ontong-Java Plateau of earliest Aptian age ( $124 \mathrm{Ma})$ [Kroenke and Berger et al., 1991] and finally, the most poorly mapped and dated, mid-plate volcanism in the form of deep sea sills and flows (Nauru Basin - Larson, Schlanger et al., 1981; Central Pacific Basin - Winterer and Ewing et al., 1973; EMB and PB - Lancelot, Larson et al., 1990). The extent of this mid to Late Cretaceous deep sea volcanism, its relationship to numerous seamounts, guyots, underlying sediments, and oceanic crust are of primary concern in this study. Seismic reflection/refraction studies of the EMB and PB presented in this paper show images of oceanic crust, define its seismic structure, map the overlying strata and identified a site where the D/V JOIDES Resolution was able to recover Jurassic oceanic crust during ODP Leg 129 [Abrams et al., 1988; Lancelot and Larson et al., 1990]. The successful completion of Leg 129, resulting in the first and only holes to penetrate igneous basement (mid-Cretaceous basalt or Jurassic oceanic crust) 
in the EMB and PB allowed the calibration of this extensive MCS and SCS data set, the extrapolation of drilling results throughout these basins and comparisons with other western Pacific basins of Jurassic age (e.g. Nauru Basin see Shipley et al., this volume). This basinwide correlation permits a physical and age determination of the flat-lying, high-amplitude reflection(s) known as "Horizon B" or "reverberant layer", observed in extensive areas of the western Pacific including the EMB and PB. These results enable us to place geologic age and volumetric bounds on deep sea volcanism in the EMB and PB and to discuss its relationship with the worldwide occurrence of voluminous midCretaceous volcanism.

\section{DATA ACQUISITION AND PROCESSING}

In November - December 1987 the R/V · Fred H. Moore expedition FM35-12 collected over $3900 \mathrm{~km}$ of multichannel seismic (MCS) data using a 3200-m long receiving array consisting of 96 hydrophone groups each 33.33 meters in length (Figure 3a). The seismic data were sampled at $4 \mathrm{~ms}$, demultiplexed and recorded on a GUS 4200 Marine System. The Moore's seismic source consisted of various combinations of airguns fired at approximately $13.8 \mathrm{MPa}$ (2000 psi) every 20 seconds. The maximum airgun volume achieved was 84.15 liters (5135 in 3 ) but the mean airgun volume during the 17 days of MCS acquisition was 40.65 liters (2481 in ${ }^{3}$ ). Refraction data collected by seven long-range sonobuoys were also digitally recorded during this regional survey 
(sonobuoys 7,8,18,20,21,22,23, Figure 3a, Table 1). The MESOPAC II MCS survey conducted with the N/O Le Suroit during August - September 1989 focused on potential drilling targets first identified on FM35-12 as well as investigating the northern PB within the oldest portion of the M-sequence lineation pattern. Only processed single channel data from MESOPAC II are used in this study. The MESOPAC II expedition also recorded approximately $3900 \mathrm{~km}$ of MCS data using an array of four to six 1.31 liter (80 in3) waterguns fired every 13 seconds during vertical incident profiling and two 16.39 liter (1000 in 3 airguns fired every 31 seconds while digitally recording refraction data from six long-range sonobuoys (sonobuoys $1 \mathrm{~m}, 2 \mathrm{~m}, 3 \mathrm{~m}, 4 \mathrm{~m}, 6 \mathrm{~m}, 8 \mathrm{~m}$, Figure $3 \mathrm{a}$, Table 1 ).

During both cruises the ships maintained a speed of approximately 5 to 6 knots and navigated primarily by transit satellite but also by NAVSTAR global positioning system (GPS) with coverage of approximately 5 hours a day. Shot spacing was calculated for the FM35-12 data using final navigation along individual lines, and for MESOPAC II SCS watergun data was estimated at $40 \mathrm{~m}$ per shot. FM35-12 CDP gathers were created with $66.66-\mathrm{m}$ bin size, 33.33-m hydrophone group spacing with variable shot spacing $(\sim 50 \mathrm{~m} / \mathrm{shot})$ resulting in 100 to 120 fold gathers. Stacking velocities from the seafloor to Horizon B were derived from semblance analysis of four adjacent CDP gathers at selected areas along each line and sub-basement stacking velocities were derived from sonobuoy results. Shot spacing for FM3512 and MESOPAC II sonobuoys was 50-70 m and 80-90 m respectively. 
Sonobuey Methods and Analyses

Travel time-range (T/X) data are used to determine the velocity beneath Horizon $B$, establish its relationship to the top of oceanic crust and define the general crustal structure throughout the EMB and PB. The sonobuoy T/X data from both FM35-12 and MESOPAC II were inverted to a layered velocity-versus-depth model by simply measuring the slopes and intercept times of first-arrival refractions and employing the Tau-p method of Diebold and Stoffa [1981]. This velocity model was used as a starting point for iterative forward modeling of $\mathrm{T} / \mathrm{X}$ data using structures consisting of laterally homogeneous, constant velocity layers and/or constant velocity gradient. Observed $\mathrm{T} / \mathrm{X}$ data were usually modeled within $+/-.02 \mathrm{~s}$, except for longer range mantle arrivals which have uncertainties on the order of .1 s. Amplitudes were not modeled, but relative amplitudes were used to qualitatively assess velocity gradients and to infer the location of critical points on mantle reflections in order to estimate mantle velocities and place further constraints on overlying velocities.

The primary limitations of this modeling technique are: (1) the assumption of one-dimensionality and, (2) the nonuniqueness of any "best fit" model, particularly the inherent ambiguity between variations in layer thickness and velocity in modeling travel time alone. The assumption of one-dimensionality with respect to topography appears justified in this area where the seafloor is essentially flat ( $+1-75 \mathrm{~m}$ maximum) over the $30-40 \mathrm{~km}$ range of these sonobuoys. The highest amplitude sub-bottom reflections are 
most often flat lying but at some locations Horizon B displays up to $150 \mathrm{~m}$ of relief. There is also evidence on some sonobuoys for out-of-plane disturbances and discontinuities in basement structure. Direct wave arrivals were used to calculate ranges assuming a water velocity of $1.54 \mathrm{~km} / \mathrm{s}$ estimated from CTD measurements. Sediment velocities, based on analysis of four contiguous CDP gathers from the $3.3 \mathrm{~km}$-long 96 channel streamer, ranged from 1.6 to $3.0 \mathrm{~km} / \mathrm{sec}$, usually increasing with depth. This range in velocities is also consistent with modeled reflections within the sediment layer. Only one or two of the highest amplitude reflectors within the sediment were matched by velocity contrasts in the model, and sediments were divided into isovelocity layers even though it is recognized that velocity gradients may also occur.

In a few cases (e.g. sonobuoys $1 \mathrm{~m}, 4 \mathrm{~m}, 6 \mathrm{~m}, 22$ ) refracted second arrivals were observed within the reflection hyperbola of the seafloor and sediment and traced to their tangency to the Horizon B sub-bottom reflection (e.g., Figure 10). These continuously curved refractions are indicative of relatively steep velocity gradients and provide constraints on the velocity immediately below Horizon B. These refracted arrivals are continuous with high amplitude first arrivals beyond $7 \mathrm{~km}$ range. In the remaining instances, where first arrival refractions could not be followed to shorter ranges within the seafloor reflection, a single velocity gradient was assumed, resulting in continuously curved modeled refraction arrivals tangent to the Horizon B reflection. The resulting velocities and velocity gradients are characteristic of oceanic layer 2. It was with this 
evidence that high-velocity igneous material was successfully predicted to occur at the depth of the Horizon B reflection at all three ODP Leg 129 Sites.

Oceanic layer 3 is well-defined on many sonobuoys by the weak first arrivals beyond $18-20 \mathrm{~km}$ range (Figure 10 ). The relatively low amplitude of these refractions along with the high-amplitude reflection from the Moho indicate a low velocity gradient typical of oceanic layer 3 (White, 1979; Purdy, 1983). The velocity at the bottom of layer 2-top of layer 3 is constrained by arrivals between $10-20 \mathrm{~km}$ that are modeled as a layer with a small positive velocity gradient overlying a zero gradient layer 3 . The velocity within layer 3 was usually assumed to be continuous with the overlying velocity structure. Wide-angle mantle arrivals were modeled as reflection events from a single discontinuity in velocity at the layer $3 /$ mantle interface. The distinct travel time separation between refracted arrivals from layer 3 (P3) and Moho reflections (PmP) places constraints on the thickness of layer 3, and therefore, total crustal thickness. The velocity and thickness of layer 3 were chosen to best fit the curvature and travel time of the Moho reflection. Reflections from the Moho also appear on FM35-12 CDP data at 1.8 to 2.2 stwt below Horizon B (10.1 - 10.5 stwt) and are used as further constraints on crustal thickness. The underlying mantle velocity is not well constrained by travel time data primarily because most sonobuoys were unable to record arrivals at ranges greater than $\mathbf{3 0}$ $\mathrm{km}$, however upper mantle velocities of $8.2 \mathrm{~km} / \mathrm{s}$ were recorded on ocean bottom seismometers (OBSs) from explosive charges at ranges from 50 to $500 \mathrm{~km}$ in the EMB 
[Asada et al., 1985]. In addition, the observed amplitude build up at 20-22 km range was used to estimate critical distance which required upper mantle velocities between 8.0-8.3 $\mathrm{km} / \mathrm{s}$ for all of the models. Although the top of the Moho is well placed in these models, mantle arrivals over their entire range cannot be matched by a single discontinuity; the travel times in some cases are better fit by models which include a transition zone with a velocity gradient at the base of the crust.

\section{TECTONIC SETTING .}

The bathymetric map of this region (Figure 2) reveals a huge area $\left(\sim 1 \times 10^{6} \mathrm{~km}^{2}\right)$ at depths greater than $5500 \mathrm{~m}$, which we consider the EMB and PB. The EMB is bounded to the west-northwest by the Mariana Trench, to the southwest by the Caroline Ridge and to the northeast by the northwest trending Ogasawara Fracture Zone and Magellan Seamounts [Tamaki et al., 1987; Handschumacher et al., 1988] (Figures 1 and 2). The PB is bounded to the northeast by the Kashima Fracture Zone and Marcus-Wake Seamounts and to the southeast by the Ogasawara Fracture Zone and Magellan Seamounts and extends to the northwest where it terminates at the Bonin Trench.

In this paper age is assigned according to the Harland et al. [1990] geologic time scale. The younger parts of the EMB toward the northwest are believed to be Kimmeridgian to Oxfordian (anomalies M22 to M25, 150 - $155 \mathrm{Ma}$ ) and just seaward of the Bonin Trench the PB may be as young as Valanginian-Tithonian (M13-M17 139- 
$145 \mathrm{Ma}$ ). Within our survey area the central parts of these basins are extrapolated to be Oxfordian to Callovian (anomalies M29 to M36 - 157-161 Ma) and toward the southeast, within the so-called Jurassic magnetic quiet zone (JQZ), the age of the crust may be as old as Bathonian to Bajocian (Middle Jurassic, 161-174 Ma) [Tamaki et al.,1987; Handschumacher et al., 1988; Nakanishi et al., 1989; and Nakanishi et al., in press]. These inferences were confirmed by the $166.8+/-4.5 \mathrm{~m} . y$. age and geochemical attributes of the tholeiitic basalts recovered at Site 801 in the JQZ that indicate they represent Jurassic oceanic crust [Floyd et al., 1991; Pringle, in press; Castillo et al., in press]. The exact nature of the low field uncorrelated magnetic anomalies in the JQZ remains unknown, but the equivalent time interval in land sections was found to be a period of extremely frequent magnetic reversals by Steiner et al. [1987]. A crustal age of $\sim 167 \mathrm{Ma}$ at Site 801 results in pre-M25 half-spreading rates of approximately $80 \mathrm{~mm} / \mathrm{yr}$ assuming constant rates of spreading and an M25 date of $155 \mathrm{Ma}$ [Harland et al.,1990]. This spreading rate is comparable to the fastest half-spreading rates presently documented on the East Pacific Rise [80 - $90 \mathrm{~mm} / \mathrm{yr}$ Macdonald, 1982].

\section{PREVIOUS STUDIES}

\section{Toetern Pacific Seismic Stratigraphy}

The seismic stratigraphy of large portions of the western Pacific including the PB and EMB consists of four units originally defined by Ewing et al. [1968]: (1) an upper 
transparent layer, (2) an upper opaque layer, (3) a lower transparent layer, and (4) Horizon B. This paper will concentrate primarily on the Horizon B reflection and subHorizon B velocity structure throughout the EMB and PB. The stratigraphy overlying Horizon B is discussed in Abrams et al. [in press].

Horizon B has been referred to as the "deep opaque layer" [Heezen et al., 1973], as the "reverberant layer" by Houtz et al. [1970] and Houtz and Ludwig [1979], and as "acoustic basement". Horizon B has been characterized from observations of SCS analog airgun profiles by the presence of a prominent zone of flat-lying ("smooth"), high-amplitude, and closely spaced reflections. Houtz and Ludwig [1979] completed an extensive review of the areal extent, thickness and velocity of the reverberant layer/Horizon B seismic facies throughout the western Pacific and speculated (as did Ewing et a1., 1968) that this layer is composed of highly stratified calcareous or redeposited volcaniclastic sediments that overlie oceanic crust. Drilling in the western Pacific prior to Leg 129 has demonstrated that Horizon B generally is produced by the impedance contrast between sediments and volcanic sills or flows (e.g. Nauru BasinDSDP Site 462) and, in some cases, the sediment /oceanic crust interface in areas interpreted to contain particularly smooth crust. It is now recognized that the reverberant nature of Horizon B in airgun profiles is usually the result of a trailing bubble pulse oscillation reflecting from a high impedance boundary implying that the thickness or stratification inferred for this layer is an artifact of the airgun source and gain setting in the 
analog recording [Shipley et al., 1983]. This characteristic of the airgun source is now routinely compensated for through the use of tuned airgun arrays and/or deconvolution techniques and the use of waterguns (e.g., MESOPAC II), which provide a more implosive and bubble pulse-free source signature resulting in a high-resolution record with less processing effort [Hutchinson and Detrick, 1984].

\section{Leg 129 Site Review}

Sites drilled during ODP Leg 129 . penetrated and recovered material correlated to all four general seismic units of Ewing et al. [1968], including Horizon B. The seismic stratigraphy at ODP Leg 129 Sites 800,801 , and 802 is summarized in Figure 4 (from Abrams et al. in press).

Horizon B at all three Leg 129 Sites corresponds to the top of intrusive and/or extrusive dolerite/basalt at approximately $500 \mathrm{mbsf}$. In the northwest PB, at Site 800 , dolerite sills radiometrically dated at $126.1+/-0.6 \mathrm{Ma}$ intrude Berriasian ( $140-145 \mathrm{Ma})$ pelagic sediment [Lancelot and Larson et al., 1990; Pringle, in press] . Oceanic crust at Site 800 , predicted to be $\sim 160 \mathrm{Ma}$ (M33), was not recovered. Horizon B at Site 802 , in the central EMB, also correlates to a mid-Cretaceous volcanic surface. At this location pillow and flow basalts dated at 114.6 $+/-3.2 \mathrm{Ma}$ were recovered in an area where oceanic crust is predicted to be $>161 \mathrm{Ma}$ (M35). Site 801 , in the JQZ of the PB is the only location where oceanic crust was recovered. The radiometric age $(166.8+/-4.5 \mathrm{Ma}$, Middle Jurassic) of the tholeiitic basalt flows is almost exactly that predicted from linear 
extrapolation of post M25 magnetic lineations. Finally, thick sequences of mid to Late Cretaceous volcanogenic turbidites were penetrated at all three Leg 129 sites as well as at DSDP Site 585, indicating that edifice building and emplacement of deep sea sills/flows (e.g., Sites 800, 802) were essentially synchronous [Lancelot and Larson et al., 1990] .

\section{SEISMIC OBSERVATIONS AND RESULTS}

The results of our regional seismic profiles are illustrated in three cross sections (Figure 5) accompanied by several key seismic reflection examples. The cross sections were created by digitizing distinctive reflection surfaces which seemed to maintain unique characteristics (i.e. seismic facies) over basinwide distances. The selected horizons include the seafloor, the shallowest abundant chert/porcellanite/clay or chert/chalk, midCretaceous age basaltic sills/flows and/or the top of Jurassic age oceanic crust. The lithofacies significance of these distinct horizons and the intervals which they bound are based on the lithologies recovered during ODP Leg 129 as well as DSDP Sites 61,199 and 585 [Abrams et al., in press].

\section{Deneral Characterization of Horizon B}

Horizon B is associated with the onset of high velocities $(>3.6 \mathrm{~km} / \mathrm{s}$ see Sonobuoy Analysis section), and we believe it is often comparable in acoustic character to the unusually smooth basement observed in parts of the western North Atlantic and Caribbean Basin that was designated as Horizon B" [Ewing et al., 1967; Edgar, Saunders 
et al.,1973; Houtz and Ludwig, 1977]. Its reflection character and stratigraphic position determines whether Horizon B is interpreted as the top of sills/flows overprinting true oceanic crust, or as Jurassic age oceanic crust with no such massive igneous overburden.

In general Horizon B can be characterized by two end members; 1) a relatively highrelief, (50-100m over 10's of $\mathbf{k m s ) , ~ l o w e r ~ r e f l e c t i o n ~ a m p l i t u d e , ~ d i f f r a c t i v e ~ ( " r o u g h " ) ~}$ surface which always appears as acoustic basement and is interpreted as the top of oceanic crust, 2) a flat-lying, high reflection amplitude, semi-continuous surface which often appears non-diffractive ("smooth"), does not necessarily appear as acoustic basement and is interpreted as sills/flows overlying oceanic crust. A map view of the acoustic character of Horizon B and its interpretation is presented along track in Figure 3b. Figure 3b indicates that there are extensive areas in the northwest PB where the acoustic character does not clearly fall within the above defined modes and/or these end member characteristics alternate over distances of only 10 's of kms and as a result these areas have been more tentatively interpreted as the top of oceanic crust with possible sill/flow overburden.

\section{Forizon $B$ in The East Mariana Basin}

In the majority of the EMB, Horizon B (heavy line in Figure 5) is high-amplitude, flat-lying, continuous and "smooth" (e.g. mode 2). There are, however, several significant variations in its character. In restricted areas of the EMB Horizon B deepens slightly and becomes noticeably more diffractive (but still flat-lying), for example, at Site 
802 where Horizon B corresponds to pillow and flow basalt (Figure $4 c$ and 6). In other instances Horizon B appears to be divided by and contiguous with zones of poor reflectivity giving the appearance of "windows" through this ubiquitous horizon. A similar geometry is evident along the eastern EMB margin where Horizon B appears as a series of slabs which are offset laterally as well as vertically with no corresponding offset of the overlying sediment (Figure 8). To the south of Site 802, Horizon B appears continuous as it rises gradually from $6000 \mathrm{~m}$ to the $5000 \mathrm{~m}$ contour which marks the base of the Caroline seamounts, atolls and guyots (Figures 2,7 ). The continuity of the gently rising Horizon B is only disrupted near the base of the Caroline Ridge by an offset (150 $\mathrm{msec}$ ) which is not matched by offsets in the overlying reflections.

Two seismic profiles crossing the eastern margin of the EMB (Figures $5 \mathrm{~b}$ and $5 \mathrm{c}$ ) reveal the deepening of Horizon B from approximately $300-500 \mathrm{mbsf}(8.3-8.5 \mathrm{stwt})$ to the west within the EMB to over $1150 \mathrm{mbsf}$ (>9.2 stwt) where the southern profile crosses DSDP Site 585. Correlations of seismic stratigraphy with drilling results from Site 585 indicate that the total depth reached at this site corresponds to a zone of relatively high-amplitude conformable reflections at approximately 8.9 to 9.0 stwt [Moberly,Schlanger et al., 1986, Abrams et al., in press] and may correlate with the wellcemented, Aptian age volcaniclastic turbidites and debris flows lying approximately $260 \mathrm{~m}$ above the high-velocity basement at 9.2 stwt as determined by sonobuoy 20 (Figure 13A). In this area there is no well-developed flat-lying, high-amplitude Horizon B observed. 
Finally, there are also sub-Horizon B reflection events observed in certain areas of the EMB. The suppression of bubble pulse multiples from Horizon B on processed FM35-12 MCS data revealed weaker, discontinuous reflections approximately $100-150 \mathrm{~ms}$ below Horizon B. The identification of these weak reflections, which are often identical in shape to the overlying Horizon $\mathrm{B}$, as primary reflection interfaces rather than bubble pulse or interbed multiples is strengthened by isolated instances where these weak reflections display significant relief independent of flat-lying Horizon B and overlying sediments. A clear example of this type of reflection geometry is displayed in Figure 7.

The flat-lying, typically smooth character of Horizon B in the EMB and southeastern PB does not appear to change from profiles shot perpendicular to those shot parallel to magnetic lineations. This indicates that any abyssal hill morphology is muted, absent or buried and suggests that this is not the upper surface of oceanic crust. In addition, the Aptian age (124.5-112 Ma) of sediment overlying 114 m.y. old extrusive basalt is approximately 50 m.y. younger than predicted from magnetic lineation correlations which had so successfully predicted the basement age at Site 801 (e.g. $~-167$ Ma) [Tamaki et al., 1987; Lancelot and Larson et al., 1990; Pringle, in press]. Thus, throughout the EMB, including the Caroline Ridge, Horizon B is interpreted as the top of mid-Cretaceous flows and/or sills (probably late Barremian - Aptian) which overlie Jurassic oceanic crust. The weak sub-Horizon B reflections, though not penetrated at ODP Site 802 , are interpreted as the top of oceanic crust. 


\section{Horizon $B$ in The Pigafetta Basin}

In the southeastern $\mathrm{PB}$, Horizon $\mathrm{B}$ is semi-continuous, flat-lying and shallow (250300 mbsf, 7.9-8.0 stwt). It is observed to monotonically deepen (400-480 mbsf) to the northwest becoming distinctly more diffractive (rougher), undulating, and lower in reflection amplitude beginning approximately $130 \mathrm{~km}$ southeast of, and including ODP Site 801 (Figures 5a and 9). This change in acoustic character from flat-lying to high relief appears as a distinct boundary rather than an extended transition zone on our southeast to northwest seismic profiles and is designated as the "Rough/Smooth Boundary" (Figure 3,9). This boundary was located along profiles running southeast to northwest where flat-lying, semi-continuous Horizon B is first disrupted by a distinctly higher relief (perhaps tectonized) surface. To the northwest of the rough/smooth boundary, Horizon B displays a variety of reflection characteristics, which are superimposed upon a subtle, longer wavelength Horizon B surface (Figure 5a). Horizon B at Site 801 appears as a rough, undulating horizon that results primarily from a large impedance contrast between the Callovian/Bathonian aged radiolarite clays and the top of interbedded chert/basalt and hydrothermal deposits which unquestionably represent the top of Jurassic oceanic crust (Figure 4b) [Lancelot and Larson et al., 1990]. In the areas to the southeast of Site 801 where Horizon B becomes flat-lying, "smooth" and shallow, and the overlying seismically transparent layer thins, sills and/or flows that are significantly younger (probably Aptian) than those recovered at Site 801 are expected to overlie oceanic 
crust (Figure 9 right side, 3b). Further to the northwest, Horizon B appears tectonized, sometimes exhibiting smooth, block faulted slabs having an apparent dip to the northwest. Within the area of correlated magnetic lineations M29-M36 (Figures 1 and 2), Horizon B rarely appears similar to the rough, undulating basement horizon observed in the vicinity of ODP Site 801 (Figure 4b; Figure 9 left side), however, it is not characterized by the extended areas of flat-lying, high-amplitude and "smooth" reflections observed in the southeast PB and the majority of the EMB. Specifically, there are no examples where Horizon B appears discontinuous and/or vertically offset as in the EMB (e.g. Figure 8). Horizon B at Site 800 correlates to the top of dolerite sills intruding Berriasian age [140-145 Ma] radiolarite clays. Although drilling at Site 800 penetrated through a thick mid-Cretaceous volcaniclastic sediment unit and reached earliest Cretaceous pelagic sediments, Horizon B here does not represent oceanic crust because of the age ( $126 \mathrm{Ma}$, Pringle, in press), thickness and obvious intrusive character of the dolerite, and because the oldest sediments would be expected to be Oxfordian in age ( 160 Ma, M33).

The Horizon B reflections can be followed over the $550 \mathrm{~km}$ separating Sites 800 and 801. Results from these sites suggest that this horizon corresponds to the top of Jurassic oceanic crust where it appears particularly high relief, undulating, lower in reflection amplitude, and diffractive. It corresponds to a thin, (approximately 100-400 m) mid-Cretaceous igneous unit overlying oceanic crust where it appears flat, high amplitude, 
"smooth" and slablike. The actual thickness of the mid-Cretaceous sills and flows, however, is uncertain, and aspects of this determination are discussed in the following section.

\section{Sill/Elow/Sediment Thickness}

To establish the relationship between Horizon B and the top of oceanic crust by focusing on evidence for sills/flows overlying oceanic layer 2 , we first describe the area in the PB where Horizon B correlates to the top of Jurassic age oceanic crust. We then compare the velocity-depth profiles and record sections from this area to areas in the PB and EMB where Horizon B correlates to the top of mid-Cretaceous sills and/or flows.

In Figure 11 and Table 1 we show Vp versus depth functions obtained from 13 sonobuoys. The velocity-depth functions below the seafloor are given in terms of a series of constant velocity gradient layers. Figure 11a indicates that velocities and/or velocity gradients characteristic of oceanic crust begin at or just below the dominant Horizon B reflection, imaged regionally at 300 to $600 \mathrm{mbsf}$. Sonobuoy 20 , shot over DSDP Site 585 , is the one exception to this relationship and indicates that approximately $1150 \mathrm{~m}$ of sediment overlie high-velocity basement in the area that we identify as the Ogasawara Fracture Zone (Figures 2, 5).

Sonobuoys $4 \mathrm{~m}, 6 \mathrm{~m}$ and 22 (Figures 10 and $11 \mathrm{~b}$ ) within $45-95 \mathrm{~km}$ of ODP Site 801 provide the best constraints on crustal structure, not only because a complete suite of arrivals are observed, but also because Site 801 is the single location where Jurassic 
oceanic crust undoubtedly exists without any younger igneous overburden. Velocitydepth functions of these three sonobuoys are shown separately in Figure 11b. The normal-incidence two-way reflection time through this structure agrees to better than $0.1 \mathrm{~s}$ with the location of the Moho reflection observed on FM35-12 MCS profiles collected during the acquisition of sonobuoy 22 (Figure 12). The total crustal thickness is $7.2 \mathrm{~km}$ (2.22 stwt), overlain by an average $410 \mathrm{~m}$ of sediment. The remaining sonobuoys are divided into groups representative of distinct areas of the EMB and PB (Figures 2 and 3a location). Layer thicknesses derived from these sonobuoys are defined and listed in Table 2.

Analysis of T/X data along with the drilling results from ODP Sites 800,801 and 802 clearly establish that Horizon B represents the top of high velocity $(>3.6 \mathrm{~km} / \mathrm{s})$, massive igneous material throughout these basins. The greatest limitation of this travel time-range study is that in those cases where short range refracted second arrivals in the critical range $(5-8 \mathrm{~km})$ are obscured by seafloor and Horizon B reflections it is impossible to distinguish between a variety of probable velocity structures (resolvable at seismic wavelengths) between the Horizon B reflection and the structure revealed by longer range (deeper) refracted arrivals. The necessity of assuming or calculating a velocity for the uppermost crust (layer $2 \mathrm{a}, \mathrm{b}$ or in this case the layer beneath Horizon $\mathrm{B}$ ) because of the lack of observable refracted arrivals is well documented [Ewing and Purdy 1982]. The problem here is that other evidence indicates that sills/flows and sediment actually overlie 
Jurassic age oceanic crust (layer 2) in the majority of the EMB, and in the PB southeast of the rough-smooth boundary. Modeling the structure immediately below Horizon B as a single velocity gradient in these areas of the EMB and PB in effect includes midCretaceous sillsflows and sediments as part of layer 2.

Velocity-depth structures calculated in this way fall within the wide bounds defining normal oceanic crust (Figure 11c; Houtz and Ewing, 1973; Spuditch and Orcutt, 1980; White, 1984) and total crustal thicknesses do not appear significantly different between the EMB and PB (Table 2). Assuming layer 2 thicknesses determined from sonobuoys 22 , $4 \mathrm{~m}$ and $6 \mathrm{~m}$ are representative of Jurassic age oceanic crust in this area implies that the midCretaceous age sill/flow/sediment complex in the EMB may range in thickness from 0 to approximately $1 \mathrm{~km}$ depending on how layer 2 is defined (e.g. table $2,1.7$ to $2.85 \mathrm{~km}$ vs 1.3 to $1.7 \mathrm{~km}$ ). Thus, there is no seismically resolvable, systematic differences in crustal velocities and thicknesses between areas where mid-Cretaceous sills/flows are present and where they are absent. This observation is significant when compared to anomalously thick crust observed in portions of other basins where a smooth basement reflection (Horizon $\mathrm{B}$ or $\mathrm{B}^{n}$ ) corresponds to the surface of younger (mid-Late Cretaceous) sills/flows throughout an area predicted to contain Jurassic age sediment and oceanic crust such as the Nauru Basin (western Pacific Figure 1) and basins of the Caribbean Sea [Edgar et al., 1973; Larson, Schlanger et al., 1981; Wipperman et al., 1981; Diebold et al., 1981]. 
The results from sonobuoys in the EMB, however, provide further support for the presence of sills/flows overlying sediment and oceanic crust. In two instances (sonobuoys 8 and 18) low-amplitude refracted arrivals of limited range appear tangent to or slightly below the Horizon B reflection (Figure 13a,b, arrival labeled "sill"). These weak but distinct events extend as first arrivals that overlie the higher amplitude, continuous refractions that characterize normal oceanic crust. These arrivals have a phase velocity of approximately $5.3 \mathrm{~km} / \mathrm{s}$ and show a rapid decay in amplitude with range. Such observations are consistent with the existence of a high-velocity igneous layer capping lower velocity sediments which overlie oceanic crust. Shallow "sill" refractions are not observed on any sonobuoy records from the PB (e.g., Sites 800 and 801; compare Figures $10 \mathrm{~b}$ and $13 \mathrm{~b}$ ). We note that the velocity-depth solutions given in Table 1 were derived by matching the stronger, more coherent and longer range arrivals that occur approximately $0.15 \mathrm{sec}$ below the weaker first arrivals labeled "sill". This was done primarily because ray theory cannot simultaneously match both sets of arrivals over the same range when the velocity of the shallow first arrival is greater than that of the deeper second arrival.

In order to be imaged as a separate unit, the silvflow sediment complex must create an impedance contrast with layer 2 at least $1 / 4$ of a seismic wavelength in thickness $(>50-125 \mathrm{~m}$ ). If one is looking for a velocity discontinuity representing the base of Blll/flow/sediment and top of layer 2 then the most appropriate factor to examine is the 
presence or absence of reflections. In the EMB, low-amplitude, discontinuous reflections observed 0.1-0.15 stwt below Horizon B may be due to the impedance contrast between Jurassic oceanic crust and pre-Aptian (>124.5 Ma) pelagic sediment with Aptian sills/ flows. The velocity at the top of this interval is approximately $5.3 \mathrm{~km} / \mathrm{s}$ as revealed by weak, short-range refractions observed on sonobuoys in the EMB (Figure 13a,b) and approximately $5.8 \mathrm{~km} / \mathrm{s}$ as determined by the average velocity of basalt samples from Site 802 Lancelot and Larson et al. [1990]. Assuming an average velocity of $5.3 \mathrm{~km} / \mathrm{s}$ for the interval between the top of Horizon B and top of the weak sub-Horizon B reflections (top of oceanic crust) results in a maximum thickness of $265-398 \mathrm{~m}$ for the Aptian flows/sills and interbedded sediment.

\section{DISCUSSION}

The thickness of mid-Cretaceous igneous overburden and pre-mid-Cretaceous sediments in the EMB and portions of the PB is estimated at $100-400 \mathrm{~m}$ based on the following corroborative evidence.

1) The similarities of upper crustal velocity structure and total crustal thicknesses derived from $T / X$ sonobuoy data throughout the PB and EMB indicate a maximum thickness of approximately $1 \mathrm{~km}$. However, based on weak sub-Horizon B reflections, the maximum thickness for this unit is better estimated at $400 \mathrm{~m}$, as discussed above.

2) Synthetic seismograms created from a simplified impedance structure at Site 802 , 
which employ the source waveform from FM35-12 and Mesopac II, indicate that a minimum sub-Horizon B layer thickness of $200 \mathrm{~m}$ can be resolved, that is the top of Horizon B and the top of oceanic crust appear as two separate reflection events. We interpret the discontinuous and low amplitude nature of reflections from the top of oceanic crust as due to the vertical resolution of the seismic signal and, to a lesser degree, the lack of seismic energy penetration resulting from the high reflection coefficient of Horizon B. In the majority of the EMB and PB the thickness of the sill/flow/sediment complex above oceanic crust is on the order of our ability to easily resolve seismically (e.g. $\sim 200 \mathrm{~m}$ ). When this layer thins, the already weak reflection from the top of oceanic crust merges with and becomes part of an interference pattern created by closely spaced impedance contrasts that begin with Horizon B. Furthermore, we expect that only 100 to $150 \mathrm{~m}$ of sediments are intruded and or capped by sills/flows at Sites 800 and 802 , respectively, assuming that a sedimentary section comparable to Site 801 is representative of the PB and EMB for sediment deposited prior to the onset mid-Cretaceous volcanism.

3) The relatively high-relief, diffractive reflection associated with the top of oceanic crust at Site 801 is observed to extend semi-continuously to the northwest where the basement horizon alternates between rough, high-relief (e.g. Site 801) and relatively smooth and flatlying (e.g. sills/flows) while remaining at the same depth. This type of reflection geometry is inconsistent with a widespread, thick overburden of igneous material.

In the EMB and PB mid-Cretaceous (probably Aptian) sills/flows are identified 
along more than $4000 \mathrm{~km}$ of trackline throughout an area of approximately $500,000 \mathrm{~km}^{2}$ (Figure 3b). Assuming a maximum thickness of $500 \mathrm{~m}$ allows a volume estimate for deep sea mid-Cretaceous sills/flows in the EMB/PB of $\sim 0.25 \times 10^{6} \mathrm{~km}^{3}$. Although arealy extensive, the estimated volume is small compared to volume estimates for well-known flood basalts such as the Deccan Traps $\left(-2 \times 10^{6} \mathrm{~km}^{3}\right.$ - Courtillot et al., 1987) and to large oceanic plateaus such as Ontong-Java ( $50 \times 10^{6} \mathrm{~km}^{3}$ - Schubert and Sandwell, 1989).

\section{Tectonic Setting and Source of Deep Sea Volcanism}

The MCS coverage of the EMB and PB along with bathymetry provide additional constraints on the morphotectonic expression of possible volcanic sources. The geometry of the "Rough/Smooth Boundary" in the PB and the continuation of the mid-Cretaceous igneous surface up onto the Caroline Ridge south of the EMB indicate that sources for these semi-continuous sills/flows extend to the south. Basalts recovered in the EMB are similar in age and in major, trace and isotopic element composition to basalts recovered in the Nauru Basin and the Ontong-Java Plateau (Figure 1), all showing strong affinities to MORB with a variably enriched mantle I (EM I) deep mantle source component [Castillo and Carlson, 1990; Mahoney and Tarduno, 1990; Castillo and Pringle, 1991; Tarduno et al., 1991]. These authors have speculated that the Nauru Basin and EMB were both sites of deep sea volcanism associated with the rapid formation of the Ontong-Java Plateau. Our seismic observations are consistent with this notion and indicate that the southeast PB 
was similarly affected. Northwest of the "Rough-Smooth Boundary" (e.g., Sites 800 and 801) mid-Cretaceous deep sea volcanism is much more restricted, being associated with individual seamounts and or seamount provinces as indicated by the comparable ages and distinct geochemistries of both the sills penetrated at Site 800 and samples dredged from Himu and Golden Dragon seamounts (Figures 2 and 3b) [Smith et al., 1989; Castillo and Pringle, 1991, Pringle, 1992; Castillo et al., in press]. Continuity between these types of volcanic structures (seamounts, plateau, and deep sea flood basalts) is not observed seismically, so any inference of genetic relationships requires geochemical comparisons. However, the syncronicity in emplacement of these volcanic constructs with increased world-wide spreading rates (increased total crustal production) and the onset of the Cretaceous Normal Polarity Superchron ( $124 \mathrm{Ma})$ is clear and may be the consequence of sudden heat and material transfer from the core/mantle boundary in the form of a rising plume resulting in excess mantle melt generation (Larson, 1991).

The local volcanic sources and actual mode of emplacement of laterally extensive deep sea igneous provinces is still unknown. The most probable tectonically-controlled source location for mid-Cretaceous volcanism is the Ogasawara Fracture Zone because of its association with large mid-Cretaceous seamounts. Magnetic anomalies M22-M36 are offset approximately 500-600 km left-laterally from the EMB to the PB and are separated by a region approximately $300 \mathrm{~km}$ wide (Figures 2,3). The Ogasawara Fracture Zone that offsets these lineations lies somewhere within this broad zone, the two seismic 
profiles across this region indicate that the fracture zone lies along the northeastern margin of the EMB (e.g. southwestern dashed line in Figures 2,3) where the depth to seafloor and to Horizon B is greatest (Figure 5). Seamounts of the Magellan Group are scattered within this region and appear to be aligned along the trend inferred for a fracture zone offet. Intra-plate volcanism in the form of volcanoes and elongate ridges that are localized along and within fracture zones is well documented and has been used as an argument for a weakened lithosphere along fracture zones [Vogt, 1974; Batiza, 1981; Lowrie et al., 1986]. The apparent alignment of the southern Magellan Seamounts along this fracture zone in addition to age constraints from dredge samples and cored volcanogenic material indicate that it became one of many focal points for mid-plate volcanism beginning in the Aptian and extending into the Santonian. The observation of the mid-Cretaceous flow/sill unit (Horizon B) possibly onlapping Ita Mai Tai and another unnamed large guyot in the EMB as well as the distinct isotopic signatures of both Himu seamount and the sills recovered at Site 800 indicate that these Aptian age seamounts may have acted as a local source for deep sea volcanism. The recovery of Aptian age pillow basalt at Site 802 , located more than $300 \mathrm{~km}$ from the most proximal seamount, and the huge areal extent of these basalts, indicate that individual seamounts are not the direct volcanic sources in the majority of the EMB and southeast PB.

Large seamounts of the Magellan Group, however, may provide another, more indirect, mechanism for deep sea lava flow emplacement. Lipman et al. [1989] and 
Clague et al. [1990] report the presence of widespread, young lava flows at several sites along the Hawaiian arch approximately $200 \mathrm{~km}$ from the island chain. These remarkably flat-lying areas of up to $25,000 \mathrm{~km}^{2}$, which are characterized by high-acoustic backscatter and hyperbolic reflections on GLORIA and seismic reflection images respectively, correspond to young lava flows. The spatial association of sheet flows with the Hawaiian Flexural Arch, as well as with clusters of Cretaceous seamounts, led Clague et al. [1990] to speculate that lavas are derived from magma concentrated beneath the upbowed lithosphere of the flexural arch and delivered to the surface where the lithosphere locally responds to the seamount load by fracturing.

Individual flows may extend for $100 \mathrm{~km}$, however, the vents for these extensive Hawaiian Arch sheetflows have not been identified, despite the lack of sediment cover [Clague et al., 1990]. Similarly, the morphotectonic expression of such vents, fissures or rifts (spreading or not) is not obvious in the available bathymetric maps or limited seismic profiles in the PB/EMB. In fact, it is difficult to detect tectonic fabric of any kind in the EMB or southeastern PB, most likely due to the masking effects of the pervasive flows and sills. The example of Hawaiian Arch flows also indicates that the seismic expression of potential vents and fissures can be quite subdued. However, the subtle, localized deepening and associated increase in roughness of Horizon B, which we have interpreted as pillow/flow units in the EMB, may represent such fissures and vents (Figure 6). 


\section{Mngnetic Rough-Smooth Boundary}

The distinctive change in the seismic character of Horizon B in the PB from "smooth" to "rough" can also be correlated to a change in magnetic anomaly amplitudes and field strength [Handschumacher et al., 1988]. The "rough-smooth" Horizon B boundary (Figure 3a) is nearly coincident with the magnetic boundary interpretation of Handschumacher et al. [1988] which marks a change in magnetic anomalies from higher field/lower-amplitude anomalies to lower field/higher-amplitude anomalies. A comparable seismic-magnetic boundary within the EMB, which is characterized by the nearly ubiquitous presence of the high-amplitude flat-lying Horizon B, is not apparent. Handschumacher et al. [1988] suggested that the distinct change in magnetic character in the PB may represent a change in spreading rate and/or direction, or a fossil plate boundary. We suggest an additional possibility, that both seismic and magnetic roughsmooth boundaries mark the geographic extent of continuous, mid-Cretaceous, igneous overburden in the PB. If this is the case then the change in magnetic anomaly character at the "Rough/Smooth Boundary" is due to the edge of normally magnetized Cretaceous sills/flows overlying and adjacent to mixed polarity Jurassic oceanic crust.

A similar seismic-magnetic "rough-smooth" boundary associated with the central Venezuelan Basin Fault Zone (CVF) in the Caribbean Sea has also been recognized. The CVF has been interpreted as marking the boundary between an anomalously thick Late Cretaceous igneous province built upon pre-existing oceanic crust and normal thickness 
oceanic crust [Talwani et al. 1977; Diebold et al., 1981]. While the crustal thickness variation across the "Rough/Smooth Boundary" in the PB is not as large, there is also the possibility that this "boundary" may mark the location of a fracture zone (Mendocino?) offsetting the proto-Pacific/Farallon ridge [Handschumacher et al., 1988], which in midCretaceous time acted as a structural boundary to sills and flows originating from sources to the south.

\section{CONCLUSIONS}

1) Analysis of seismic travel time-range data along with drilling results from ODP Leg 129 clearly establish that Horizon B represents the top of high-velocity, massive igneous material throughout the EMB and PB. Horizon $\mathrm{B}$ displays a range of reflection characteristics between two end-member modes. It corresponds to the top of Jurassic oceanic crust where it has a high relief, undulating, lower amplitude and diffractive character. It corresponds to mid-Cretaceous sills/flows overlying oceanic crust where it appears flat-lying, high-amplitude, discontinuous and often "smooth". These Horizon B reflection characteristics calibrated by Leg 129 drill sites indicate that a semi-continuous sequence of mid-Cretaceous deep sea flows/sills overlies Jurassic sediments and oceanic crust throughout an area of approximately $500,000 \mathrm{~km}^{2}$ in the EMB and southeast PB.

2) Sonobuoy refraction data indicate no significant $(>1 \mathrm{~km})$ difference in crustal thicknesses between areas overlain by documented mid-Cretaceous sills/flows and areas 
with Jurassic oceanic crust free of such younger igneous overburden. Based on subHorizon B reflections and velocity information from sonobuoys, we estimate the thickness of the mid-Cretaceous sill/flow/sediment complex at $100-400 \mathrm{~m}$. The volume of deep sea sills and flows in the EMB/PB is estimated at $0.25 \times 10^{6} \mathrm{~km}^{3}$, approximately 200 times less than the volume estimated for the Ontong-Java Plateau.

3) A distinct smooth-to-rough Horizon B boundary is found in the southeast PB where the continuous overburden of mid-Cretaceous flows/sills pinch out and expose Jurassic oceanic crust. Northwest of this boundary, occurrences of late Barremian - early Aptian sills/flows are documented, but are believed to be localized and associated with individual seamounts of similar age and isotopic character.

4) The change in magnetic anomaly character in the so called Jurassic Magnetic Quiet Zone of the PB from rough to smooth is associated with the change in reflection character of Horizon B from smooth to rough. This kind of magnetic and seismic boundary is not observed in the EMB, and it is believed both boundaries mark the edge of pervasive deep sea sill and flow overburden. It is suggested that this "boundary" was created by a fracture zone offset of the proto-Pacific/Farallon plate boundary.

5) The Ogasawara Fracture Zone acted as a focal point for Aptian age and younger extrusive activity as indicated by the alignment and age of seamounts. There appears to be morphotectonic and geophysical evidence for both fracture zone and flexural effects within the broad region separating the PB and EMB. This feature has separated the two basins 
since at least $160 \mathrm{Ma}$.

6) Intrabasin morphotectonic structures other than seamounts, which could suggest a local $(<100 \mathrm{~km})$ source location for the extensive cover of deep sea sills and flows, are not evident on seismic or bathymetric records. However, the continuity of the sill/flow surface up the Caroline Ridge, the orientation of the "rough/smooth" Horizon B boundary, age and geochemical similarities between MORBs recovered in the Nauru Basin, EMB and the Ontong-Java Plateau suggest that the volcanism in these areas are closely related. We speculate that the deep sea sills/flows of varying thicknesses found in the EMB, southeast PB were locally emplaced through seamounts such as Ita Mai Tai with associated arch volcanism, and regionally along fissures/failed rifts which are manifested as subtle changes in depth and reflection character of volcanic basement.

\section{ACKNOWLEDGEMENT}

This work was part of a joint U.S. - French effort to investigate the western Pacific basins. We wish to thank the ships crew and scientific party of the R/V Fred Moore (RIP) cruise FM35-12 and N/O Le Suroit. Perry Crampton and fellow airgun techs worked beyond the call of duty. Steffen Saustrup, Mark Wiederspahn, Patty Ganey at UTIG and Marc Schaming, Jacques Renault, Cecille Pourcellot and Roland Schlich at IPG, Strasbourg provided invaluable assistance in the processing of FM35-12 and MESOPAC II seismic data. John Mutter kindly donated the use of the L-DGO processing facilities 
during sonobuoy analysis. John Diebold contributed interactive software (JDSEIS), and along with Emilio Vera, provided helpful advice and discussion concerning sonobuoy data analysis/interpretation. Discussions with Nancy Grindlay, and Malcolm Pringle and reviews from Beth Ambos, Tom Brocher and Will Sager improved this paper. This project was funded by NSF grants OCE 86-13867 (R.Larson), OCE 86-13641 (T. Shipley) and from JOI/USSAC Ocean Drilling Fellowship (JSG-CY5-4) and a USSAC grant (20431) to the first author. 


\section{TABLES AND FIGURES}


Table 1. Velocity - Depth functions below seafloor given in terms of a combination of constant velocity gradient layers with top and bottom velocities for each layer given in column 3. Dashes indicate constant velocity layer. The thickness of each layer given in seconds (sec) and kilometers (km) (column 4). Velocity gradient ( $\left(\mathrm{sec}^{-1}\right)$ for each layer is given in column 5 .

Table 2. Layer 2 thicknesses as defined by velocity and velocity gradient, and total crustal thicknesses are given. Mantle arrivals were not observed for sonobuoy 7 (SB7). 


\begin{tabular}{|c|c|c|c|c|c|c|}
\hline \multirow{2}{*}{$\frac{S B H}{4 m}$} & \multirow{2}{*}{$\begin{array}{l}\text { Layer } \\
1 \\
2 \\
3 \\
4\end{array}$} & \multirow{2}{*}{$\begin{array}{l}\text { Wacer } \\
\text { Depeh (m) }\end{array}$} & \multirow{2}{*}{$\begin{array}{l}V_{p} \\
(\mathrm{~cm} / \mathrm{s}) \\
2.0 . \\
4.41-6.47 \\
6.47-6.76 \\
6.76 .\end{array}$} & \multicolumn{2}{|c|}{$\begin{array}{l}\text { Thickness } \\
(\mathrm{sec})-(\mathrm{cm})\end{array}$} & \multirow{2}{*}{$\begin{array}{l}\text { Gradient } \\
(\sec -1) \\
0.0 \\
1.61 \\
0.23 \\
0.0\end{array}$} \\
\hline & & & & $\begin{array}{r}.42 \\
.47 \\
.38 \\
1.36\end{array}$ & $\begin{array}{l}.42 \\
1.28 \\
1.24 \\
4.59\end{array}$ & \\
\hline $6 m$ & $\begin{array}{l}1 \\
2 \\
3 \\
4\end{array}$ & 5660 & $\begin{array}{l}2.0 \\
4.15-6.38 \\
6.38-7.03 \\
7.03\end{array}$ & $\begin{array}{l}.40 \\
.64 \\
.46 \\
1.10\end{array}$ & $\begin{array}{l}.40 \\
1.69 \\
1.54 \\
3.89\end{array}$ & $\begin{array}{l}0.0 \\
1.32 \\
0.42 \\
0.0\end{array}$ \\
\hline 22 & $\begin{array}{l}1 \\
2 \\
3 \\
4\end{array}$ & 5680 & $\begin{array}{l}20 . \\
3.98-6.67 \\
6.67-6.92 \\
6.92 .\end{array}$ & $\begin{array}{l}.41 \\
.59 \\
.70 \\
.96\end{array}$ & $\begin{array}{r}.41 \\
1.58 \\
2.38 \\
3.33\end{array}$ & $\begin{array}{l}0.0 \\
1.71 \\
0.11 \\
0.0\end{array}$ \\
\hline $\operatorname{lm}$ & $\begin{array}{l}1 \\
2 \\
3 \\
4\end{array}$ & 5585 & $\begin{array}{l}2.0 \\
4.13-6.75 \\
6.75-7.17 \\
7.17\end{array}$ & $\begin{array}{r}.50 \\
.61 \\
.43 \\
1.06\end{array}$ & $\begin{array}{l}.50 \\
1.65 \\
1.48 \\
3.82\end{array}$ & $\begin{array}{l}0.0 \\
1.58 \\
0.28 \\
0.0\end{array}$ \\
\hline $2 m$ & $\begin{array}{l}1 \\
2 \\
3 \\
4\end{array}$ & 5680 & $\begin{array}{l}2.0- \\
4.63-6.87 \\
6.87-6.98 \\
6.98\end{array}$ & $\begin{array}{l}.46 \\
.49 \\
22 \\
1.44\end{array}$ & $\begin{array}{l}.46 \\
1.41 \\
0.75 \\
5.03\end{array}$ & $\begin{array}{l}0.0 \\
1.59 \\
0.15 \\
0.0\end{array}$ \\
\hline $3 a$ & $\begin{array}{l}1 \\
2 \\
3 \\
4\end{array}$ & 5755 & $\begin{array}{l}20 . \\
432.621 \\
6.21-6.26 \\
6.6\end{array}$ & $\begin{array}{r}35 \\
.47 \\
.12 \\
1.62\end{array}$ & $\begin{array}{l}35 \\
1.23 \\
0.73 \\
5.36\end{array}$ & $\begin{array}{l}0.0 \\
1.54 \\
0.07 \\
0.0\end{array}$ \\
\hline 23 & $\begin{array}{l}1 \\
2 \\
3 \\
4\end{array}$ & 5660 & $\begin{array}{l}2.0 \\
4.45-6.43 \\
6.43-7.09 \\
7.09\end{array}$ & $\begin{array}{r}.43 \\
.69 \\
.35 \\
1.08\end{array}$ & $\begin{array}{l}.43 \\
1.87 \\
1.17 \\
3.83\end{array}$ & $\begin{array}{l}0.0 \\
1.06 \\
0.57 \\
0.0\end{array}$ \\
\hline $\sin$ & $\begin{array}{l}1 \\
2 \\
3 \\
4 \\
5 \\
\end{array}$ & 5745 & $\begin{array}{l}20- \\
3.70-6.03 \\
6.03-6.24 \\
6.24-6.98 \\
6.98\end{array}$ & $\begin{array}{r}.34 \\
.63 \\
.09 \\
.53 \\
1.16 \\
\end{array}$ & $\begin{array}{l}34 \\
1.52 \\
0.29 \\
1.74 \\
4.27 \\
\end{array}$ & $\begin{array}{l}0.0 \\
1.53 \\
0.73 \\
0.42 \\
0.0 \\
\end{array}$ \\
\hline 21 & $\begin{array}{l}1 \\
2 \\
3 \\
4\end{array}$ & . 5685 & $\begin{array}{l}2.0- \\
3.92-6.06 \\
6.05-6.96 \\
6.96 .\end{array}$ & $\begin{array}{l}26 \\
.59 \\
.62 \\
.95\end{array}$ & $\begin{array}{l}.26 \\
1.46 \\
201 \\
3.25\end{array}$ & $\begin{array}{l}0.0 \\
1.46 \\
0.45 \\
0.0\end{array}$ \\
\hline 20 & $\begin{array}{l}1 \\
2 \\
3 \\
4 \\
5 \\
\end{array}$ & 6100 & $\begin{array}{l}1.8-1.8 \\
20-20 \\
24-2.4 \\
4.60-7.00 \\
7.00\end{array}$ & $\begin{array}{r}.30 \\
.52 \\
.30 \\
1.23 \\
.80 \\
\end{array}$ & $\begin{array}{l}.27 \\
0.52 \\
0.36 \\
3.50 \\
2.80 \\
\end{array}$ & $\begin{array}{l}0.0 \\
0.0 \\
0.0 \\
0.68 \\
0.0 \\
\end{array}$ \\
\hline 7 & $\begin{array}{l}1 \\
2 \\
3 \\
4\end{array}$ & 5925 & $\begin{array}{l}1.9 \cdot \\
3.81-5.83 \\
5.83-6.63 \\
6.77 \cdot\end{array}$ & $\begin{array}{l}32 \\
.70 \\
.42 \\
.70\end{array}$ & $\begin{array}{r}30 \\
1.69 \\
1.31 \\
237\end{array}$ & $\begin{array}{l}0.0 \\
1.2 \\
0.61 \\
0.0\end{array}$ \\
\hline 8 & $\begin{array}{l}1 \\
2 \\
3 \\
4 \\
5\end{array}$ & 5940 & $\begin{array}{l}1.9- \\
3.66-5.94 \\
5.94-6.33 \\
6.33-6.98 \\
6.73 .\end{array}$ & $\begin{array}{l}33 \\
.72 \\
.16 \\
.28 \\
1.25\end{array}$ & $\begin{array}{l}32 \\
1.73 \\
0.49 \\
0.93 \\
4.19\end{array}$ & $\begin{array}{l}0.0 \\
1.32 \\
0.8 \\
0.7 \\
0.0\end{array}$ \\
\hline 18 & $\begin{array}{l}1 \\
2 \\
3 \\
4\end{array}$ & 5930 & $\begin{array}{l}1.78- \\
3.90-6.04 \\
6.04-6.45 \\
6.98\end{array}$ & $\begin{array}{l}30 \\
.82 \\
3 \\
1.39\end{array}$ & $\begin{array}{l}27 \\
2.04 \\
0.92 \\
4.86\end{array}$ & $\begin{array}{l}0.0 \\
1.05 \\
0.44 \\
0.0\end{array}$ \\
\hline
\end{tabular}

\begin{tabular}{|c|c|c|c|}
\hline \multicolumn{4}{|c|}{ Table 2} \\
\hline SB: & $\begin{array}{l}\text { Lyer } 27 \\
(6.4 \mathrm{~km}\end{array}$ & $\begin{array}{l}\operatorname{css}(\mathrm{km}) \\
-2+1)\end{array}$ & $\begin{array}{l}\text { Toul Crusal } \\
\text { Thicloness (km) }\end{array}$ \\
\hline $4 m$ & 1.3 & 1.3 & 7.12 \\
\hline $6 m$ & 1.7 & 1.7 & 7.12 \\
\hline 22 & 1.42 & 1.58 & 7.28 \\
\hline $\ln$ & 1.44 & 1.65 & 6.95 \\
\hline $2 m$ & 1.11 & $1.4 !$ & 7.18 \\
\hline $3 m$ & 1.96 & 1.23 & 7.31 \\
\hline 23 & 1.84 & 1.87 & 6.86 \\
\hline $8 \mathrm{~m}$ & 1.90 & 1.52 & 7.83 \\
\hline 21 & 222 & 1.46 & 6.76 \\
\hline 20 & 2.61 & - & 6.35 \\
\hline 7 & 26 & 1.7 & - \\
\hline 8 & 2.32 & 1.73 & 7.34 \\
\hline 18 & 285 & 204 & 7.82 \\
\hline
\end{tabular}


Figure 1. Magnetic Lineations of the western Pacific compiled by R.L. Larson from Hilde et al. [1976], Larson [1976], Nakanishi et al. [1989], Mammerickx and Sharman [1988], Tamaki and Larson [1988], Handschumacher et al. [1988], and Sager et al. [1988]. Magnetic isochron M17 is highlighted and approximates the Cretaceous Jurassic boundary. Dots locate selected DSDP Sites 199, 585, 462 and all of ODP Leg 129 Sites 800, 801 and 802. Boxed region is shown in Figures 2 and 3. 


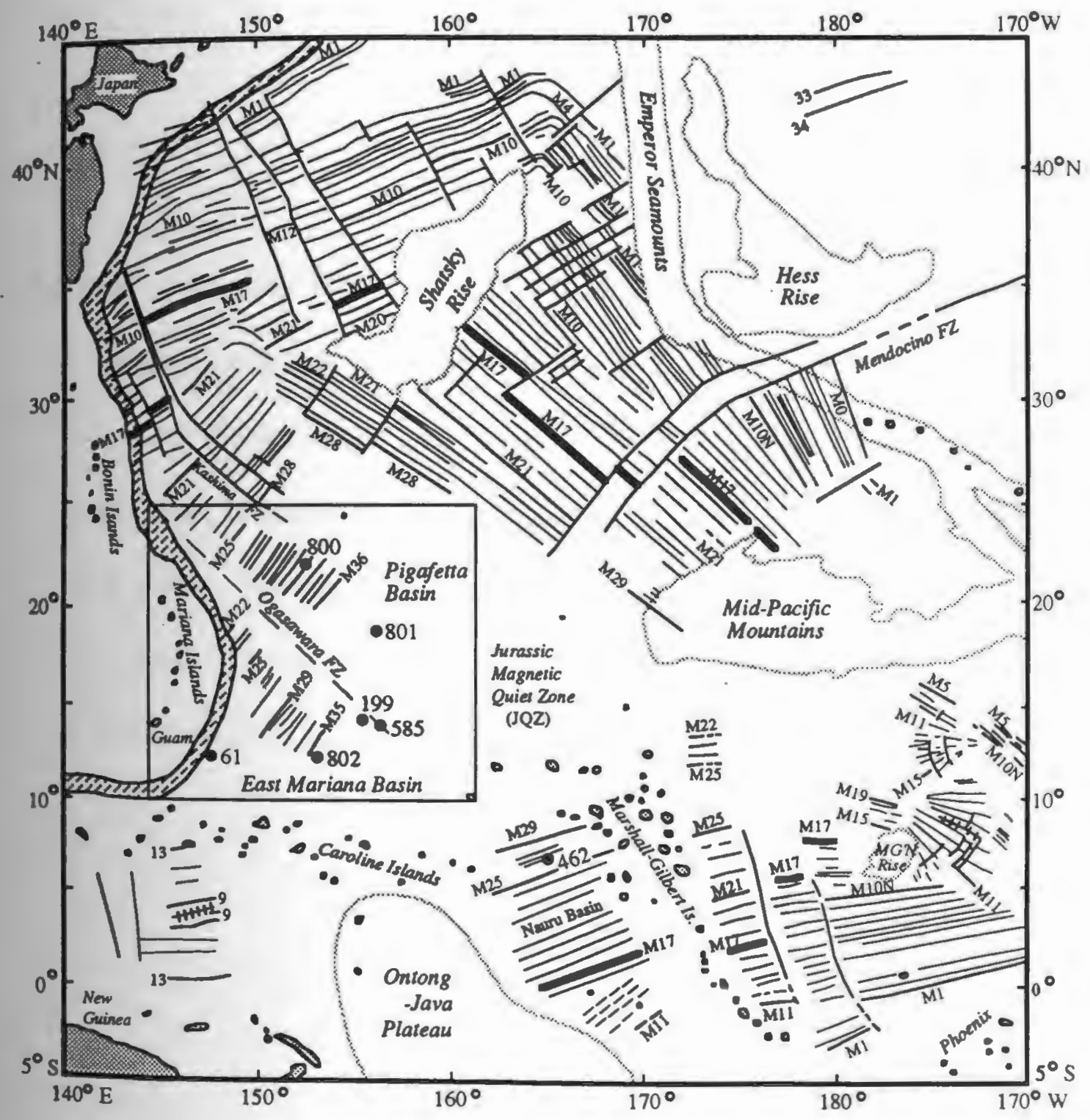


Figure 2. Bathymetry of the central western Pacific modified from Brenner and Angell [in press] with location of selected DSDP sites and all of ODP Leg 129 sites. The $5500 \mathrm{~m}$ contour is highlighted and the $3000 \mathrm{~m}$ contour is shown as a lighter line. Magnetic anomalies modified from Tamaki et al. [1987] and Handschumacher et al. [1988]. The bold solid line indicates coverage of the MESOPAC II and FM3512 seismic surveys. The broad area inferred for the location of the Ogasawara Fracture Zone is bounded by the dashed line. 


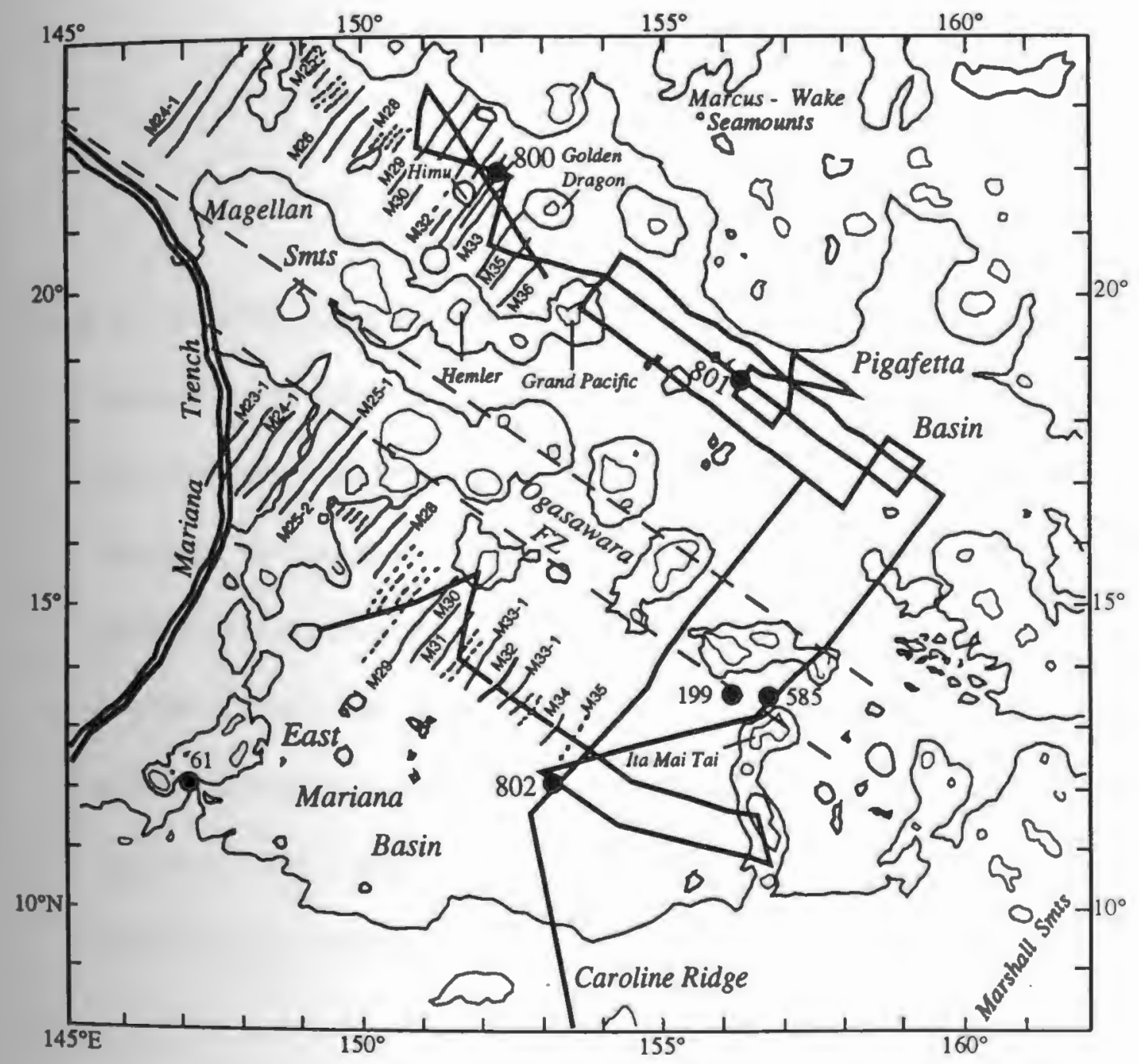


Figure 3a. Solid line indicates coverage of the FM35-12 and MESOPAC II regional seismic surveys with location of sonobuoy stations and transects in subsequent figures (heavy solid lines marked SB\# and F\# respectively). The endpoints of composite profiles shown in Figure 5 are marked A-A', B-B' and C-C' and highlighted as shown in the legend. The boxed region is enlarged and shown in two inset figures. The spatial relationship of rough/smooth Horizon B and the magnetic boundary as identified by Handschumacher et al. [1988] is shown in the top inset and the bottom inset more clearly displays track geometry and figure/sonobuoy locations. Dots show DSDP/ODP site locations. 

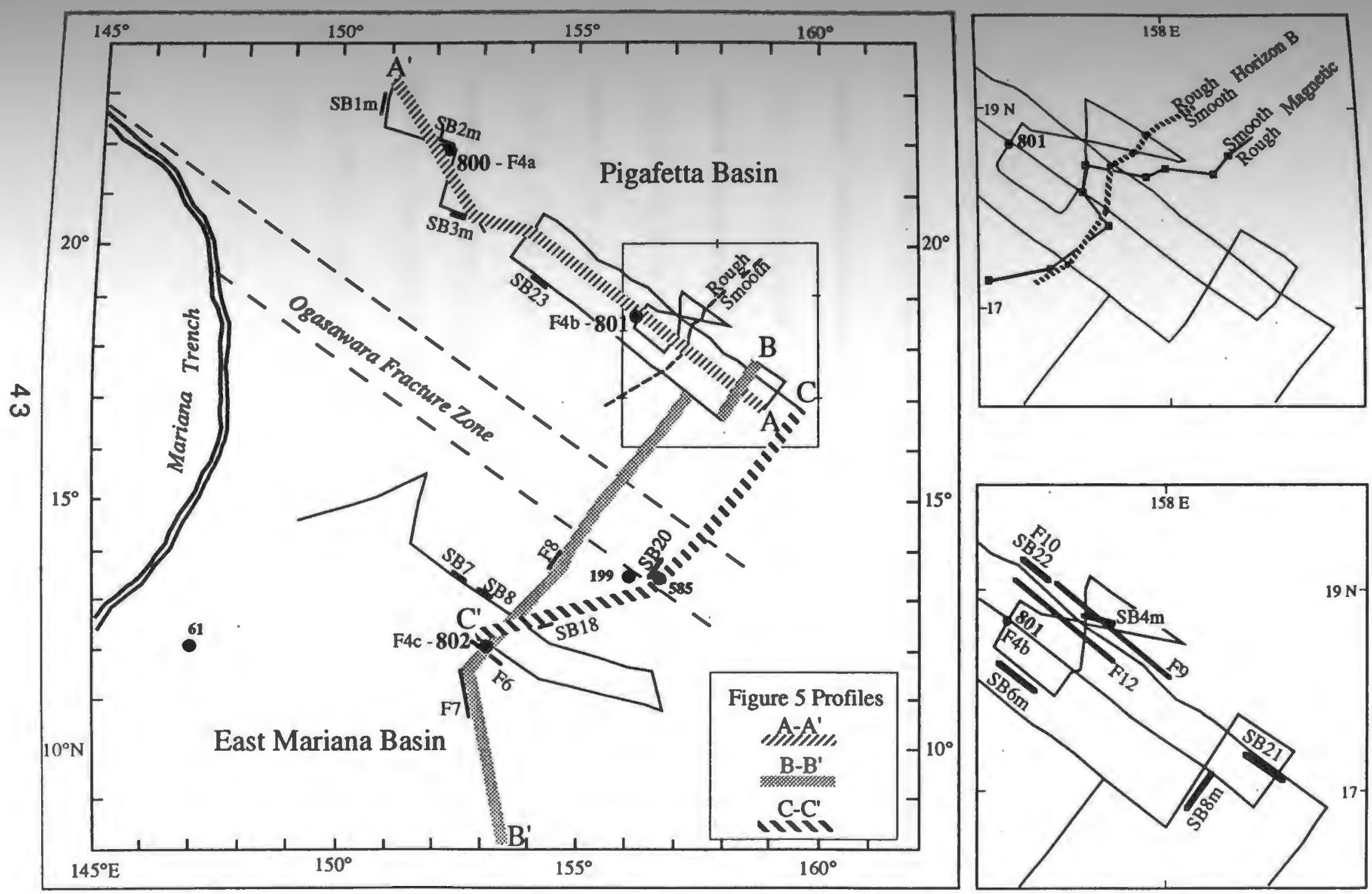
Figure $3 \mathrm{~b}$. Simplified bathymetry (5500 m contour is shown) of the central western Pacific modified from Brenner and Angell, [in press]. The reflection character of Horizon B and its interpretation are indicated along track from Abrams et al. [in press]. The oceanic crust in the entire EMB and southeast PB $\left(\sim 500,000 \mathrm{~km}^{2}\right)$ is overlain by mid-Cretaceous sills/flows (Aptian age or younger). Only a few restricted areas in the PB are confidently interpreted to contain Jurassic-age oceanic crust with no massive igneous overburden. Horizon B in extended areas (primarily in the PB) is more tentatively interpreted as Jurassic age oceanic crust with midCretaceous sill/flow overburden possible. Radiometric ages of basalt are given in Ma for Leg 129 Sites from Pringle [in press], and for seamounts from Ozima et al. [1983], Pringle, [pers. comm. 1991], Pringle [1992], and Winterer et al., [this volume]. 


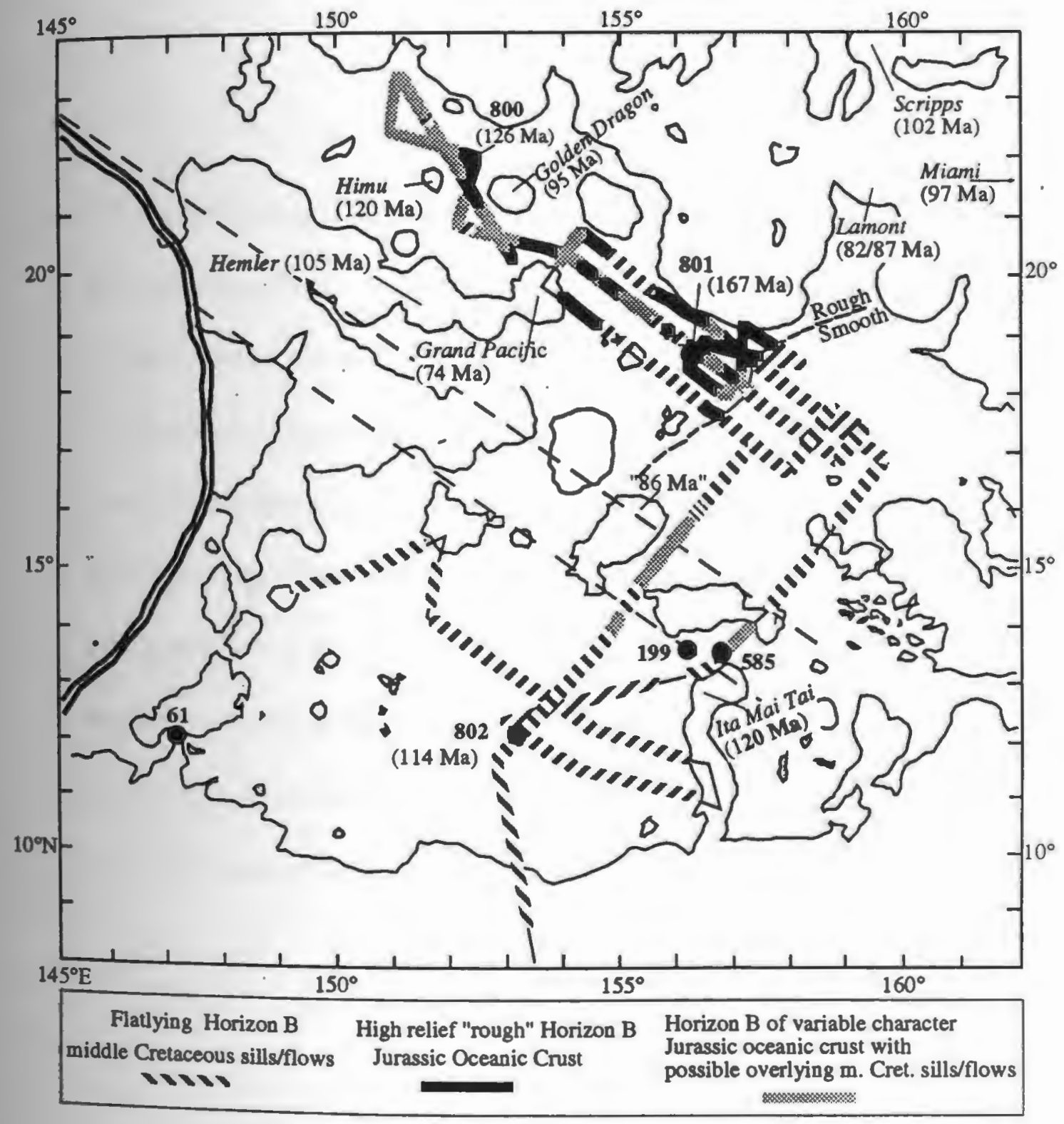


Figure 4a-b-c. Summary of seismic stratigraphy at ODP Leg 129 Sites 800, 801, 802 showing generalized correlations with lithologic units, ages and depths, with emphasis on key reflective horizons such as igneous basement and shallowest chert ("first" chert) [Lancelot and Larson et al.,1990, Pringle, in press]. Site 800 imaged with SCS waterguns (two 80 in3) obtained on approach to Site 800 during Leg 129; seismic profiles for closest point of approach (CPA) to Sites 801 and 802 during MESOPAC II. These single channel watergun records were processed and displayed with the following parameters: water-velocity F/K migration, mute, 2trace mix, band-pass filter $25-100 \mathrm{~Hz}, 500 \mathrm{msec} A G C$, and vertical exaggeration $\sim 22 \mathrm{X}$ at $1.5 \mathrm{~km} / \mathrm{s} . \mathrm{O} / \mathrm{C}=$ on course, UTC $=$ Universal Time Code. 

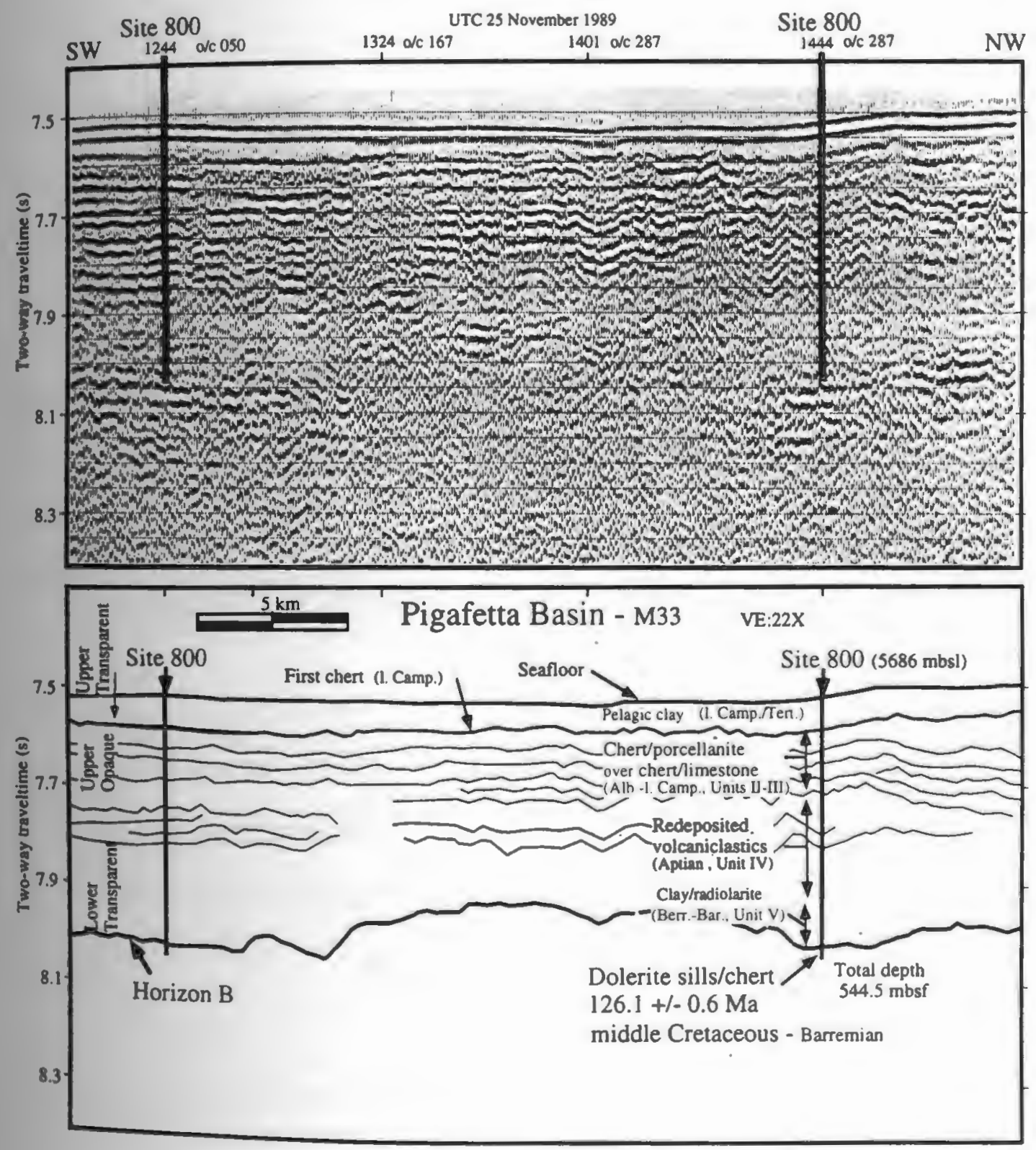

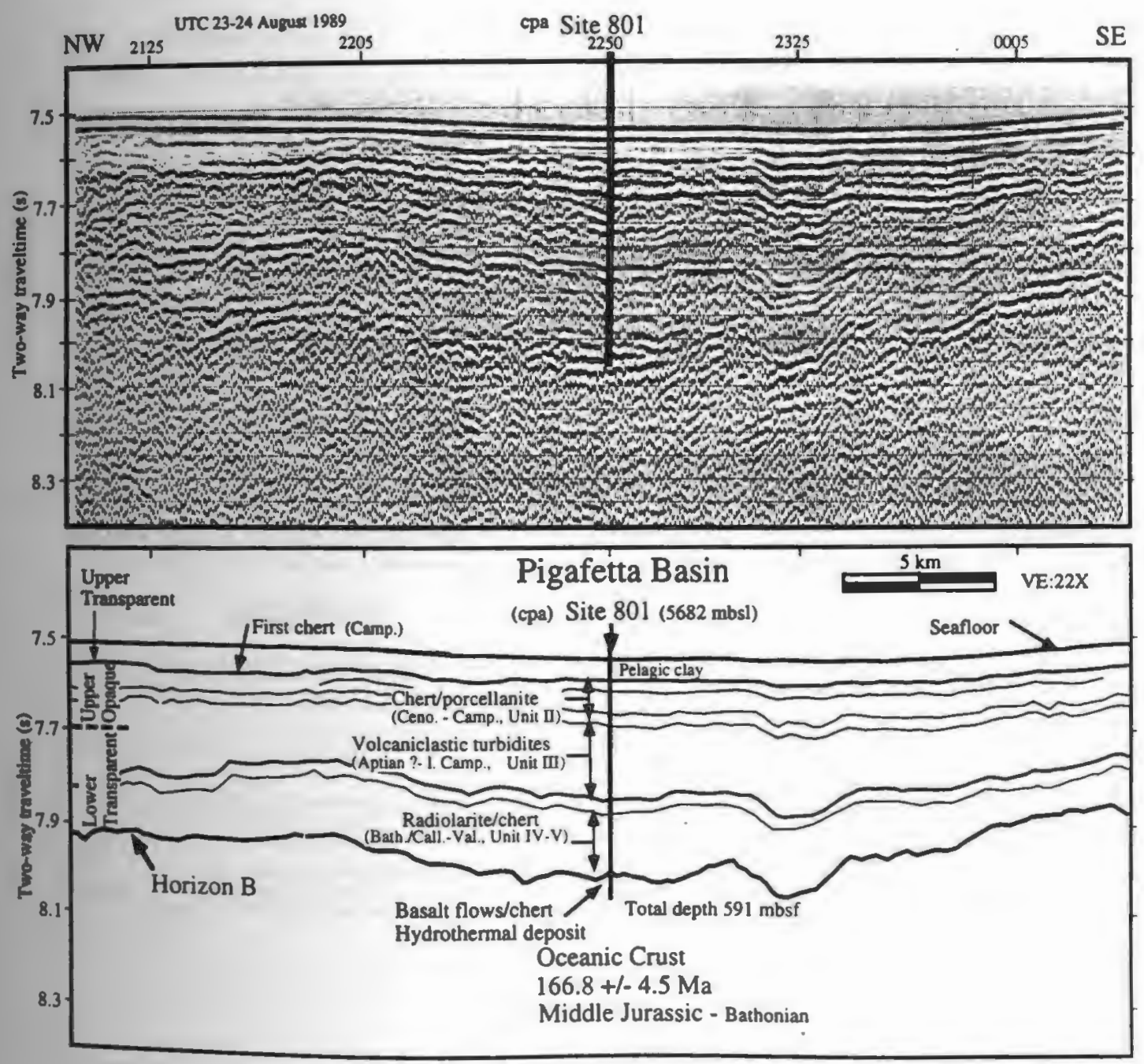

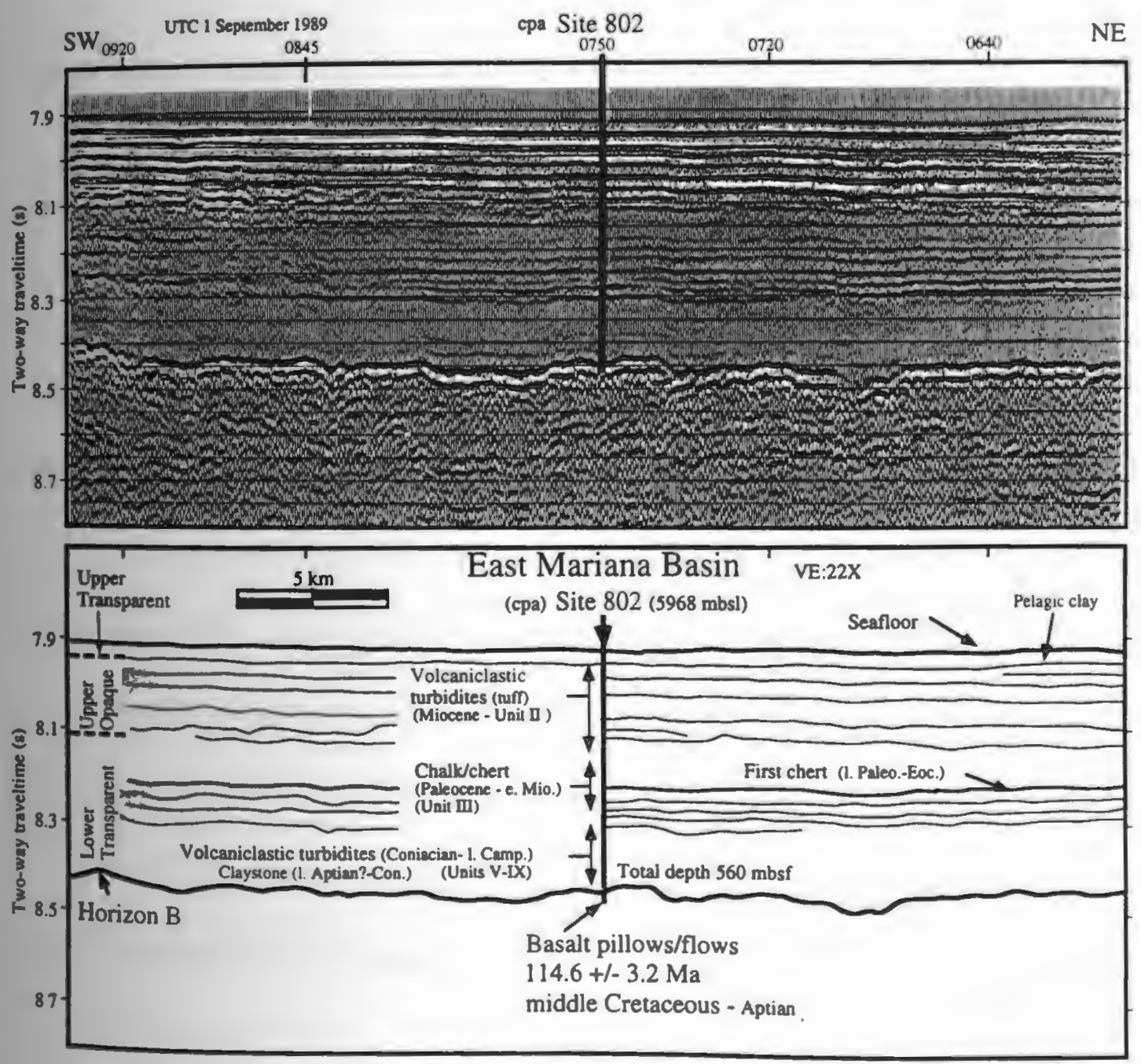
Figure 5a,b,c. Three $900-1300-\mathrm{km}$ long profiles showing selected reflections digitized from MCS airgun and near-channel watergun data (see Figure 3a track chart for locations A-A', B-B' and C-C'). The deepest horizon (heavy line) represents the top of high velocity igneous material. This horizon is characterized and interpreted from direct sampling at three widely separated ODP sites, reflection character and from velocity structure. The middle horizon represents the top of the shallowest chert - porcellanite - silicified limestone (First chert). The top horizon represents the seafloor. Note the depth difference between the PB and EMB, the deepening of Horizon B associated with the Ogasawara Fracture Zone and flexural moat of the Magellan Seamounts and the uniformly flat Horizon B surface (even at VE=133X) in the EMB and southeast PB compared to the high relief basement of the PB northwest of the rough-smooth boundary. Radiometric ages are from Pringle [in press]. 


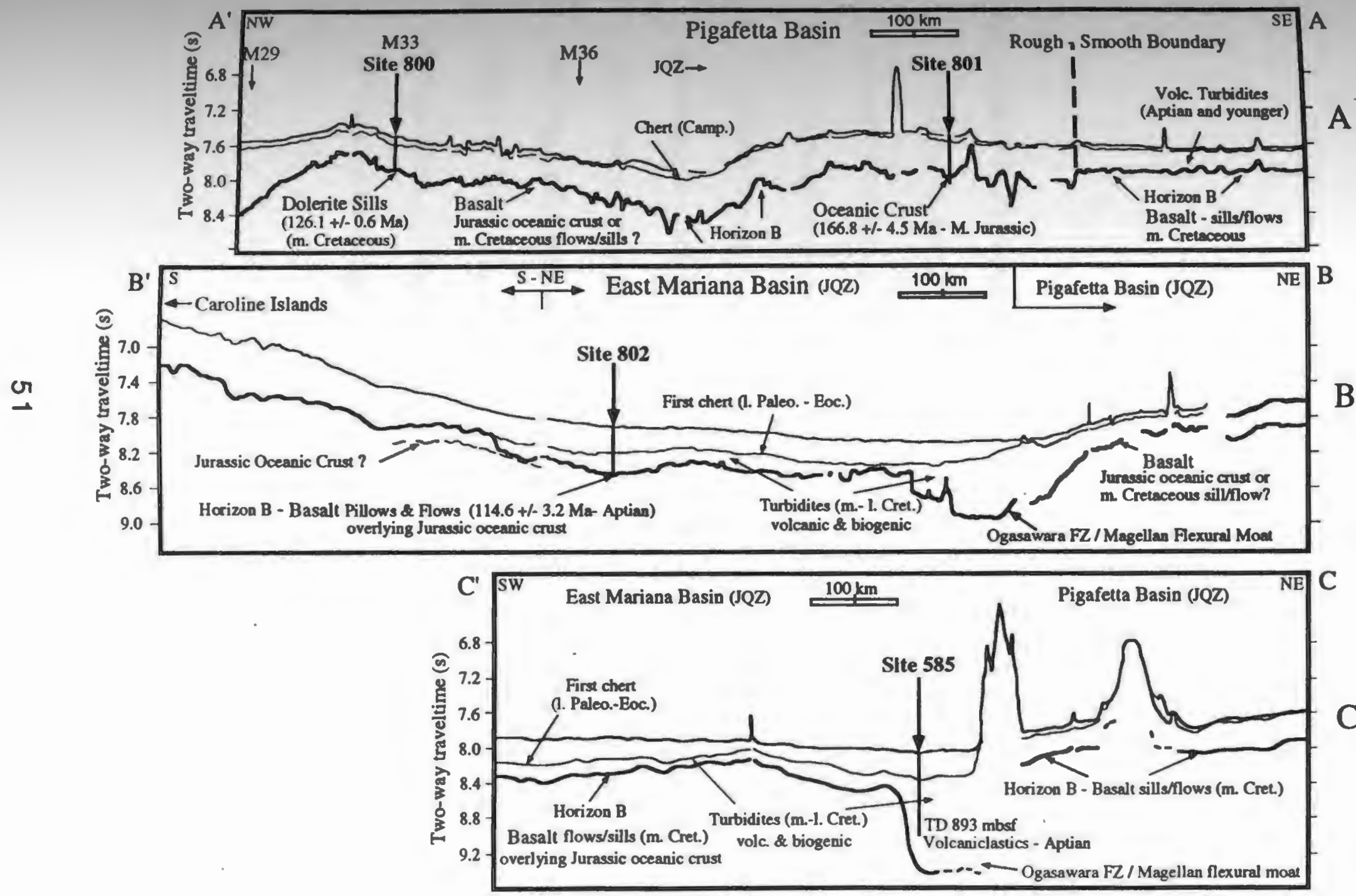


Figure 6. FM35-12 MCS airgun profile at its closest point of approach (cpa) to Site 802 (approximately $4 \mathrm{~km}$ to the east). The depth and character of the basement reflector changes from a flat-lying, "smooth" event at 8.3 stwt to a "rougher" reflection at 8.4 stwt (marked by vertical lines). The "rough" (diffractive) Horizon B reflection correlates to the top of extrusive basalt (pillow units) and the shallow, "smooth" (non-diffractive) Horizon B reflection is interpreted as igneous intrusives or sheet flows. The relatively rough surface, however, remains flat-lying and shows much less overall relief than does the Horizon B in the PB northwest of the rough-smooth boundary. The processing and display parameters are as follows: pre-stack spike deconvolution, 120-fold stack, band-pass 20-60 filter $\mathrm{Hz}$, F/K migration, 500 msec AGC and vertical exaggeration of $\sim 22 \mathrm{X}$ at $1.5 \mathrm{~km} / \mathrm{s}$. 


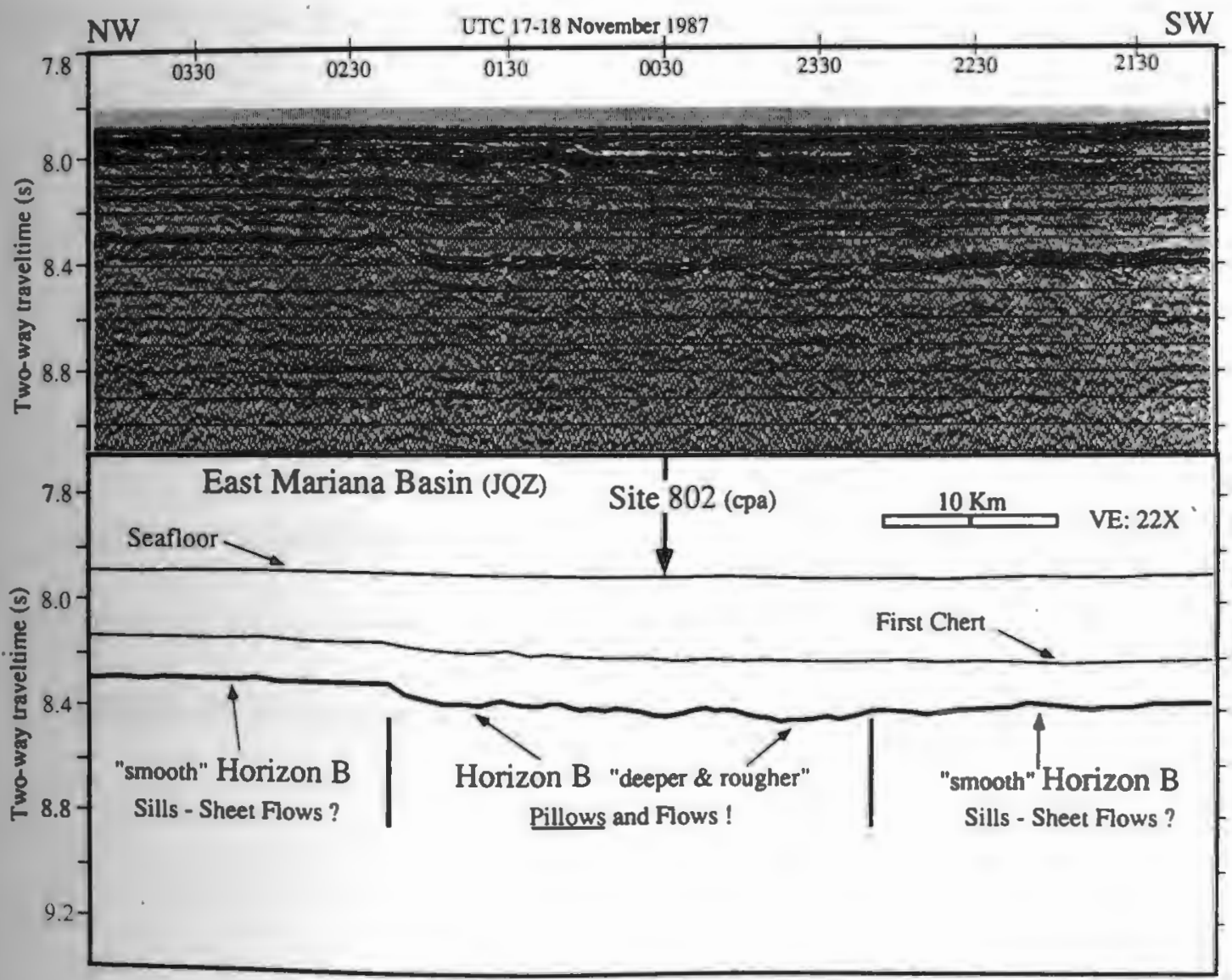


Figure 7. MESOPAC II SCS watergun profile in the southern EMB (location Figure 3a). Site 802 penetrated extrusive basalt dated at $114+/-3.2$ m.y. beneath Aptian age sediment, this horizon (Horizon B) appears faulted and is onlapped by late Paleocene chert/chalks and underlying Late Cretaceous turbidites. The basalt surface penetrated at Site 802 continues up onto the Caroline Ridge. A weak semicontinuous, relatively high relief horizon imaged beneath the rising flow/sill surface is interpreted as the top of oceanic crust. A similar reflection geometry is observed on both airgun and watergun records in other restricted portions of the EMB. This MESOPAC II watergun record is processed and displayed as indicated in Figure 4. 


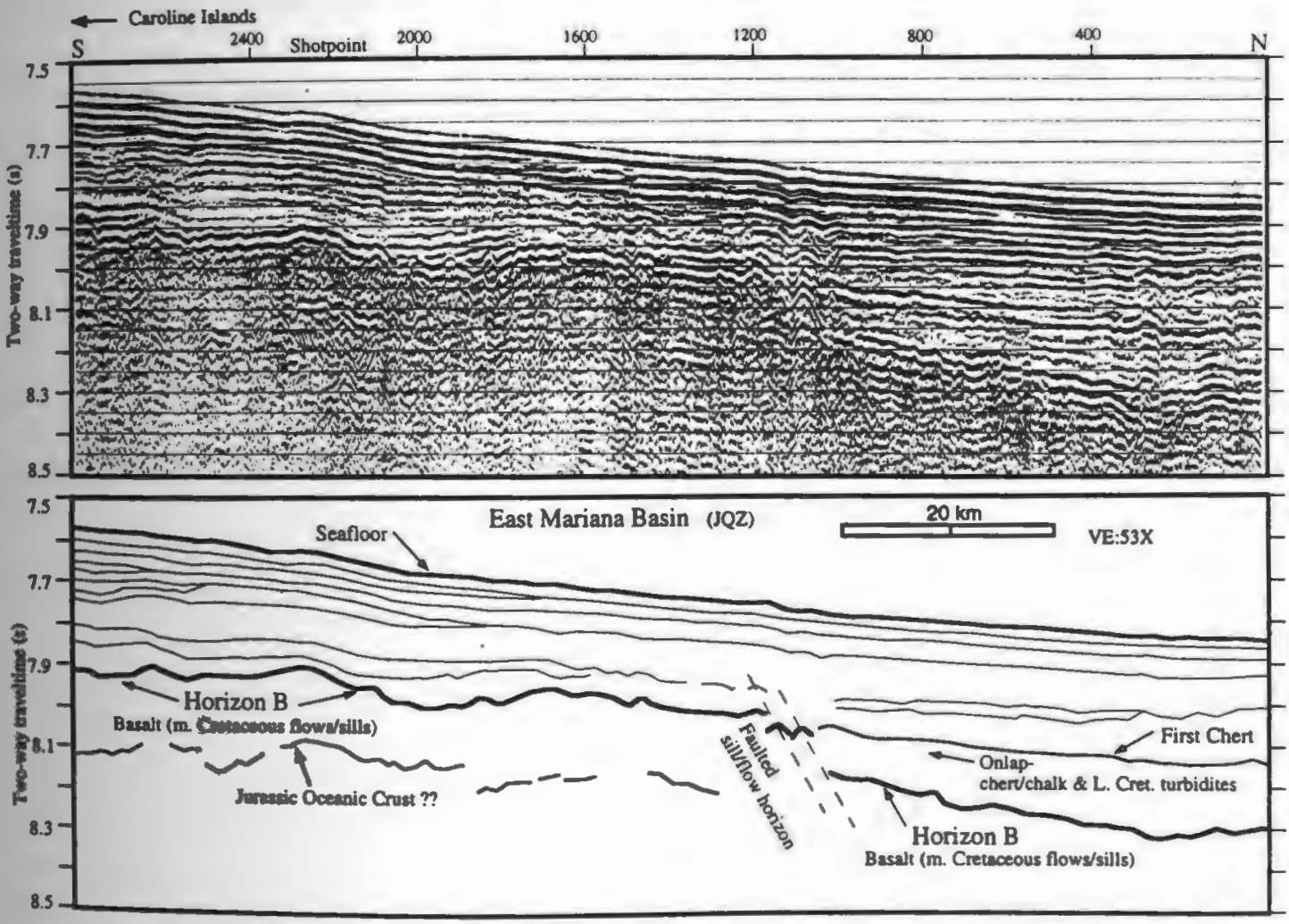


Figure 8. MESOPAC II line 18 near-channel watergun profile in the EMB (location Figure 3a) showing Horizon B where it appears flat-lying, "smooth" and laterally discontinuous "slablike". This type of reflection geometry is not characteristic of the top of oceanic crust and is interpreted as sills emplaced at different stratigraphic levels overlying an unimaged oceanic crust. This seismic record is processed and displayed as indicated in Figure 4. 

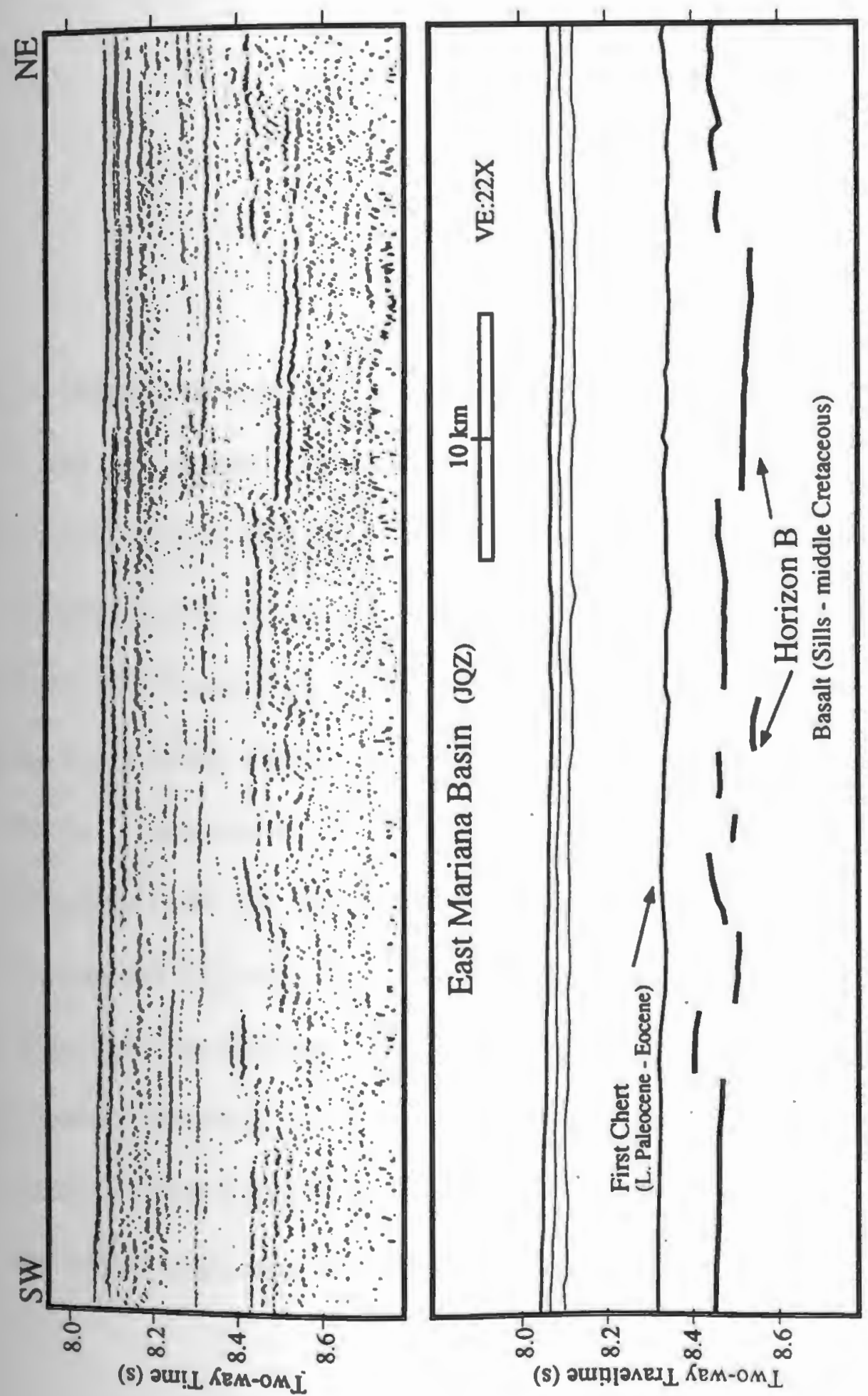
Figure 9. FM35-12 MCS airgun profile in the JQZ of the PB along an inferred flowline course and displayed at true relative amplitude. The continuous, flat-lying (at VE:75x) and high-amplitude Horizon B reflection southeast of the rough-smooth boundary deepens and appears to be contiguous with an undulating, diffractive and lower reflection amplitude "rough" Horizon B. The "rough" Horizon B correlates to the top of middle Jurassic age oceanic crust (e.g. Site 801) and the "smooth" horizon is interpreted as mid-Cretaceous sills and flows overlying the unimaged top of oceanic crust. The rough/smooth boundary appears on all five of our tracks crossing this area and a comparable boundary is not apparent in the EMB. We suggest that the boundary marks the limit of semi-continuous mid-Cretaceous (Aptian?) flows/sills. The processing and display parameters are the same as in Figure 6 except displayed with true relative amplitude, band-pass filter $8-25 \mathrm{~Hz}$ and vertical exaggeration of $\sim 75 \mathrm{X}$ at $1.5 \mathrm{~km} / \mathrm{s}$. 

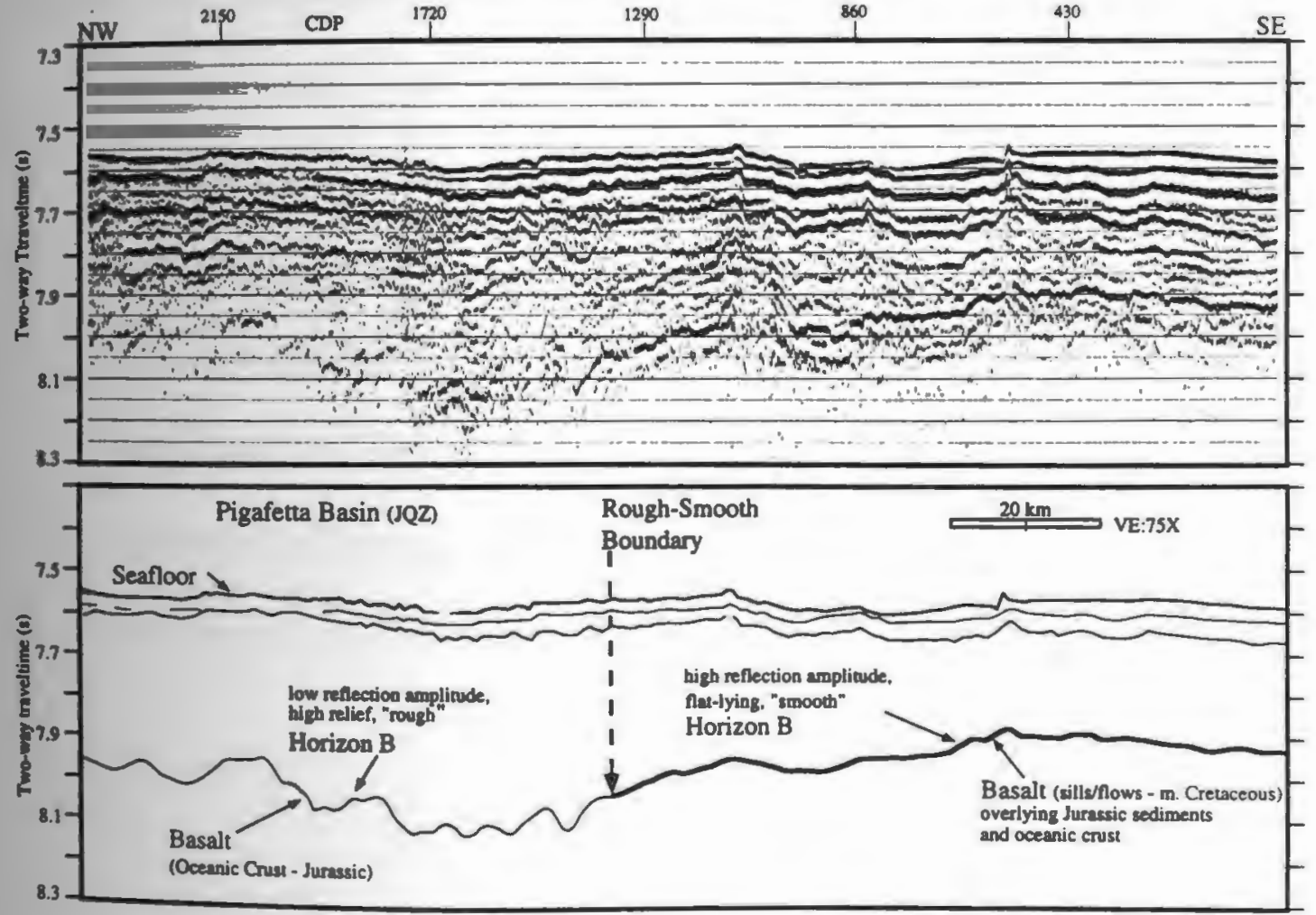
Figure 10a,b. Traveltime - range data from sonobuoy 22 in the JQZ of the PB located 55 $\mathrm{km}$ Northwest of ODP Site 801 is shown at reduced travel time $(7 \mathrm{~km} / \mathrm{s}), 500 \mathrm{msec}$ AGC, band-pass filter 8-25 Hz. Refracted/reflected arrivals of note are labeled. Refracted second arrivals (labeled "shallow crustal arrivals") that are tangent to Horizon B (labeled "top of oceanic crust") are clearly visible between $5-8 \mathrm{~km}$ and continuous with refracted first arrivals observed beyond $30 \mathrm{~km}$ range. Shallower high-velocity first arrivals are not observed in contrast to those revealed in sonobuoys 8 and 18 in the EMB (Figure 13). 


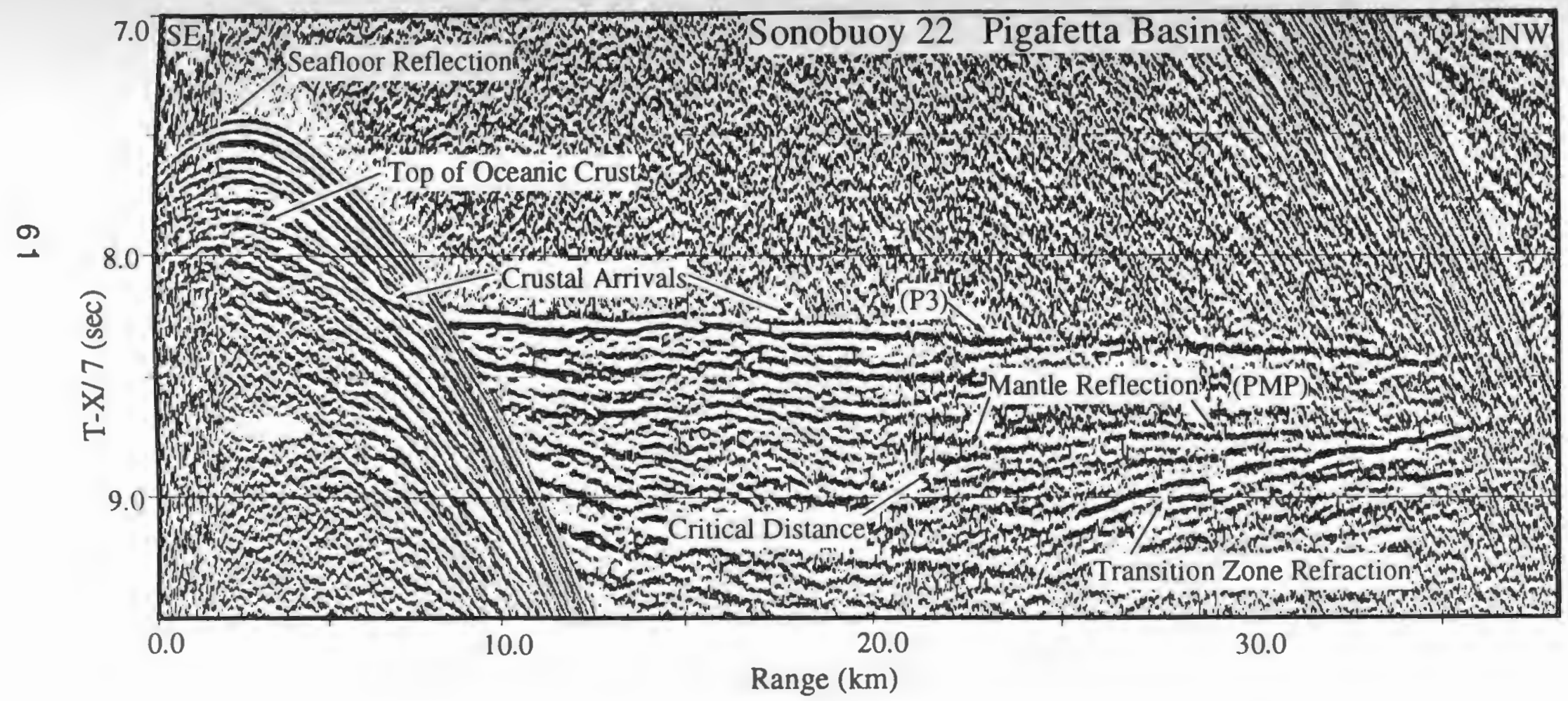




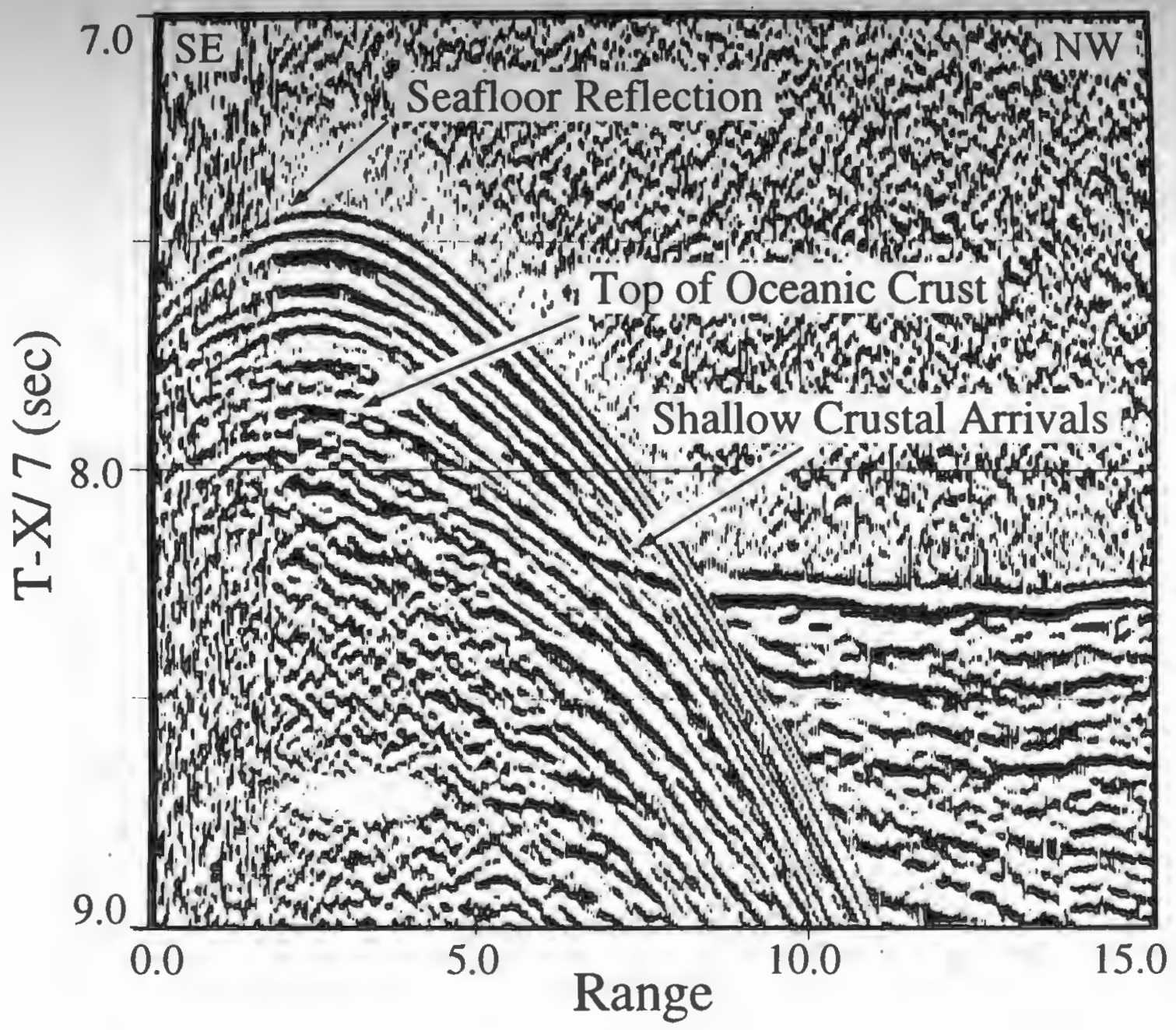


Figure 11. A) Velocity verses two-way travel time in seconds below seafloor (sbsf) from sonobuoy data collected during FM35-12 and MESOPAC II in the EMB and PB. Crustal velocities begin from 0.3 to 0.6 sbsf (approximately 300 to $600 \mathrm{mbsf}$ ), with the exception of sonobuoy 20. Sonobuoy 20 (dashed line) was shot over DSDP 585 and indicates that approximately $1150 \mathrm{~m}$ of sediment overlie the relatively deep basement imaged at the far eastern edge of the EMB. The location of deep basement lies along the inferred trend of the Ogasawara Fracture Zone but may also be associated with flexural depression of the lithosphere due to the loading effects of surrounding seamounts. The onset of velocities and velocity gradients characteristic of oceanic crust correspond to the Horizon B reflection imaged throughout both basins. B) Velocity versus depth below seafloor of individual profiles for sonobuoys $4 \mathrm{~m}, 6 \mathrm{~m}$ and 22 all located within $45-90 \mathrm{~km}$ of Site 801 . The nearly identical velocity-depth profiles derived for these sonobuoys provide the best estimate of seismic structure for Jurassic oceanic crust penetrated at Site 801 in the PB. C) Velocity versus depth below the top of Horizon B in the PB and EMB compared to the bounds of "normal" oceanic crust given by White [1984]. 

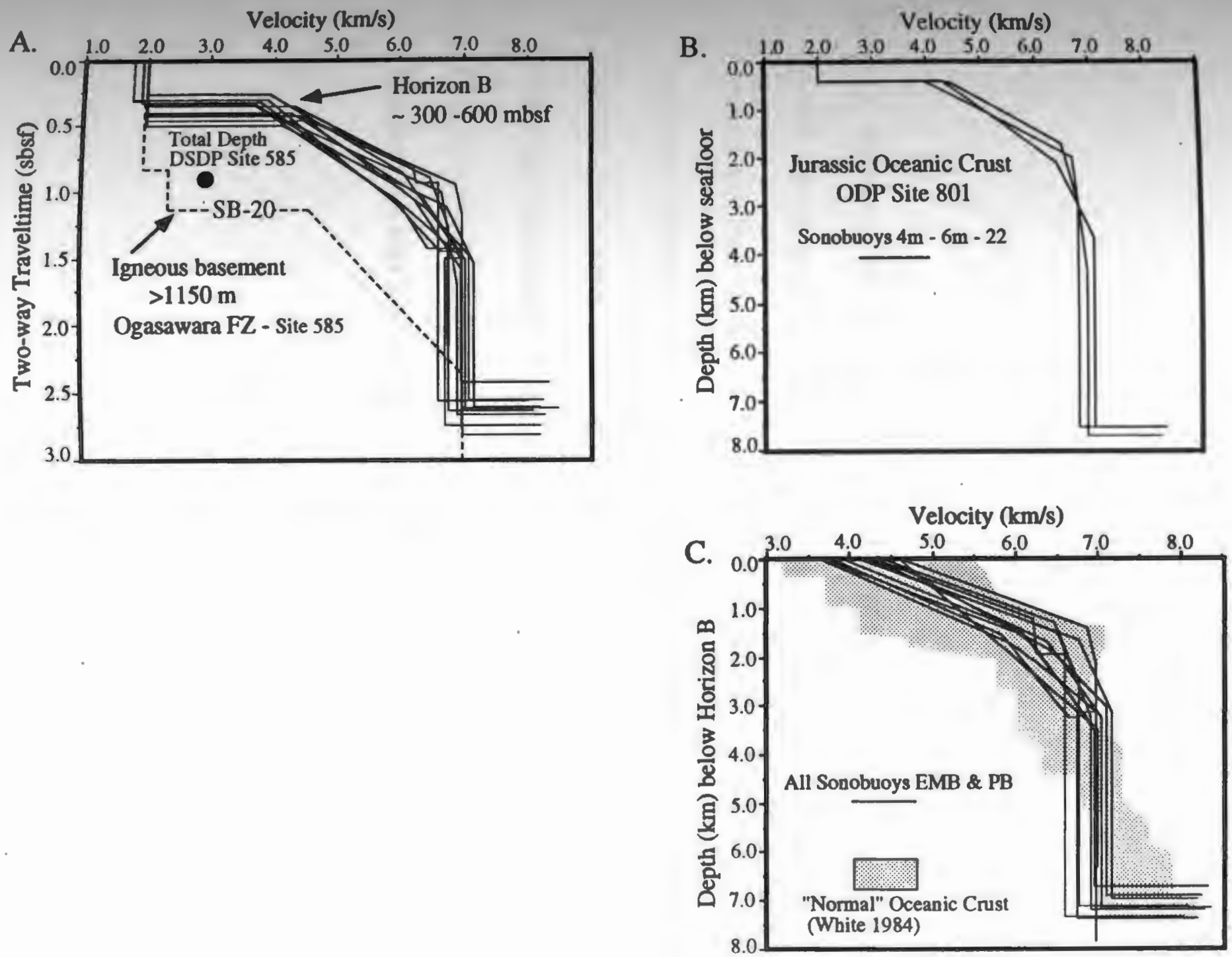
Figure 12. FM35-12 MCS airgun profile in the JQZ of the PB with the velocity-depth profile derived from sonobuoy 22 superimposed. The onset of velocities and velocity gradients characteristic of oceanic crust correspond to the Horizon B reflection. Sonobuoy $22,6 \mathrm{~m}$ and $4 \mathrm{~m}$ all located within $45-90 \mathrm{~km}$ of Site 801 provide nearly identical velocity-depth profiles including wide angle mantle reflections with intercept times matching those observed in the MCS profile labeled MOHO at $~ 10.2$ stwt. Processing and display parameters are the same as in Figure 6 except band-pass filter $8-25 \mathrm{~Hz}$ and vertical exaggeration of $\sim 30 \mathrm{X}$ at $1.5 \mathrm{~km} / \mathrm{s}$. 


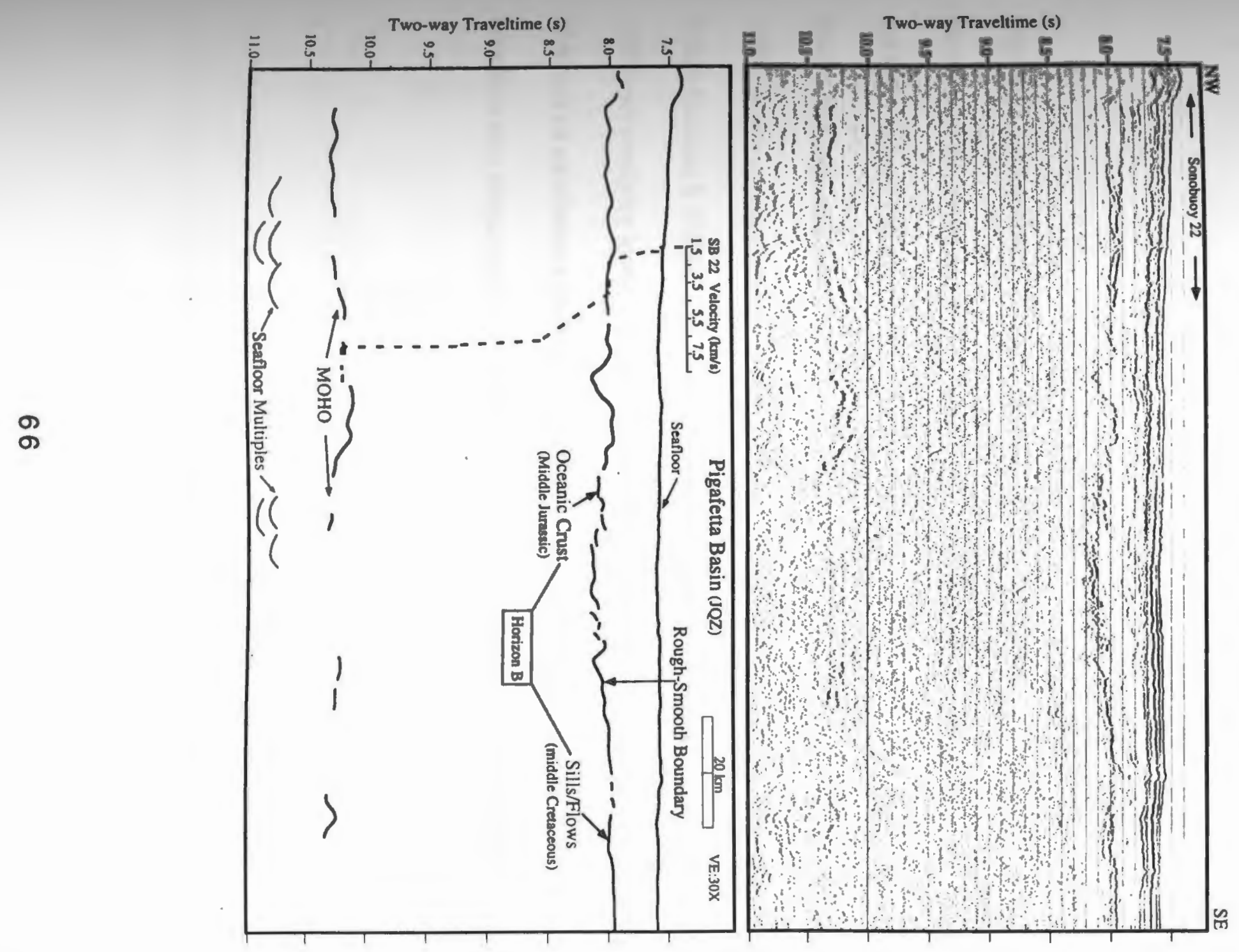


Figure 13. a) Sonobuoy 8 in the JQZ of the EMB located $120 \mathrm{~km}$ North of Site 802 is shown over the entire range of the sonobuoy $(>35 \mathrm{~km})$. b) Sonobuoy 18 in the JQZ of the EMB located $130 \mathrm{~km}$ Northeast of Site 802 is shown over $0-15 \mathrm{~km}$ range. Note the lower amplitude, shallow first refracted arrival with a phase velocity of $5.3 \mathrm{~km} / \mathrm{s}$ (labeled "sill") which appears tangent to the Horizon B reflection (SB18) or to reflections just below Horizon B (SB8). This short range arrival is indicative of a high velocity layer (sill/flow) overlying lower velocity sediment and oceanic crust. Similar arrivals are not observed on sonobuoys northwest of the rough/smooth boundary (compare to Figure 10). Sonobuoy data displayed at reduced travel time $(7 \mathrm{~km} / \mathrm{s})$, band-pass filter $8-25 \mathrm{~Hz}$. 


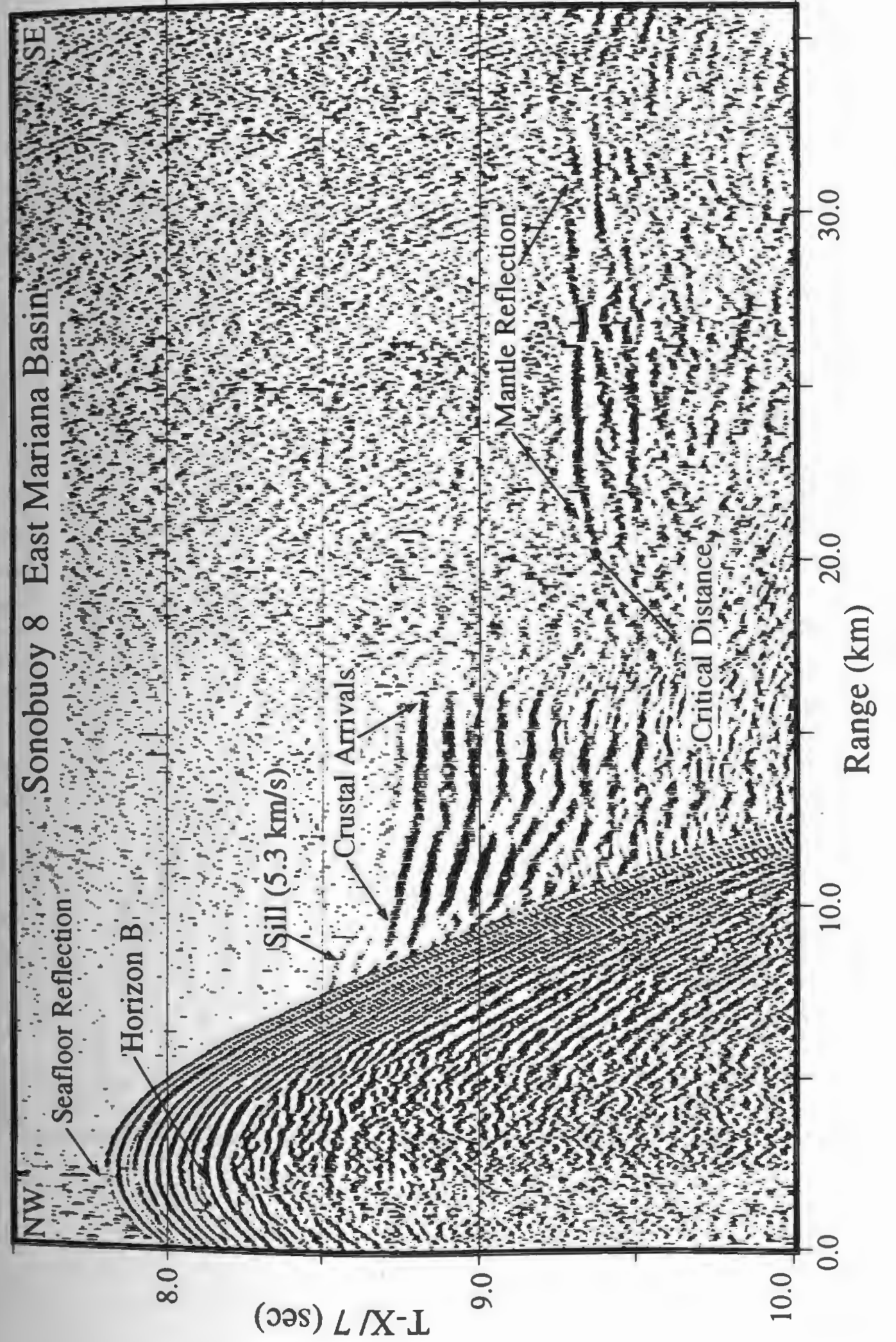




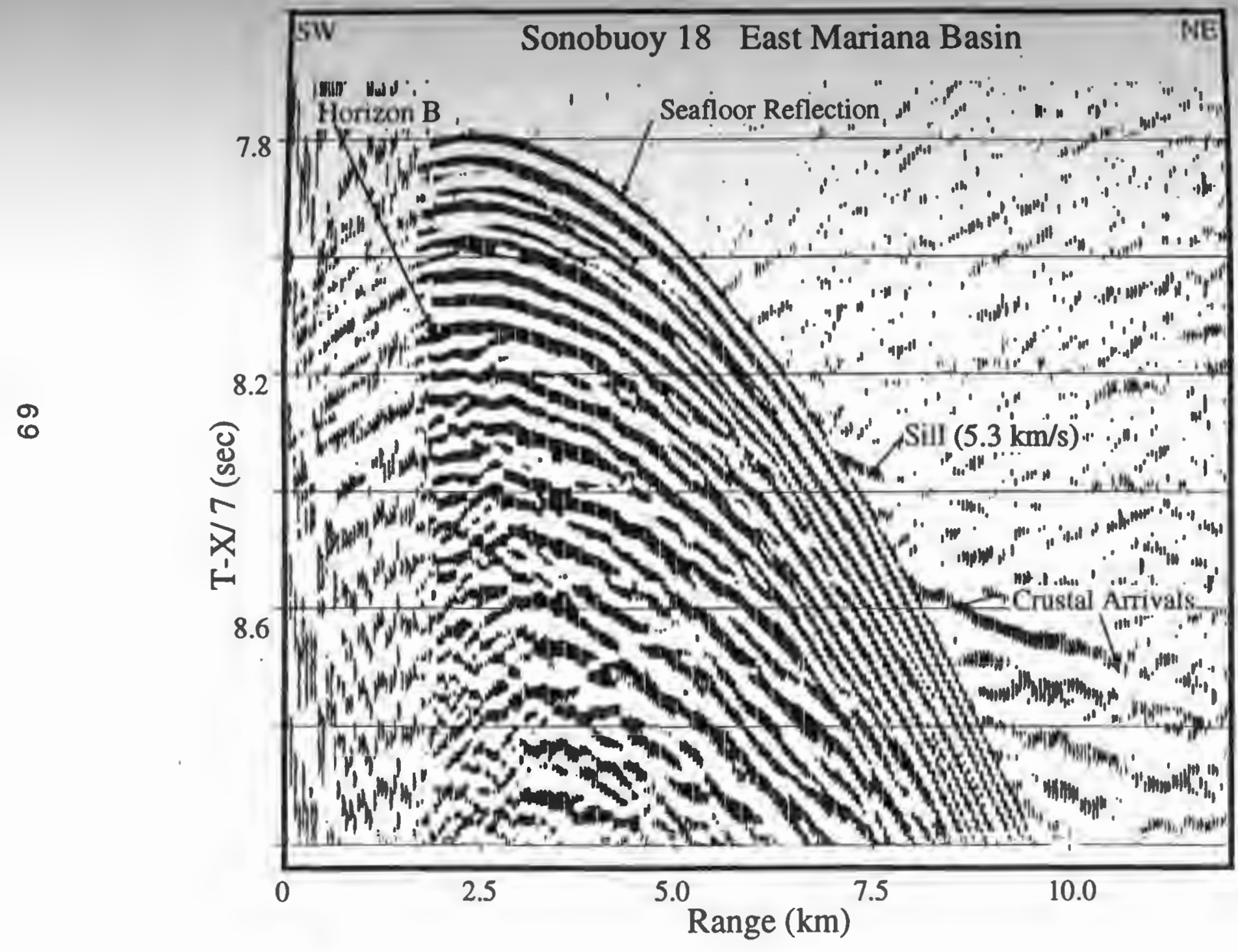




\section{REFERENCES}

Abrams, L.J., R.L. Larson, T. Shipley and Y. Lancelot, Cretaceous volcanic sequences and Jurassic(?) crust in the western Pacific, Eos ,Trans. AGU, 69, 1442, 1988.

Abrams, L.J., R. L. Larson, T. Shipley and Y. Lancelot, The seismic stratigraphy of the East Mariana and Pigafetta Basins of the western Pacific, Proc. ODP Sci. Res., 129, in press.

Asada, T., H. Shimamura, S. Asano, K. Kobayashi, and Y. Tomoda, Explosion seismological experiments on long-range profiles in the Northwestern Pacific and the Marianas Sea, The Ocean Basins and Margins, Vol. 7A, A.E.M. Nairn, Stehli, S. Uyeda, eds., 1985.

Batiza, R., Lithospheric age dependence of off-ridge volcano production in the North Pacific, Geophys. Res. Lett., 8, 853-856, 1981.

Brenner, C. and M. Angell, Bathymetric map of the East Mariana and Pigafetta Basins in the western Pacific, Proc. ODP, Sci. Res., 129, in pres 
Castillo, P. R., and R. W. Carlson, Possible origin of widespread Cretaceous volcanism in the Pacific: constraints from $\mathrm{Sr}, \mathrm{Nd}$, and $\mathrm{Pb}$ isotope geochemistry of Nauru Basin thoeliites, EOS,Trans. AGU, 71, 1667, 1990.

Castillo, P. R., and M. S. Pringle, Cretaceous volcanism in the westem Pacific sampled at Sites 800 and 802, ODP Leg 129, EOS, Trans. AGU, 72, 300, 1991.

Castillo, P. R., P. A., Floyd, and C, France-Lanord, Isotope geochemistry of ODP Leg 129 basalts: implications for the origin of widespread volcanic event in the Pacific, Proc. ODP Sci. Res., 129, in press.

Clague, D. A., R. T. Holcomb, J. M. Sinton, R. S. Detrick, and M. E. Torresan, Pliocene and Pleistocene alkalic flood basalts on the seafloor north of the Hawaiian islands, Earth Planet. Sci. Lett., 98, 175-191, 1990.

Courtillot, V.E., J. Besse, D. Vandamme, R. Montigny, J.J. Jeager, and H. Cappetta, Deccan flood basalts at the Cretaceous/Tertiary boundary?,Earth Planet. Sci. Lett., $80,361-374,1987$.

Diebold, J. B., and P. L. Stoffa, The traveltime equation, tau-p mapping and inversion of 
common mïpoint data, Geophysics, 46, 238-254, 1981.

Diebold, J. B., P. L. Stoffa, P. Buhl, and M. Truchan, Venezuela Basin Crustal Structure, J. Geophys. Res., 86, 7901-7923, 1981.

Edgar, N. T., and J. B. Saunders et al., Init. Repts. DSDP, 15: pp. 1137, 1973.

Ewing, J., M. Talwani, M. Ewing, and T. Edgar, Sediments of the Caribbean, in International Conference on Tropical Oceanography Proc., 5, 88-102, Univ. of Miami, Miami, Fla., 1967.

Ewing, J., M. Ewing, T. Aitken, and W.J. Ludwig, North Pacific sediment layers measured by seismic profiling, in The Crust and Upper Mantle of the Pacific Area, Drake, C.L. and P.J. Hart, eds., AGU Monogr. Ser. vol. 12, AGU, Washington, D. C., 147-173, 1968.

Ewing, J. I., and G. M. Purdy, Upper crustal velocity structure in the ROSE area of the East Pacific Rise, J.Geophys. Res., 87, 8397-8402, 1982.

Hamilton, E. L., Sunken islands of the Mid-Pacific Mountains, Geol. Soc. Am. Mem, 
64, pp. 97, 1956.

Handschumacher, D. W., W. W. Sager, T. W. C. Hilde, and D. R. Bracey, Pre-Cretaceous tectonic evolution of the Pacific plate and extension of the geomagnetic polarity reversaltime scale with implications for the origin of the Jurassic "Quiet Zone", Tectonophysics, 155, 365-380, 1988.

Harland, W. B., R. L. Armstrong, A. V. Cox, L. E. Craig, A. G. Smith, D. G. Smith, A geologic time scale 1989, Cambridge Univ. Press, Cambridge, UK, 263 p., 1990.

Heezen, B.C., I.D. MacGregor, et al., Mesozoic chalks beneath the Caroline abyssal plain: DSDP Site 199, Init. Repts. DSDP, 20, 65-85, 1973.

Hilde, T. W. C., Isezaki, N., and Wageman, J.M., Mesozoic seafloor spreading in the North Pacific, In Sutton, G.H., M. H. Manghnani, and R. Moberly, eds., The Geophysics of the Pacific Ocean Basin and its Margins, AGU Geophys. Monogr. Ser., vol. 19, 205-226, 1976.

Houtz, R. E., J. Ewing, and P. Buhl, Seismic data from sonobuoy stations in the 
northem and equatorial Pacific, J. Geophys. Res., 75, 5093-5111, 1970.

Houtz, R., and J. Ewing, Upper crustal structure as a function of plate age, J. Geophys. Res., 81, 2490-2498, 1976.

Houtz, R. E., and W. J. Ludwig, Structure of Columbia Basin, Caribbean Sea, from profiler-sonobuoy measurements, J. Geophys. Res., 82, 4861-4868, 1977.

Houtz, R.E., and W.J. Ludwig, Distribution of reverberant subbottom layers in the southwest Pacific basin, J. Geophys. Res., 84, 3497-3505, 1979.

Hutchinson, D. R., and R. S. Detrick, Water gun vs air gun: a comparison, Mar. Geophys. Res., 6, 295-310, 1984.

Kroenke, L. W., and W. H. Berger et al., Proc. ODP Init. Repts., 130: College Station, TX (Ocean Drilling Program), pp. 1240, 1991.

Lancelot, Y., and R. L. Larson et al., Proc. ODP Init. Repts., 129: College Station, TX (Ocean Drilling Program), pp. 488, 1990. 
Larson, R.L. and C. G. Chase, Late Mesozoic evolution of the western Pacific Ocean, Geol. Soc. Am. Bull., 83: 3627-3644, 1972

Larson, R. L., R. Moberly, et al., Init. Repts. DSDP, 32: pp. 980, 1973.

Larson, R. L., Late Jurassic and Early Cretaceous evolution of the western central Pacific Ocean, J. Geomag. Geoelectric., 28, 219-236, 1976.

Larson, R.L., S. O. Schlanger, et al., Init. Repts. DSDP, 61: pp. 885, 1981.

Larson, R. L., Latest pulse of the Earth: Evidence for a mid-Cretaceous super plume, Geology, 19, 547-550, 1991a.

Larson, R. L., Geologic consequences of super plumes, Geology, 19, 963-966, 1991 b.

Larson, R. L., and W. W. Sager, Skewness of magnetic anomalies M0 to M29 in the northwestern Pacific, Proc. ODP Sci. Res., 129, in press

Lincoln, J. M., M. S. Pringle, and I. Primoli Silva, Early and Late Cretaceous volcanism and reef-building in the Marshall Islands: new fossil evidence and ${ }^{40} \mathrm{Ar} / 39 \mathrm{Ar}$ ages, 
In Pringle, M., and W. Sager (Eds.) The Mesozoic Pacific, AGU Monogr. Ser., in press

Lipman, P. W., D. A. Clague, and R. T. Holcomb, South arch volcanic field - newly identified young lava flows on the sea floor south of the hawaiian ridge, Geology, $17,611-614,1989$.

Lowrie, A., C. N. Smoot, and R. Batiza, Are oceanic fracture zones strong or weak? New evidence for volcanic activity and weakness, Geology, 14, 242-245, 1986.

Macdonald, K. C., Mid-ocean ridges: Fine scale tectonic, volcanic and hydrothermal processes within the plate boundary zone, Ann. Rev. Earth Planet. Sci., 10, 155-190, 1982.

Mahoney, J. J., and J. A.Tarduno, Cretaceous volcanism and the formation of the Ontong-Java plateau: new insights from ODP Leg 130, EOS,Trans. AGU, 71 , $1668,1990$.

Mammerickx, J., and G.F. Sharman, Tectonic evolution of the North Pacific during the Cretaceous quiet period, J. Geophys. Res., 93, 3009-3040, 1988. 
Menard, H. W. Marine Geology of the Pacific. New York, NY: McGraw Hill Book Co., 1964.

Moberly, R., and S. O. Schlanger et al., Init. Repts. DSDP, 89, pp. 678, 1986.

Nakanishi, M., K. Tamaki, and K. Kobayashi, Mesozoic magnetic anomaly lineations and seafloor spreading history of the northwestern Pacific, J. Geophys. Res., 94, $15,437-15,462,1989$.

Nakanishi, M., K. Tamaki, and K. Kobayashi, Magnetic anomaly lineations from Late Jurassic to Early Cretaceous in the west-central Pacific Ocean,Geophys. J. Int., in press.

Ozima, M., I. Kaneoka, K. Saito, M. Honda, M. Yanagisawa, and Y. Takigami, Summary of geochronological studies of submarine rocks from the western Pacific Ocean, in Geodynamics of the western Pacific-indonesian region, V.11, T .W .C. Hilde, S. Uyeda, eds., 137-142, 1983.

Pringle, M. S., Radiometric ages of basaltic basement recovered by ODP Leg 129, Proc. 
ODP Sci. Res., 129, in press.

Pringle, M., Geochronology and petrology of the Musicians Seamounts and the search for hot spot volcanism in the Cretaceous Pacific, (Ph.D. dissertation), University of Hawaii, Honolulu, 1992.

Purdy, G. M., The seismic structure of 140 my old crust in the Central Atlantic Ocean, Geophys. J. R. Astron. Soc., 72, 115-138, 1983.

Raitt, R. W., The Crustal Rocks, in The Sea, vol. 3, N. M. Hill, ed., John Wiley \& Sons, New York, pp. 85-102, 1963.

Schlanger, S. O., H. C. Jenkyns, and I. Premoli-Silva, Volcanism and vertical tectonics in the Pacific basin related to global Cretaceous transgressions, Earth Planet. Sci. Lett., 52, 435-449, 1981.

Schlanger, S. O., J. F. Cambell, and M. W. Jackson, Post-Eocene subsidence of the Marshall Islands recorded by drowned atolls on Harrie and Sylvania Guyots, in Seamounts, Islands, and Atolls, B. H. Keating, P. Fryer, R. Batiza, and G. Boehlert, eds., AGU Monogr. Ser. v. 43, AGU, Washington D.C., 165-174, 
1987.

Schubert, G., and D. Sandwell, Crustal volumes of the continents and of oceanic plateaus and continental submarine plateaus, Earth Planet. Sci. Lett., 92, 234-246, 1989.

Shipley, T. H., J. M. Whitman, F. K. Duennebier, and L. D. Peterson, Seismic stratigraphy of the East Mariana Basin, western Pacific, Earth Planet. Sci. Lett., 64, 257-275, 1983.

Shipley, T. H., L. J. Abrams, R.L. Larson, and Y. Lancelot, Extent of Cretaceous volcanic sequences in the Jurassic Nauru Basin, In Pringle, M., and W. W. Sager (Eds.) The Mesozoic Pacific, AGU Monogr. Ser., in press.

Smith, W.H.F., H. Staudigel, A.B. Watts, and M. Pringle, The Magellan Seamounts: Early Cretaceous record of the South Pacific isotopic and thermal anomaly, $J$. Geophys. Res., 94, 10,501-10,523, 1989.

Spudich, P., and J. A. Orcutt, A new look at the seismic velocity structure of the oceanic crust, Rev. Geophys. Space Phys., 18, 627-645, 1980. 
Steiner, M., J. Ogg, and J. Sandoval, Jurassic magnetostratigraphy, 3. BathonianBajocian of Carcabuey, Sierra Harana and Campillo de Arenas (Subbetic Cordillera southern Spain), Earth Planet. Sci. Lett., 82, 357-372, 1987.

Talwani, M., C. C. Windisch, P. L. Stoffa, P. Buhl, and R. E. Houtz, Multi-channel seismic study in the Venezuelan Basin and the Curacao ridge, In Island Arcs, Deep Sea Trenches and Back-Arc Basins, AGU Monogr. M. Ewing Ser. vol. 1, M. Talwani, and W. C. Pitman, eds., 83-98, 1977.

Tamaki, K. and R.L. Larson, The Mesozoic tectonic history of the Magellan microplate in the Western Central Pacific, J. Geophys. Res., 93, 2857-2874, 1988.

Tamaki, K., M. Nakanishi, K. Sayanagi and K. Kobayashi, Jurassic magnetic anomaly lineations of the Western Pacific and the origin of the Pacific plate, EOS, Trans. AGU, 68, 1493, 1987.

Tarduno, J. A., W. V. Sliter, L. Kroenke, M. Leckie, H. Mayer, J. J. Mahoney, R. Musgrave, M. Storey, and E. L. Winterer, Rapid formation of the Ontong-Java Plateau by Aptian mantle plume volcanism, Science, 254, 399-403, 1991. 
Vogt, P. R., Volcano spacing, fractures and thickness of the lithosphere, Earth Planet. Sci. Lett., 21, 235-252, 1974.

Weissel, J.K. and R.N. Anderson, Is there a Caroline plate?, Earth Planet. Sci. Lett., $4 l$, 143-158, 1978.

Wipperman, L. K., R. L. Larson, and D. M. Hussong, The geological and geophysical setting near site 462, Init. Repts. DSDP, 61, 763-770, 1981.

Winterer, E. L. et al., Site 61, Init. Repts. DSDP, 7, 27-48, 1971.

Winterer, E. L., and J. Ewing et al., Init. Repts. DSDP, 17:, pp. 930, 1973.

Winterer, E. L., Anomalies in the tectonic evolution of the Pacific, InThe Geophysics of the Pacific Ocean Basin and its Margin, AGU Monogr. Ser. vol. 19, G. H. Sutton, M. H. Manghnani, and R. Moberly, eds., AGU, Wash., D.C., 269-278, 1976.

Winterer, E. L., Duncan, R. A., McNutt, M. K., Natland, J. H., Premoli Silva, Isabella, Sager, W. W., Sliter, W. V., Van Waasbergen, R., and Wolfe, C. J., Cretaceous 
guyots in the northwest Pacific: An overview of their geology and geophysics, In Pringle, M., and W. Sager (Eds.) The Mesozoic Pacific, AGU Monogr. Ser,, in press

White, R. S., Oceanic upper crustal structure from variable angle seismic reflection refraction profiles, Geophys. J. R. astr. Soc., 57, 683-726, 1979.

White, R. S., Atlantic oceanic crust: seismic structure of a slow-spreading ridge, In Ophiolites and Oceanic Lithosphere, Gass I. G., S. J. Lippard and A. W. Shelton, eds., Geol. Soc. London, 101-111, 1984. 


\section{MANUSCRIPT II}

Seismic Stratigraphy and Sedimentary History of the

East Mariana and Pigafetta Basins of the western Pacific 


\section{ABSTRACT}

The successful completion of $\operatorname{Leg} 129$, resulting in the first and only holes to penetrate igneous basement (not necessarily layer 2) in the East Mariana and Pigafetta basins now allows the calibration of our regional multichannel seismic site surveys and the extrapolation of drilling results throughout these oldest Pacific basins. Our study indicates that mid-Cretaceous flows/sills overlie Jurassic/ Early Cretaceous sediments and oceanic crust throughout the East Mariana Basin and the southeast Pigafetta Basin. Jurassic age oceanic crust and overlying Upper Jurassic - Lower Cretaceous sediments unquestionably exist at Site 801 and extend semicontinuously between Sites 801 and 800 . Turbidite sequences of varying thicknesses and ages are ubiquitous features of both basins. Cretaceous turbidite sequences were derived from Magellan and Marcus-Wake seamounts and seamount chains of Aptian age or younger. The seamounts/atolls of the Caroline Ridge more than $300 \mathrm{~km}$ to the south of Site 802 were the source of extensive Mioceneage volcanogenic turbidites which are restricted to the south-central East Mariana Basin, while the carbonate caps that developed on Ita Mai Tai Guyot and other edifices of the Magellan chain were the source for the redeposited shallow-water carbonate sequences recovered along the eastern margin of the East Mariana Basin. The Ogasawara Fracture Zone, Magellan Seamounts, and associated flexural moat separate the Pigafetta Basin from the East Mariana Basin and influence the source and distribution of redeposited material. A distinct basinwide reflection that is correlated with the shallowest chert/porcellanite/clay and chert/chalk sequences in the Pigafetta Basin and East Mariana Basin, respectively, is a 
time-transgressive horizon (Eocene - Campanian) resulting from the passage of the Pacific Plate beneath the equatorial zone of high productivity.

\section{INTRODUCTION}

The correlation of Mesozoic magnetic anomaly sequences in the Pacific Ocean by Larson and Chase (1972), Hilde et al. (1976) and Larson (1976) indicate that the world's oldest in situ ocean crust lies centered in the far western Pacific, and that isochrons become younger in approximately radial fashion. The most recent magnetic anomaly identifications of Tamaki et al. (1987), Handschumacher et al. (1988), Nakanishi et al. (1989), and Nakanishi et al. (in press) indicates that the oldest portion of this plate tectonic pattern is revealed in the East Mariana Basin (EMB) and Pigafetta Basin (PB). Simple extrapolation of spreading rates from post-M25 anomalies indicates that these basins may contain oceanic crust as old as 175 m.y. (Middle-Jurassic) (Figs. 1 and 2, back-pocket plate1- Brenner and Angell this volume).

The inference of Jurassic sediments and basement rocks within the M17 isochron, which encompasses an area equal in size to the contiguous United States, is based entirely on these magnetic lineation correlations. No Jurassic material had been recovered from this region until Ocean Drilling Program (ODP) Leg 129 (November-January 1989-90), despite eight prior scientific drilling expeditions since 1969, and numerous dredging expeditions ranging back to the 1950 s. The oldest material sampled has almost invariably 
been of middle to Late Cretaceous age, consisting of chert, chalk, rudists, dolerite sills, basaltic flows, or volcanogenic sediments.

Two technological factors in past geological and geophysical research in the western Pacific have hindered our understanding of the seismic stratigraphy of the EMB and PB, and of deep sea volcanism in particular. The first is that previous low-volume airgun single-channel seismic (SCS) and sonobuoy experiments were unable to adequately define stratigraphic relationships in the western Pacific. The second was the inability to penetrate beneath the Cretaceous sequences described above with the Glomar Challenger's drilling system and less than optimum drill siting because of the inadequate seismic data.

Seismic reflection studies of the EMB and PB presented in this paper imaged oceanic crust, mapped the overlying strata, and identified a site where the IOIDES Resolution was able to recover Jurassic to Tertiary sediments during Leg 129 (Abrams et al., 1988; Lancelot, Larson et al., 1990). The successful completion of Leg 129 resulted in the first and only holes to penetrate the complete sedimentary sequence overlying igneous basement (not necessarily layer 2) in the EMB and PB. This paper utilizes the seismic reflection data to investigate the basinwide distribution, variability and sources of the sedimentary sequences sampled during Leg 129 and selected DSDP Legs in the area.

\section{DATA ACQUISITION AND PROCESSING}

In November - December 1987 the research vessel Fred H. Moore expedition 35-12 
(FM35-12) collected over $3900 \mathrm{~km}$ of multichannel seismic (MCS) data using a 3200-mlong receiving array consisting of 96 hydrophone groups each $33.33 \mathrm{~m}$ in length (Fig. 3). The seismic data were demultiplexed and recorded on a GUS 4200 Marine System sampling at $4 \mathrm{~ms}$. The Moore's seismic source consisted of various combinations of airguns shot at approximately $13.8 \mathrm{MPa}(2000 \mathrm{psi})$ every $20 \mathrm{~s}$. The maximum airgun volume achieved was 84.15 liters (5135 in 3 ) but the mean airgun volume during the 17 days of MCS acquisition was $40.65 \mathrm{~L}$ (2481 in3). Refraction data collected by seven longrange sonobuoys were also digitally recorded during this regional survey (Abrams et al., in press). The MESOPAC I MCS survey conducted with the Le Suroit during August September 1989 focused on potential drilling targets first identified on FM35-12, as well as investigating the northern PB within the oldest portion of the M-sequence lineation pattern. Only processed near channel data from MESOPAC II are used in this study. The MESOPAC II expedition also recorded approximately $3900 \mathrm{~km}$ of MCS data using an array of four to six 1.31-L (80 in 3 ) waterguns fired every $13 \mathrm{~s}$ during vertical incident profiling and two $16.39-\mathrm{L}$ (1000 in 3 ) airguns fired every $31 \mathrm{~s}$ while digitally recording refraction data from six long-range sonobuoys. Seismic signals were received by a 2400 m-long array consisting of 96 hydrophone groups each $25 \mathrm{~m}$ in length. The MESOPAC II expedition also acquired high-quality $3.5-\mathrm{kHz}$ records which were used as a final constraint for Leg 129 site locations.

During both cruises the ships maintained a speed of approximately 5 to 6 knots and 
navigated primarily by Transit satellite but also by NAVSTAR global positioning system (GPS) with coverage of approximately 5 hours a day. Shot spacing was calculated for the FM35-12 data using final navigation along individual lines, and for MESOPAC II SCS watergun data was estimated at $40 \mathrm{~m}$ per shot. FM35-12 common depth point (CDP) gathers were created with 66.66-m bin size, $33.33 \mathrm{~m}$ hydrophone group spacing with variable shot spacing $(-50 \mathrm{~m} / \mathrm{shot})$, resulting in up to 120 fold gathers. Stacking velocities from the seafloor to Horizon B were derived from semblance analysis of four adjacent CDP gathers at selected areas along each line and sub-Horizon B stacking velocities were derived from sonobuoy results.

\section{TECTONIC SETTING AND REGIONAL HISTORY}

The EMB and PB are defined as the area $\left(-1 \times 10^{6} \mathrm{~km}^{2}\right)$ in our region of study where depths exceed $5500 \mathrm{~m}$ (Fig. 2) (Brenner and Angell, this volume). The EMB is bounded to the west-northwest by the Mariana Trench, to the southwest by the Caroline Ridge, and to the northeast by the northwest trending Ogasawara Fracture Zone and Magellan Seamounts (Tamaki et al., 1987; Handschumacher et al., 1988) (Figs. 1 and 2). The PB is bounded to the northeast by the Kashima Fracture Zone and Marcus-Wake Seamounts and to the southeast by the Ogasawara Fracture Zone and Magellan Seamounts and extends to the northwest, where it terminates at the Bonin Trench.

In this paper age is assigned according to the geologic time scale of Harland et al. 
(1990). The available magnetic and seismic data suggest that the PB and EMB are underlain by oceanic crust of Late Jurassic to probably Middle Jurassic age (Figs. 1 and 2). The central parts of these basins are predicted to be Oxfordian to Callovian (anomalies M29 to M36 - 157-162 Ma) and toward the southeast, within the Jurassic magnetic quiet zone (JQZ), the age of the crust may be as old as Bathonian to Bajocian (Middle Jurassic, 161-174 Ma). An alternative interpretation for the oldest anomalies in the EMB, as shown in Figure 2, is that they are symmetric about an abandoned spreading center at M32 time. Either interpretation would predict that Jurassic oceanic crust at Site 802 is older than M35 and younger than crust recovered at Site 801 ( 161-167 Ma). Nakanishi et al. (1989) calculate half-spreading rates of $64 \mathrm{~mm} / \mathrm{yr}$ for the oceanic crust formed in the PB between M21 and M25 using the time scale of Kent and Gradstein (1985) or $78 \mathrm{~mm} / \mathrm{yr}$ using Harland et al. (1990). The thoeliitic basalt recovered at Site 801 in the JQZ has been dated at $166.8+/-4.5 \mathrm{Ma}$ by whole rock $40 \mathrm{Ar} / 39 \mathrm{Ar}$ incremental heating analysis (Pringle, this volume). A crustal age of $167 \mathrm{Ma}$ at Site 801 results in pre-M25 half-spreading rates of approximately $80 \mathrm{~mm} / \mathrm{yr}$ assuming constant rates of spreading and an M25 date of 155 Ma (Harland et al., 1990). This spreading rate is comparable to the fastest half-spreading rates presently documented on the East Pacific Rise (80 - 90 mm/yr, MacDonald, 1982).

Reconstruction models of Pacific Plate motion, based on various references such as hotspot traces, paleomagnetism, magnetic anomaly skewness, and the sediment record of equatorial crossings, all indicate a general northward movement from southern to northern 
latitudes from the Late Cretaceous to Holocene (Lancelot and Larson, 1975; Jarrard and Clague, 1977; Sager and Pringle, 1988; Larson and Sager; Steiner and Wallack, both this volume ). Larson and Lowrie (1975) suggested that the plate moved from north to south during the latest Jurassic-earliest Cretaceous and thus might have crossed the equator twice. Paleomagnetic measurements of $\mathrm{Leg} 129$ samples (Steiner and Wallick, this volume) and magnetic skewness analysis (Larson and Sager, this volume) indicate that the majority of the Pacific Plate (including Leg 129 sites) was south of the equator in the latest Jurassic but that its earliest motion did indeed have a southward component.

The latitudinal plate motion described above and the vertical motion caused by the subsidence of the plate as it cools with age influence the accumulation and distribution of pelagic sediments. The huge output of mid-plate volcanism during the middle-Cretaceous, and a much smaller volume during the Tertiary, however, had the greatest influence over the subsidence history and the type, distribution, and volume of material delivered to these basins.

\section{WESTERN PACIFIC SEISMIC STRATIGRAPHY}

The seismic stratigraphy of large portions of the western Pacific including the PB and EMB consists of four units originally defined by Ewing et al. (1968): (1) an upper transparent layer (weakly reflective), (2) an upper opaque layer (highly reflective and /or twell-stratified), (3) a lower transparent layer, and (4) Horizon B. 
Early Deep Sea Drilling Project (DSDP) investigations (e.g., Legs 6, 7, 17, 20) revealed the lithostratigraphic significance of the upper transparent and opaque layers in the western Pacific. The upper opaque layer has been correlated to the uppermost abundant chert in much of the North Pacific and the upper transparent layer has been recognized to correspond to a variety of lithofacies: pelagic clay in the west/central Pacific, turbidite sequences in the north and east, and biogenic oozes along the equator. Before DSDP Leg 32 there was little direct knowledge of the lower transparent seismic unit and Horizon B in the oldest portions of the Pacific, and it was not until Leg 129 that these two deepest seismic facies were directly sampled in the EMB and PB.

This paper will concentrate primarily on sedimentary stratigraphy overlying the Horizon B reflection within the EMB and PB and will emphasize the correlation of seismic and lithostratigraphy using the drilling results from Leg 129. A full description of basinwide variability of crustal stratigraphy, including Horizon B, is presented in Abrams et al. (in press).

\section{Leg129 Site Review}

At the sites drilled during Leg 129 we penetrated and recovered material correlated to all four general seismic units of Ewing et al. (1968), including Horizon B. The seismic stratigraphy at Leg 129 Sites is summarized in Figure 4A-C.

Site 801 , located in the southeast PB, was the first and so far only location where Jurassic sediments and oceanic crust have ever been recovered in the Pacific. The oldest 
sediments recovered were claystone/radiolarite (Callovian-Bathonian, $\sim 157$ - $166 \mathrm{Ma}$ ). Horizon B at 462 meters below seafloor (mbsf) corresponds to the top of oceanic crust, radiometrically dated at $\sim 167 \mathrm{Ma}$, and is overlain by Middle Jurassic to Early Cretaceous pelagic sediments (radiolarite/clay) beneath a thick sequence of volcanogenic turbidites deposited after mid-Valanginian time through the Albian-Cenomanian ( 135-97 Ma). Site 800, located in the northwest PB, reached Horizon B at 498 mbsf. Horizon B corresponds to dolerite sills radiometrically dated at $\sim 120$ Ma below earliest Cretaceous pelagic sediments and a thick sequence of Aptian (112-124.5 Ma) volcanogenic turbidites. Site 802 in the EMB penetrated Horizon B at 509 mbsf, sampling basalt flows and pillow units, radiometrically dated at $\sim 114 \mathrm{Ma}$, beneath a sedimentary cover that consists almost exclusively of redeposited sediments of Aptian to Pliocene age (124.5 - 5.2 Ma) (radiometric dates from Pringle this volume).

\section{DSDP Site Review}

DSDP Site 585 on the eastern margin of the EMB is located over the anomalously deep trough of the Ogasawara Fracture Zone and reached late Aptian volcanogenic turbidites at $893 \mathrm{mbsf}$, approximately $260 \mathrm{~m}$ short of high-velocity igneous basement (crust or massive volcanism)(Abrams et al., in press). Redeposited volcanogenic and biogenic material dominate the sedimentary section and record the growth, subsidence, and erosion of the surrounding Magellan seamounts from Aptian to Holocene. The uppermost $\sim 485 \mathrm{~m}$ (units I-IV) are considered comparable to the section drilled at DSDP 
Site 199.

DSDP Site 199, located $\sim 75 \mathrm{~km}$ west of DSDP Site 585 in the EMB, terminated at $456 \mathrm{mbsf}$ in brown tuff beneath upper Campanian chalk/clay/chert to upper Paleocene chert/chalk at $285 \mathrm{mbsf}$. The uppermost unit consists of zeolitic clay, microfossil ooze, and a few ash layers all younger than late Oligocene. DSDP Leg 89 investigators (i.e., Site 585) reinterpreted these sediments as turbidites deposited below the CCD along with background pelagic accumulation.

DSDP Site 61, located more than $600 \mathrm{~km}$ due west of Site 802 (Fig. 2), penetrated basalt flows interlayered with Santonian - upper Campanian sediments ( 86 - $80 \mathrm{Ma})$ at 93 mbsf. The basalt correlates to a prominent reflection which overlies a deeper weak event believed to be the top of oceanic crust (Shipboard Scientific Party, 1971). The sediment that overlies basalt consists of minor Late Cretaceous chert, zeolitic clay, and radiolarian ooze of Paleocene to Miocene age and younger zeolite clays and diatom oozes. The available seismic data across DSDP Site 61 is inadequate in quality and coverage, and cannot be correlated with the seismic stratigraphy of most of the EMB.

\section{SEISMIC OBSERVATIONS}

The results of our regional seismic profiles are illustrated in three cross sections across both the EMB and PB (Figs. 5A-C; location in Fig. 3) and are accompanied by several key seismic reflection examples. The cross sections were created by digitizing 
distinctive reflection surfaces which seemed to maintain unique characteristics (i.e., seismic facies) over basinwide distances. The selected horizons include the seafloor, the shallowest abundant chert/porcellanite/clay or chert/chalk, mid-Cretaceous basaltic sills/flows (smooth, flat-lying Horizon B), and the top of Jurassic oceanic crust (rough, high-relief Horizon B). In the EMB the lithofacies significance of these distinct seismic horizons and the intervals which they bound is based on the lithologies recovered at Site 802 (Fig. 4C) in the center of the basin, DSDP Sites 199 and 585 (Fig. 6) on the far eastern edge, as well as DSDP Site 61 at the far western edge, while the more variable seismic stratigraphy of the PB is interpreted from the results of ODP Sites 800 and 801 (Figs. 4A and 4B).

\section{Sediment Velocities}

Sediment velocities, based on velocity analysis of four contiguous CDP gathers from the $3.3 \mathrm{~km}$-long 96 -channel streamer, ranged from 1.6 to $3.0 \mathrm{~km} / \mathrm{s}$ usually increasing with depth. This range in velocities is similar to velocities derived from $T^{2} / X^{2}$ sonobuoy solutions in the northwest Pacific and those measured during DSDP Legs 20, 32, 89 (Heezen, B. C., MacGregor, I. D., et al., 1973; Larson, R. L., Moberly, R., et al., 1975; Moberly, R., Schlanger, S. O. et al., 1986). This range in velocities is also consistent with modeled reflections within the sediment layer from sonobuoys collected during our investigations (Abrams et al., in press).

Average velocities of the intervals bounded by the above horizons are estimated 
from differences in two-way traveltime and drilled thicknesses. The average velocity for the entire sedimentary section above Horizon B is $2.0 \mathrm{~km} / \mathrm{s}$ at both Sites 800 and 801 and $\sim 1.9 \mathrm{~km} / \mathrm{s}$ at Site 802 . Downhole sonic $\log$ measurements (obtained for only a portion of the sedimentary section at each site) indicate systematically higher average velocities and provide constraints on small vertical-scale lithologic variations (Fisher et al., this volume). The average velocities presented here are not used as lithologic discriminants but are useful in determining thickness variations of seismic-lithofacies over lateral scales of 100 to $1000 \mathrm{~km}$.

Horizon B

Horizon B is characterized as a single or two closely spaced, very high-amplitude, typically smooth reflector(s) when imaged with either the FM35-12 airgun or MESOPAC II watergun source. Horizon B often appears as acoustic basement, in that where it is present, deeper reflections are usually not observed with any consistency. This distinct reflective horizon is associated with the onset of high velocities $(>3.8 \mathrm{~km} / \mathrm{s}$ ) (Abrams et al., in press), and we believe it is comparable in acoustic character to the unusually smooth basement observed in parts of the western North Atlantic and Caribbean Basin that was designated as Horizon B" (Ewing et al., 1967; Edgar, Saunders, et al., 1973; Houtz and Ludwig, 1977). In this context, Horizon B will always refer to a high-velocity horizon; its reflection character and stratigraphic position will determine if this horizon is interpreted as the top of sills/flows that overlie true oceanic crust, or Jurassic-age oceanic crust with no such massive igneous overburden. Horizon B can be characterized by two 
end-member modes: 1) as a relatively high-relief (50-100 m over tens of kilometers), lower reflection amplitude, diffractive ("rough") surface which always appears as acoustic basement and is interpreted as the top of oceanic crust, and 2) as a flat-lying, highreflection amplitude, semicontinuous surface which most often appears nondiffractive ("smooth"), does not necessarily appear as acoustic basement, and is interpreted as sills/flows overlying oceanic crust. A map view of the acoustic character of Horizon B and its interpretation is presented along the seismic track lines in Figure 7 and in cross section in Figure 5. These figures indicate that there are extensive areas in the northwest PB where the acoustic character does not clearly fall within the above defined modes and/or these end-member reflection characteristics alternate over distances of only tens of kilometers and as a result these areas have been more tentatively interpreted as the top of oceanic crust with possible sill/flow overburden (Abrams et al., in press). In contrast, Horizon $\mathrm{B}$ throughout the southeast $\mathrm{PB}$ and entire EMB, including the Caroline Ridge, is interpreted as the top of mid-Cretaceous flows and sills which are less than $400 \mathrm{~m}$ thick (probably $\sim 100 \mathrm{~m}$ ) and no older than Aptian (<124.5 Ma). Weak discontinuous reflections $100-150 \mathrm{~ms}$ below Horizon B have been interpreted as the top of Jurassic oceanic crust in the EMB (Abrams et al., in press). Finally, Horizon B at Site 801 unquestionably represents the top of oceanic crust of Jurassic age. Southwest of Site 801 Horizon B becomes markedly flat-lying and smooth. This distinct change in seismic character termed "the rough/smooth boundary" marks the lateral extent of continuous midCretaceous massive igneous units overlying Jurassic oceanic crust and sediment (Fig. 8). 


\section{Lower Transparent Unit}

Immediately overlying Horizon B is the Lower Transparent Unit ( 8.1-8.4 seconds two-way time s TWT at EMB Site 802), which is characterized by low-amplitude, more widely separated and discontinuous reflectors, making this sequence distinctly transparent on both airgun and watergun seismic records (Fig. 4C). These reflections are flat-lying and thin where Horizon B rises (300 mili-seconds below seafloor - [ms bsf]) and appear to onlap the sillflow surface (Horizon B) where it is disrupted by an abrupt offset occurring along the lower slope of the Caroline Ridge south of Site 802 (Fig. 9) which suggests that the Lower Transparent Unit is not dominantly pelagic drape.

The Lower Transparent Unit in the central EMB correlates with the sequence of redeposited late Aptian calcareous claystone and radiolarite penetrated at Site 802 (460 to $509 \mathrm{mbsf}$ ), as well as the lower portion of the Coniacian to Campanian volcaniclastic turbidites (388 to $360 \mathrm{mbsf}$ [Fig. 4C]). The moderate-amplitude reflections that divide the Lower Transparent Unit in half at approximately $8.2-8.3 \mathrm{~s}$ TWT are thought to correspond to the increased occurrence of chert within a chalk dominated sequence overlying a transition zone that contains volcaniclastic turbidites, calcareous claystone and porcellanite of late Campanian to Eocene age. The top of this unit at $200-300 \mathrm{mbsf}$ (Figs. 4C and 5A-C) can be identified basinwide and is correlated to the first chert of similar age at DSDP Site 199 (285 mbsf) and DSDP Site 585 ( $>256 \mathrm{mbsf}$ ). This unit appears to drape onto the immediately surrounding seamounts (Fig. 6) and there is a much greater thickness of Upper Cretaceous to middle Eocene chalk and chert at DSDP Sites 
199 and 585 at the eastern edge of the EMB than at Site 802 (Heezen, MacGregor et al., 1973; Moberly, Schlanger et al., 1986; Lancelot, Larson et al., 1990) (Figs. 5C, 6).

The relatively transparent interval above the first chert at $\sim 8.2 \mathrm{~s}$ TWT and below the onset of high-amplitude reflections at $\sim 8.05 \mathrm{~s}$ TWT corresponds to tuff intercalated with redeposited calcareous claystone and chalk between approximately 167 and $300 \mathrm{mbsf}$ at Site 802 .

In the PB Lower Transparent Unit ranges from 250 to $460 \mathrm{~ms}$ bsf (7.68-8.00 s TWT at Site 801 [Fig. 4B]) and may extend as high as $140 \mathrm{~ms}$ bsf. This layer appears to thin to the southeast of Site 801 as the underlying Horizon B rises in the section and changes to its more typical flat-lying, smooth appearance. The Lower Transparent Unit sometimes includes a distinct high-amplitude, continuous reflection that mimics the underlying relief and appears to be a draping deposit. In the immediate vicinity of Site 801 this high amplitude reflection at $310 \mathrm{~ms}$ bsf appears to divide the Lower Transparent Unit in two (Fig. 4B) and, in other instances, it seems to mark the base of an overlying opaque layer or becomes part of an opaque layer that extends all the way to basement (e.g., left side of Fig. 4B). This variation in acoustic character for the interval directly overlying Horizon B is observed throughout the PB but, in general, the lower transparent layer is best developed where Horizon B is not shallow in the section (e.g., 200-300 ms bsf). It appears most distinct and continuous in the central portion of the JQZ between Site 801 and approximately M36 (Fig. 5A) but is poorly developed along the southwest edge of the PB (right side of Fig. 10). 
The Lower Transparent Unit at Site 801 correlates with the thin $(18 \mathrm{~m})$ sequence of Callovian-Bathonian red radiolarite and claystone and pre-Aptian brown radiolarite (310$453 \mathrm{mbsf}$ ), as well as the lower portion of the Aptian? - Albian volcaniclastic turbidites (about 185 to $310 \mathrm{mbsf}$ ) (essentially depositional stage 1-3 of Karpoff, this volume). The situation at Site 800 is similar; however, the clay/radiolarite pelagic section is much thinner and gives way to volcaniclastic debris flows earlier, in the Aptian (Fig. 4A). The critical difference for Leg 129 investigators is that all the Late Jurassic pelagic deposits, as well as a portion of the Berriasian, are covered/intruded by a dolerite sill in which Site 800 terminated.

The high-amplitude reflection that divides the transparent layer in half at $310 \mathrm{~ms}$ bsf at Site 801 (Fig. 4B) is thought to correspond to an unrecovered, unusually well-lithified horizon -perhaps a massive chert layer or "hard ground" as inferred from an abrupt drilling rate decrease and downhole log response (Shipboard Scientific Party, 1990b). This horizon marks the transition from nonvolcanogenic lithologies below $-318 \mathrm{mbsf}$ (mid-Valanginian) to an overlying sequence dominated by volcanogenic turbidites no older than Aptian (Ogg et al., this volume). The reflection that corresponds to this Early Cretaceous unconformity is tentatively traced $-200 \mathrm{~km}$ northwest of Site 801 and is not noted at Site 800 (Figs. 4A and 5A). To the southeast of Site 801 the Lower Transparent Unit is absent and we expect that volcanogenic turbidites, no older than Aptian age, directly overlie Aptian age sills/flows (Horizon B), which in turn mask Jurassic-Early Cretaceous sediment and oceanic crust. 


\section{Upper Opaque Unit}

In the EMB the sequence from the seafloor down to approximately 100-200 ms bsf is comparable to that described by Ewing et al. (1968) as the "upper opaque layer" (Fig. 4C). This interval contains closely spaced, moderate-to-high amplitude reflections that are traceable for 30 to $50 \mathrm{~km}$. This uppermost unit is distinct in that reflections onlap basement highs, including a large unnamed Magellan seamount to the north and Ita Mai Tai Guyot to the south, and tends to thicken in minor lows and thin over minor highs. This upper unit, however, becomes distinctly transparent on processed FM35-12 airgun records $\sim 250 \mathrm{~km}$ east of Site 802, including the area south of DSDP 199.

In the PB the Lower Transparent Unit is bounded on top by a distinctly higher amplitude, more continuous sequence of reflections that appear to drape over underlying relief. This unit appears to maintain a fairly uniform thickness throughout extended portions of the PB and appears to replace the Lower Transparent Unit altogether where the Aptian age sills/flows (Horizon B) are particularly shallow (e.g. southeastern PB 220 to $300 \mathrm{~ms}$ bsf [right side of Figs. 8 and 10] ). This series of three to four continuous, high-amplitude reflectors is distinguished from the comparable seismic facies in the EMB by the greater continuity of individual reflectors and the fact that the majority of this sequence appears as a draping deposit rather than the basin-filling sequence observed in the EMB. In areas of relatively high relief Horizon B these uppermost reflectors show corresponding, but muted relief (Fig. 4B at 23:25 UTC).

The Upper Opaque Unit in the central portion of the EMB corresponds to mid- 
Pliocene - lower Miocene redeposited tuff and minor interbedded pelagic claystone at Site 802 and maintains a fairly uniform thickness of $150-200 \mathrm{~m}$ throughout the basin (Shipboard Scientific Party, 1990c). The high-amplitude, semi-continuous reflections that characterize this interval are interpreted to arise from impedance contrasts between alternating zones of variably cemented coarse-grained volcanic sandstone and fine-grained volcanic siltstone/claystone. To the south of Site 802 along a MESOPAC II track heading south out of the EMB toward the Caroline Ridge the Upper Opaque Unit (Miocene tuff) thickens and directly, overlies the rising Horizon B (mid-Cretaceous flow/sill). The semicontinuous reflections of the Upper Opaque Unit (Miocene tuff) downlap toward the basin and eventually thin to the nearly constant thickness of $200 \mathrm{~ms}$ observed in the central EMB (Figs. 4A, 5B, 9). Along the eastern margin of the EMB, at Sites 199 and 585, this uppermost seismic unit appears much more transparent and it certainly corresponds to the Tertiary calcareous turbidites that were recovered at DSDP Site 199 and easily washed through at DSDP Site 585 (Figs. 6, 5B and 5C) (Heezen, MacGregor, et al., 1973; Moberly, Schlanger, et al., 1986). The transition from these "soft" calcareous turbidites to the well-indurated tuffaceous volcaniclastic turbidites recovered in the central EMB may be marked by the change in acoustic character (FM35-12 airguns) of the Upper Opaque Unit (i.e., transparent $=$ calcareous to opaque $=$ tuff). In the vicinity of DSDP Site 585 this interval does not thicken and is observed to onlap the middle Eocene chert/chalk reflector as it drapes onto and merges with the surrounding seamounts (Fig. 6 right side). The upper opaque reflections are also observed to onlap the chert/chalk horizon as it rises 
in section ( $<100 \mathrm{~ms}$ bsf) along MESOPAC II line 18 across the eastern margin of the EMB (Fig. 5B). Drilling results from DSDP Sites 59,61, and 452, located on the far western to northwestern margin of the EMB (Fig. 2), indicate that the flat-lying reflections composing the upper opaque unit correlates to chert/porcellanite/clay of Late Cretaceous age.

In the northwest PB the transition from brecciated, poorly bedded debris flows to coarse-grained turbidites, along with the appearance of nannofossils at approximately 351 mbsf, correlates to a change from Lower Transparent to Upper Opaque seismic facies at Site 800 (Fig. 4A) (Shipboard Scientific Party, 1990a). The lowermost section of the Upper Opaque Unit is characterized by the highest amplitude, most continuous reflections that change to lower amplitude, less continuous events up section. The subtle change in seismic character that occurs within the Upper Opaque Unit is clearly correlated to the transition from redeposited volcanogenic material with intervals of high silicon content (about 219 to $300 \mathrm{mbsf}$ ) to a sequence of pelagic carbonate and silica-rich sediments (between 78 and 219 mbsf) (Shipboard Scientific Party, 1990a). The most discontinuous and diffuse (but still high-amplitude) reflections are associated with the Turonian to late Campanian clay/porcellanite/chert sequence between 38 and $78 \mathrm{mbsf}$.

At Site 801 a transition zone that consists of middle to late Albian volcaniclastic turbidites and interbedded pelagic material at approximately 193 mbsf correlates to the relative increase in reflection amplitude that marks the change from Lower Transparent to Upper Opaque seismic facies. These high-amplitude reflections also encompass the 
overlying pelagic interval where impedance contrasts occur between interbedded chert/porcellanite and pelagic clay of Cenomanian to Campanian age (Fig. 4B).

\section{Upoer Transparent Unit}

This acoustically transparent layer is less than $100 \mathrm{~m}$ thick over much of the North Pacific from $15^{\circ}$ to $45^{\circ} \mathrm{N}$ (Ewing et al., 1968). The Upper Transparent Unit in the EMB and PB extends from 0 to approximately $30 \mathrm{~ms}$ bsf at Site 802 and from approximately $100 \mathrm{~ms}$ bsf to less than $30 \mathrm{~ms}$ bsf throughout the majority of the PB. This interval is often absent altogether and appears to be scoured away, and the surrounding thicker accumulations are interpreted as levee deposits. When present, this interval appears to drape over irregularities, mirroring the uppermost high-amplitude reflections of the Upper Opaque Unit. This interval is best displayed on $3.5-\mathrm{kHz}$ records, but is also apparent on SCS and MCS records when thick enough ( $100 \mathrm{~ms})$.

The transparent nature of the uppermost seismic unit is indicative of a relatively homogeneous interval that contains no significant impedance contrasts. This interval correlates to pelagic brown clay (14 m at Site $802,61 \mathrm{~m}$ at Site $801,38 \mathrm{~m}$ at Site 800,72 $\mathrm{m}$ at Site $61,25 \mathrm{~m}$ at Site 452 ). At Site 800 the Miocene pelagic clay lies unconformably over Late Cretaceous chert but at Site 801 there is inadequate biostratigraphic data to identify any possible hiatus between the Tertiary pelagic clay and underlying Late Cretaceous chert. The topmost $30 \mathrm{~ms}$ at Site 802 correspond to the upper Pliocene to Quaternary pelagic brown clay representing slow pelagic deposition and authegenisis below the carbonate compensation depth (CCD) (Lancelot, Larson, et al., 1990). 


\section{DISCUSSION}

\section{inwide Distribution of Sediments Recovered During ODP Leg 129}

Sediment accumulation and distribution are largely controlled by the variation in the seafloor depth through time, temporal changes in the sources for redeposited sediments, and time-varying fluctuations in the CCD. The huge output of mid-plate volcanism primarily during the mid-Cretaceous directly affected the first two of these controls and most likely altered the $\mathrm{CCD}$ in a nonlinear way by at least doubling the atmospheric $\mathrm{pCO}_{2}$ (Arthur et al., 1985, 1991). Thus the mid-Cretaceous volcanic event dominates the sedimentary history of these basins from the latest Barremian - Aptian onward through the Late Cretaceous. Redeposited sediments make up virtually the entire drilled interval at Site 585 and Site 802 in the EMB and represent the majority of the sediment penetrated at Sites 800 and 801 in the PB. The age and stratigraphic relationships derived from the correlation of drilling results with seismic stratigraphy allow us to map the vertical, as well as the lateral extent of these deposits on a basinwide scale.

\section{Thertiary Turbidites of the EMB}

Results from DSDP Sites 199 and 585 led investigators to suspect that the Upper Opaque Unit throughout the central EMB represents turbidites dominated by pelagic components rather than abundant autochthonous chert/clay or chert/chalk as is the case in extended portions of the northwest Pacific. Investigators speculated, based largely on the material's shallow water fossil content and age, that it was derived from the Caroline Islands (Heezen, MacGregor, et al., 1973; Heezen et al., 1973) or from erosion of thick 
Late Cretaceous to Eocene pelagic caps atop the surrounding Magellan Seamounts (Moberly, Schlanger, et al., 1986). Seismic profiles across the Central EMB, including those from our investigation, revealed stratigraphic relationships consistent with turbidite deposition (Shipley et al., 1983) and indicate that some reflections within the uppermost 250 - $300 \mathrm{~m}$ penetrated at DSDP Sites 199 and 585 (Fig. 6, 8.0-8.4 s TWT) extend across the entire basin (Whitman et al., 1986; this study). Although shallow turbidites were expected in the EMB, the recovery of redeposited, coal-black tuff with minimal calcareous components and the subsequent thickness $(-220 \mathrm{~m})$ of turbidites dominated by tuff was one of Leg 129's surprises.

Results from Site 802 indicate that the youngest volcanic event affecting the sedimentary history of the EMB was the formation of the Caroline Ridge and associated islands, guyots, and reefs (Shipboard Scientific Party, 1990c). Basalts collected from the Caroline Islands (Federated States of Micronesia) show a mean age progression from Kosrae (1.4 +/- 0.2 Ma) to Truk (10.9 +/- 5.0 Ma, i.e. Miocene) (Keating et al., 1984). They display a linear trend that is co-polar with the Hawaiian chain from 0 to $14 \mathrm{Ma}$ and have been inferred to mark the track of the Pacific Plate across a hotspot now located eastsoutheast of Kosrae (Jarrard and Clague, 1977; Keating et al., 1984). It is difficult to separate the bathymetric expressions of the Caroline Ridge and the Ontong-Java Plateau located just south of the Caroline Islands and it is likely that the Caroline Islands were simply emplaced at the edge of this already anomalously shallow mid-Cretaceous oceanic plateau. 
Our seismic stratigraphic observations are consistent with a Caroline Island source location for the tuff recovered at Site 802 and a Magellan Seamount source for the Upper Cretaceous - Holocene carbonate turbidites at Sites 199 and 585. The key seismic observations are illustrated in Figures 9 and 5B and show the high-amplitude, semicontinuous reflections correlated to the Miocene tuff/pelagic clay/calcareous material at Site 802 (Fig. 4C) appear to thicken toward the Caroline Ridge and downlap toward the basin reaching a nearly constant thickness of $\sim 150-200 \mathrm{~m}$. The well-indurated tuff penetrated at Site 802, however, does not extend to the margins of the EMB as it is not present at DSDP Sites $59,61,199,585$, or 452 . Our seismic observations indicate the Miocene tuff is derived from sources to the south (Caroline Islands) and appears to extend towards the Ogasawara Fracture Zone and Magellan Seamounts approximately $\sim 250 \mathrm{~km}$ east of Site 802 along one of our seismic profiles. The inferred eastward extent of Miocene tuff in the EMB corresponds to a regional bathymetric high, a subtle shallowing of Horizon $\mathrm{B}$, the thinnest $(-200 \mathrm{~m})$ sedimentary section, and a change from highly reflective (opaque) to a more transparent seismic facies (Fig. 5B). To the east, the Tertiary calcareous turbidites recovered along the eastern margin of the EMB at DSDP Sites 199 and 585 appear to dominate over the tuffaceous component. These turbidites onlap the seamounts to the east (Fig. 6), north and south of DSDP Site 585 (i.e., Ita Mai Tai) (Shipley et al., 1983; Moberly, Schlanger, et al., 1986; this study).

In short, the relatively thick $(100-300 \mathrm{~m})$ Tertiary section in the EMB changes from volcanogenic turbidites in the south-central to dominantly calcareous turbidites along 
the eastern margin. To the west and north the Tertiary section becomes pelagic, thins, and is dominated by radiolarian clay. Our seismic profiles, however, do not constrain the location of this transition. A thin Tertiary section that is represented entirely by pelagic clay with varying amounts of volcanic-arc ash is common throughout the western Pacific east of the trench system. In this region DSDP reports all identify hiatuses of varying duration after the Late Cretaceous, most commonly Late Cretaceous cherts overlain unconformably by a thin layer of Miocene or younger pelagic clays. The central EMB is actually quite unusual in this respect because of the relatively large accumulation of Tertiary turbidites. In addition, the inferred distances traversed $(-300-400 \mathrm{~km})$, the thickness of massive beds (on a meter scale), the unusual mineralogy, and the almost "welded" nature of portions of the Miocene volcaniclastic gravity flows are remarkable (Lancelot, Larson, et al., 1990; Karpoff et. al; Lees et al.; Salimulah, all this volume).

Lees et al. (this volume) report the highly vesicular glass and clasts of alkalinebasaltic nature suggests of late-stage construction of an oceanic island and that shallowwater phreatomagmatic processes could have created hyaloclastic material recovered at Site 802. There is abundant evidence that hyaloclastic material, such as the tuff recovered in the EMB, can be produced above and below the sea surface by volcanism in a variety of tectonic environments (e.g., not only explosive island arcs) and can be transported great distances. The growth of submarine volcanoes from abyssal depths through the critical depth (pressure) for the onset of explosive volcanism and/or hydromagmatic processes leads to the production of hyaloclastic material. For example, Batiza et al. (1984) provide 
convincing evidence for lava fountaining even at depths $>3000 \mathrm{~m}$ which created abundant hyaloclastite deposits on young seamounts near the East Pacific Rise and ash-size glass shards are presently being produced at active submarine volcanoes such as "Kick em Jenny" (Sigurdsson et al., 1980). Hyaloclastite grain-flow deposits recovered during DSDP Leg 47, interpreted to have formed subaqueously during the initial growth of one of the Canary Islands, have been redeposited at least $100 \mathrm{~km}$ into the surrounding basin (Schmincke and von Rad, 1979). Subaerial pyroclastic flows entering the sea from eruptions in the Lesser Antilles initiated subaqueous pyroclastic debris flows (including charred wood) which were deposited (up to $5 \mathrm{~m}$ thick) in the Grenada Basin more than $250 \mathrm{~km}$ from the known island source (Carey and Sigurdsson, 1980).

The steep slopes (40-9o over $\sim 50 \mathrm{~km}$ ) of the Caroline islands/seamounts/atolls allows for the acceleration and long transport distances across the more regional gentle gradient $(0.20)$ from the Caroline Ridge ( $5000 \mathrm{mbsl})$ to the EMB at $5800-6100 \mathrm{mbsl}$. Small amounts of late Miocene-Pliocene volcanic ash noted at DSDP Site 462 in the Nauru Basin (Fig. 1) were interpreted to relate to the formation of the easternmost Caroline Island of Kosrae (Larson, Schlanger, et al., 1981). The lack of thick tuff deposit at Site 462 in the Nauru Basin $300 \mathrm{~km}$ east of the youngest Caroline Island, Kosrae, and the greater number and size of seamounts/atolls bordering the EMB to the south, indicate that volcanic activity of the Caroline Hotspot was much more robust in the Miocene than at present. The large east-west component of plate motion $(\sim 100 \mathrm{~km} / \mathrm{m} . \mathrm{y}$.) indicates that DSDP Site 462 was more than $1000 \mathrm{~km}$ east-southeast of the hotspot during the Miocene 
while Site 802 would have remained within $300-400 \mathrm{~km}$ north of the more intense Miocene volcanic activity which was presumably creating Truk and surrounding atolls.

\section{Cretaceous Turbidites in the East Mariana Basin}

Reflections of the Lower Transparent Unit in the EMB terminate against or onlap the Aptian basalt surface as it rises out of the EMB toward the Caroline Ridge (Figs. 5B and 9), indicating that the Coniacian - late Campanian turbidites penetrated at Site 802 do not originate from sources to the south (e.g, the flanks of the Ontong-Java Plateau). The Aptian flow/sill surface and overlying Late Cretaceous turbidites appear to onlap or thin onto Ita Mai Tai Ridge, and basalt dredged from Ita Mai Tai Guyot (Figs. 2 and 7) has been radiometrically dated at $120+/ 1.0 \mathrm{Ma}$ (M. Pringle, pers. comm., 1991). In addition, the Late Cretaceous volcanic turbidites (Unit V, Site 802) do not have a correlative volcanic deposit at DSDP Site 585 where older, Aptian -Albian volcanic debris were recovered (Figs. 4C and 6) (Moberly, Schlanger, et al., 1986; Shipboard Scientific Party, 1990c). These relationships indicate that the source(s) for the Late Cretaceous volcanic deposits recovered in the central EMB must be to the west of Site 802 or from a seamount(s) in the Magellan Group younger than those immediately surrounding DSDP Site 585 (e.g., Ita Mai Tai). DSDP Site 61 lies $\sim 625 \mathrm{~km}$ west of Site 802 proximal to a seamount province just seaward of the Mariana Trench. Here, Santonian-age radiolarian clay lies in depositional contact/ interbedded with basalt flows. These flows lie $\sim .03 \mathrm{~s}$ above a regional basement reflection (Shipboard Scientific Party, 1971) and are interpreted to relate to the growth of surrounding seamounts, implying that these seamounts may have 
acted as a source for Late Cretaceous volcanic material. The northwest-southeast linear trend of the Magellan Seamounts is, we think, structurally controlled by the Ogasawara Fracture Zone and does not represent a systematic time progressive trace of a hotspot (see following sections). While Ita Mai Tai Guyot is Aptian in age, basalt dredged from the seamount labeled "86 Ma" in Figure 7 has been radiometrically dated (40/39 Ar) at $86+/-$ 1.0 Ma (M. Pringle, pers. comm., 1991), indicating that this Magellan seamount was created, or was at least volcanically active, during the Santonian. It seems possible, then, that the seamount(s) of the Magellan group and those bordering the EMB to the west provided the central EMB with episodic, distal volcanic/biogenic turbidites of Late Cretaceous age. However, if some of the Magellan group are the source for volcanic/biogenic debris younger than Albian why are there virtually no volcanic turbidites of this age recovered at Site 801 in the PB? One explanation lies in the structural control of sediment distribution imposed by the Ogasawara Fracture Zone and Magellan Seamounts which separate the PB and EMB.

\section{Compara Fracture Zone and Flexural Moat}

Magnetic anomalies M22-M36 are offset approximately $500 \mathrm{~km}$ left-laterally from the EMB to the $\mathrm{PB}$ and are separated by a region approximately $300 \mathrm{~km}$ wide. The fracture zone(s) that offset these lineations is an original feature of the Jurassic Pacific Plate and is inferred to lie somewhere within this broad zone; however, its primary morphotectonic expression is not clearly defined bathymetrically. Seamounts of the Magellan group are scattered within this region and appear to be aligned approximately 
perpendicular to magnetic lineations and thus lie along the trend inferred for a fracture zone offset. Intra-plate volcanism in the form of volcanoes and elongate ridges that are localized along and within fracture zones is well documented and has been used as an argument for a weakened lithosphere along fracture zones (Vogt, 1974; Batiza, 1981; Lowrie et al., 1986). The apparent alignment of the southern Magellan Seamounts along this fracture zone, in addition to age constraints from dredge samples and cored redeposited volcanogenic material indicate that it may have become one of many focal points for mid-plate volcanism beginning in the Aptian and extending into the Santonian.

Sediment-unloaded Horizon B (following Crough, 1983; Renkin and Sclater, 1988), derived from our MCS profiles, plunges approximately $600 \mathrm{~m}$ over $32 \mathrm{~km}$ as this inferred fracture zone is approached along an FM35-12 track from the EMB across DSDP Site 585 toward the PB (see Fig. 3 for location; Fig. 6). The deepening of Horizon B over distances of $20-40 \mathrm{~km}(\sim 19 \mathrm{~m} / \mathrm{km})$ is comparable to that observed for oceanic crust proximal to large offset fracture zones in the North Pacific (e.g., Mendacino) as well as along the present day East Pacific Rise axis as transform discontinuities are approached. Correlations of seismic stratigraphy with drilling results from DSDP Site 585 indicate that the total depth reached at this site corresponds to a zone of relatively high-amplitude conformable reflections at approximately 8.9 to 9.0 s TWT (Moberly,Schlanger, et al., 1986; this study) and may correlate with the well-cemented, Aptian-age volcaniclastic turbidites and debris flows lying $260 \mathrm{~m}$ above the high-velocity basement at $1150 \mathrm{mbsf}$ (9.2 s TWT) as determined by sonobuoy 20 (Abrams et al., in press) (Figs. 5C and 6). 
The anomalous depth to volcanic basement at Site 585 of $\sim 7250 \mathrm{mbsl}$, compared to the depth of Horizon B (6100 - $6500 \mathrm{mbsl})$ in the majority of the EMB and PB, marks this area as the trough of the Ogasawara Fracture Zone. The simplified interpretation of stratigraphy in this region (Fig. 6) indicates that reflections correlated with Aptian-Albian debris flow/turbidites do not extend beyond the immediate vicinity of DSDP Site 585 and that only reflectors correlated to latest Cretaceous and younger calcareous turbidites extend into the EMB. It appears that the pre-existing fracture zone trough trapped the majority of the large-scale, initial mass-wasting deposits of Aptian-Albian age close to the volcanic source.

Further to the north along the MESOPAC II seismic profile from the PB toward the EMB, Horizon B appears to deepen over a much broader zone, approximately $640 \mathrm{~m}$ over $120 \mathrm{~km}$ (Figs. 5B and 10). This profile has a decidedly flexural shape that can be modeled by a broken elastic plate with an effective elastic thickness $\left(T_{e}\right)$ of $28.5 \mathrm{~km}$ which is loaded at a free end (Abrams, unpubl. data). The axis of the Ogasawara Fracture Zone lies to the west of this profile (see Fig. 3 for location; Figs. 5B and 10). Our single seismic profile of this area (Fig. 10) is strikingly similar to MCS and SCS profiles across the Hawaiian flexural moat (ten Brink and Watts, 1985; Rees et al., in press) which reveal a thick wedge of well-stratified material with reflectors dipping and diverging toward the island/seamount source and onlapping the rising volcanic basement reflection (e.g., Horizon B). The reflection geometry of the Hawaiian moat has been interpreted as a series of stacked debris flows that thicken toward the source and overlie pre-moat pelagic 
sediments of constant thickness (Rees et al., in press).

Similarly, we have interpreted the relatively transparent intervals bounded by highly reflective continuous horizons displayed in Figure 10 as a sequence of episodic debris flows bounded by well-bedded turbidites. The lowermost interval overlying Horizon B appears to maintain a fairly uniform thickness with slight thinning toward the PB (e.g., away from the seamount load). This interval was deposited when Horizon B was nearly flat or soon after emplacement of the load; thus this sequence could represent Jurassic-age pelagic sediments or poorly bedded Aptian - Albian debris from the seamount load (as at Site 585). The overlying reflections that make up the majority of the section are unquestionably onlapping/thinning toward the $\mathrm{PB}$ and represent redeposited volcanic/carbonate material filling in the flexural moat and spilling out onto the PB. The uppermost units which we interpret as Late Cretaceous (i.e., younger than Albian) turbidites-debris flows clearly pinch out over $\sim 100 \mathrm{~km}$, while it appears that the lowermost units continue to overlie Horizon B into the PB over ranges greater than 100 km. Our preferred interpretation of Horizon B in this area of the PB is that it represents sills/flows no older than Aptian (<124 Ma) (Abrams et al., in press) and that the immediately overlying units are Aptian - Albian volcanogenic debris flows/turbidites. Overlying turbidite units represent an ever-decreasing sediment supply, and an increasing calcareous component with possible input from renewed volcanism of approximately Santonian age. These Late Cretaceous turbidites are effectively trapped within what appears to be a flexural moat. Thus on the PB side of the Ogasawara Fracture 
Zone/flexural moat, Aptian-Albian turbidites extend into the PB while younger alcareous/volcanic turbidites do not. In the EMB just the opposite occurs, as Aptian/Albian turbidites are largely confined by the deep trough of the fracture zone. These conclusions are based only on the limited (just two profiles) seismic observations but are consistent with the drilling results in the PB (i.e. Site 801) and EMB. It is likely that volcanogenic turbidites of Aptian-Albian age extend into the EMB at other localities, perhaps along the northern margin. For example, drilling results of DSDP Site 452 document Late Cretaceous chert at $\sim 25$ mbsf and reprocessed (1976 vintage) MCS and sonobuoy data indicates that volcanic basement (i.e., Horizon B) lies at $\sim 500$ mbsf and is overlain by a seismic section most similar to Site 800 (Abrams, unpubl. data). More than the similarities in seismic facies, the $\sim 500 \mathrm{~m}$ thickness between Campanian age chert and basement implies significant redeposition of presumably Aptian and younger age.

Thtions between Sites 800 and 801 in the Pigafetta Basin

It is possible to confidently trace reflectors corresponding only to Horizon $\mathrm{B}$, to the top of Late Cretaceous chert/porcellanite/clay, and to seafloor over the $\sim 550-\mathrm{km}$ distance separating Sites 800 and 801 (Fig. 5A). There is, however, another, more localized and distinctive reflection horizon labeled "pre-Aptian unconformity" (Figs. 4B and 5A) that marks the sudden change from clayey radiolarites below $\sim 318$ mbsf to volcaniclastic turbidites above at Site 801 (Shipboard Scientific Party, 1990b; Ogg et al., this volume). The interval between Horizon B and the "pre-Aptian unconformity" essentially represents the Late Jurassic - Early Cretaceous pelagic sediment present in the PB. Unfortunately, it 
has proven difficult to confidently identify this reflection between Sites 801 and 800 . To the southwest of Site 801, this reflection is discontinuous and appears to truncate against or merge with Horizon B at the "Rough-Smooth Boundary", implying that southeast of this boundary all pre-Aptian material lies buried beneath sills/flows no older than Aptian (Figs. 5A and 7). The reflection corresponding to the Early Cretaceous unconformity also appears intermittently along a watergun profile for $-200 \mathrm{~km}$ northwest of Site 801 (Fig. 5A). Beyond this point this reflection can no longer be uniquely identified by its position between two relatively transparent seismic units. Thus, we are only able to map thickness variations of Late Jurassic-Early Cretaceous pelagic sediments between Site 800 ( $50 \mathrm{~m}$ thick) and Site 801 ( $140 \mathrm{~m}$ thick) over a portion of the $\sim 550 \mathrm{~km}$ distance between these sites. We cannot, however, identify any seismic stratigraphic relationships that suggest that this pelagic interval (or portion of) is missing or buried between Sites 800 and 801 other than in the restricted areas where Horizon B has been interpreted as Aptian sills/flows rather than the top of Jurassic oceanic crust (Fig. 7) (Abrams et al., in press).

Site 801 is located on the distal south-southwest flank of a broad regional high protruding into the PB which defines the Marcus-Wake Seamount region (Figs. 2, 5A, 7). Winterer et al. (in press) report radiometric dates ranging from 82 to $102 \mathrm{Ma}$ (i.e., Campanian - Albian) from four seamounts of the Marcus-Wake Group to the northeast of Site 801 (Figs. 2 and 7); these dates bound the age range of volcaniclastic turbidites at Site 801. Data analyses presented in Lees et al. (this volume) indicate a shallow-water offridge seamount source for all volcaniclastic turbidites recovered during Leg 129 and the 
above relationships favor a seamount source location east-northeast of Site 801. Such broad regional uplift east-northeast of Site 801 may also contribute to the apparent dip of pre-Aptian strata to the west-southwest reported by Ogg et al. (this volume). In contrast, Site 800 is surrounded by much larger and more proximal individual seamounts (Figs. 2 and 7) specifically Himu (120 Ma $\sim 80 \mathrm{~km}$ ) and Golden Dragon (95 Ma $110 \mathrm{~km}$ ). The sills penetrated at Site 800 show distinct isotopic affinities to dredged basalts of both Himu and Golden Dragon seamounts (i.e., high radiogenic lead, Castillo et al., this volume Smith et al.,. 1989). This result coupled with the proximity to Site 800 make Himu and Golden Dragon seamounts the most likely source for both deep sea sills and volcaniclastic debris flows/turbidites recovered at Site 800 (Lancelot, Larson, et al., 1990;

Castillo et al.; Lees et al., both this volume).

Pate Motion and Seismic Stratigraphy

The earliest DSDP forays into the northwest Pacific found that the Upper Opaque seismic facies corresponded to massive chert accumulation underlying a relatively thin layer of pelagic clay. The diachronous nature of this shallow "first" chert was recognized by these early investigations (Fisher, Heezen, et al., 1971; Heezen, MacGregor, et al., 1973). Heezen et al. (1973) argued that the time-transgressive nature of the shallowest (youngest) chert probably marked the passage of different sites at varying times beneath the equatorial zone of high biogenic productivity. Subsequent investigations revealed that the youngest chert is not typically associated with equatorial carbonate in the older, deeper portions of the Pacific and that the correlation of "first" chert with the Upper Opaque Unit 
can be used to infer plate motion from seismic stratigraphy (Lancelot and Larson, 1975).

Aspects of the geophysical and sedimentary record which reflect the paleolatitude of sites in the PB and EMB are discussed in detail by Larson et al.; Larson and Sager; Karpoff; Ogg et al., Erba, and Steiner and Wallick.(all this volume). It seems clear from these studies that the periods of largest biosiliceous sedimentation correlate to subequatorial paleolatitudes during the Cenomanian-Campanian at both Sites 800 and 801 in the PB and somewhat latter in the EMB ( Campanian-Eocene). The subsequent diagenesis of primary biogenic silica (Behl and Smith, this volume) creates chertporcellanite. The large impedance contrast between a thin layer $(0-100 \mathrm{~m})$ of pelagic clay and the shallow chert/porcellanite/clay creates the distinctive high-amplitude semicontinuous series of reflections which are easily followed throughout the PB and northern EMB (Fig. 5). Following DSDP Leg 20 it was believed that the Upper Opaque Unit in the EMB did not represent the top of chert/porcellanite/clay $+/$ - chalk sequence but was instead a thick sequence of carbonate turbidites (i.e., DSDP Site 199, Heezen, MacGregor, et al., 1973). Basinwide seismic profiles have shown that the reflection geometry is indeed consistent with a basin-filling turbidite sequence, which was further confirmed at Site 802 , where the story is complicated by volcanogenic turbidites from the Caroline Hotspot (Shipley et al., 1983; this study). Thus, the identification of a seismic unit representing a paleoequatorial crossing may be obscured in the EMB. Whitman et al. (1986) first noted that the increase in chert/chalk silicified limestone of mid-Eocene - late Campanian defining unit II at DSDP Site 585 was correlated to a distinct high-amplitude 
reflection (-8.4 s TWT) which continued out into the EMB. Our seismic profiles reveal that this horizon appears as a series of semicontinuous reflections (waterguns) and/or a single, higher amplitude event (airguns) that can be traced between DSDP Site 585 - Site 802 and throughout the EMB. At Site 802 late Paleocene-early Eocene quartz chert is first recovered below 292 mbsf within redeposited nannofossil chalk (Shipboard Scientific Party, 1990c; Behl and Smith, this volume) and is correlated to the reflections at 8.2-8.3 s TWT (Fig. 4C) which, in turn, can be traced to reflections at $\sim 8.4 \mathrm{~s}$ TWT at DSDP Site 585 (Fig. 6) and $~-8.3$ s TWT at DSDP Site 199. Increased chert abundance, representing an equatorial crossing, is consistent with paleolatitudes derived for Site 802 (Larson et al., this volume). However, it is also clear that in sediments younger than Eocene, diagenetic chert is rarely found even with an abundant biosiliceous source (Lancelot and Larson, 1975; Behl and Smith, this volume), and so it appears that this reflection(s) may also define pre-to post-Eocene material in the EMB.

The basinwide continuity of the first chert reflection indicates that redeposition events had become less frequent by this time, and is quite useful for defining basinwide trends in sedimentation. The highest amplitude reflections of the chert/chalk/clay (Units III and IV) and weaker events below appear to truncate against, or onlap Horizon B rising toward the Caroline Ridge indicating that Eocene or younger sediments dominate the sedimentary section overlying volcanic basement on the Caroline Ridge (Figs. 5B and 9). To the east the first chert horizon rises in section and the overlying material changes from chalk-tuff to nannofossil-ooze/chalk/pelagic clay and the thickness of underlying 
calcareous turbidites increases (Figs. 5B and 5C). Immediately east of the Ogasawara Fracture Zone the first chert appears quite shallow, indicating a much-reduced Tertiary section that is observed throughout the majority of the PB. Only the latest equatorial crossing of the Pacific Plate can be correlated to a distinct basinwide reflection; however, there is evidence that the Pacific Plate may have crossed the equator from north to south, or at least was within $00-100 \mathrm{~S}$ latitude in the Late Jurassic (Larson et al.; Larson and Sager, Ogg et al.; Steiner and Wallick, all this volume).

\section{CONCLUSIONS}

1. A thin $(<400 \mathrm{~m})$ semicontinuous sequence of mid-Cretaceous (early Aptian) deep sea flows/sills overlie Jurassic oceanic crust and Upper Jurassic - Lower Cretaceous sediments throughout the entire EMB and southeast PB. The high-amplitude, flat-lying Horizon B reflection is created by the impedance contrast between low-velocity sediment ( $2 \mathrm{~km} / \mathrm{s}$ ) and high-velocity ( $>5 \mathrm{~km} / \mathrm{s}$ ) flows/sills. Jurassic oceanic crust and overlying Upper Jurassic - Lower Cretaceous sediments unquestionably exist at Site 801 and extend uncovered by younger massive igneous material semicontinuously between Site 801 and Site 800.

2. The Ogasawara Fracture Zone is a primary tectonic feature of the embryonic Pacific Plate. This fracture zone acted as a focal point for Aptian-age extrusive activity as indicated by the coincident alignment of seamounts. This seamount load flexurally depressed the lithosphere surrounding the fracture zone. The resulting morphotectonic 
features (seamounts, fracture zone, flexural moat) separate the PB from the EMB and influence the source and distribution of redeposited material.

3. Stratigraphic, lithologic, and age relationships, indicate that Cretaceous turbidite sequences in both basins were derived from Magellan and Marcus-Wake seamounts and seamount chains of Aptian age or younger. The seamounts and atolls of the Caroline Ridge were the source of extensive Miocene-age volcanogenic turbidites, some of which are both thick and fine-grained with sources over $300 \mathrm{~km}$ to the south of Site 802 . The carbonate caps developed on Ita Mai Tai Guyot and other edifices of the Magellan chain were the source for the redeposited shallow-water carbonate sequences recovered along the eastern margin of the EMB.

4. A distinct basinwide reflection correlated with the shallowest chert/porcellanite/clay and chert/chalk sequences in the $\mathrm{PB}$ and $\mathrm{EMB}$, respectively, is a time-transgressive horizon (-Eocene - Campanian) resulting from the passage of the Pacific Plate beneath the equatorial zone of high productivity.

\section{ACKNOWLEDGEMENT}

This work was part of a joint U.S. - French effort to investigate the western Pacific basins. We wish to thank the ships crew and scientific party of the R/V Fred Moore (RIP) cruise FM35-12 and N/O Le Suroit. Perry Crampton and fellow airgun techs worked beyond the call of duty. Steffen Saustrup, Mark Wiederspahn and Patty Ganey at the Institute for Geophysics, University of Texas provided invaluable assistance in the 
processing of FM35-12 navigation and seismic data. Roland Schlich kindly provided the use of facilities at the Institut de Physique du Globe, Strasbourg, France and Marc Schaming, Jacques Renault and Cecille Pourcellot facilitated the processing of MESOPAC II seismic data. Discussions with Bob McMaster, Bob Detrick and Nancy Grindlay; reviews by $\mathrm{J}$. Lincoln and an anonymous reviewer; and editorial comments of $\mathrm{J}$. Dearmont improved this paper. This project was funded by NSF grants OCE 86-13867 (R. Larson), OCE 86-13641 (T. Shipley) and from JOIUSSAC Ocean Drilling Fellowship (JSG-CY5-4) and a USSAC grant (20431) to the first author. 
FIGURES

122 
Figure 1. Magnetic lineations of the western Pacific compiled by R. L. Larson from Nakanishi et al. (1989), Mammerickx and Sharman (1988), Larson (1976), Tamaki and Larson (1988), Handschumacher et al. (1988), Sager et al. (1988), and Hilde et al. (1976). Magnetic isochron M17 is highlighted and encloses an area of the Northwestern Pacific inferred to contain Jurassic oceanic crust and sediments. Dots locate selected DSDP sites and all three Leg 129 Sites 800, 801, and 802. Area in box is shown in Figures 2, 3, and 7. FZ = fracture zone; $\mathrm{MG}^{\prime} \mathrm{N}=$ Magellan. 


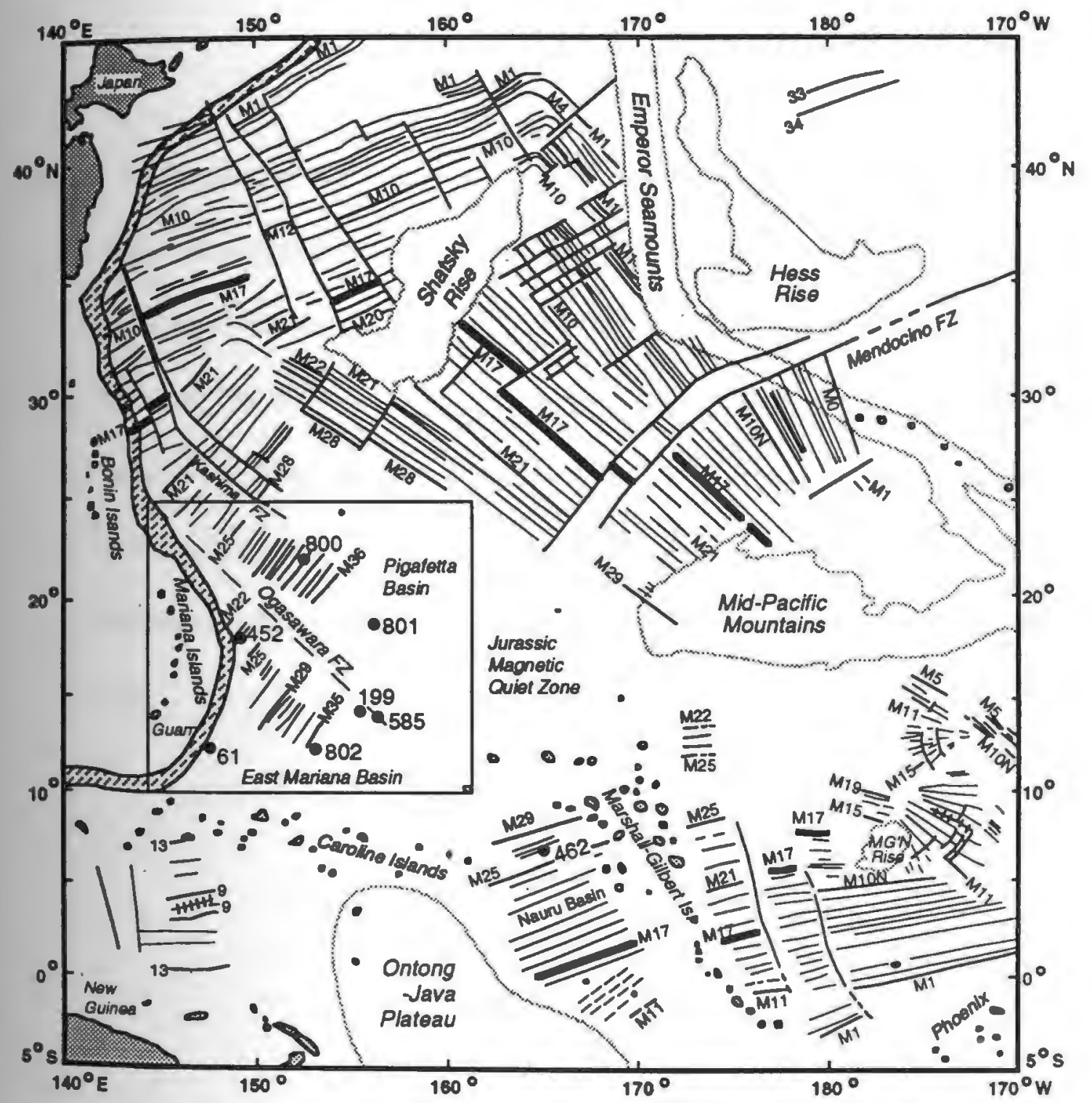


Figure 2. Bathymetry of the central western Pacific modified from Brenner and Angell (this volume) with location of selected DSDP sites and all of Leg 129 sites. Bold solid line indicates coverage of the FM35-12 and MESOPAC II regional seismic surveys. The 5500-m contour is highlighted and the $3000-\mathrm{m}$ contour is shown as a lighter line. Magnetic anomalies are modified from Handschumacher and Gettrust (1985), Tamaki et al. (1987), and Handschumacher et al. (1988). The broad zone inferred for the location of the Ogasawara Fracture Zone is bounded by the dashed line. 


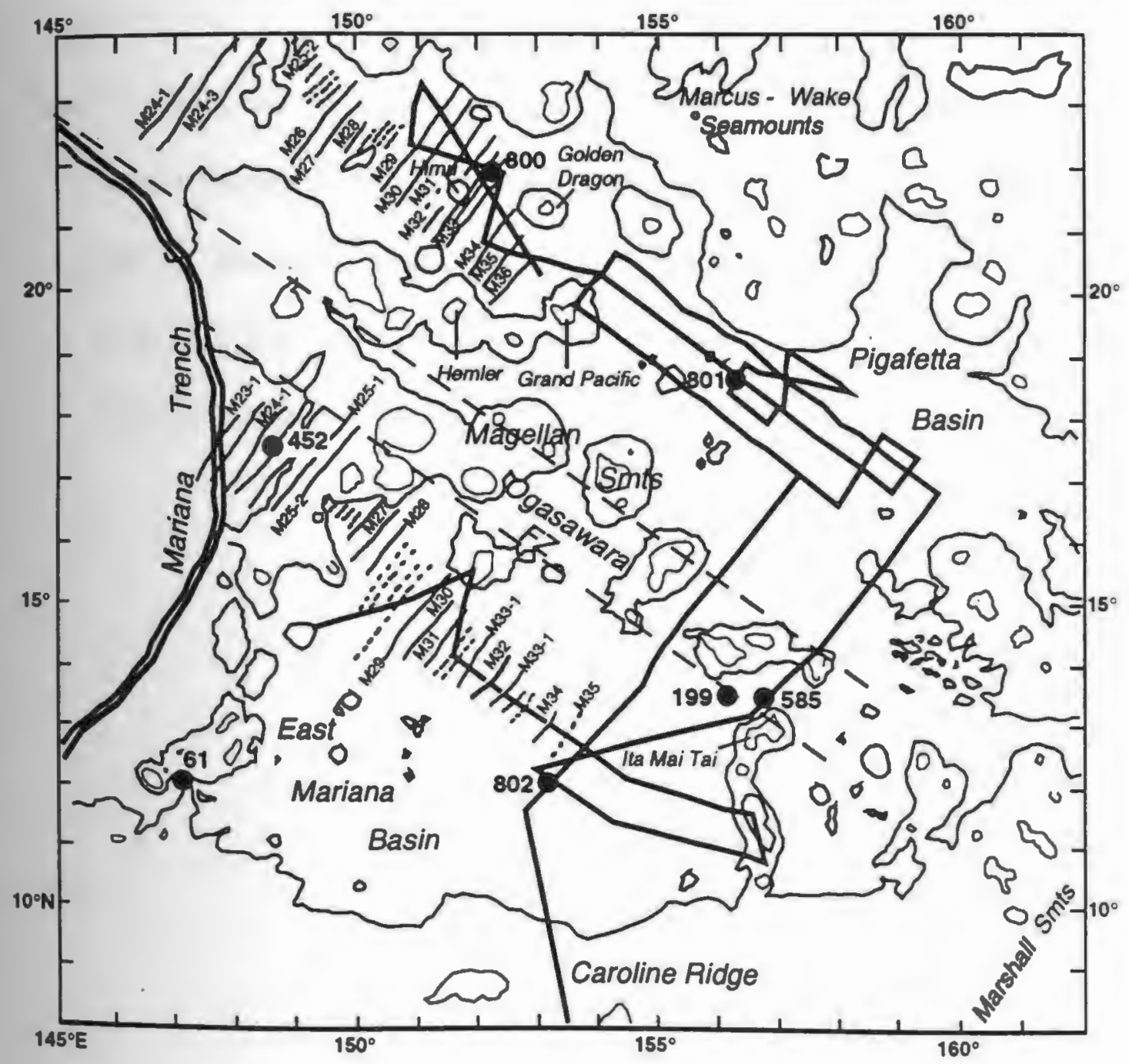


Figure 3. Solid line indicates coverage of the FM35-12 and MESOPAC II regional seismic surveys with location of Figures 4A-C, 6, 8, 9, and 10, and sonobuoy 20 (SB20). The endpoints of composite profiles shown in Figure 5 are marked A-A', B-B', and C-C' and are highlighted as shown in the legend. Dots show DSDP/ODP site locations. 


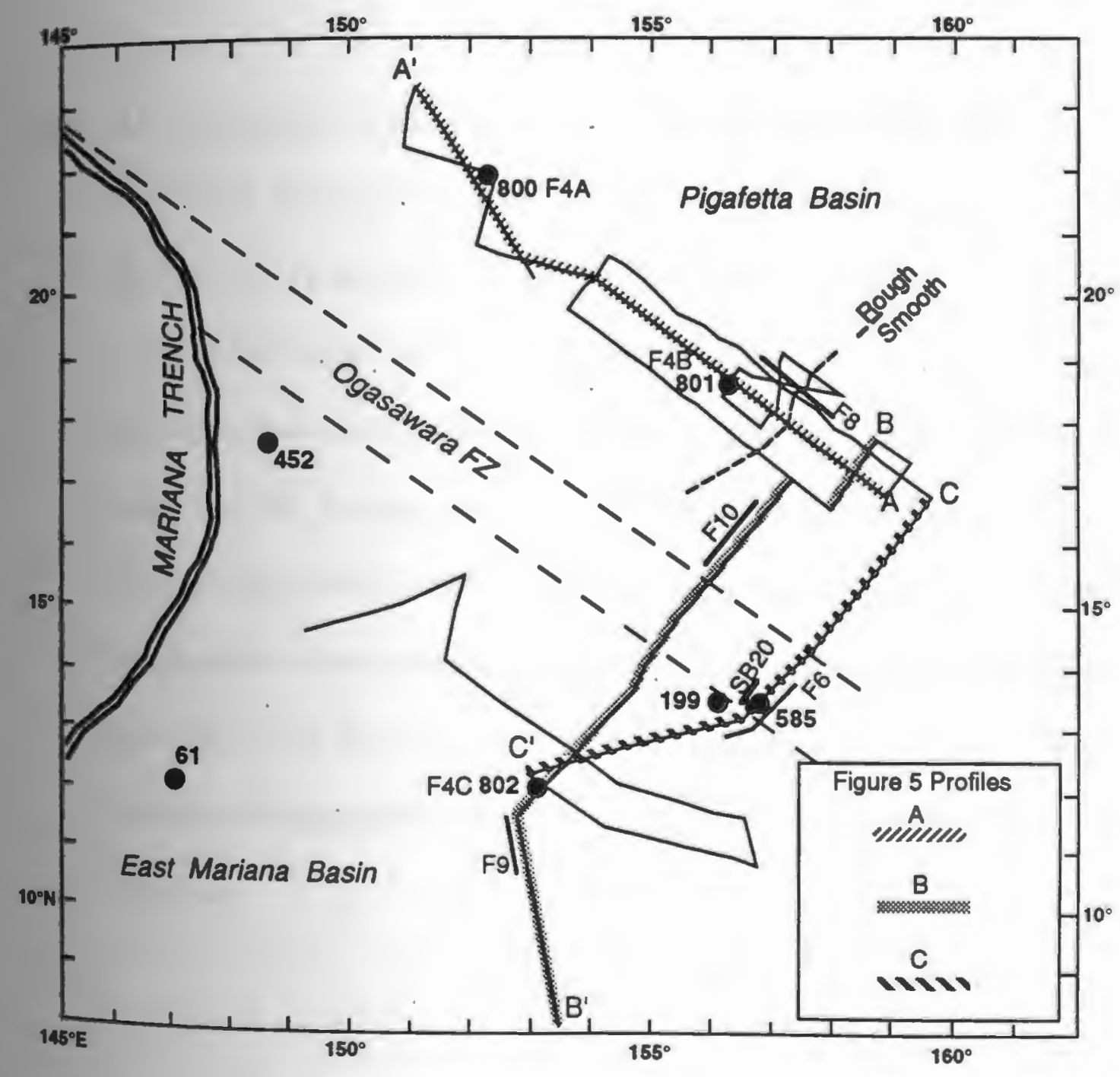


Figure 4A - C. Summary of seismic stratigraphy at Leg 129 Sites 800 (A), 801 (B), 802 (C) showing generalized correlations with lithologic units, ages and depths, with emphasis on key reflective horizons such as igneous basement and first chert (Lancelot and Larson et al.,1990). Radiometric ages are from Pringle (this volume). Site 800 imaged with SCS waterguns (two 80 in 3 ) obtained on approach to Site 800 during Leg 129; Seismic profiles shown for closest possible approach (CPA) to Sites 801 and 802 during MESOPAC II (six 80 in 3 waterguns). These near-channel records were processed and displayed with the following parameters: mute, bandpass filter 25-100 Hz, 2-trace mix, water-velocity F/K migration, $500 \mathrm{~ms}$ AGC, and vertical exaggeration $\sim 22 \mathrm{X}$ at $1.5 \mathrm{~km} / \mathrm{s} . \mathrm{O} / \mathrm{C}=$ on course, UTC $=$ Universal Time Code 

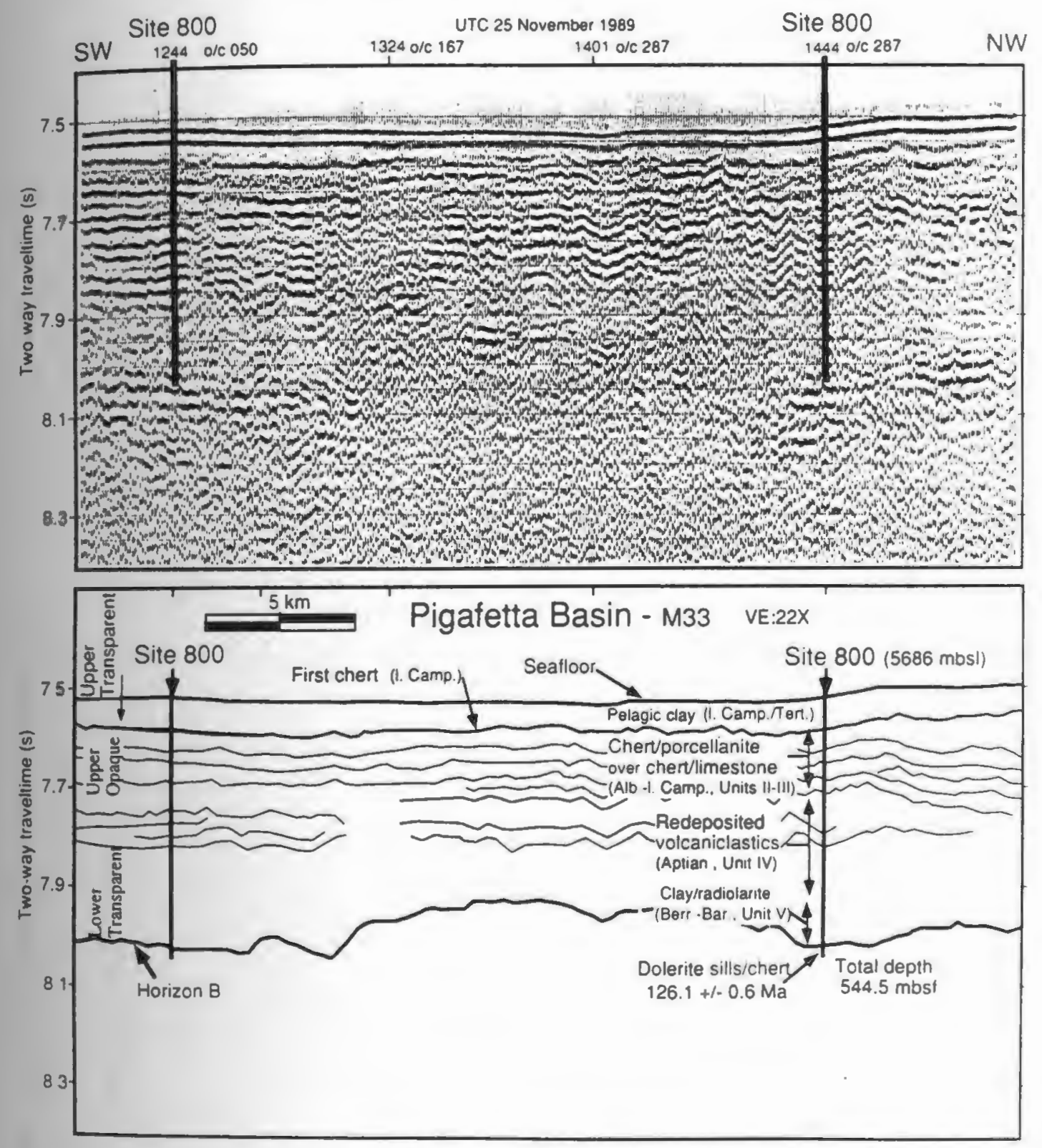

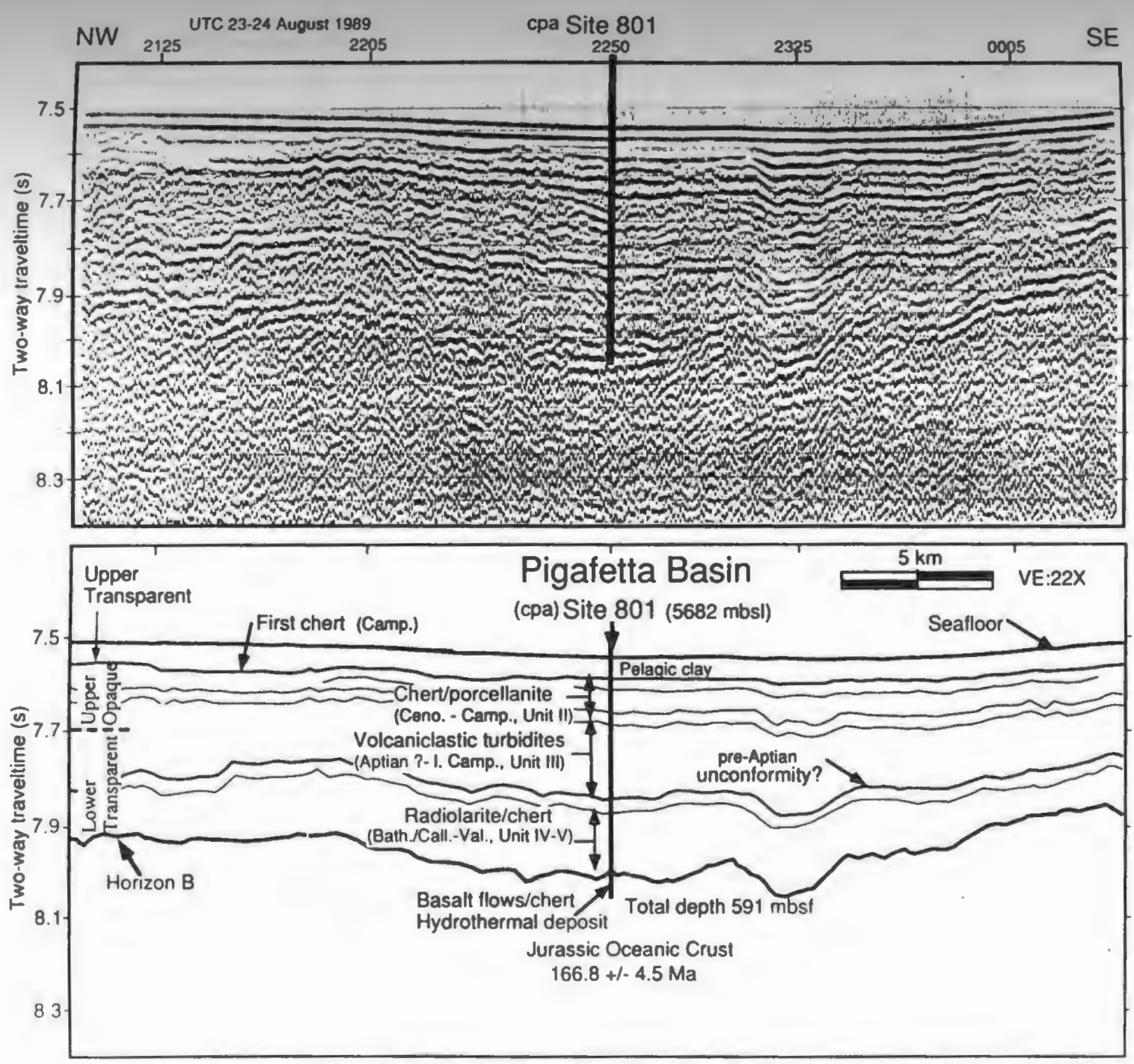

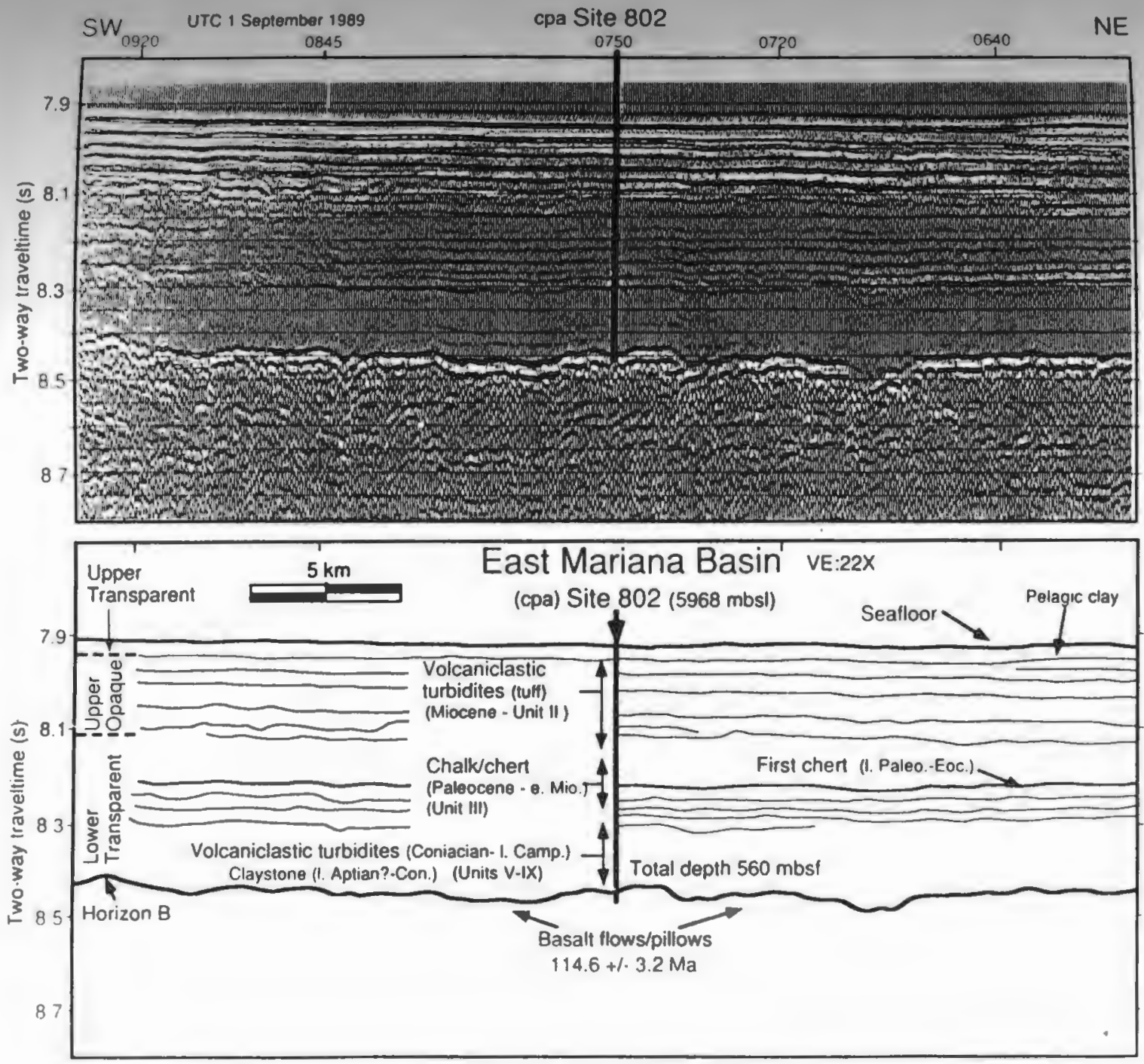
Figure $5 \mathrm{~A}-\mathrm{C}$. Three 900 to $1300-\mathrm{km}$-long profiles showing selected reflections digitized from both MCS airgun and near-channel watergun data (see Fig. 3 track chart for locations of profiles (A) A-A', (B) B-B and (C) C-C'). The deepest horizon, (Horizon B - heavy line) always represents the top of high velocity igneous material. This horizon is characterized and interpreted from direct sampling at three widely separated ODP sites, from reflection character, and from velocity structure. The middle horizon always represents the top of the first chert porcellanite and is interpreted as a time-transgressive horizon that marks the passage of the Pacific Plate beneath the equatorial zone of high productivity (Heezen et al., 1973, Lancelot and Larson, 1975). The top horizon represents the seafloor. Note the depth difference between the PB and EMB $(\sim 300 \mathrm{~m})$ and the uniformly flat Horizon $B$ (even at $\mathrm{VE}=133 \mathrm{X}$ ) in the EMB and southeast PB compared to the higher relief (at long and short wavelengths) Horizon B of the PB northwest of the rough-smooth boundary. Radiometric ages are from Pringle (this volume). TD = total depth; JQZ = Jurassic magnetic quiet zone. 

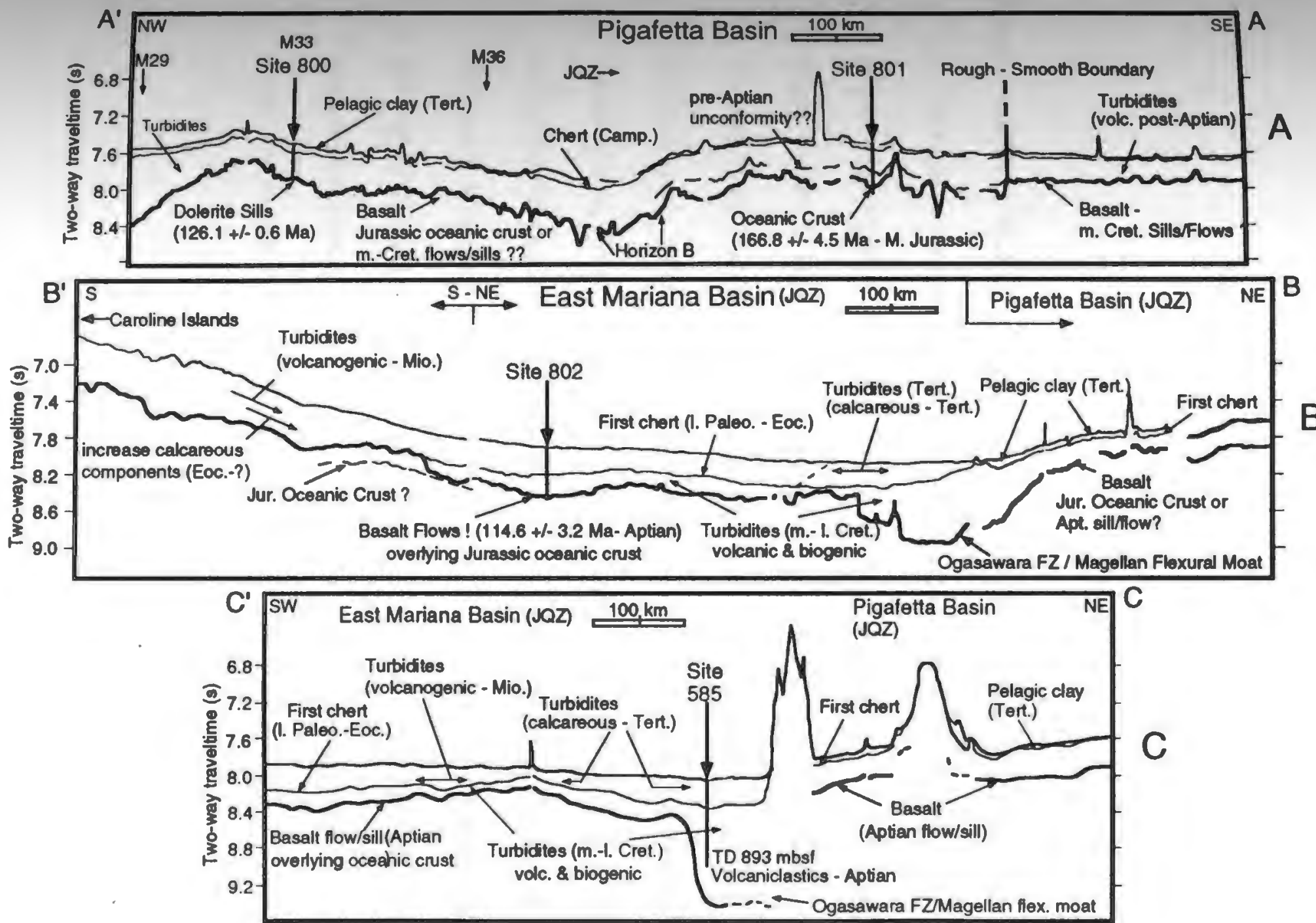
Figure 6. FM35-12 MCS airgun profile across DSDP Site 585 and the inferred location of the Ogasawara Fracture Zone. Roman numerals indicate lithologic units as presented in Moberly, Schlanger, et al. (1986). The chert/chalk horizon can be traced basinwide and is interpreted as a time-transgressive horizon marking the passage of the Pacific Plate beneath the equatorial zone of high productivity (Heezen et al., 1973; Lancelot and Larson, 1975). High-velocity Horizon B deepens over a 20 to $40 \mathrm{~km}$ range from approximately $300-600 \mathrm{mbsf}$ in the majority of the EMB to over 1150 mbsf at DSDP Site 585. Comparable deepening of the Horizon B reflector over a much larger range $(-120-160 \mathrm{~km})$ is observed along MESOPAC II line 18 shown in Figure 10. The processing and display parameters are as follows: pre-stack spike deconvolution, 120-fold stack, band-pass filter 20$60 \mathrm{~Hz}, \mathrm{~F} / \mathrm{k}$ migration, $500 \mathrm{~ms}$ AGC and vertical exaggeration of $\sim 53 \mathrm{X}$ at $1.5 \mathrm{~km} / \mathrm{s}$. 

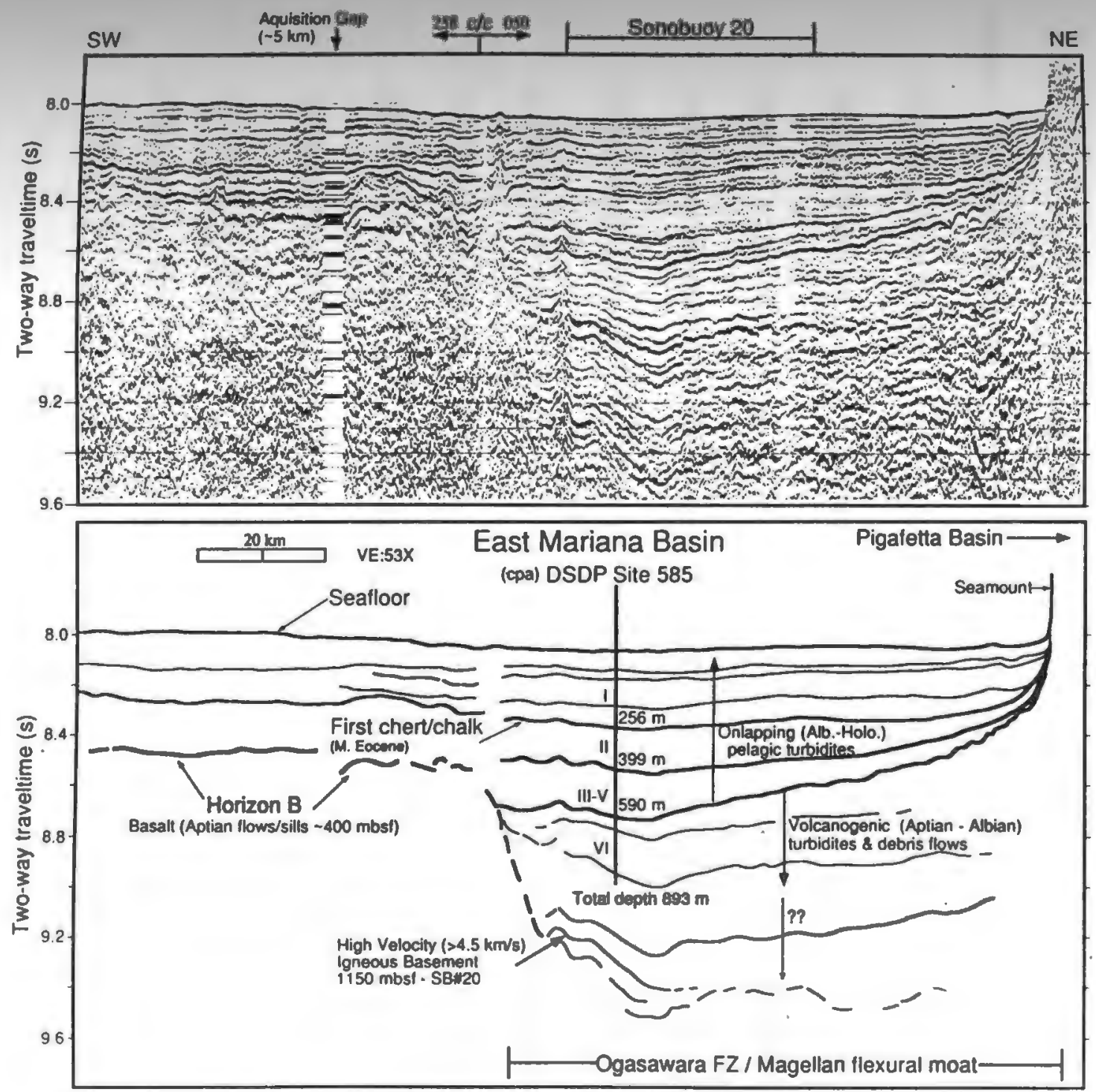
Figure 7. Simplified bathymetry (5500 $\mathrm{m}$ contour is shown) of the central western Pacific modified from Brenner and Angell (this volume). The reflection character of Horizon B and its interpretation are indicated along track from Abrams et al. (in press). The oceanic crust in the entire EMB and southeast PB $\left(\sim 500,000 \mathrm{~km}^{2}\right)$ is overlain by sills/flows of Aptian age or younger. Only a few restricted areas in the PB are confidently interpreted to contain Jurassic-age oceanic crust with no massive igneous overburden. Horizon B in extended areas (primarily in the PB) is more tentatively interpreted as Jurassic age oceanic crust with Aptian age or younger sill/flow overburden possible. Radiometric ages of basalt are given in Ma for Leg 129 Sites from Pringle (this volume), and for seamounts from Ozima et al. (1983), Keating et al. (1984), Pringle (pers. comm., 1991), Pringle (1992), and Winterer et al. (in press). Note: Grand Pacific is referred to as "D4" in Ozima et al. (1983). 


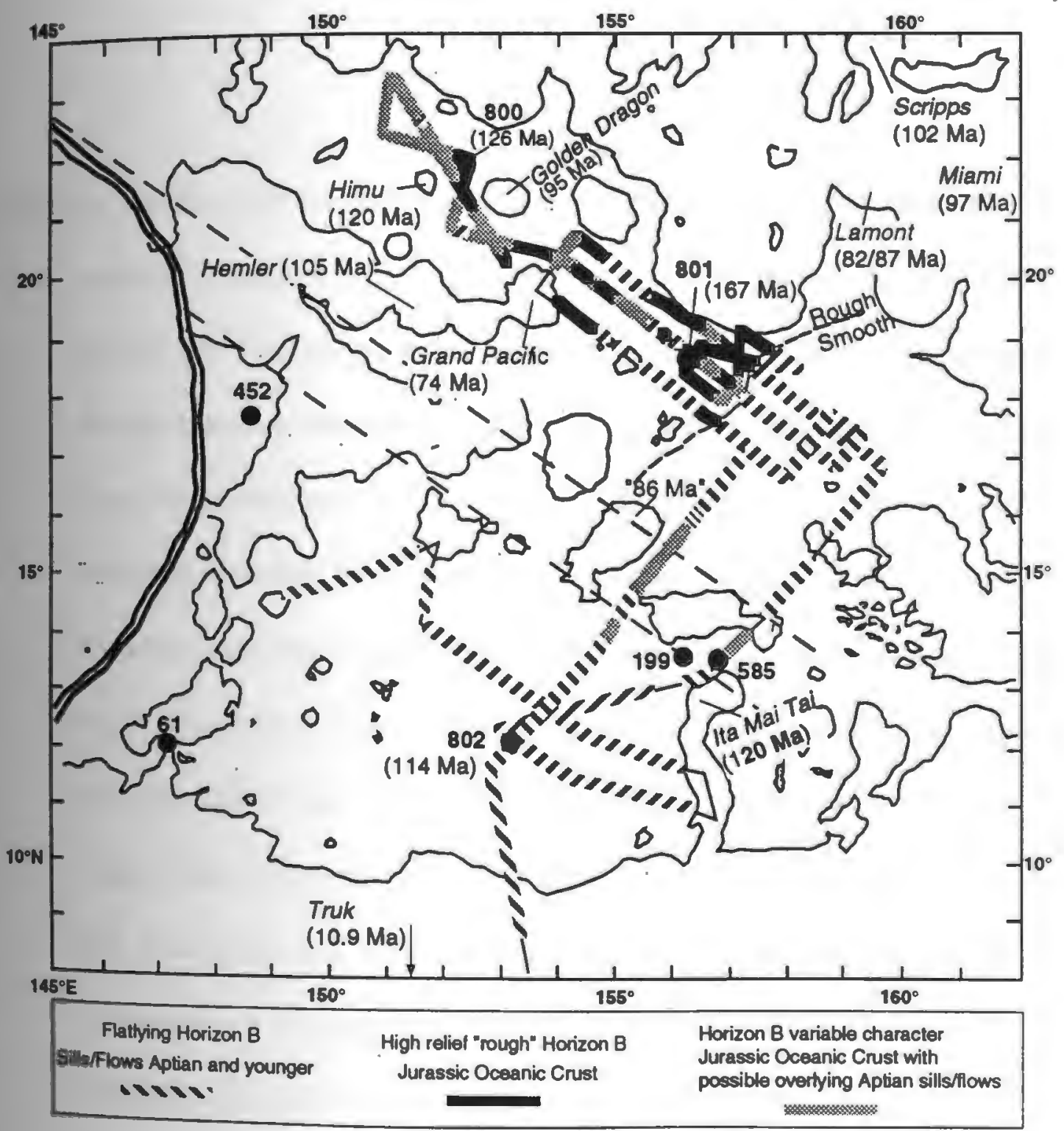


Figure 8. FM35-12 MCS airgun profile in the $\mathrm{JQZ}$ of the $\mathrm{PB}$ along an inferred flowline course and displayed at true relative amplitude. The continuous, flat-lying (at a VE of $75 x$ ), and high-amplitude Horizon B reflection southeast of the rough-smooth boundary deepens and appears to be contiguous with an undulating, diffractive, and lower reflection amplitude "rough" Horizon B. The "rough" Horizon B correlates to the top of middle Jurassic age oceanic crust (e.g., Site 801) and the "smooth" horizon is interpreted as basalt sills and flows of Aptian age overlying the unimaged top of oceanic crust. The rough/smooth boundary appears on all five of our tracks that cross this area, and a comparable boundary is not apparent in the EMB. We suggest that the boundary marks the limit of semicontinuous Aptian flows/sills. The processing and display parameters are as follows: pre-stack spike deconvolution, 120-fold stack, band-pass filter 8-25 Hz, F/K migration, and vertical exaggeration of $\sim 75 \mathrm{X}$ at $1.5 \mathrm{~km} / \mathrm{s}$. 

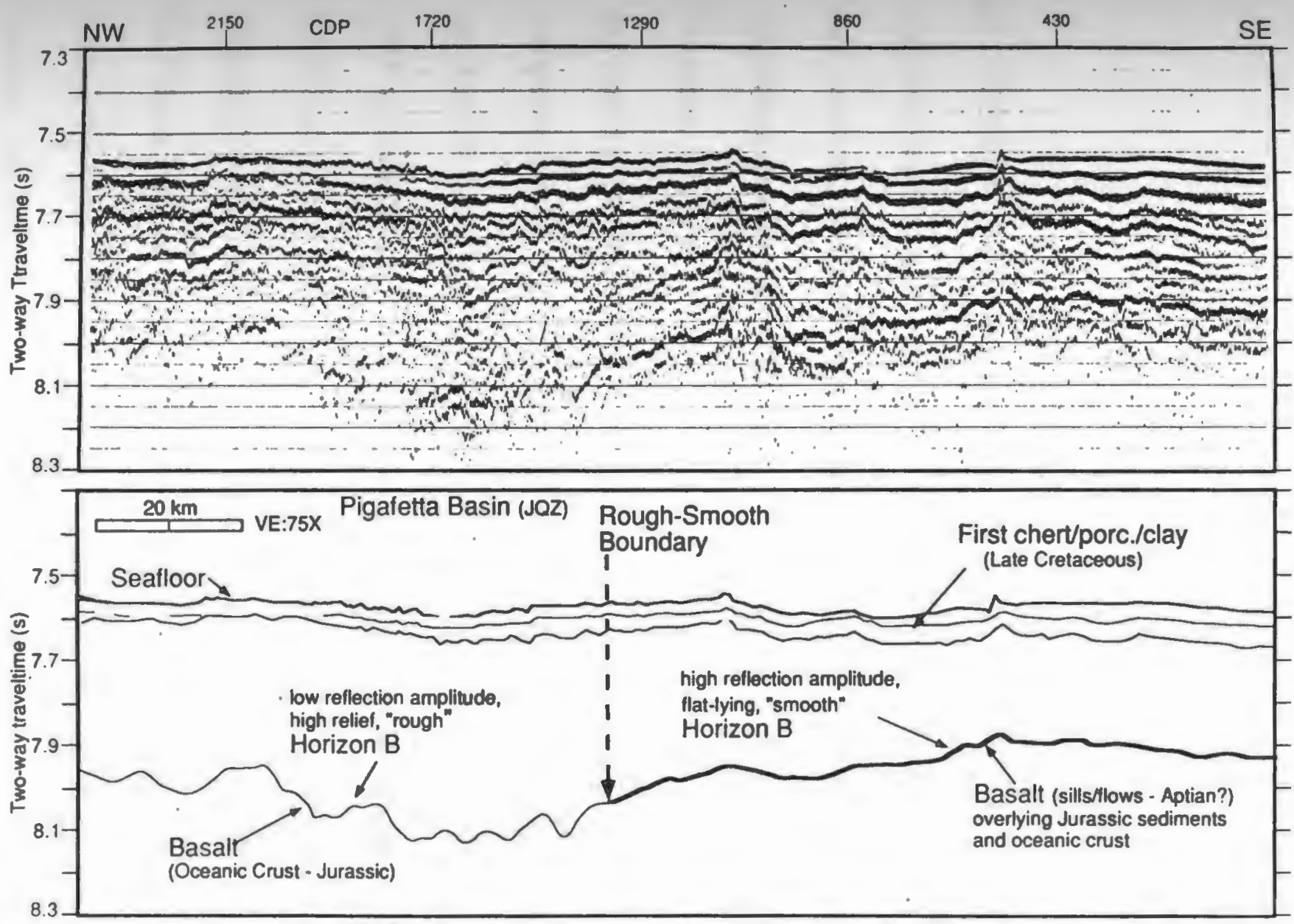
Figure 9. MESOPAC II SCS watergun profile in the southern EMB. Site 802 penetrated extrusive basalt dated at $114.6+/-3.2 \mathrm{~m}$.y. (Pringle, this volume) beneath Aptianage sediment, this horizon is onlapped by late Paleocene chert/chalks and underlying Late Cretaceous turbidites, indicating they may be derived from the Magellan Seamounts rather than the Caroline Ridge. The basalt horizon penetrated at Site 802 continues up onto the Caroline Ridge. The high-amplitude continuous reflections that are correlated to the Miocene-age volcanogenic turbidites recovered at Site 802 are observed to thicken to the south and downlap toward the EMB which indicates, along with their age, that the Caroline Islands are the most likely source. A weak semicontinuous, relatively high relief horizon imaged beneath the rising flow/sill horizon may represent the top of oceanic crust. This near-channel record is processed and displayed with the following parameters: mute, 2-trace mix, band-pass filter $25-100 \mathrm{~Hz}$, water-velocity F/K migration, 500 ms AGC, and vertical exaggeration $\sim 53 \mathrm{X}$ at $1.5 \mathrm{~km} / \mathrm{s}$. 

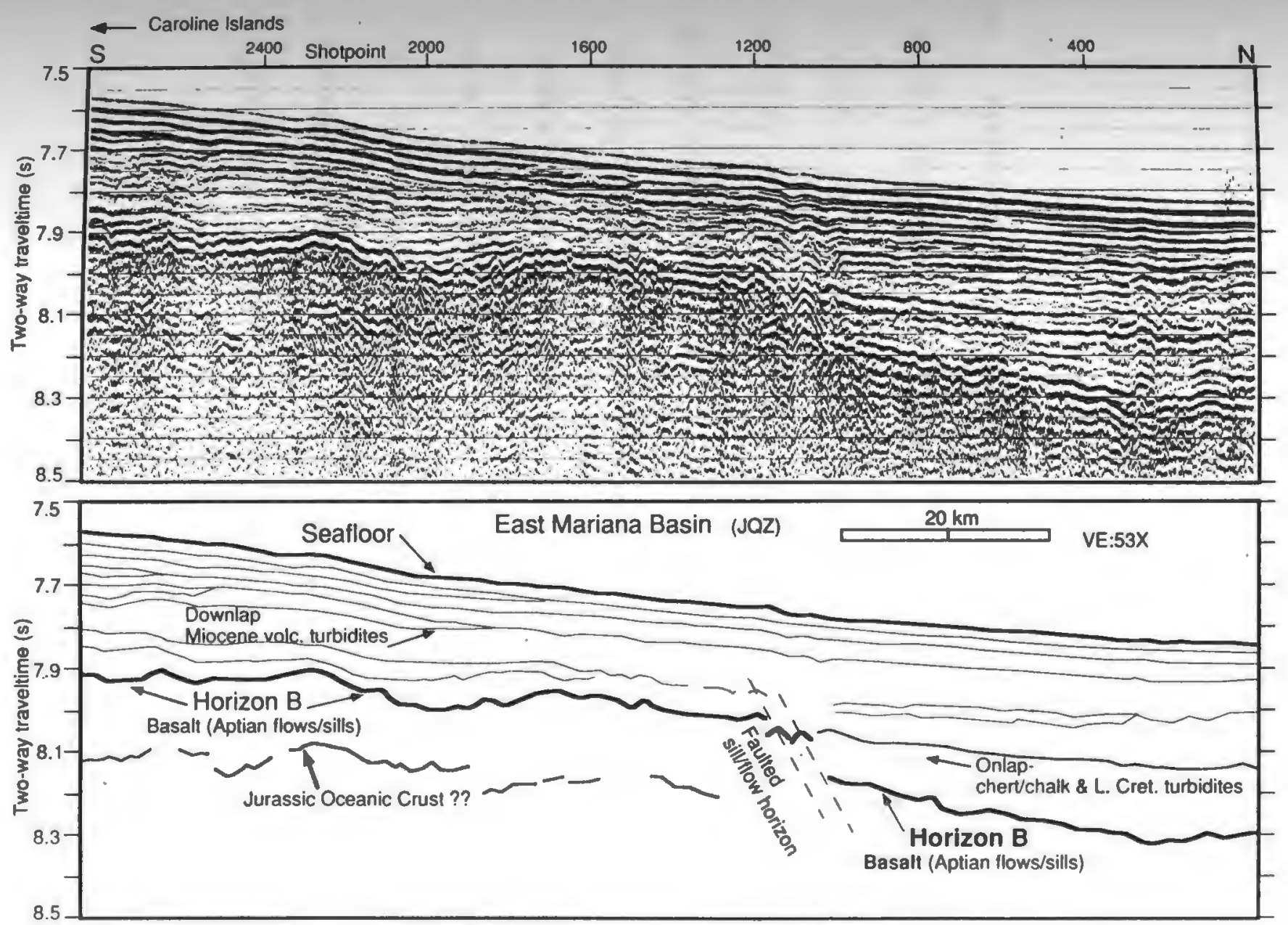
Figure 10. MESOPAC II SCS watergun profile from the PB (right side) to the EMB crossing approximately perpendicular to the inferred trend of the Ogasawara Fracture Zone. The seismic image is strikingly similar to those across the Hawaiian flexural moat (Rees et al., in press). Reflections clearly show onlapping geometries interpreted as moat-filling debris flows and turbidites derived from the Magellan Seamounts. These seamounts are aligned along the trend of the Ogasawara Fracture Zone and appear to flexurally depress high-velocity Horizon B over a $120 \mathrm{~km}$ range (e.g., flexural wavelength) on the PB side of the fracture zone. This near-channel record is processed and displayed with the following parameters: mute, 2-trace mix, band-pass filter $25-100 \mathrm{~Hz}$, water-velocity $\mathrm{F} / \mathrm{K}$ migration, $500 \mathrm{msec}$ AGC, and vertical exaggeration $\sim 53 \mathrm{X}$ at $1.5 \mathrm{~km} / \mathrm{s}$. 

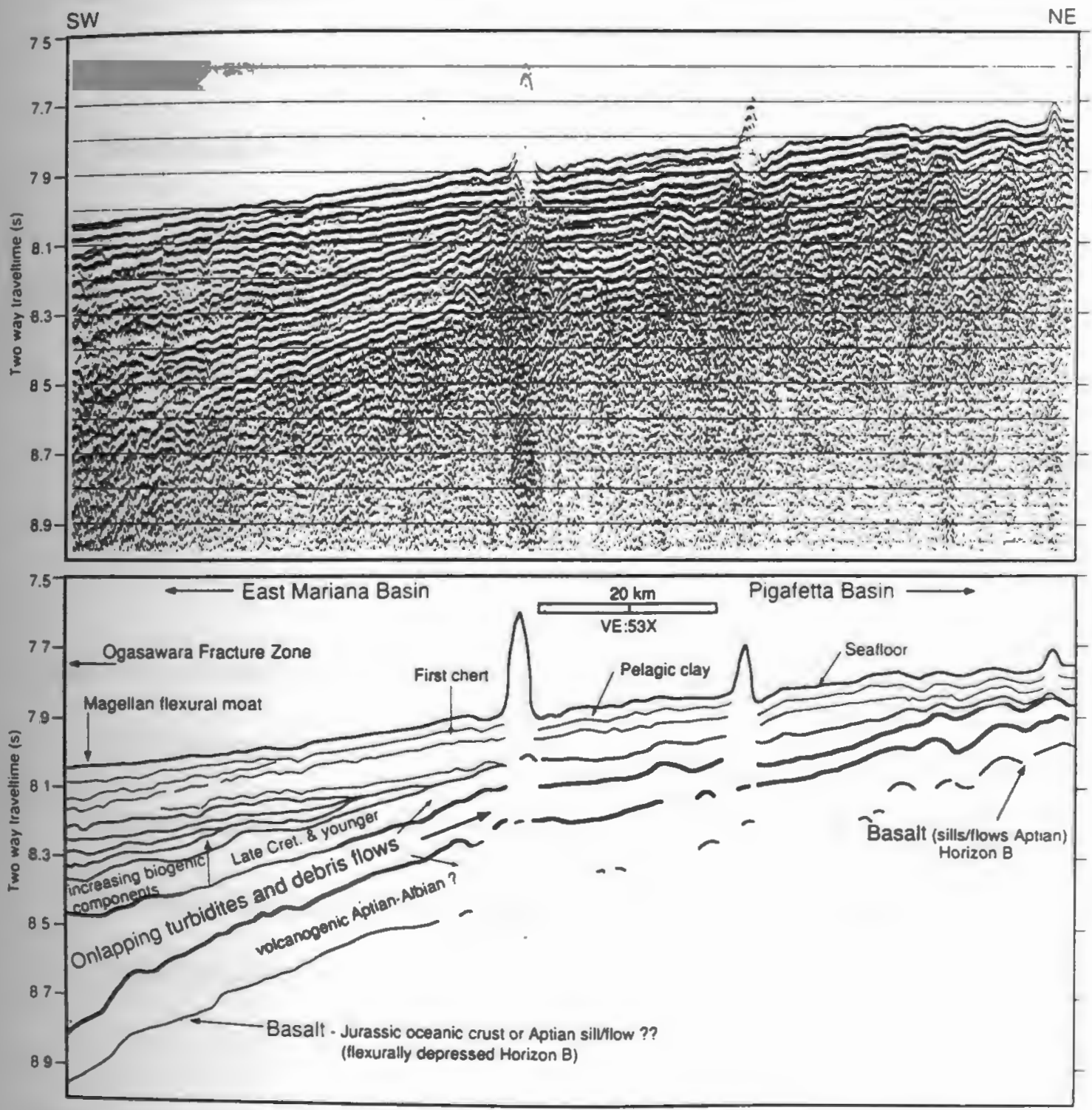


\section{REFERENCES}

Abrams, L. J., Larson, R. L., Shipley, T. H., and Lancelot, Y., 1988. Cretaceous volcanic sequences and Jurassic(?) crust in the western Pacific. Trans. Am. Geophys. Un., 69:1442.

Abrams, L. J., Larson, R. L.,Shipley, T. H., and Lancelot, Y., in press. Cretaceous volcanic sequences and Jurassic crust in the East Mariana and Pigafetta Basins of the western Pacific, In Pringle, M., and W. Sager (Eds.) The Mesozoic Pacific, AGU Monogr. Ser.

Arthur, M. A., Dean, W. A., and Schlanger, S. O., 1985. Variations in the global carbon cycle during the Cretaceous related to climate, volcanism, and changes in atmospheric $\mathrm{CO}_{2}$, in Sundquist, E.T., and W.S. Broecker (Eds.), The Carbon Cycle and Atmospheric $\mathrm{CO}_{2}$ : Natural Variations Archean to Present. AGU Monogr. Ser. 32: 504-529.

Arthur, M. A., Kump, L. R., Dean, W. E., and Larson, R. L.,1991. Superplume, supergreenhouse?. Trans. Am. Geophys. Un., 72:301.

Batiza, R., 1981. Lithospheric age dependence of off-ridge volcano production in the 
North Pacific, Geophys. Res. Lett. 8, 853-856,

Batiza, R., Fornari, D., Vanko, D., and Londsdale, P.,1984. Craters, calderas and hyaloclastites on young Pacific seamounts. L.Geophys. Res., 89:8731-8390.

Carey, S. N., and Sigurdsson, H., 1980. The Roseau Ash: deep-sea tephra deposits from a major eruption on Dominica, Lesser Antilles Arc. J. Volcan. Geotherm. Res., 7: 67-86.

Crough, S. T., 1983. The correction for sediment loading on the seafloor. L. Geophys. Res., 88:6449-6454.

Edgar, N. T., Saunders, J. B., et al., 1973. Init. Repts. DSDP, 15: Washington, D.C. (U.S. Govt. Printing Office).

Ewing, J., Talwani, M., Ewing, M., and Edgar, T., 1967. Sediments of the Caribbean. temational Conference on Tropical Oceanography Proc., 5:88-102.

Ewing, J., Ewing, M., Aitken, T., and Ludwig,W. J., 1968. North Pacific sediment layers measured by seismic profiling. In Drake, C. L., and Hart, P.J. (Eds.), The and Upper Mantle of the Pacific Area. Am. Geophys. Un. Monogr., 


\section{2:147-173.}

Fisher, A. G., Heezen, B. C., et al., 1971. Init. Repts. DSDP 6: Washington, D.C. (U.S. Govt. Printing Office).

Handschumacher, D. W., and Gettrust J. F., 1985. Mixed polarity model for the Jurassic "Quiet Zones": new oceanic evidence of frequent pre-M25 reversals. Trans. Am. Geophys. Un., 66: 867.

Handschumacher, D. W., Sager, W. W., Hilde, T.W.C., and Bracey, D. R., 1988. Pre-Cretaceous tectonic evolution of the Pacific plate and extension of the geomagnetic polarity reversal time scale with implications for the origin of the Jurassic "Quiet Zone". Tectonophysics, 155:365-380.

Harland, W. B., Armstrong, R.L., Cox, A.V., Craig, L. E., Smith, A. G., Smith, D. G., 1990. A Geologic Time Scale 1989, Cambridge, (Cambridge Univ. Press).

Heezen, B.C., MacGregor, I.D., Foreman, H.P., Forristal, G., Hekel, H., Hesse, R., Hoskins, R.H., Jones, E.J.W., Kaneps, A., Krasheninnikov, V.A., Okada, H., and Reuf, M.H., 1973. Diachronous deposits: a kinematic interpretation of the post Jurassic sedimentary sequence on the Pacific plate. Nature, 241:25-32. 
Hilde, T.W.C., Isezaki, N., and Wageman, J. M., 1976. Mesozoic seafloor spreading in the North Pacific. In Sutton, G.H., Manghnani, M.H., and Moberly, R. (Eds.), The Geophysics of the Pacific Ocean Basin and its Margins. AGU Geophys. Monogr. Ser., 19: 205-226.

Houtz, R. E., and W. J. Ludwig, 1977. Structure of Columbia Basin, Caribbean Sea, from profiler-sonobuoy measurements. J.Geophys. Res., 82, 4861-4868.

Jarrard, R. D., and Clague, D. A., 1977. Implications of Pacific island and seamount ages for the origin of volcanic chains. Rev. Geophys. and Space Phys., 15:57-76.

Keating, B. H., Mattey, D. P., Naughton, J., and Helsley, C. E., 1984. Age and origin of Truk Atoll, eastern Caroline Islands: Geochemical, radiometric-age, and paleomagnetic evidence. Geol.Soc.Am. Bull., 95:350-356.

Kent, D. V., and Gradstein, F. M., 1985. A Cretaceous and Jurassic geochronology. Geol. Soc. Am. Bull., 96:1419-1427.

Lancelot, Y., and Larson, R. L., 1975. Sedimentary and Tectonic Evolution of the Northwestern Pacific. In Larson, R. L., Moberly, R., et al., Init. Repts. DSDP 
32: Washington, D.C. (U.S. Govt. Printing Office), 925-939.

Lancelot, Y., Larson, R. L., et al., 1990. Proc. ODP. Init. Repts., 129: College Station, TX (Ocean Drilling Program).

Larson, R. L., and Chase, C. G., 1972. Late Mesozoic evolution of the western Pacific Ocean. Geol. Soc. Am. Bull., 83:3627-3644.

Larson, R. L., Moberly R., et al., 1975. Init. Repts. DSDP. 32: Washington, D.C. (U.S. Govt. Printing Office).

Larson, R. L., and Lowrie, W., 1975. Paleomagnetic evidence for motion of the Pacific plate from Leg 32 basalts and magnetic anomalies. In Larson, R. L., Moberly, R., et al., Init. Repts. DSDP 32: Washington, D.C. (U.S. Govt. Printing Office), 571-577.

Larson, R. L., 1976. Late Jurassic and Early Cretaceous evolution of the western central Pacific Ocean. L. Geomag. Geoelectric, 28: 219-236.

Larson, R. L., Schlanger, S.O., et al., 1981. Init. Repts. DSDP 61: Washington, D.C. (U.S. Govt. Printing Office). 
Lowrie, A., Smoot, C. N., and Batiza, R., 1986. Are oceanic fracture zones strong or weak? New evidence for volcanic activity and weakness. Geology, 14:242-245.

Macdonald, K. C., 1982. Mid-ocean ridges: Fine scale tectonic, volcanic and hydrothermal processes within the plate boundary zone. Ann. Rev. Earth Planet. Sci., 10:155-190.

Mammerickx, J., and Sharman, G.F., 1988. Tectonic evolution of the North Pacific during the Cretaceous quiet period. J.Geophys, Res., 93: 3009-3040.

Moberly, R., Schlanger, S.O., et al., 1986. Init. Repts. DSDP 89: Washington, D.C. (U.S. Govt. Printing Office).

Nakanishi, M., Tamaki, K., and Kobayashi, K., 1989. Mesozoic magnetic anomaly lineations and seafloor spreading history of the northwestem Pacific. J. Geophys. Res., 94:15,437-15, 462.

Nakanishi, M., K. Tamaki, and K. Kobayashi, in press. Magnetic anomaly lineations from Late Jurassic to Early Cretaceous in the west-central Pacific Ocean, Geophys. Int. 
Ozima, M., I. Kaneoka, K. Saito, M. Honda, M. Yanagisawa, and Y. Takigami, 1983. Summary of geochronological studies of submarine rocks from the western Pacific Ocean. In Hilde, T.W.C., and Uyeda, S. (Eds.), Geodynamics of the Western Pacific-Indonesian Region, vol.11, 137-142.

Renkin, M., and Sclater, J. G., 1988. Depth and Age in the North Pacific. L.Geophys. Res., 93:2919-2935.

Pringle, M., Duncan, R., Smith, W., and Staudigel, H., 1990. Cretaceous Pacific hotspot tracks. Trans. Am. Geophys. Un., 71: 1673.

Pringle, M., 1992. Geochronology and petrology of the Musicians Seamounts and the search for hot spot volcanism in the Cretaceous Pacific. [Ph.D. dissertation], University of Hawaii, Honolulu.

Rees, B. A., R. S. Detrick, and Coakley, B. C., in press. Seismic stratigraphy of the Hawaiian flexural moat, Bull. Geol. Soc. Am.

Sager, W. W., and Pringle, M. S., 1988. Mid-Cretaceous to Early Tertiary apparent polar wander path of the Pacific plate. L.Geophys. Res., 93:11,753-11,771. 
Sager, W. W., Handschumacher, D. W., Hilde, T.W.C., and Bracey, D. R., 1988. Tectonic evolution of the northem Pacific plate and Pacific - Farallon - Izanagi triple junction in the Late Jurassic and Early Cretaceous (M21-M10). Tectonophysics, 155:345-364.

Saunders, J. B., Edgar, N. T., Donnelly, T. W., and Hay, W. W., 1973. Cruise synthesis. In Edgar, N. T., Saunders, J. B., et al., Init. Repts. DSDP 15: Washington, D.C. (U.S. Govt. Printing Office), 1077-1111.

Schlanger, S. O., Jenkyns, H. C., and I. Premoli-Silva, 1981. Volcanism and vertical tectonics in the Pacific basin related to global Cretaceous transgressions. Earth Planet. Sci._Lett., 52: 435-449.

Schmincke, H.-U., and von Rad, U., 1979. Neogene evolution of Canary Island volcanism inferred from layers and volcaniclastic sandstones of DSDP Site 397. Init. Repts. DSDP 47:, Pt. 2, Washington, D.C. (U.S. Govt. Printing Office), 703716.

Shipboard Scientific Party, 1971. Site 61. In Winterer, E. L., Reidel, W. R., et al., Init. Repts. DSDP 7, Pt. 1: Washington, D.C. (U.S. Govt. Printing Office), 27-48. 
Shipboard Scientific Party, 1973. Mesozoic chalks beneath the Caroline abyssal plain: DSDP Site 199, In Heezen, B. C., MacGregor, I.D., et al., Init. Repts, DSDP. 20: Washington, D.C. (U.S. Govt. Printing Office), 65-85.

Shipboard Scientific Party, 1990a. Site 800. In Lancelot, Y., Larson, R. L., et al., Proc. ODP. Init. Repts., 129: College Station, TX (Ocean Drilling Program), 33-89.

Shipboard Scientific Party, 1990b. Site 801.In Lancelot, Y.,Larson, R. L., et al.,Proc. ODP. Init. Repts., 129: College Station, TX (Ocean Drilling Program), 91-170.

Shipboard Scientific Party, 1990c. Site 802. In Lancelot, Y., Larson, R. L., et al., Proc. ODP. Init. Repts., 129: College Station, TX (Ocean Drilling Program), 171-243.

Shipley, T. H., Whitman, J. M., Duennebier, F. K., and Peterson, L. D., 1983. Seismic stratigraphy of the East Mariana Basin, western Pacific. Earth Planet.Sci. Lett., 64: 257-275.

Sigurdsson, H., Sparks, R.S.J., Carey, S. N., and Huang, T. C., 1980. Volcanogenic sedimentation in the Lesser Antilles Arc. J. Geol., 88:523-540.

Smith, W.H.F., Staudigel, H., Watts, A. B., and Pringle, M.,1989. The Magellan 
Seamounts: Early Cretaceous record of the South Pacific isotopic and thermal anomaly. J.Geophys. Res., 94: 10,501-10,523.

Tamaki, K. and Larson, R. L., 1988. The Mesozoic tectonic history of the Magellan microplate in the Western Central Pacific. L. Geophys. Res., 93:2857-2874.

Tamaki, K., Nakanishi, M., Sayanagi, K., and, Kobayashi, K., 1987. Jurassic magnetic anomaly lineations of the Westem Pacific and the origin of the Pacific plate. Trans. Am. Geophys. Un., 68:1493.

ten Brink, U.S., and Watts, A. B., 1985. Seismic stratigraphy of the flexural moat flanking the Hawaiin Islands. Nature, 312: 421-424.

Vogt, P. R., 1974. Volcano spacing, fractures and thickness of the lithosphere. Earth Planet. Sci. Lett., 21:235-252.

Whitman, J.M., Baltuck, M., and Haggerty, J. A., 1986. Turbidite sedimentology and history of the East Mariana Basin, In Moberly, R., Schlanger, S. O., et al., Init. Repts. DSDP 89: Washington, D.C. (U.S. Govt. Printing Office), 365-387.

Winterer, E. L., Duncan, R. A., McNutt, M. K., Natland, J. H., Premoli Silva, Isabella, 
Sager, W. W., Sliter, W. V., Van Waasbergen, R., and Wolfe, C. J., in press. Cretaceous guyots in the northwest Pacific: An overview of their geology and geophysics, In Pringle, M., and W. Sager (Eds.) The Mesozoic Pacific, AGU Monogr. Ser. 


\section{MANUSCRIPT III}

Comparison of Laboratory and Logging Data from Leg 129

and the Inversion of Logs to Determine Lithology 


\section{ABSTRACT}

Coring during ODP Leg 129 in the western Pacific resulted in poor to fair recovery, often less than $10 \%$, meaning that sedimentary sections have been poorly characterized through description of the cores. This study is an attempt to better characterize the sediments over parts of the drilled intervals, using continuous wireline-logging measurements. Laboratory and log data are presented and compared to establish which intervals are well represented by the recovered cores. Rebound corrections are applied to sediments containing a significant proportion of clay, as these materials seem to have most closely followed standard compactional trends for deep-sea sediments. Laboratory and log measurements are then used to establish five idealized lithotypes, end-member components that can be mixed to generate a variety of sediment compositions and properties. The log data are then inverted to determine the proportions of each of these lithotypes represented at every measurement depth. Examination of trends in the proportions of the five lithotypes reveals sedimentological relationships that were not apparent in the cores, largely because core recovery was strongly biased. The results of this exercise are qualitatively satisfying, but more quantitative $\log$ inversion would probably require significantly higher recovery in order to constrain possible lithotypes, both physically and chemically.

\section{MNTRODUCTION}

Three sites were drilled and cored during Ocean Drilling Program (ODP) Leg 129 to 
the Pigafetta and East Mariana basins, yielding a wide variety of sediment and rock types and ages. One to four samples of typical lithologies from every core were collected and run through a series of standard tests to determine physical properties. Wireline logs were also run at all three sites in an effort to obtain continuous data from the sedimentary section; these logs cover only a part of the sedimentary section at each site, and no logs were run in basement. The logs are particularly important because overall recovery within the sedimentary sections was fair to poor. Several hundred-meter intervals are characterized by rock representing $<5 \%$ of that drilled and cored.

The purpose of this study is to use physical properties and log measurements made during the cruise, and geochemical data collected after the cruise, to (1) better characterize the physical state of the sediments, (2) establish some degree of ground-truth for both lab and borehole measurements, and (3) provide a qualitative assessment of the distribution of lithotypes that would be present in "representative" sections from these sites, if such complete records could be obtained.

Tents Drilled and Cored during Leg 129

Site 800 was the first drilled during Leg 129 , and is located in the northeastern Pigafetta Basin, at about $22^{\circ} \mathrm{N}$ (Fig. 1; Angell et al., this volume; Shipboard Scientific Party, 1990a). Sediments from Site 800 range in age from younger than Pliocene to Early Gretaceous, with the greatest representation by Aptian and Albian material. The Redimentary section was divided into five primary lithologic units by the shipboard scientific party, only three of which include significant coverage by wireline logs: Unit II : 
brown chert and porcellanite; Unit III - gray chert and limestone; and Unit IV - redeposited volcaniclastics (mainly sandstone, siltstone and claystone). Recovery ranged from extremely poor in units II and III $(3.5 \%-7.3 \%, 5.1 \%$ overall) to excellent in parts of unit IV ( $>80 \%$ in some cores, $42.7 \%$ overall). Although these divisions, and those that followed at the remaining sites, appear to be obvious from the core descriptions and site chapters in Lancelot, Larson et al. (1990), a quick examination of the barrel sheets and logs reveals that each lithologic unit is actually a complex mixture of many different sediment types. In general, the lithologic unit boundaries were positioned at the first significant occurrence of a major lithologic change (usually a change in sediment type that suggested a change in depositional facies), although for any particular unit, sediments typical of overlying and underlying units commonly appear throughout (Lancelot, Larson et al., 1990).

Two holes included coring within the sedimentary section at Site 801 (Fig.1; Angell et al., this volume; Shipboard Scientific Party, 1990b), yielding five lithologic units, three of which were covered by wireline logs: Unit II - brown chert and porcellanite; Unit III volcaniclastic turbidites and minor pelagic intervals; and Unit IV - brown radiolarite. Unit III provided poor-fair recovery (20.9\% overall) whereas recovery in Units II and IV was extremely poor, averaging only $4.8 \%$. Sediments at Site 801 ranged in age from younger than Paleocene to Middle Jurassic, with the greatest representation of mid-Cretaceous material. Although Site 801 is located about $500 \mathrm{~km}$ to the southeast of Site 800 , several of the lithologic units appear to correlate well between the sites, in terms of their 
compositions, if not ages: Site 800 , Unit II correlates with Site 801, Unit II; Site 800 , Unit IV correlates with Site 801, Unit III; and Site 800, Unit V correlates with Site 801, Unit IV (Karpoff, this volume; Shipboard Scientific Party, 1990a,b). This correlation allows some comparison and combination of physical properties and log responses in order to characterize the typical properties of individual sedimentary units, as described later.

A single hole was drilled at Site 802 , located in the East Mariana Basin, approximately $830 \mathrm{~km}$ southwest of Site 801 (Fig. 1; Angell et al., this volume; Shipboard Scientific Party, 1990c). Sediments recovered while drilling Hole 802A ranged in age from Quaternary to Early Cretaceous, with the greatest representation by Miocene material. These materials yielded nine lithologic units, only two of which were logged: Unit II volcaniclastic turbidite tuffs, and Unit III - nannofossil chalk. Recovery was poor to good in both of these units, ranging from $2 \%$ to $80 \%$, and was $23.4 \%$ overall. This site was separated from those in the Pigafetta Basin by a major morphotectonic boundary, a seamount province, and fracture zone, which strongly influenced sediment distribution; sediments in units II and III at Site 802 do not correlate well (by age or composition) with sediments from either Site 800 or 801 (Shipboard Scientific Party, 1990c).

\section{Biased Sampling}

In addition to being extremely poorly sampled overall because of low recovery, many of the lithologic units recovered during Leg 129 were sampled nonrepresentatively. For example, the small chunks of chert and limestone brought back to the surface when 
cutting cores from lithologic Unit III in Hole $800 \mathrm{~A}$ are a biased sample of the sediments penetrated, as there is good evidence that these two lithologic types comprise less than half of the stratigraphic sequence of the unit. First, the drillers reported alternating hard and soft intervals, particularly when penetrating intervals where very hard materials such as chert, limestone, porcellanite, and radiolarite were the only rocks recovered (and where recovery was typically extremely low). Second, the interval velocities determined from site surveys in this area indicate that the average acoustic velocity through the sedimentary sections is near $2 \mathrm{~km} / \mathrm{s}$ at all three sites, yet the hard lithologies listed previously yielded significantly greater laboratory velocities (Lancelot, Larson et al., 1990). Similarly, sonic logs through several intervals that yielded low recovery of only very hard material suggest in-situ sediment velocities that are significantly lower than the velocities measured on samples from cores within these intervals.

Additional biases were also introduced because of the specific interests of the shipboard party and the techniques used for sample collection and testing. Several specialists sampled primarily silica-rich intervals (Behl et al., this volume; Karl and Karpoff., this volume) whereas others measured the bulk geochemistry of samples that could be squeezed for pore fluids (France-Lanord et al., this volume). As a result, our knowledge of the composition of materials drilled and cored during Leg 129 is not only limited, but also strongly skewed.

\section{EXPERIMENTAL METHODS}


Shipboard physical properties and logging measurement techniques are described in detail in Lancelot, Larson et al. (1990), and only a brief review is provided here. Within each core, shipboard physical-properties scientists sampled both representative and unusual lithologic types to characterize the recovered materials. Volumes of dry samples (approximately $10 \mathrm{~cm}^{3}$ ), determined using a helium-displacement pycnometer, and wet and dry masses, measured with an electronic balance, were used to calculate bulk and grain densities, porosities, and water contents. These data were checked by gamma-ray attenuation techniques using the GRAPE (Boyce, 1976) and found to be reproducible to within about 5\%. Salt corrections were applied as per Hamilton (1971). Some samples of extremely hard and nonporous lithologies were powdered to more accurately determine grain densities. Compressional-wave velocities were determined using a Hamilton frame velocimeter, with an estimated accuracy of about $2 \%$ (Boyce, 1976). Residues from index properties measurements were tested for calcium carbonate content using a coulometer, with an estimated error of about $1 \%$.

Standard logging runs during Leg 129 included a quad-combination string (longspaced sonic, dual-induction, natural spectral gamma, and high-temperature lithodensity tools) and a geochemical combination string (natural spectral gamma, induced spectral gamma, and aluminum clay tools). These tools all have different sampling intervals, depths of investigation, and sensitivities to hole conditions. Complete descriptions of the tools can be found in the Ocean Drilling Program Logging Manual (Borehole Research Group, 1990). Logs were recorded in all cases through as much open hole as was 
available. Because the logs were run last, often after many days of coring and drilling, deteriorating hole conditions allowed only parts of each hole to be logged (Lancelot, Larson et al., 1990).

Log records from the different strings run in the same hole were depth-shifted to match natural gamma readings, where possible. In Hole $801 \mathrm{~B}$, the lithodensity and natural gamma tools were run out of sequence, resulting in irradiation of the formation immediately before measurement of "natural" radiation levels. Depth-shifting in Hole $801 \mathrm{~B}$, therefore, required a more subjective matching of natural gamma and other tracks from the geochemical.string and with physical-property records from the quadcombination string. Log depths were tied to core depths (that is, depth below the seafloor) based on the identification of the seafloor and/or the end of the pipe and the driller's depth records.

The caliper from the lithodensity tool was used to measure borehole size to identify washed-out zones and correct the responses of tools to borehole variations. Records from the long-spaced sonic tool were processed aboard ship to remove noise and unrealistic velocities caused by cycle skips (Lancelot, Larson et al., 1990). Data from the geochemical combination string were subjected to significant post-cruise processing, as described in (Hertzog et al., 1989) and Pratson et al. (this volume). The field data were first corrected for logging speed, pipe effects, and the presence of mud added to the borehole to maintain hole stability. Relative elemental yields were then determined for a maximum of nine elements. Total radioactivity and Th, $\mathrm{U}$, and $\mathrm{K}$ concentrations were 
calculated with data from the natural spectral gamma tool, and $\mathrm{Al}$ concentrations were calculated with data from the aluminum clay tool, with a correction applied for silicon interference. $\mathrm{Al}$ and $\mathrm{K}$ elemental yields were then normalized to allow for the calculation of elemental, dry-weight fractions. These fractions were, in tum, used to estimate dry-weight fractions of individual oxides. Comparison of geochemical $\log$ and laboratory data has often revealed accuracy for elements better than 3\% (van den Oord, 1990; Wentdlandt and Bhuyan, 1990; Cannon and Coates, 1990).

The geochemical logging tools were developed primarily for oil field applications. As such, the tools have generally been tested and calibrated within lithologies typical of these settings. For example, the conversions from elemental yields to oxide abundances are based on experimental data from "typical" sedimentary rocks (Pratson et al., this volume), which may not be typical of those materials logged during Leg 129. As elemental responses are not expected to be linear with concentration (Hertzog et al., 1989), the exotic nature of some Leg 129 lithologies adds significant uncertainty to the interpretations based on geochemical logging data. In addition, much of the geochemical log calibration and processing is proprietary, meaning that the exact procedures are not available to the scientific community.

Logging data collected on the Resolution were recorded every $0.1524 \mathrm{~m}(6 \mathrm{in}$.$) . In$ order to directly compare log measurements from different strings, reduce the number of data points to a more manageable quantity, and allow for cross-plotting and ratioing, we passed the data through a $0.5-\mathrm{m}$ boxcar-averaging filter, with final depths chosen at 
regular $0.5 \mathrm{~m}$ intervals relative to the seafloor (i.e., 55.0, 55.5, 60.0,...m below seafloor [mbsf]). All logs presented in this paper have been filtered using the same scheme; examination of the final curves suggests that significant character remains after filtering.

\section{Physical Properties Rebound Corrections}

In the following sections, we have grouped data by lithotype and plotted all properties as a function of depth to examine compactional influences on physical properties. Compaction is a function of time, not just depth (e.g., Busch, 1989), but this simple approach allows elucidation of several important relationships. Figure 2 reveals that only the clay and claystone samples collected during Leg 129 display a significant compaction with depth. In particular, the chert, limestone, porcellanite, radiolarite, and chalk samples display no coherent variations in porosity with depth. Several chert samples collected from above $100 \mathrm{mbsf}$ are somewhat higher in porosity (and correspondingly lower in density) than those found below 300 mbsf, but within each group there is no strong trend. Sandstone and tuff samples display a slight decrease in porosity with depth and siltstone samples reflect a significantly greater compactional trend, but clay and claystone samples fall squarely between the pelagic clay and terrigenous sediment curves defined by Hamilton (1976). This finding suggests that, to a first order, only the index properties of clay and claystone samples need be corrected for rebound due to removal from in-situ conditions. Some caution must be applied in making this interpretation, as there may have been insufficient time for the samples to rebound fully between collection and testing. For this reason, we have chosen to apply the smaller of the rebound 
corrections suggested by Hamilton (1976) for clay-rich sediments, that for terrigenous clay (Fig. 2A). No porosity correction has been applied to data from chalk samples, mainly because these data do not display a coherent trend with depth (Fig. 2B). In addition, within an appropriate range of porosities the acoustic properties of pelagic carbonate sediments may be somewhat less sensitive to interparticle porosity than they are to intraparticle porosity, changes in which do not depend directly on burial and compaction (e.g., Fulthorpe et al., 1989).

Cross-plots of bulk density and velocity vs. porosity of clay and silt-rich sediments (Fig. 3A) reveal consistent relationships between these properties (as is to be expected where grain density is relatively constant). We have used these relationships to calculate rebound corrections for bulk density and compressional-wave velocity by assuming that a change in porosity associated with rebound simply moves the other properties along the appropriate, best-fit curves in Figure 3. Plots of corrected bulk density and compressionalwave velocity vs. depth (Fig. 4) also illustrate the relative insensitivity of all lithologies except clay and claystone to the mechanical consolidation associated with burial. This observation could mean that the materials that formed the other lithologies did not experience mechanical compaction, or that mechanical effects have been overprinted by later diagenesis.

\section{LOGGING AND LABORATORY PHYSICAL-PROPERTIES DATA}

Log and laboratory measurements are directly compared in Figures 5-7, following 
application of the corrections discussed previously. Depth errors may have been introduced in core-log depth correlations. Many errors are introduced as a result of differential drill-pipe and wireline stretch and heave. In addition, all recovered core has been pushed to the top of the cored interval for archival purposes, as is standard ODP procedure.

We have confidence in the overall quality of the density and velocity logs in Hole $800 \mathrm{~A}$ because of the strong, nearly peak-for-peak, correlation between the two. There is also excellent agreement between laboratory and borehole density measurements within the interval of 220-280 mbsf (mainly Unit IV, redeposited volcaniclastics). The agreement between the measurements at $160-220$ mbsf is also surprisingly good, considering the extremely poor recovery and biased sampling in this section. Significantly higher laboratory density measurements between 40 and 160 mbsf are not surprising considering the preferential core recovery in the chert and limestone of lithologic units II and III.

Velocity measurements from Hole 800A follow similar trends, with excellent agreement between 220 and $260 \mathrm{mbsf}$, and significantly poorer agreement at lesser depths. It is not immediately apparent what happened below $150 \mathrm{mbsf}$ that allowed the two data sets to match so closely, but this is the approximate depth below which claystone and chalk appear in cores within the chert and limestone of lithologic Unit III. It may be that these constituents were also present in the shallower portions of the section, but were too soft and unlithified to allow recovery.

We inverted the medium-depth resistivity log derived from the dual-induction tool 
to look at in-situ porosity trends, with poor results. The empirical Archie (1942) relationship for clean quartz sandstone is known to break down in unlithified to semilithified, high-porosity materials, and when clay content is greater than a few percent (e.g., Waxman and Smits, 1968; Clavier et al., 1977) because the measured resistivity includes contributions from both free water in pores and bound water on clay minerals. Although the absolute correlation between.laboratory porosities and $\log$ porosities determined with Archie's Law is poor, there are zones within which the two curves follow similar trends; these are the same zones over which there is a good correlation between shipboard and log density and velocity data.

Also shown in Figure 5 (and in Figs. 6 and 7 for Sites 801 and 802, respectively) is a synthetic porosity log calculated from the borehole bulk density curve, an assumed pore-fluid density of $1.050 \mathrm{~g} / \mathrm{cm}^{3}$ (appropriate for seawater at $6000 \mathrm{~m}$ water depth; Neumann and Pierson, 1966), and an average grain density based on the weight percentages of individual lithologies determined with the inversion procedure described later in this paper. The porosity data show trends that correspond to those of the other hysical-properties data; the variable goodness of fit of the laboratory porosity data to the synthetic porosity log support the inference that the laboratory data are representative only within zones over which recovery was relatively high.

At Site 801, the section from about 190 to 270 mbsf displays remarkable agreement between borehole and corrected laboratory physical-properties data (Fig. 6). Again, the materials that dominate this interval are redeposited volcaniclastic sediments. Chert- and 
radiolarite-rich sections reveal less consistent trends. The fit between the lab and borehole data is best overall in Hole 802A (Fig. 7). There is general agreement throughout the logged section, with an excellent match below about 200 mbsf. The logged interval in Hole $802 \mathrm{~A}$ is composed almost entirely of volcaniclastic tuff, claystone, and chalk, which seem to have allowed for the most representative core sampling of the drilled formation, despite the relatively low recovery.

The corrected laboratory data provide a means to check the consistency of borehole measurements, particularly within zones of good recovery where we have high confidence that the core is representative of the drilled section. In all cases where recovery was good ( $>60 \%-70 \%)$ the match between physical-properties measurements and corresponding logs is excellent. If borehole conditions were sufficiently good for the lithodensity tool, which is highly sensitive to borehole irregularities, conditions within the same zones should have been good for other logs as well. Within identifiable zones in these intervals that contain a single lithology, individual properties or characteristics of that lithology can be determined. If a zone assumed to contain a single lithology actually contains a mixture of several lithologies, characterization of any one will be impossible without an a priori estimate of the relative proportions and properties of the other constituents.

\section{Mean Properties}

The consistency of physical properties as a function of lithology (rather than depth or degree of compaction) is evident when individual measurements are averaged using samples that appeared to be composed of mainly one lithology (Fig. 8). At either end of 
the physical-properties spectrum are the chert and pelagic clay samples. The differences between these materials and all others are large enough to make a reasonable lithologic identification possible, based on only one or two measurements. For example, the chert samples had significantly higher velocities than all other materials (about $4.8 \mathrm{~km} / \mathrm{s}$ ), and the average would be even higher (and the standard deviation lower) if the three shallow, porous chert samples from Sites 800 and 801 were not included. Partly because of scatter in the data, as evident from the large standard deviations associated with each mean, several of the lithotypes seem to be indistinguishable based only on their physical properties. The mean velocities, densities, and porosities for radiolarite and chalk are almost identical, although their chemical and textural differences are sufficient to distinguish them in hand sample.

Porcellanite and the sandy Miocene tuff (found only at Site 802) have similar mean velocities; however it is simple to separate the two because they have sufficiently different porosities and bulk and grain densities (Fig. 8). The lower grain density of the sandy tuff from Site 802 in comparison with the sandy portions of the Cretaceous turbidites from Sites 800 and 801 may reflect the larger feldspar and glass content of the former. Several of the differences in classification directly reflect properties, or degree of diagenesis, rather than initial composition. For example, the distinction between chert and porcellanite made by shipboard sedimentologists was largely one of hardness, although the major control on these properties may be the initial silica/clay ratio (Lancelot, Larson et al., 1990). Radiolarite and chert may similarly be at ends of a diagenetic spectrum, which depends 
largely on the clay content of the sediment, as described by Behl et al. (this volume).

Ormparison of Borehole. Laboratory. and Seismic Interval Velocities

Examination of sonic logs from Leg 129 provides strong evidence that we do not have a good understanding of the composition of the sedimentary section drilled at the three sites. Figure 9 illustrates a comparison of interval slowness estimated from the correlation of seismic reflectors with lithologic boundaries, and slowness determined using the long-spaced sonic tool. Over complete logged intervals, the sonic slowness is within one standard deviation of the inferred interval slowness. The weighted fit for Sites 800 and 802 is actually quite good, and the fit for Site 801 somewhat less so. When the individual seismic intervals are examined, however, the match is less assuring. Zones predicted to have low slowness (high velocities) from seismic picks have higher sonic-tool slowness (lower velocities), whereas other zones predicted from the seismic picks to have high slowness (low velocities) have lower sonic-tool slowness (higher velocities). It is not expected that the seismic and sonic data will be a perfect match, particularly because only portions of some seismic intervals were logged; a good match of seismic and sonic velocities within these intervals would require that average velocities apply across each. Velocities of complete seismic intervals over which the sonic tool was run should match, however.

The interval velocities reported by the Shipboard Scientific Party $(1990 \mathrm{a}, \mathrm{c})$ for Sites 800 and 802 were estimated from synthetic seismograms derived from logged velocity and density measurements, whereas the interval velocities for Site 801 were estimated without 
the guidance of log-generated synthetic seismograms. The detail presented for the interval velocities (Shipboard Scientific Party, 1990a, figure 42; Shipboard Scientific Party, 1990b, figure 57; Shipboard Scientific Party, 1990c, figure 58) was poorly constrained, particularly at Site 801 , although there are several correlatable seismic and lithologic horizons that should provide a reasonable estimate for average sediment velocities.

There appears to be a good correlation between seismic reflections and cored lithologies at the following sub-seafloor boundaries: the top of Upper Cretaceous chert and porcellanite units at Sites 800 and 801 (Unit II in both cases); the top of a massive chert bed at the base of, or bounding, Unit III at Site 801; the top of the first abundant chert interval within the chalky part of Unit II at Site 802; and the top of massive igneous units at all three sites (Jurassic igneous basement at Site 801; mid-Cretaceous sills at Site 800; mid-Cretaceous flows at Site 802). Combined with a good reflector at the seafloor, these correlations suggest average velocities for the sedimentary sections of approximately 2.0 $\mathrm{km} / \mathrm{s}$ at Sites 800 and 801 and $1.9 \mathrm{~km} / \mathrm{s}$ at Site 802 (Abrams et al., this volume). These interval velocities are consistently lower than the sonic-log velocities determined from averaging travel times over the logged intervals (Sites 800 and $801: 2.2 \mathrm{~km} / \mathrm{s}$; Site 802: $2.1 \mathrm{~km} / \mathrm{s}$ ). The sonic-log velocities covary consistently with the resistivity, gamma-ray, and bulk-density logging data, which indicates that at least the relative changes in logged velocities are correct. It is these changes in velocities that provide a necessary discriminant for the inversion exercise that follows. rison of Log and Laboratory Geochemical Data 
Figures 10-12 illustrate processed geochemical log data plotted with laboratory data from the three sites. Within the chert-rich intervals, laboratory silica contents tend to exceed those calculated from log measurements, which is not surprising as cherty lithologies tended to be (1) preferentially recovered, and (2) preferentially sampled by chert specialists who provided most of the data over these intervals (Behl, this volume; Karl and Karpoff, this volume). The Site 800 laboratory data for the other major oxides used in this study match the log-derived oxides well (Fig. 10). At Site 801, log-derived silica oxide contents are again lower than those determined in the laboratory, particularly in the uppermost volcaniclastic turbidites of lithologic Unit III (Fig. 11). The lab data from this interval also include preferentially sampled chert and porcellanite. These samples also yielded lower aluminum and iron oxide percentages than measured with logs. Calcium contents are low throughout the logged interval at this site (Fig. 11). The match between log- and lab-derived oxide contents appears to be fair to good at Site 802, where dominantly volcaniclastic tuff and chalk were logged (Fig. 12). This interval displays the widest range in variations of all oxides, making a realistic evaluation of the match between $\log$ and lab data difficult (particularly considering the lingering questions concerning corelog depth shifting). Some of the logged oxide contents appear to be unrealistically extreme at Site 802 (particularly silica and iron), which may reflect the use of the geochemical logging tool and standard processing outside the normally calibrated range.

\section{INVERSION OF LOGS FOR LITHOLOGY}


Since its introduction, the geochemical logging tool has been used to determine quantitative mineral assemblages, usually through inversion of calculated element and oxide abundances (e.g., Harvey et al., 1990). There are many techniques available to complete this inversion, and each has benefits and drawbacks. We have used selected physical properties logs in combination with calculated oxide percentages and several limiting assumptions to estimate the abundances of fixed lithotypes throughout the logged intervals of Sites 800,801 , and 802 .

As a first step in this exercise, we have defined a series of idealized "lithotypes" that have end-member compositions and properties. This approach contrasts with standard geochemical log inversions for mineralogy (e.g, van den Oord, 1990; Wentdlandt and Bhuyan, 1990; Pratson et al., this volume). We did not feel that we had sufficient data (either laboratory or borehole) or sufficient confidence in the borehole data (particularly at Site 802 ) to constrain the vast number of mineralogies apparent from $\mathrm{x}$-ray diffraction analysis, and hand-sample and thin-section examination (Lancelot, Larson et al., 1990). In addition, our primary interest was in determining the relative proportions of lithologies present in the chert-, radiolarite-, and limestone-rich intervals. Following completion of this first-order analysis, a more detailed mineralogical analyses could focus on the mineralogies within isolated intervals.

The use of linear inversion techniques is detailed elsewhere (Harvey et al., 1990); only a brief overview is presented here. We assume that the instrument response for each measurement used in the analysis varies in direct response to the proportion of each 
constituent, according to the following system of equations, expressed in matrix form:

$$
\left[\begin{array}{cccc}
X_{1,1} & X_{1,2} & \cdots & X_{1, m} \\
X_{2,1} & X_{2,2} & \cdots & X_{2, m} \\
\vdots & \vdots & \cdots & \vdots \\
1.0 & 1.0 & \cdots & 1.0
\end{array}\right] \times\left[\begin{array}{c}
p_{1} \\
p_{2} \\
\vdots \\
p_{n}
\end{array}\right]=\left[\begin{array}{c}
c_{1} \\
c_{2} \\
\vdots \\
1.0
\end{array}\right]
$$

where $n$ is the number of components in the natural system, $p_{n}$ is the proportion of each component, $m$ is the number of logs, $X_{n, m}$ is the response of each log to each component, and $c_{n}$ is the actual $\log$ signal. In this exactly-determined system, the matrix equation can be expressed as $\boldsymbol{X} ¥ \boldsymbol{p}=\boldsymbol{C}$, where the matrix $\boldsymbol{p}$ is the desired solution, and is easily determined through inversion.

We have elected to use a simple error minimization model based on an overdetermined system of equations to estimate the abundances of individual rock types. In an over-determined system, the inverted matrix equation is $p=\left(X^{T} X\right)^{-1} X$ c. In this formulation, there must be at least as many logs as there are components to be identified. The system will then be at least slightly over-determined as the unity relation (requiring that the decimal fractions of all final components must add up to one) provides one more constraint. In practice, it is desirable that there be at least several more logs than components, particularly in cases where the accuracy of individual logs or the consistency of chemical compositions of the individual components is in question.

Weights can be assigned to each log based on the expected accuracy and reliability of the signal, as well as the significance of the signal in differentiating lithotypes. In equation (2), these weights would be expressed as proportional factors against which the total signals $(c)$ are multiplied. When weights are included in an over-determined system, the proportions of individual components are determined through solution of the following 
matrix equation: $p=\left(X^{T} W X\right)^{-1} X^{T} W \quad c$, where $W$ is a diagonal matrix containing the elements of the weight vector (Harvey et al., 1990).

In order for the transform to be stable, there must be at least one log that clearly discriminates each component. For example, the bulk density log is useful for separating chert and clay components at Leg 129 sites, based on the widely different responses each of these lithologies typically provides (Fig. 8). If one part of the sedimentary section is assumed to be composed only of chert and clay, then only a single, good-quality density $\log$ is needed to assign the relative proportion of each present over that interval. The same log would be useless for separating radiolarite and chalk components, however, because of their similar responses (Fig. 8). A better discriminator in this latter case might be $\mathrm{CaO}$ content, as estimated from the geochemical tool.

As more components are added to the system, additional discriminatory logs are needed. A system composed entirely of chert, limestone, and clay would, at first, seem to require only two logs, perhaps density and sonic. All three lithologies have distinct densities and travel times (Fig. 8), suggesting that an exactly determined system of equations (three lithologies and three equations, two logs plus the unity relation) should be adequate to estimate the relative proportion of each component. The hitch in this case is that one of the three components (limestone) has properties that are intermediate compared to both properties of the other two components. Chert has the highest density and velocity, and clay the lowest of each. Thus, a linear system of chert, limestone, and clay, which includes only two physical indicators, is actually under-determined in a strict sense because the inverse problem is still underconstrained (i.e., an inversion using only these two logs does not allow for discrimination between a mixture of chert and clay from pure limestone). Adding an additional discriminator, such as calcium carbonate content, would allow the limestone component to stand out more clearly.

We have modified the basic approach to $\log$ inversion in several ways. Most 
importantly, we have elected to invert for idealized "lithotypes" rather than individual mineral components. This is equivalent in some ways to defining a series of electrofacies (Serra, 1986). We have taken this approach because it allows us to emphasize differences in density and velocity between distinct lithologies without introducing errors due to poorly understood, often empirical, mixing transforms. Standard chemical distinctions commonly used for mineralogical inversion are also used in this study, as individual lithotypes are assumed to have distinct mineralogical assemblages. We feel that this approach is necessary because we were unable to identify zones of truly pure mineralogy in the Leg 129 sediments at a scale of thickness and accuracy suitable for log calibration, whereas there are many samples and zones that are characterized by individual lithologies. The downside to inverting for lithotype, rather than mineralogy, is that the former includes an implicit interpretation with respect to the mineralogical composition of individual units. We feel this is a fair compromise, because the overriding assumption in any inversion is that the composition of possible components (be these lithological or mineralogical) is known to be from a finite list that is selected prior to the computation. This assumption introduces the greatest uncertainty in the calculations. At best, this analysis will result in an overall composition that is reasonable within the uncertainty of the measurements; this composition must still be justified on additional, geological or geophysical, grounds before it can be accepted.

\section{1. macterization of Lithotypes}

In order to generate statistically meaningful results from the inversion of logging data, it is necessary to reduce the number of lithological components to as few endmember compositions as possible. A plot of x-ray diffraction data from whole-rock samples collected from Sites 800, 801 and 802 (Fig. 13; Behl, this volume) suggested the approach we used to characterize sediments drilled during Leg 129. For example, chert and chalk are obvious end members, composed primarily of silica and calcium carbonate, 
respectively. We have included a third possible end member, clay + zeolites, which allows the inclusion of radiolarite, porcellanite, and siliceous limestone in the system, as all three all fall between the three extremes on a temary diagram (Fig. 13). The same relationships roughly hold for the geophysical properties, with radiolarite, porcellanite, and siliceous limestone falling between the chert, chalk and clay + zeolite extremes.

With this scheme, radiolarite and porcellanite may be considered "clay-chert mixtures," both in terms of their geochemical composition and geophysical properties. Similarly, siliceous limestone could be called a "chalk-chert mixture," as these samples have velocities, densities, and silica and calcium carbonate contents falling between the two compositional extremes. We learned early on in this study that the inclusion of intermediate lithotypes introduces instability in the inversion of logging data. We started our analyses with 10 lithotypes, testing all possible combinations of seven or fewer for each logging depth, before settling finally on these five extreme lithotypes: chert, chalk, pelagic clay, clay/siltstone and sandstone/tuff.

These idealized lithotypes are assumed to have a narrow range of properties and compositions, and should not be confused with the more rigorously defined lithologies identified during Leg 129. For example, the lithotype "clay/siltstone" is used here to define a rock type that shares affinities with materials labeled as claystone and siltstone during the cruise. These materials have moderate velocities, densities, and silica contents, low calcium contents, and moderate-to-high aluminum, iron, and potassium contents. In fact, these materials are generally composed of a mixture of various amounts of clay (mainly illite, smectite, and mixed-layer), feldspar, quartz, zeolite, mica, and glass shards (Lancelot, Larson et al., 1990). Similarly, the "chalk" lithotype has been idealized to be dominantly calcium carbonate, with some silica and traces of other oxides. The "chert" lithotype is assumed to be mainly silica, with traces of other oxides plus the highest densities and velocities of all sedimentary materials through which logs were collected. 
The "pelagic clay" lithotype has the lowest velocity and density, plus relatively high silica, iron, aluminum and potassium contents. The most variable lithotype used for these inversions is "sandstone/tuff." The sandstone and tuff samples collected at all three sites display a wide range in properties, although the two lithologies have similar average values. Variations are as large within any one site as between sites. The lithotype is characterized by moderate-to-high concentrations of silica (largely as quartz grains in the sandstone and quartz plus glass shards in the tuff), aluminum, iron, and potassium and moderate densities and velocities. The differences between the two lithologies (sandstone at Sites 800 and 801 ; tuff at Site 802 ) are sufficiently significant, that the assumed compositions and properties were varied accordingly to improve the results of the inversions.

Tables 1 and 2 summarize the properties of the lithotypes allowed in all the models. The values used for the inversions originated from a variety of sources. Bulk density, sonic slowness, and (normalized) calcium oxide data were available from shipboard measurements, and appeared to match the logged data well in zones within which recovery was high. Other geochemical data were provided prior to publication by Karl and Karpoff (this volume), Behl (this volume), Karpoff (this volume), Karpoff et al. (this volume), and France-Lanord et al. (this volume). These values were normalized to be compatible with the five normalized oxides determined from the geochemical logs and used in this study. In addition, log data from isolated zones within which cores and logs suggested the presence of a single, dominant lithotype, were averaged to determine the expected log response. The final matrix values are a rough mix (really a compromise) of these different data sources.

\section{Whility of the Lithotype Model}

The selection of appropriate components requires that the lithotypes are (1) geologically reasonable and (2) statistically independent. As a test of independence, and of 
the of the ability of the seven chosen logs to discriminate among the lithotypes, we conducted a simple forward-modeling test. $\dot{A}$ lithologic column was created, with over 100 combinations of lithotypes; each component varied in abundance from 0 to $100 \%$ (by weight) of the total. Seven logs were then generated from this column (Fig. 14) and inverted. The resulting lithology column was then compared to the original column, yielding a standard error of $<1 \%$ in all cases (Fig. 15). This results shows that the lithotypes are independent and can be readily identified with the available logs. This test does not assure that the lithotypes are geologically reasonable, however, as this requires additional geological and geophysical evidence.

\section{Emor Analysis}

With seven log types and a maximum of five lithotypes, the system of equations inverted for this study is over-determined, allowing for detailed error analysis (e.g., Doveton, 1986). The most basic error analysis involves a comparison of recorded and calculated tool responses, with the latter based on the estimated lithologic percentages. After calculation of the proportions of the various lithotypes, the tool responses to the modeled system were calculated, based on the original relationships assumed between each lithotype and tool (Tables 1 and 2). In an exactly-determined system (the number of tools equals the number of lithologies minus one) this analysis would be useless. In an over-determined system, particularly one in which the different tool responses have been weighted, this analysis will provide a rough indication as to the numerical consistency of the model. It is still up to the geologist to evaluate the true "likeliness" of the modeled output.

Perhaps the most significant indicator is the negative sum error (NSE), the total of all proportions for which negative values were calculated during the inversion (Harvey et al., 1990). During the inversion of data from any one depth, negative proportions may be calculated if these values allow the best fit to the data. Geologically, negative proportions 
are impossible. The presence of large negative values following the inversion suggests that the assumed lithotypes and/or properties are inappropriate for the given data interval. Negative proportions may be calculated for several reasons. First, poor-quality data or incorrect depth-shifting between logs can result in a search for a "phantom" lithotype, with some combination of properties that is unrealistic. The same effect can result from having too few lithotypes. A model with too many poorly constrained lithotypes (intermediate types) can result in a matrix with singularities which never converge during inversion (effectively forming an error-space that is too "shallowly dished" for a minimum to be found).

Our program deals with negative proportions in several ways. First, the component that is most negative is eliminated, and the inversion is repeated with one fewer acceptable lithotype. The elimination is continued, if necessary, until a minimum of two lithotypes remains. If there is still a high NSE (arbitrarily chosen to be decimal fraction 0.20 , or $20 \%)$, then the solution with the smallest NSE is accepted. Negative proportions are then set equal to zero and the remaining proportions are normalized to add to $100 \%$.

Another useful error indicator is the standard error of the forward-modeled logs, expressed as a percentage of the total original signal, which shows how well the final lithology column simulates the field data. We have designed our inversion program to correct the physical properties of clay-rich lithotypes as a function of depth, based of the property-depth rebound relationships defined previously (Figs. 2 and 3). This requires that the matrix of typical lithologic characteristics be inverted at every log-measurement depth of interest, but the computational price for this extra number crunching is small.

A more significant problem with log inversion which is not typically discussed (e.g., Doveton, 1986; Jarrard et al., 1989; Harvey et al., 1990) involves the numerical technique used to invert the log-lithology matrix. If the original matrix is simply inverted algebraically, with no regard to either machine precision or pivot size, enormous errors 
can be introduced (Camahan et al., 1969). This problem is compounded when the typical values found in the original matrix vary in size by 2 or more orders of magnitude (e.g., with sonic slowness in units of $\mathrm{ms} / \mathrm{ft}$, values of $80-200$ are common, while with potassium oxide content in weight percent, values near zero are common). The resulting difference in magnitude will cause a single-precision computing device to introduce large rounding errors. We ran all analyses using double-precision storage and used IMSL subroutines that optimized matrix parameters to reduce numerical imprecision and provide warning flags for small pivot operations.

The greatest uncertainly in this study probably originates from the primary underlying assumption: all significant lithotypes present within the intervals logged during Leg 129 are directly or indirectly represented by the five possible lithotypes defined earlier. This assumption requires that all significant lithologies within the section at any one site are represented in the cores recovered during the cruise.

\section{Nhotype Inversions from Sites 800,801 . and 802}

Figure 16 graphically illustrates the modeled lithotypes determined with the inversion procedure described previously for the logged interval (50 to $275 \mathrm{mbsf}$ ) in Hole $800 \mathrm{~A}$, with all quantities reported in weight percent. Pelagic clay content is generally greater than 20\%, and is highest overall within lithologic Units II and IV. The proportion of chert is $30 \%$ to $40 \%$ through most of Units II and III, although the abundance of this lithotype drops to near zero between 130 and 140 mbsf within Unit III. This depth corresponds to a predicted peak in the chalk lithotype, which was relatively rare in the cores recovered from this section of Hole $800 \mathrm{~A}$. The predicted high chalk content at $80-$ 140 mbsf reflects relatively high calcium content and low velocities. The actual lithology sandwiched between thin chert beds at Site 800 could also be a clay-rich, calcium carbonate ooze; it is certainly soft and calcium rich. The 160-190 mbsf interval includes both high predicted chalk $(>30 \%)$ and high predicted chert $(>25 \%)$ lithotypes and may 
actually be composed largely of siliceous limestone, rather than a chalk/chert mixture. Recovery was poor throughout this interval, but included a significant proportion of siliceous limestone (Shipboard Scientific Party, 1990a).

The sandstone lithotype makes a first significant appearance near 220 mbsf, somewhat higher than the top of lithologic Unit IV (Fig. 16). The dominant lithotypes predicted below this depth (sandstone, clay/siltstone, pelagic clay) are the main components that form volcaniclastic turbidites, which characterize this unit. One interesting exception is the zone between 260 and $270 \mathrm{mbsf}$, which is predicted to contain a significant chert component, coinciding with the first significant return of porcellanite in the recovered core. It seems geologically unlikely that actual pelagic clay, as cored in lithologic Unit I, is present within the Cretaceous volcaniclastic turbidites of lithologic Unit IV, but the predicted presence of this lithotype reflects the relatively low velocities, low calcium content, and high aluminum content of this part of the logged interval. Removing pelagic clay from the list of possible lithotypes greatly increases the NSE of the inversion because negative proportions of other lithotypes are required to account for the observed low velocity and low calcium content of several intervals. The standard error of the inversion at Site 800 is very low, and the NSE averages about 0.1 , although some zones have values above $\mathbf{0 . 2}$.

The inversion at Site 801 yielded a quantitatively poorer estimate of the primary lithotypes present throughout the logged interval ( $80-440$ mbsf; Fig. 17). The standard error of the fit is higher overall than at Site 800 (although still generally less than 5\%), whereas the negative sum of the errors reveals several thin zones with a poor fit. Chert appears to comprise about $40 \%$ of the lower part of lithologic Unit II, and then appears in two parts of Unit III, $180-200$ and $280-300$ mbsf, both intervals of extremely poor recovery (Shipboard Scientific Party, 1990b). The sandstone lithotype is predicted mainly within the boundaries of lithologic Unit III, composing as much as $80 \%$ of the total rock 
mass, whereas chalk is absent throughout most of the logged interval. A large increase in the predicted chert content corresponds to the top of lithologic Unit IV, and is clearly consistent with the appearance of radiolarite, porcellanite, and chert in the cores. Material not recovered throughout this interval of Hole $801 \mathrm{~B}$ could well be more radiolarite (rather than some softer material such as pelagic clay) as the idealized lithotypes of chert and pelagic clay could be combined.

The inversion of logs for lithologies was least effective at Site 802 (Fig. 18), which is surprising at first, considering the good match of the laboratory and log physicalproperties data. The standard error of the fit is significantly higher than at Sites 800 and 801 , and the negative sum of the errors averages about 0.20 . More troubling, there are many sections of the hole within which the NSE exceeds 0.5 , and a few where it is greater than 1.0. Very high NSE values suggest either that the logs are bad over the interval in question, or that the assumed lithotypes and characteristics used in the inversion are inappropriate. The latter could easily result because (1) there is at least one major lithotype That has been left out (the set is incomplete), (2) one or more of the assumed lithotypes has been assigned incorrect average parameters, and/or (3) there is such extreme variation in properties such that inversion for lithology is impossible at this depth. We attempted to improve the model of Hole 802A with different combinations of four and three possible lithotypes and by altering the expected compositions of the lithotypes, but the quality of the fit did not improve appreciably. It is revealing that several parts of the logged interval at Site 802 include unrealistically low silica and high iron contents (Fig. 12), perhaps due to a problem in calibration of the logging tool or in basic processing. One could accommodate this kind of problem by reducing the weight applied to the silica and iron signals, but this would result in an effectively underdetermined system, as these data are needed to discriminate between several lithotypes.

Despite the poor fit over parts of the logged interval, the modeled output may 
predict reasonable trends within several zones. A large increase in predicted chalk content (from essentially zero to 30-40\%) takes place near the boundary between lithologic units II and III, while the predicted proportion of sandstone drops dramatically. The candstone/pelagic clay ratio within Unit II appears to drop off with depth, as was observed in the cores (Shipboard Scientific Party, 1990c). The model also predicts several significant, isolated accumulations of chert within Unit III (Fig. 18). The corrected laboratory porosities from Hole 802A match well with the synthetic log porosities (which are based on the borehole lithodensity log and a mean grain density determined for each depth from the inversion described above) indicating that the physical properties data set is self consistent, as are the general trends in the inverted lithology columns (Fig. 7A).

\section{DISCUSSION AND SUMMARY}

A wide variety of lithologies was cored and recovered during ODP Leg 129, although statistical representation of the drilled section is probably poor. Several of the cored lithologies are easily distinguished on the basis of consistent physical and chemical parameters, whereas others are better classified as mixtures of more extreme end members. Of the lithologies represented in cores, only those rich in clay appear to require significant rebound corrections. A closed set of lithotypes was defined, based on the variety of sediment types observed during Leg 129, and a combined set of logs was inverted to determine the relative proportions of each lithotype present throughout the logged interval.

The subjective "quality" of these inversions, as indicated by the NSE values, appears to correlate well with the size of the "normalization factors" used by Pratson et al. (this volume, their Figs. 4,6 and 8) to invert the original geochemical logging data to generate oxide estimates. These authors suggest that the size of the normalization factor (NF) reflects the quality of the "counting statistics" (with a lower NF reflecting better 
data), but a large NF could also indicate errors in instrument calibration, depth shifting, or data processing. More significantly, the good correlation between the large NF and large NSE values suggests that at least part of the inaccuracy associated with the analysis presented here was introduced prior to the classification of lithotypes and subsequent inversion.

The inversion of data from Hole $802 \mathrm{~A}$ may reveal the greatest limitation of this method, that it requires some a priori knowledge of the composition (or at least the closed set of possible compositions) of the various lithologies within each interval of the logged hole. The forms of error analysis available for checking lithologic inversions are most rigorous in terms of numerical consistency, but do not directly address problems related to missing or incorrectly characterized lithotypes. A variety of optimization schemes could be employed to improve the fit by modifying the chemistry or properties of the acceptable lithotypes (within a range constrained by laboratory data) but there is no way to test directly the validity of the resulting inversion. We attempted an optimization scheme in which the number of acceptable lithologies was varied to find the best statistical fit to the log data, but found that the solutions were often unstable, with no quantitatively reliable means for choosing one model over another. Instead, it probably makes the most sense to look at general trends in the modeled output and interpret the logged interval accordingly.

The inversion of data from Site 800 suggests that pelagic clay comprises the missing lithology within Unit II, whereas chalk and pelagic clay lithotypes (as defined in this paper), or perhaps chalky radiolarite, porcellanite, or some combination of the preceding, comprises the missing material within Unit III. It is unlikely that more than about $30 \%$ of this missing material is actually chert or siliceous limestone, as the densities and velocities of these lithologies (Fig. 8) are too high in comparison to the log and interval means (Fig. 9).

In contrast, there is probably little chalk and significantly more clay and claystone 
within the logged units at Site 801. The turbidites of Unit III appear to be coarser overall than those of the upper part of Unit IV at Site 801, based on the modeled sandstone and clay/siltstone lithotypes. Two significant "cherty" intervals have been identified within lithologic Unit III at Site 801 (possibly radiolarite, porcellanite, or true chert) and one such interval within the upper portion of Unit IV at Site 800. The composition of lithologic Unit IV at Site 801 appears to be relatively uniform, with approximately equal components of chert and pelagic clay lithotypes, and about half again as much clay/siltstone. In this interval, it appears that the recovered material is a better statistical sample than that of the overlying units.

This inversion procedure is useful where recovery is extremely low, but probably has greater utility when all the possible lithologies within a section are better characterized. This characterization might take place during drilling of a nearby borehole, or could result from core taken while drilling the hole in question if recovery is sufficiently high (perhaps 40\%-60\%). In the latter case the lithotypes could be well defined, but there may still be a need to establish accurate estimates of the overall proportions of each lithologic component.

\section{ACKNOWLEDGMENT}

Thanks to R. Behl, C. France-Lanord, S. Karl, A. Karpoff, and J. Ogg for providing sediment composition data prior to publication. Special thanks to the staff of the Borehole Research Group, and to Beth Pratson in particular, for their patience and assistance. Reviews by R. Wilkens and W. Bruckmann were also appreciated. This work was partially supported by PRF grant 23615-G2, by the Ocean Drilling Program, and by USSAC grants 20408 (ATF), 20431 (LA), and 20425 (WHB). 
TABLES AND FIGURES 
Table 1. Assumed properties and compositions of lithotypes used at Sites 800 and 801.

Table 2. Assumed properties and compositions of lithotypes used at Site 802. 


\begin{tabular}{|c|c|c|c|c|c|c|c|}
\hline Lithotype & $\rho_{b}$ & $1 / v$ & $\mathrm{SiO}_{2}$ & $\mathrm{Al}_{2} \mathrm{O}_{3}$ & $\mathrm{FeO} *$ & $\mathrm{CaO}$ & $\mathrm{K}_{2} \mathrm{O}$ \\
\hline & $\left(\mathrm{g} / \mathrm{cm}^{3}\right)$ & $(\mu s / f t)$ & (wt\%) & (wt\%) & $(w t \%)$ & (wt\%) & (wt\%) \\
\hline Pelagic clay & 1.38 & 200 & 68.9 & 16.4 & 6.7 & 3.9 & 2.3 \\
\hline Clay/siltstone & 1.84 & 158 & 66.2 & 8.9 & 11.0 & 7.4 & 1.3 \\
\hline Chert & 2.52 & 62 & 95.4 & 2.0 & 1.5 & 4.0 & 0.5 \\
\hline Chalk & 2.00 & 142 & 8.0 & 1.5 & 1.0 & 89.0 & 0.5 \\
\hline Tuff & 1.85 & 111 & 65.0 & 13.6 & 15.0 & 7.1 & 1.3 \\
\hline Weight & 1.0 & 1.0 & 0.8 & $0 . \dot{6}$ & 0.6 & 1.0 & 0.6 \\
\hline
\end{tabular}

Note: The selection and characterization of lithotypes is discussed in the text. Oxide contents are based on normalized geochemical data from Shipboard Scientific Party (1990c), Behl et al. (this volume), Karl et al. (this volume), and Karpoff et al. (this volume), and from selection of single-lithotype intervals from the logs.

-Weights are subjective, and are based on the assumed accuracy of the individual logs plus the importance placed on each log in terms of its ability to discriminate lithotypes. 


\begin{tabular}{|c|c|c|c|c|c|c|c|c|}
\hline \multirow[t]{2}{*}{ Lithotype } & $\begin{array}{c}\rho_{\mathrm{b}} \\
\left(\mathrm{g} / \mathrm{cm}^{3}\right)\end{array}$ & $\begin{array}{c}1 / v \\
(\mu s / f t)\end{array}$ & $\begin{array}{l}\mathrm{SiO}_{2} \\
(w+\%)\end{array}$ & $\begin{array}{l}\mathrm{Al}_{2} \mathrm{O}_{3} \\
(w t \%)\end{array}$ & $\begin{array}{l}\mathrm{FeO} \\
(w+\%)\end{array}$ & $\begin{array}{c}\mathrm{CaO} \\
(w t \%)\end{array}$ & $\begin{array}{l}\mathrm{K}_{2} \mathrm{O} \\
(\mathrm{wt} \% \text { ) }\end{array}$ & \\
\hline & & & . & & & & & \\
\hline Pelagic clay & 1.38 & 200 & 73.0 & 13.4 & 4.7 & 3.9 & 2.3 & \\
\hline Clay/siltstone & 1.84 & 158 & 71.2 & 5.9 & 9.0 & 7.4 & 1.3 & \\
\hline Chert & 2.52 & 62 & 95.4 & 2.0 & 1.5 & 4.0 & 0.5 & \\
\hline Chalk & 2.00 & 142 & 18.0 & 1.5 & 1.0 & 79.0 & 0.5 & \\
\hline Sandstone & 1.90 & 118 & 80.0 & 10.6 & 9.0 & 0.1 & 1.2 & \\
\hline -Weight & 1.0 & 1.0 & 0.8 & 0.6 & 0.6 & 1.0 & 0.6 & \\
\hline
\end{tabular}

Note: The selection and characterization of lithotypes is discussed in the text. Oxide contents are based on normalized geochemical data from Shipboard Scientific Party (1990a,b), Behl et al. (this volume), Karl et al. (this volume), and Karpoff et al. (this volume), and from selection of single-lithotype intervals from the logs.

- Weights are subjective, and are based on the assumed accuracy of the individual logs plus the importance placed on each log in terms of its ability to discriminate lithotypes. 
Figure 1. Locations of ODP Sites 800,801 , and 802 in the western Pacific (Lancelot, Larson, et al., 1990). 


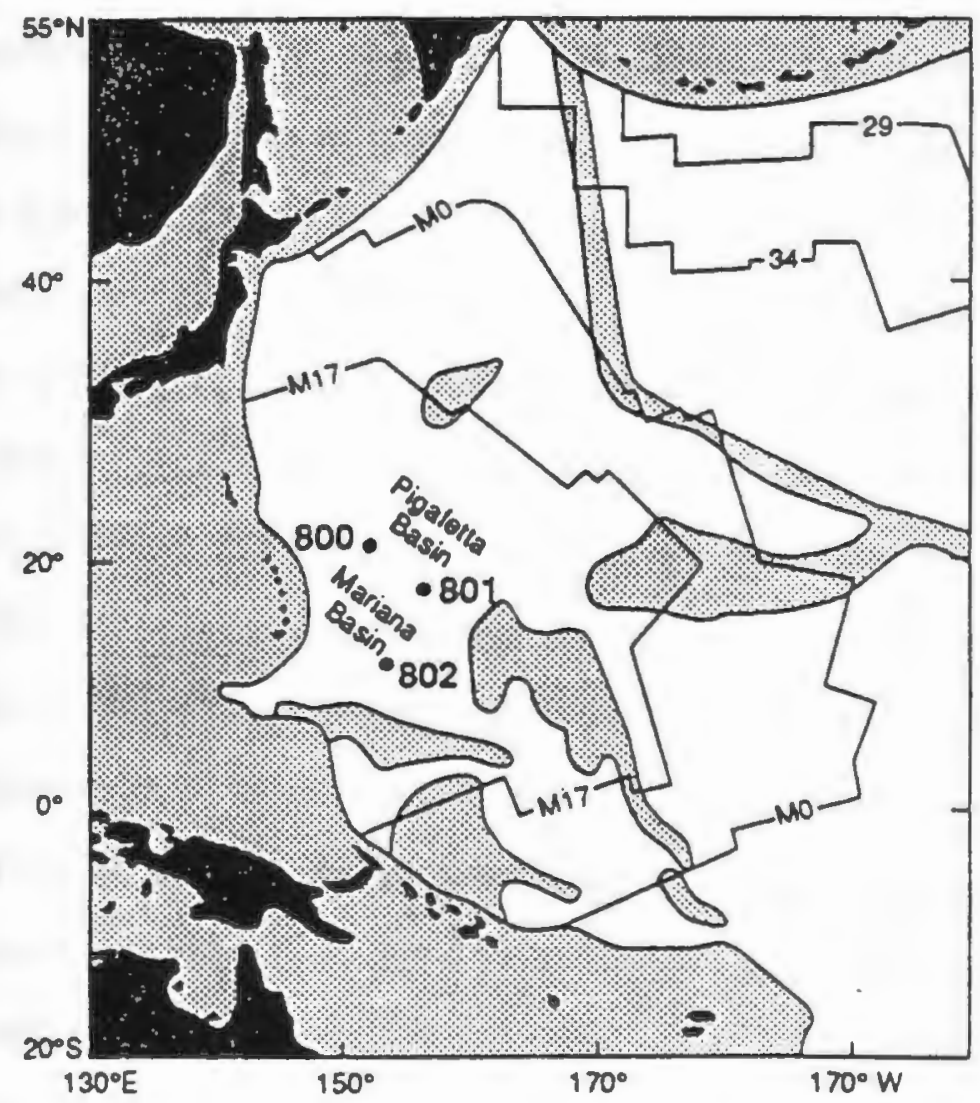


Figure 2. Uncorrected porosity vs. depth for all physical-properties samples collected during Leg 129. Sediment assignments are based on observations by shipboard scientists (Lancelot, Larson, et al., 1990) A. Solid squares: claystone and pelagic clay; solid circles: siltstone; solid triangles: sandstone. The dotted curves on the right side of the figure were determined by Hamilton (1976) for "typical" pelagic clay $(\mathrm{P})$ and terrigenous clay $(\mathrm{T})$ and are second-order polynomials. The best-fit solid curve that passes through data from the Leg 129 pelagic clay and claystone samples falls between the two Hamilton curves, suggesting that these sediments follow similar compactional trends. Best-fit curves for the siltstone samples (long dashes) and sandstone samples (short dashes) show much smaller compactional trends. The solid curves on the left side of the figure illustrate Hamilton's (1976) rebound corrections for pelagic clay (P) and terrigenous clay (T). All Leg 129 clay samples were rebound-corrected using the more conservative, terrigenous correction. B. The remaining sediment types characterized by porosity measurements during Leg 129 reveal no consistent compactional trends, suggesting that rebound corrections are unnecessary. Open squares: chert; open circles: chalk; open diamonds: siliceous limestone, open triangles: porcellanite; pluses: radiolarite; x's: tuff. 
Porosity (\%)

Porosity (\%)

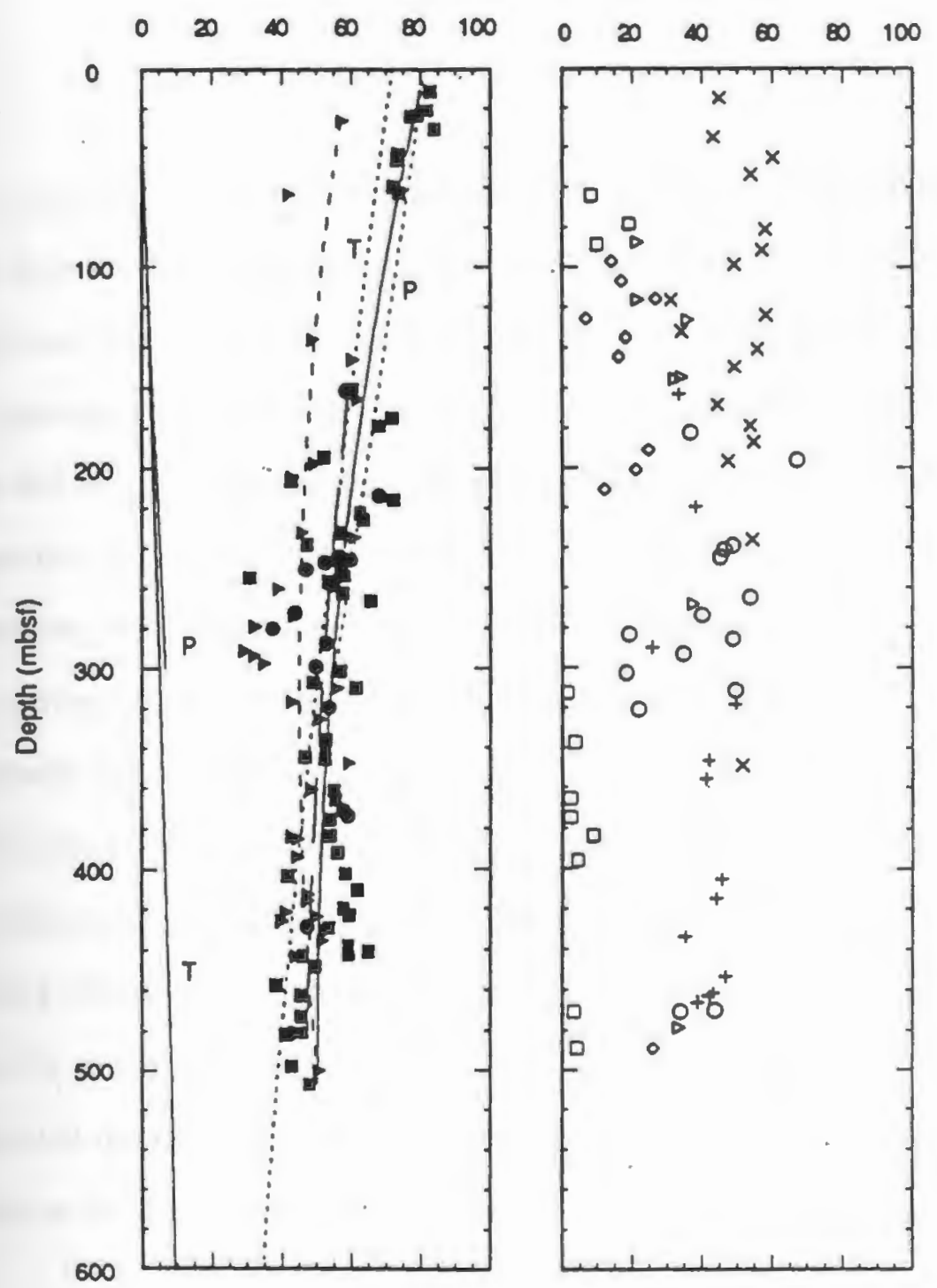


Figure 3. Cross-plots of the physical properties of pelagic clay and claystone samples. The best-fit curves in these figures were used to apply rebound corrections to shipboard data. A. Vertical compressional-wave velocity vs. porosity. Circles are laboratory data from all sites; squares are log data within clay-rich zones from Site 800 only. The presence of intervals composed mainly of clay was not apparent from the logs at Sites 801 and 802. Log velocities were measured directly, but log porosities were determined from the lithodensity log and a synthetic grain density log derived from the lithologic inversion described elsewhere in this paper. The borehole and laboratory trends agree. The solid line is a best-fit, second-order polynomial through the laboratory data only. B. Bulk density vs. porosity. Circles are measurements made using standard gravimetric methods; squares are from twominute GRAPE measurements (Lancelot, Larson et al., 1990). The solid line is a best-fit, second-order polynomial through all data (A). The dashed line is the expected relationship from trends listed in Hamilton (1976) for pelagic clay (P), whereas the dotted line is a similar relationship for terrigenous clay (T). 

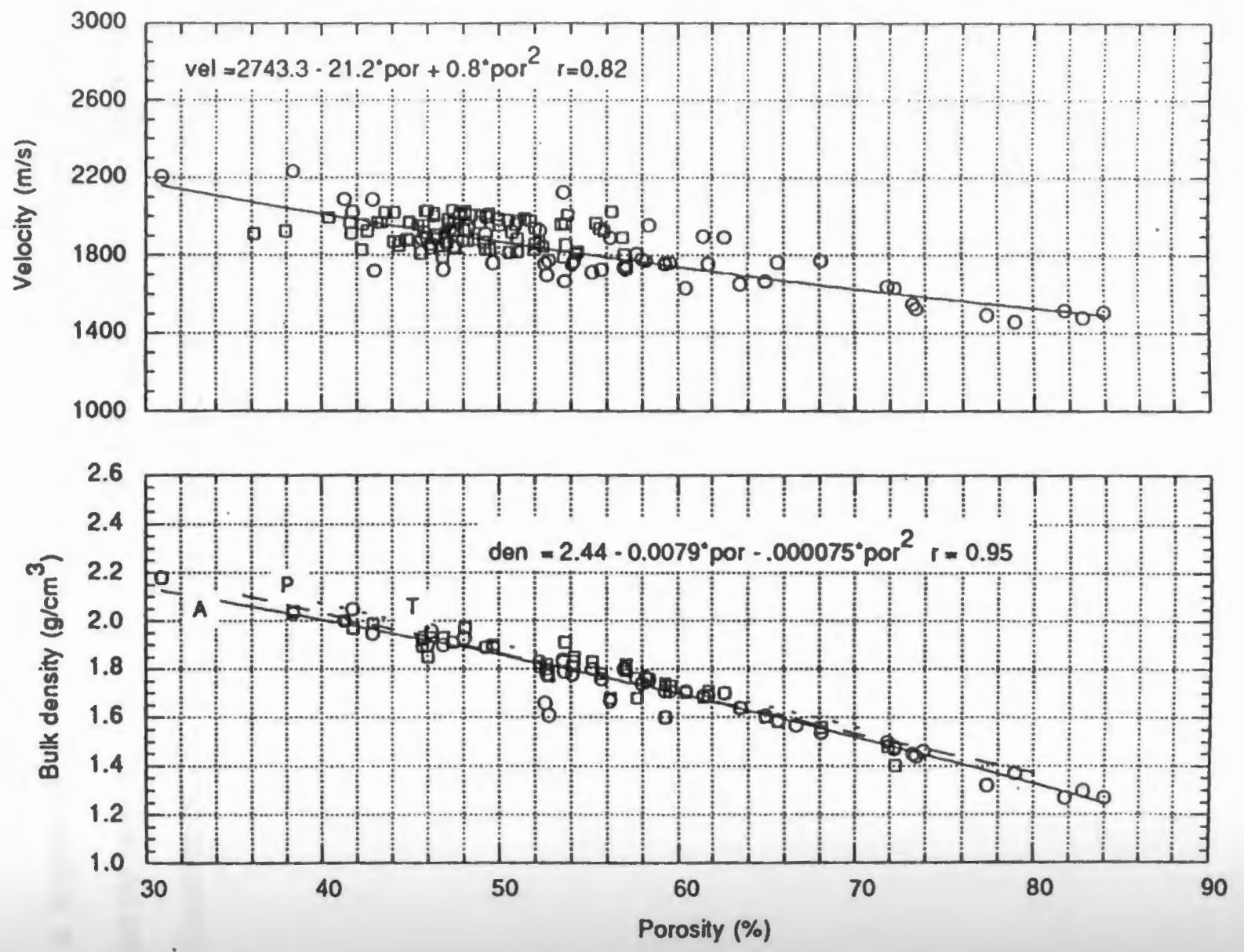
Figure 4. Rebound-corrected physical properties vs. depth from Leg 129 . The symbols are the same as in Figure 2. The solid lines illustrate trends in the pelagic clay and claystone data. A. Bulk density. B. Compressional-wave velocity. 


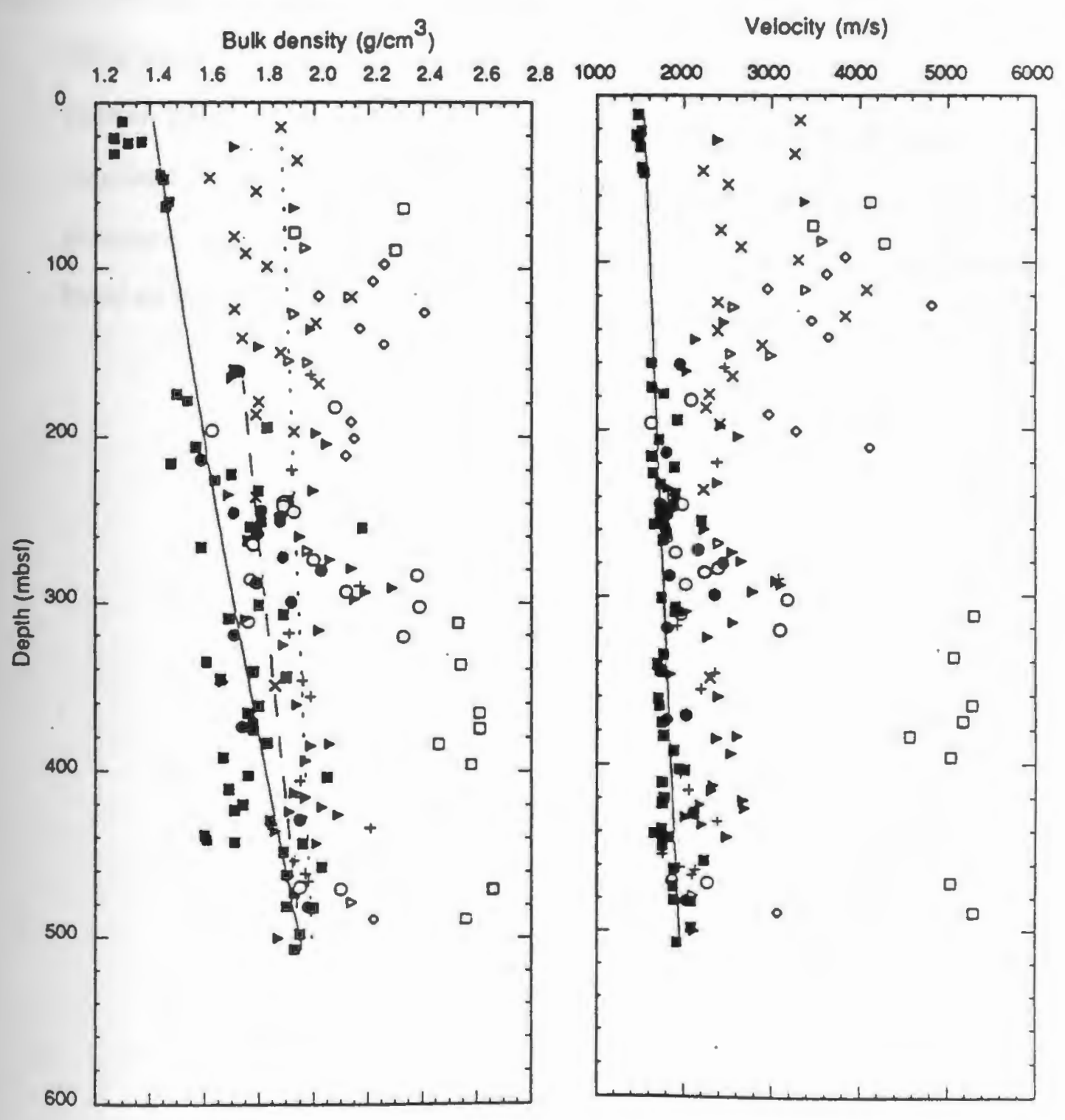


Figure 5. Physical properties from shipboard (symbols and dashed lines) and log (solid lines) measurements from Site 800. Log data have been smoothed using a 0.5-m boxcar filter. Shipboard measurements of clay samples have been rebound corrected. No porosity logs were run during Leg 129; a synthetic porosity log was generated using the lithodensity log and an average grain density for each depth based on the lithologic inversion presented later in this paper. 


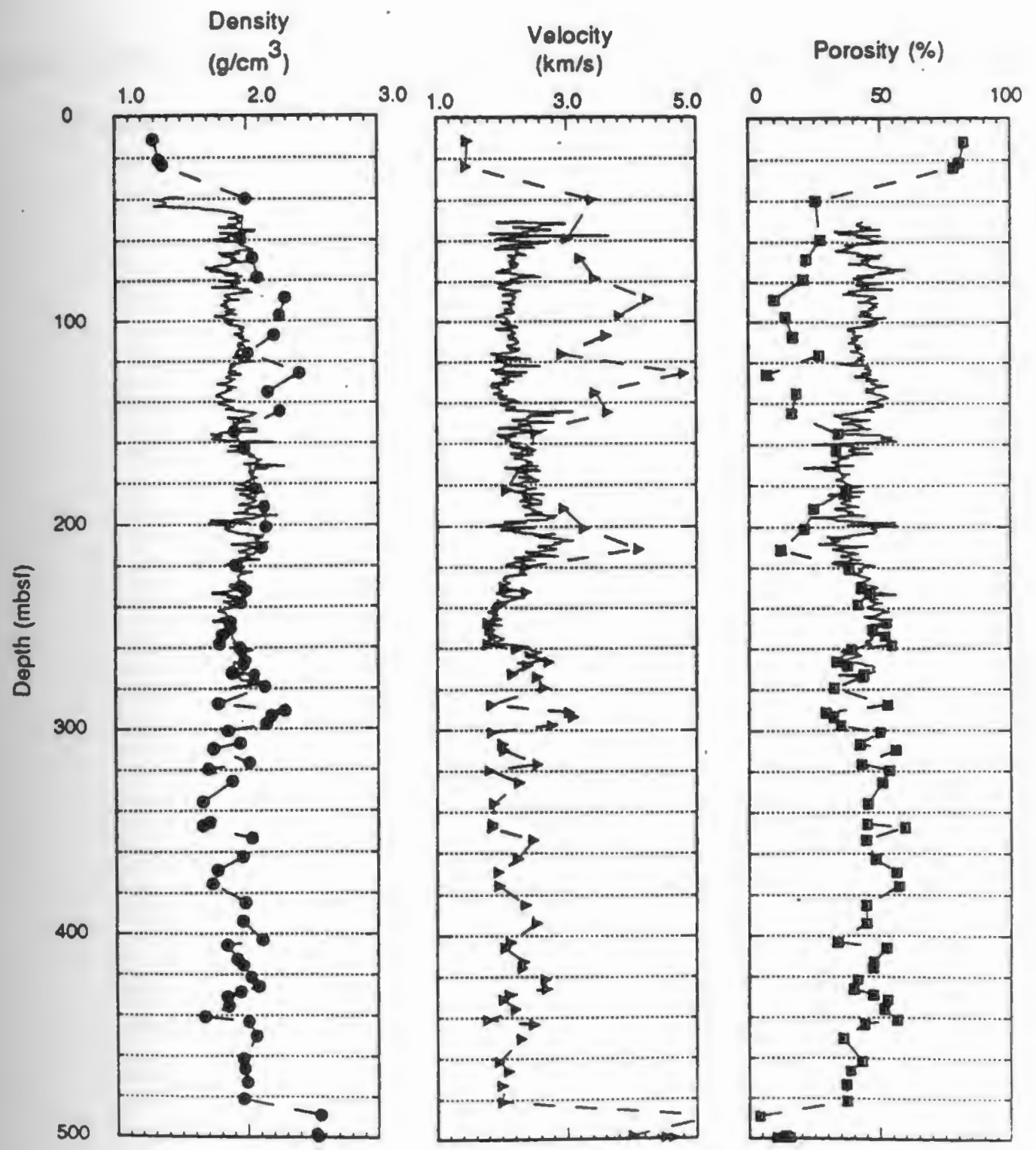


Figure 6. Physical properties from shipboard (symbols and dashed lines) and log (solid lines) measurements from Site 801; curves and symbols are as in Figure 5. 

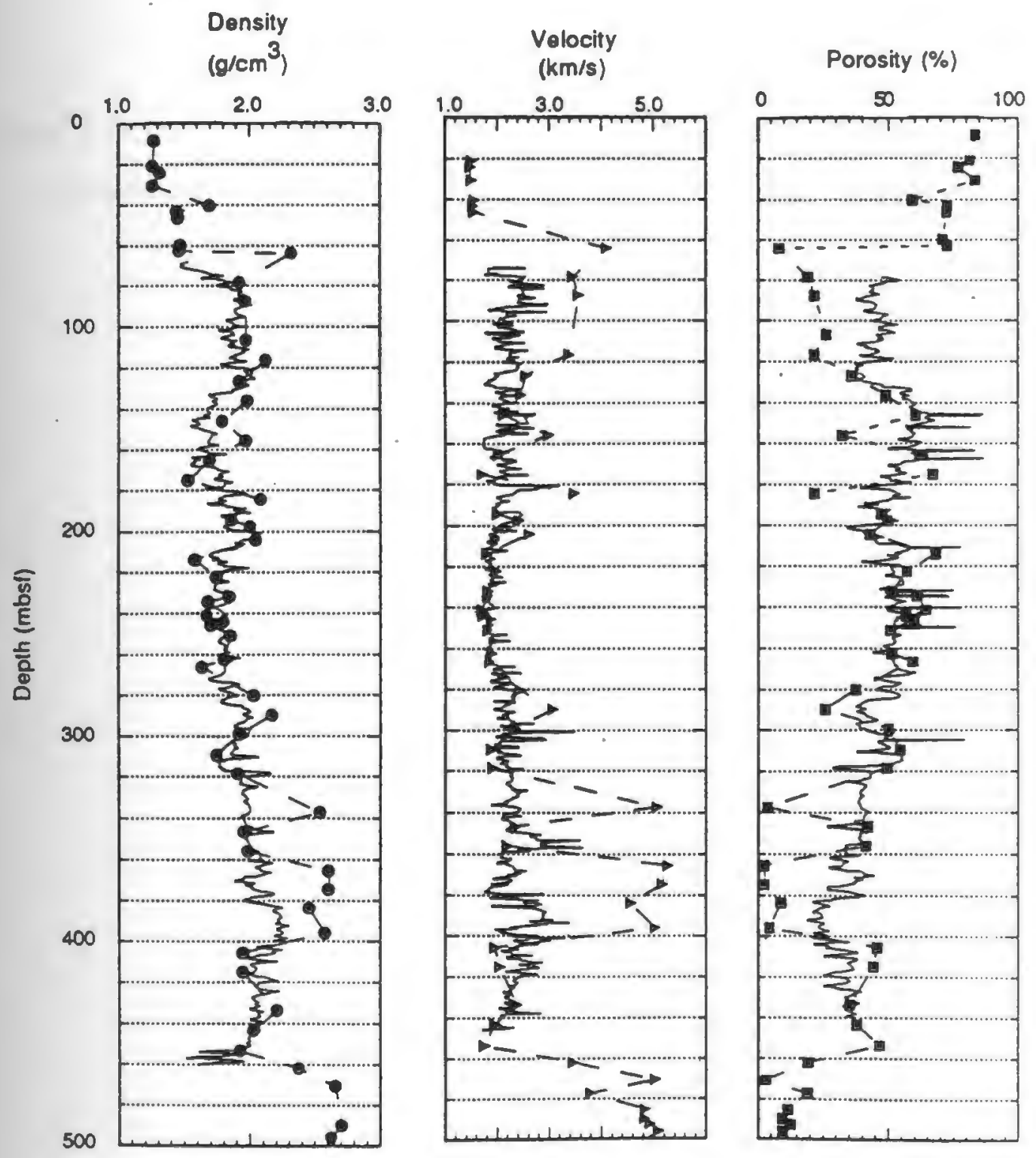
Figure 7. Physical properties from shipboard (symbols and dashed lines) and log (solid lines) measurements from Site 802; curves and symbols are as in Figure 5. 

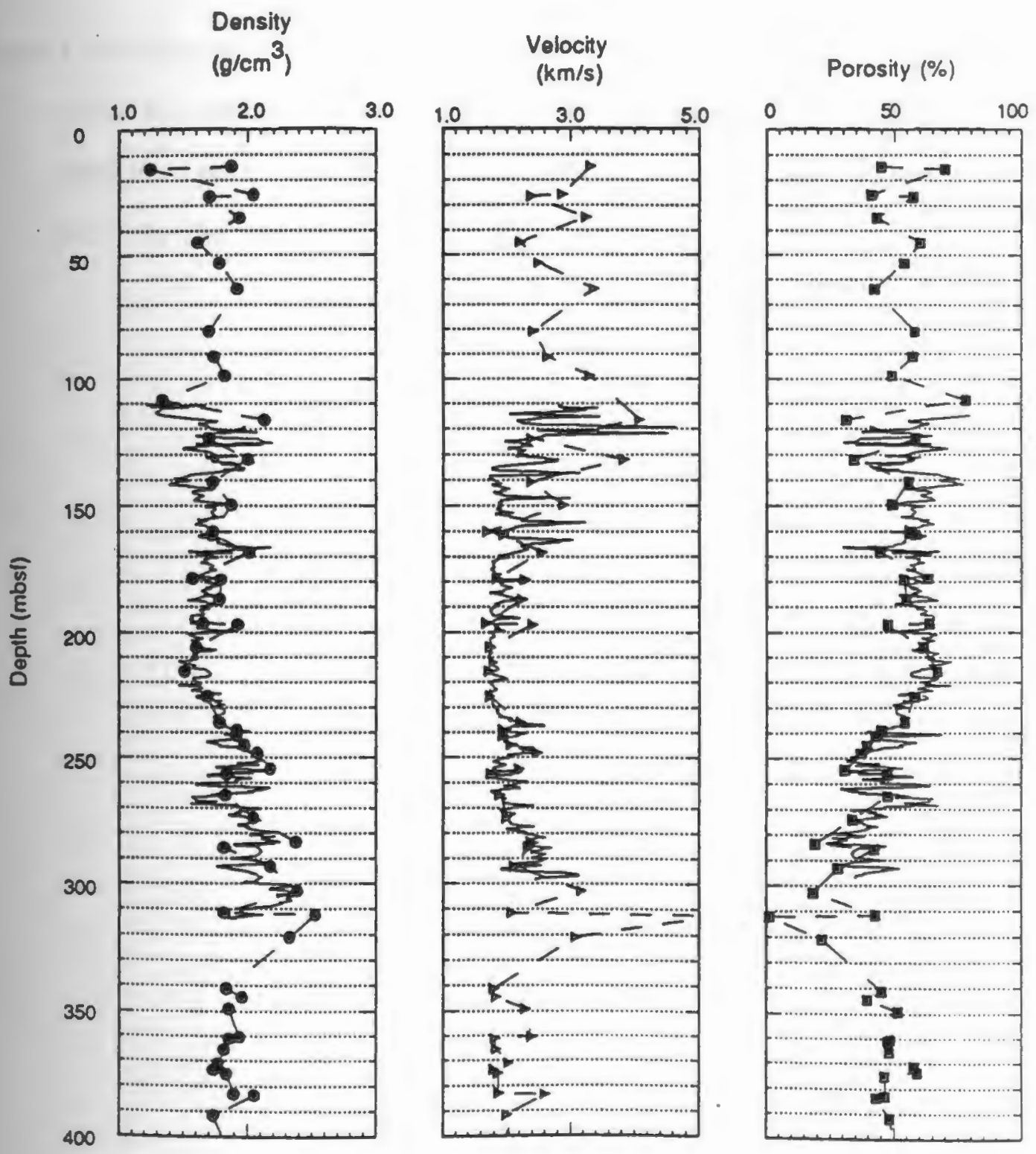
Figure 8. Average bulk density, vertical compressional-wave velocity, and grain density values for each of the 10 primary lithologies identified during Leg 129, as determined with shipboard measurements. Bars indicate one standard deviation. Data from clay samples have been rebound corrected. 


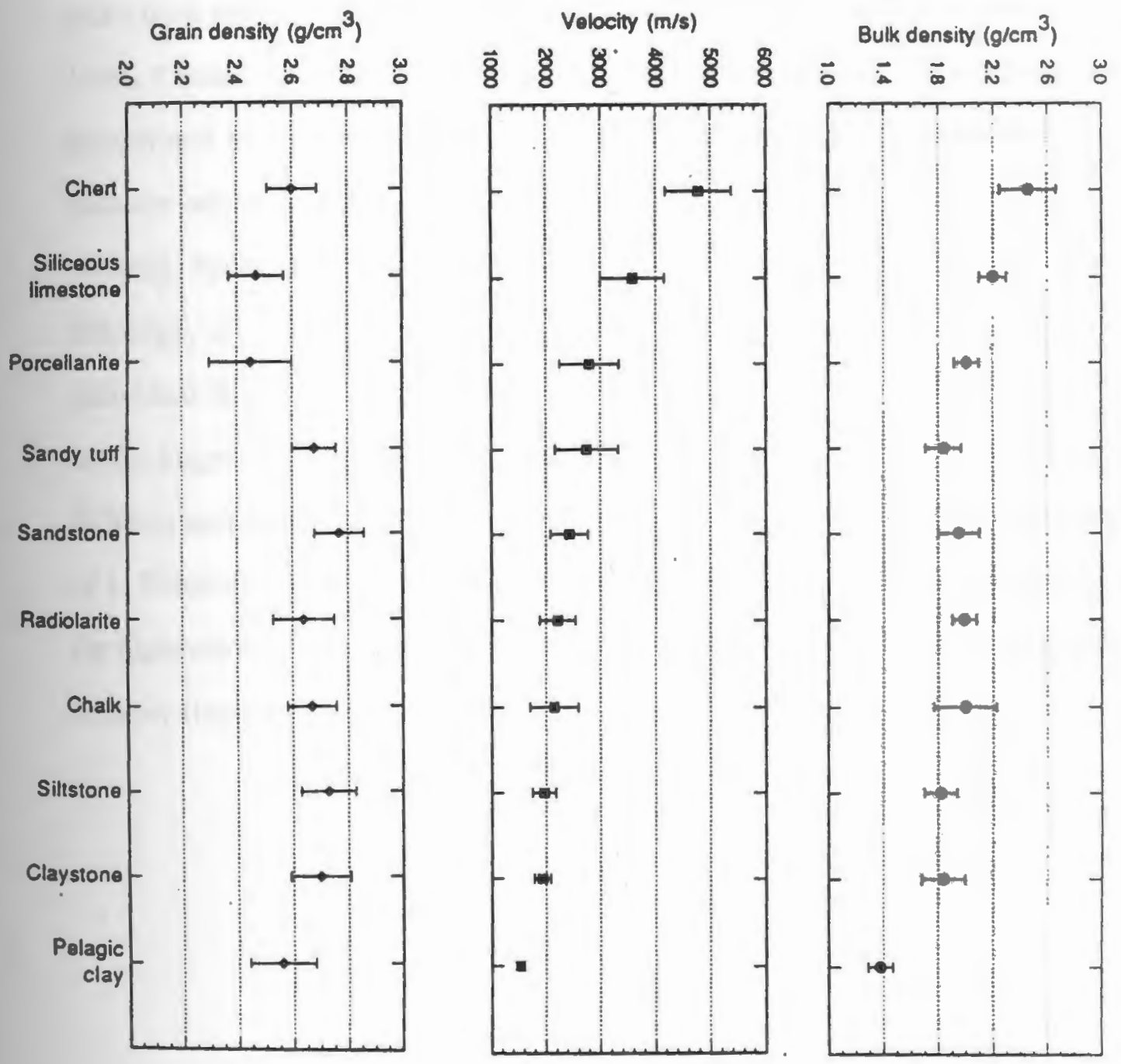


Figure 9. Sonic slowness for individual logged intervals vs. interval slowness, based on picks from synthetic seismograms made during Leg 129 (Lancelot, Larson, et al., 1990). Circles: Site 800; squares: Site 801; triangles: Site 802. Sonic slowness was determined by averaging measurements from the long-spaced sonic tool; bars indicate one standard deviation. Slowness was used in this study, rather than velocity, because the former is believed to vary more linearly as a function of lithology, as discussed in the text. Solid symbols indicate the slowness of individual intervals, whereas the large, open symbols indicate average values for entire logged sections. A good match between determinations made with the different methods would result in points that fall on the solid line, which has a slope of 1. Relative to sonic-log determinations, interval picks overestimated velocities for high-velocity (low-slowness) materials and underestimated velocities for lowvelocity (high-slowness) materials. 


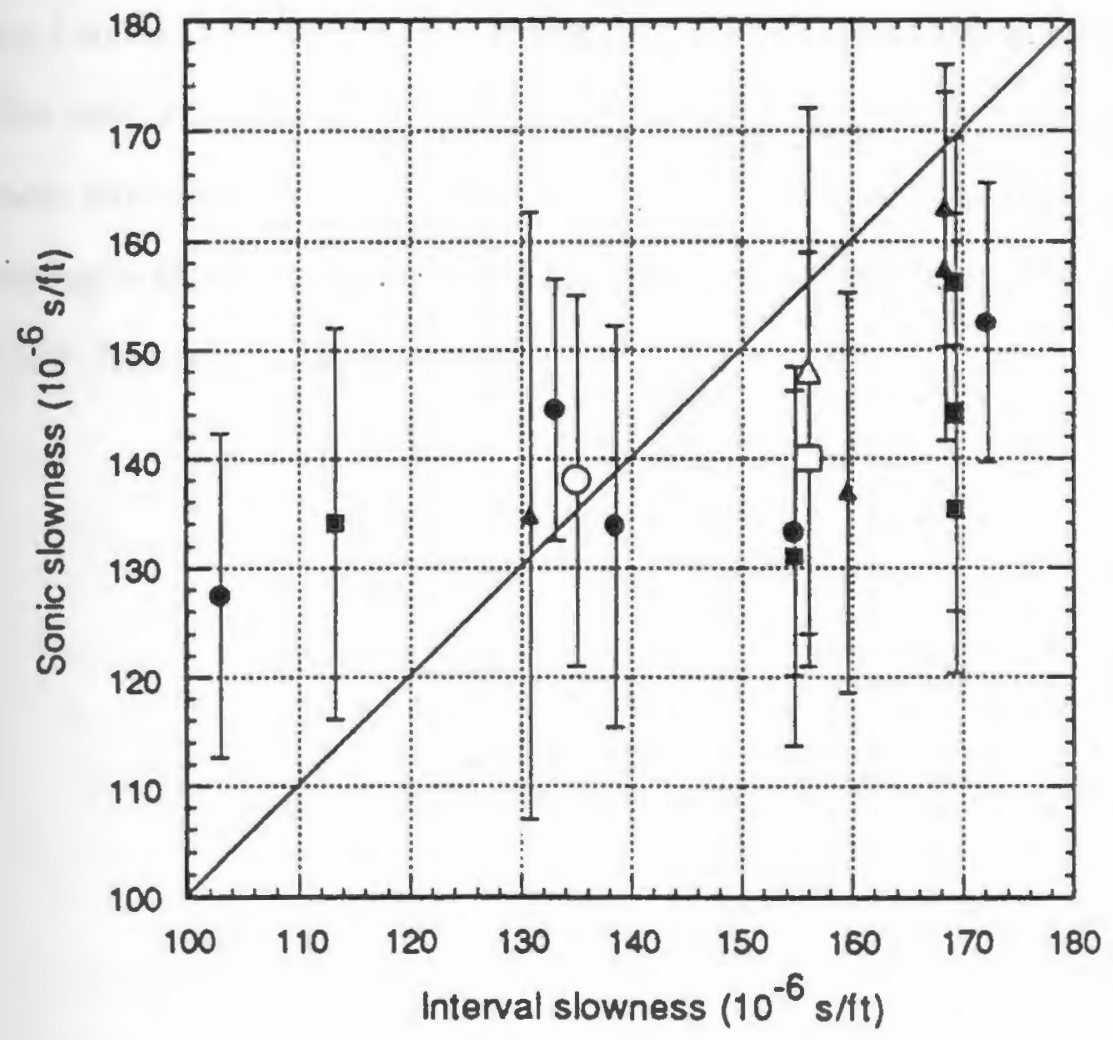


Figure 10. Normalized oxide contents of Site 800 sediments, from logs and laboratory determinations. Laboratory data are from Karl and Karpoff (this volume): circles; France-Lanord et al. (this volume): diamonds; Karpoff (this volume) and Karpoff et al. (this volume): squares; and Shipboard Scientific Party (1990a): triangles. The borehole data have been smoothed with a $0.5-\mathrm{m}$ boxcar filter. Geochemical log processing is described briefly in the text and in more detail elsewhere (Hertzog et al., 1989; Pratson et al., this volume). 


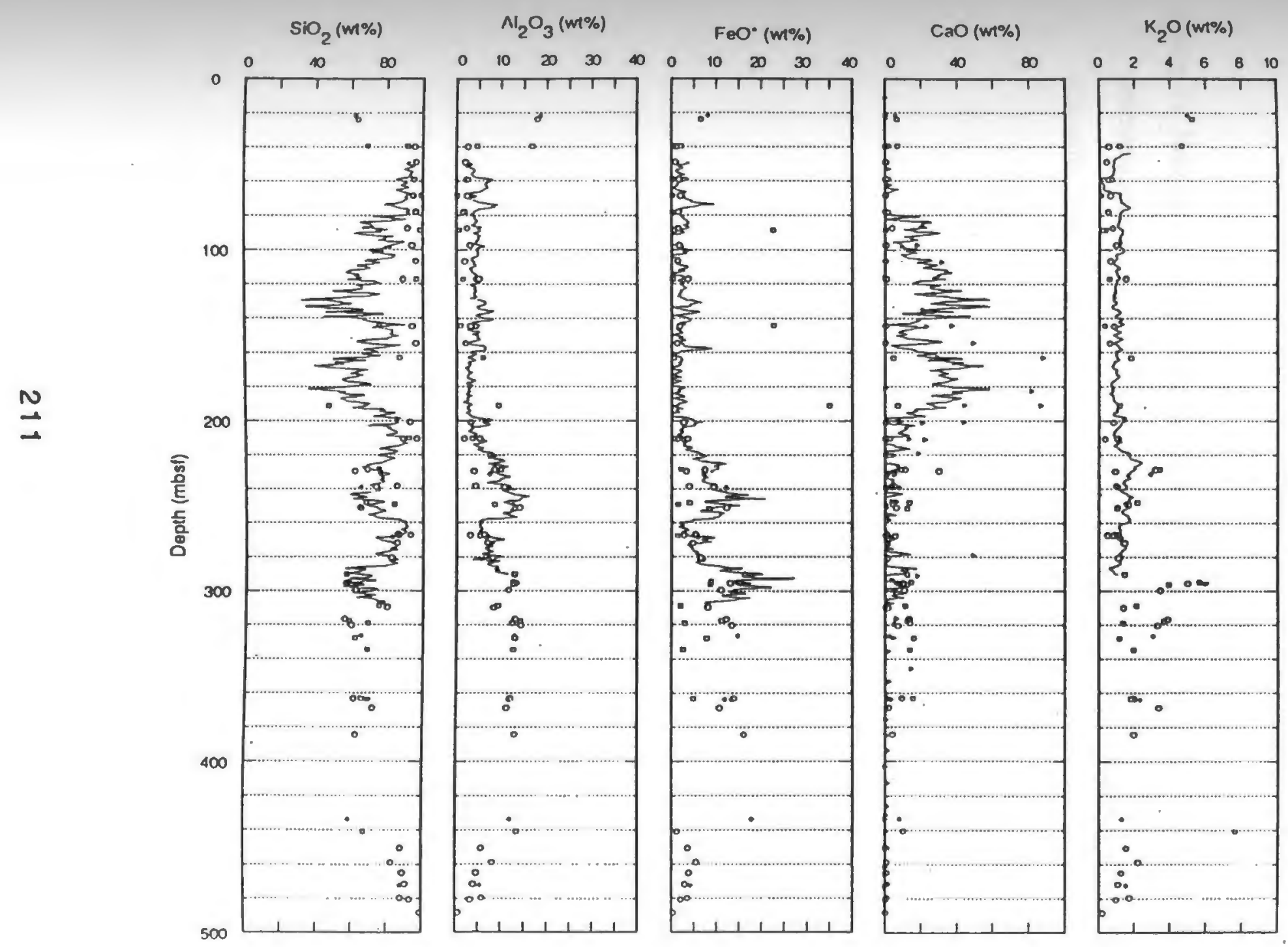


Figure 11. Normalized oxide contents of Site 801 sediments, from logs and laboratory determinations. Symbols are as in Figure 10, but with data from Shipboard Scientific Party (1990b). 

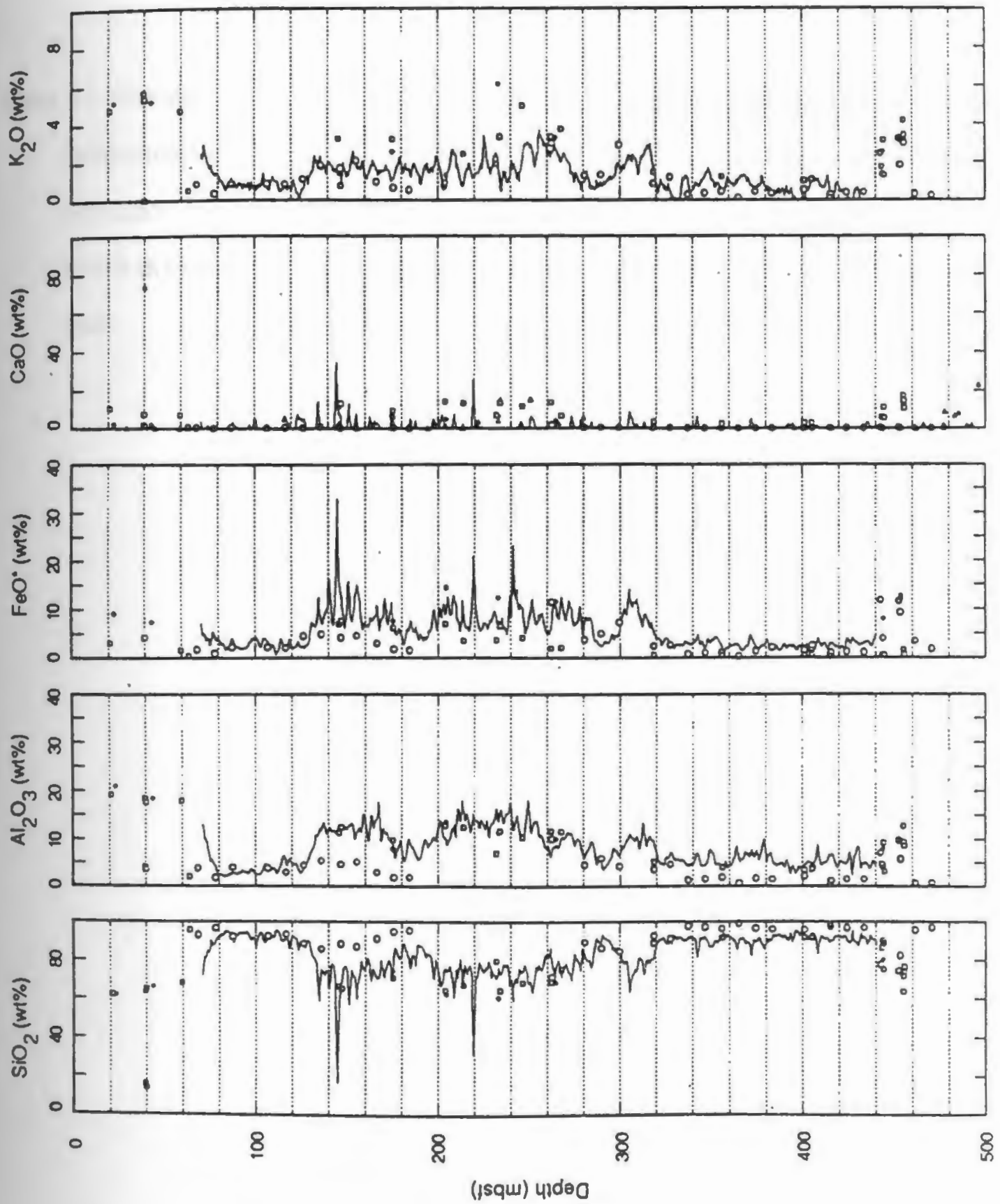
Figure 12. Normalized oxide contents of Site 802 sediments, from logs and laboratory determinations. Symbols are as in Figure 10, but with data from Shipboard Scientific Party (1990c). Note the unrealistically low silica and high iron values, which my reflect errors during acquisition or processing of the geochemical logging data. 

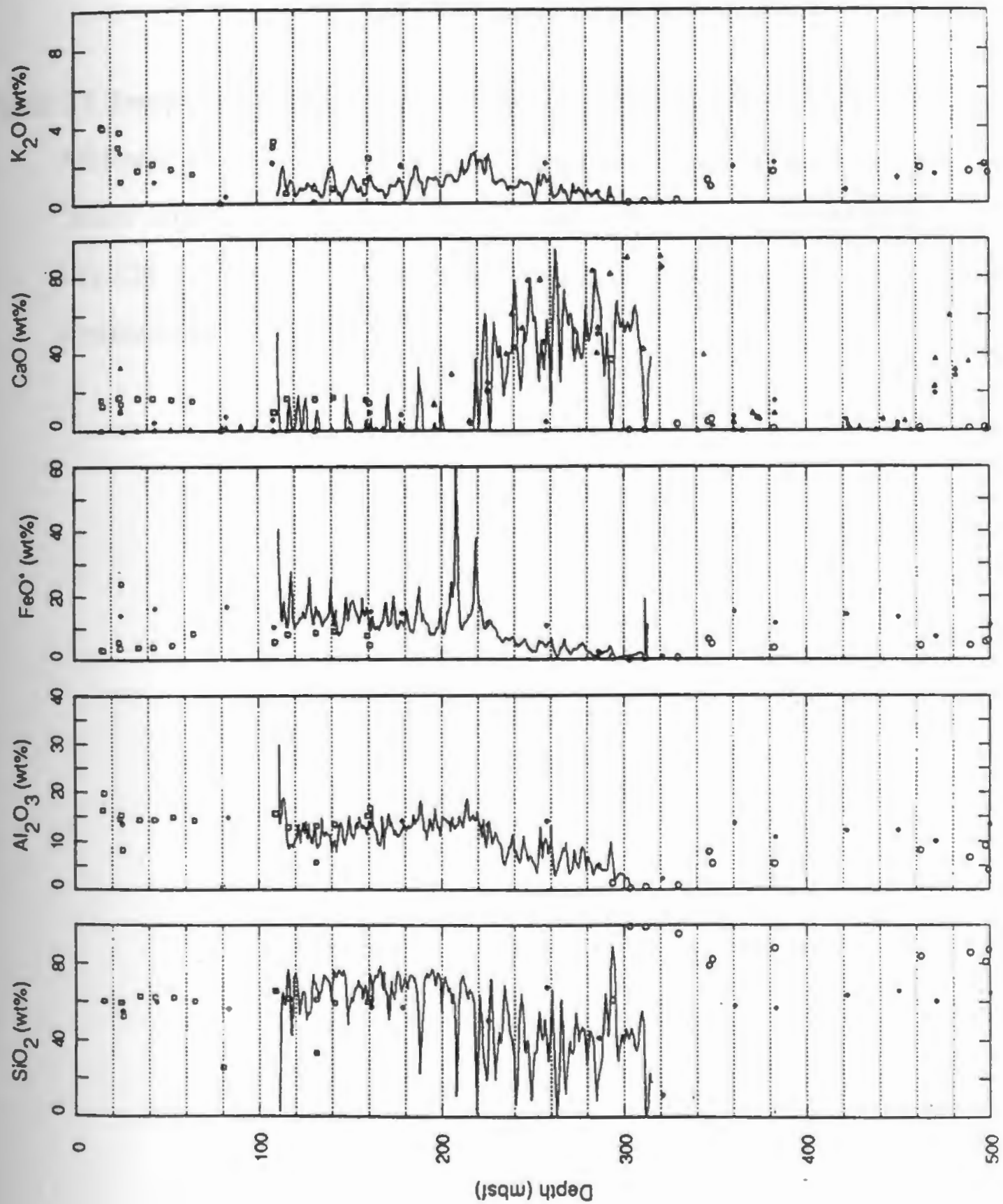
Figure 13. Ternary diagram of normalized $\mathrm{x}$-ray diffraction data from Behl (this volume). All forms of silica (opal, tridymite, and cristobalite) were combined to calculate the "silica" component. These data illustrate that several lithologies identified during Leg 129 can be considered to be mixtures of end members with more extreme compositions. See text for discussion. 


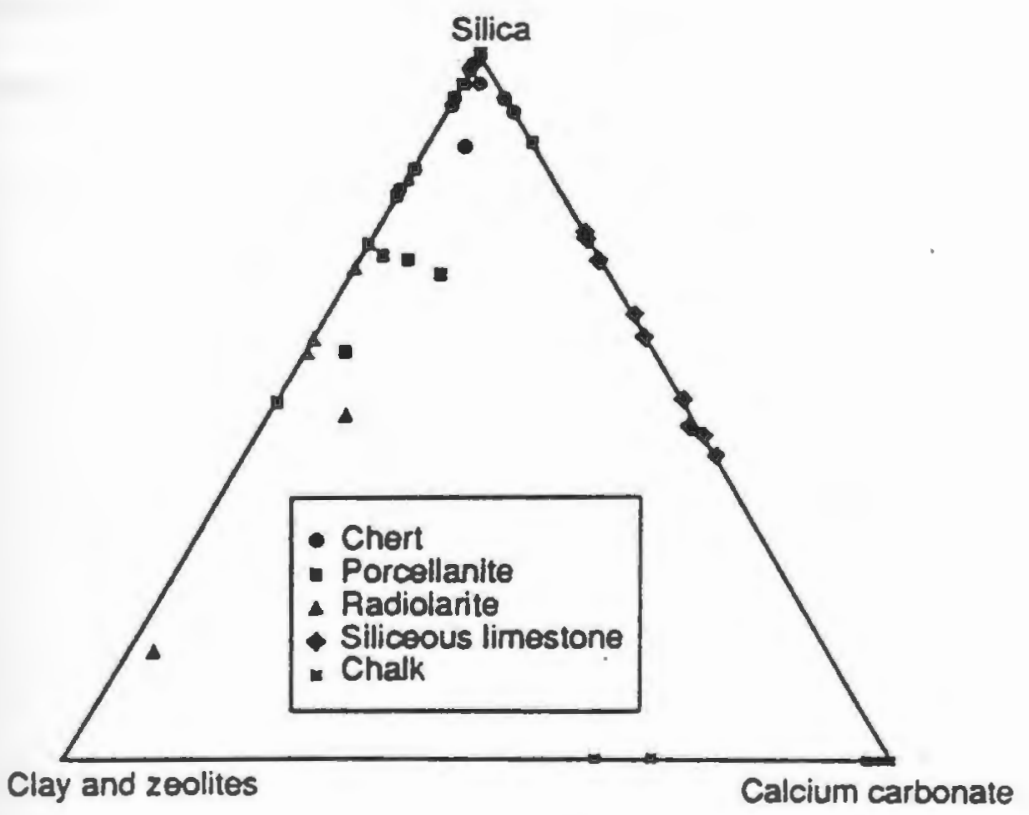


Figure 14. Synthetic oxide and physical-properties logs calculated from an idealized lithologic section composed of mixtures of the five primary lithotypes chosen for use in this study. All possible combinations of mixtures, with weight increments of $20 \%$, were used in this test of inversion stability. Depths are arbitrary. 


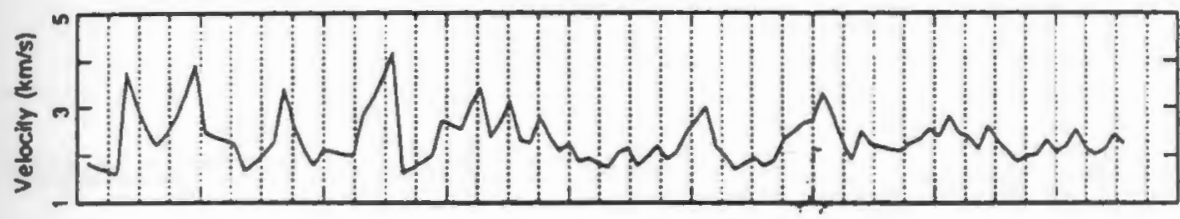

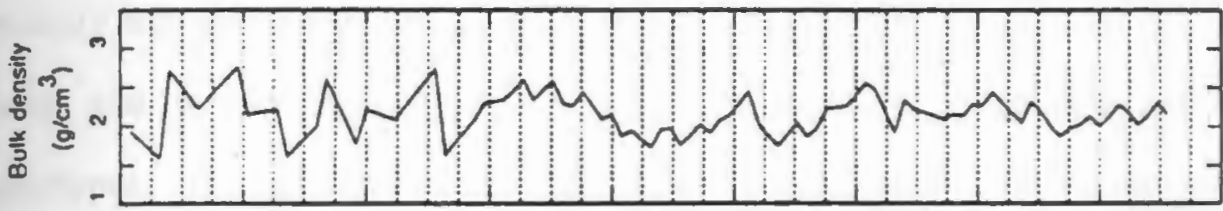

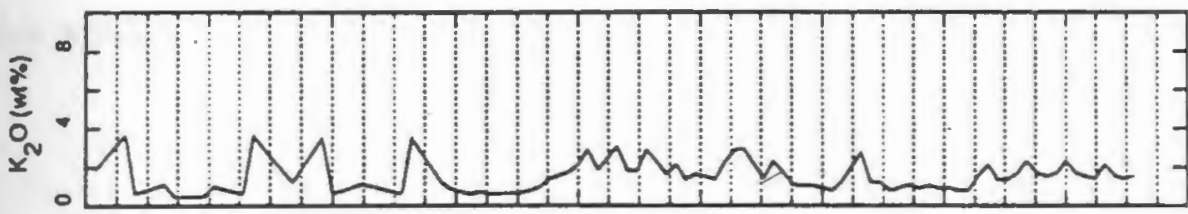
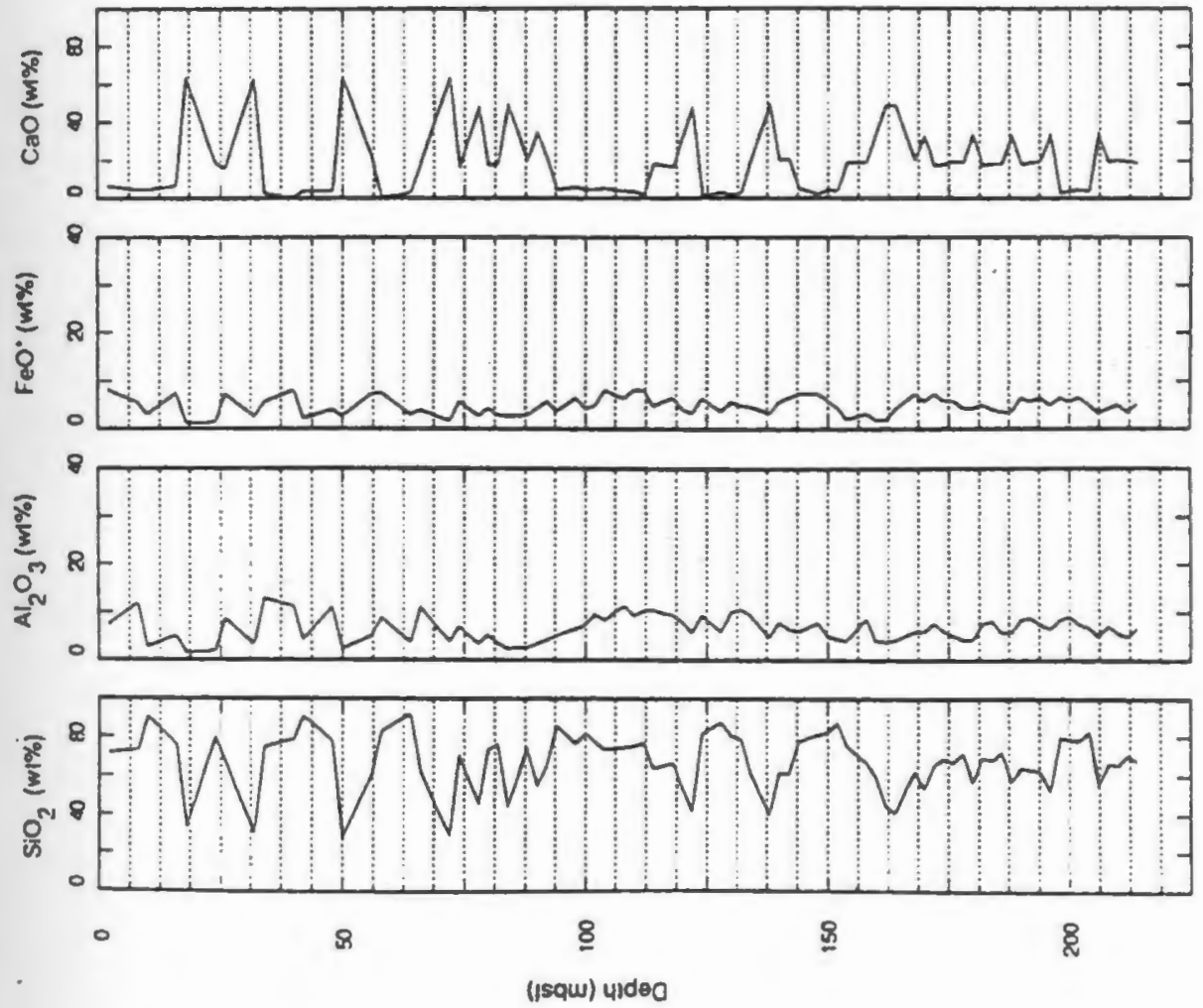
Figure 15. Original (synthetic) and modeled lithologic sections illustrate that (1) the five primary lithotypes used in this study are statistically independent and (2) the five oxide and two physical properties logs are adequate to distinguish between the lithotypes. The standard error is based on the difference between synthetic logs which would be expected from the two lithology columns shown. 

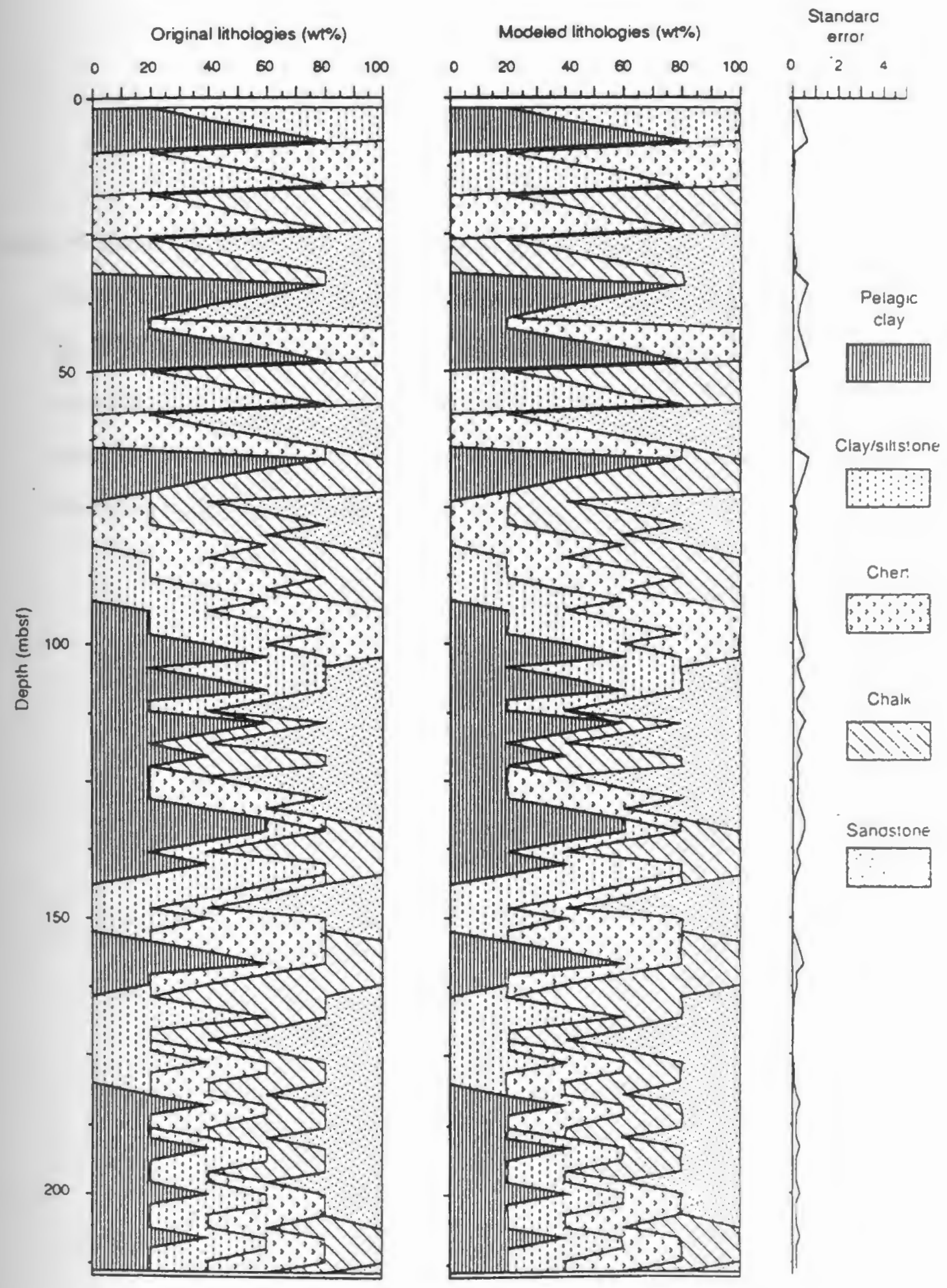
Figure 16. Results of an inversion of the five oxide and two physical-properties logs from Site 800 . The column on the left illustrates cored intervals and recovery, along with the lithology column from Shipboard Scientific Party (1990a). Each of the next five columns illustrate the weight percent of each idealized lithotype that best fits the log data. The two columns on the right give some indication of the goodness-of-fit of the model to the data, as described in the text. 


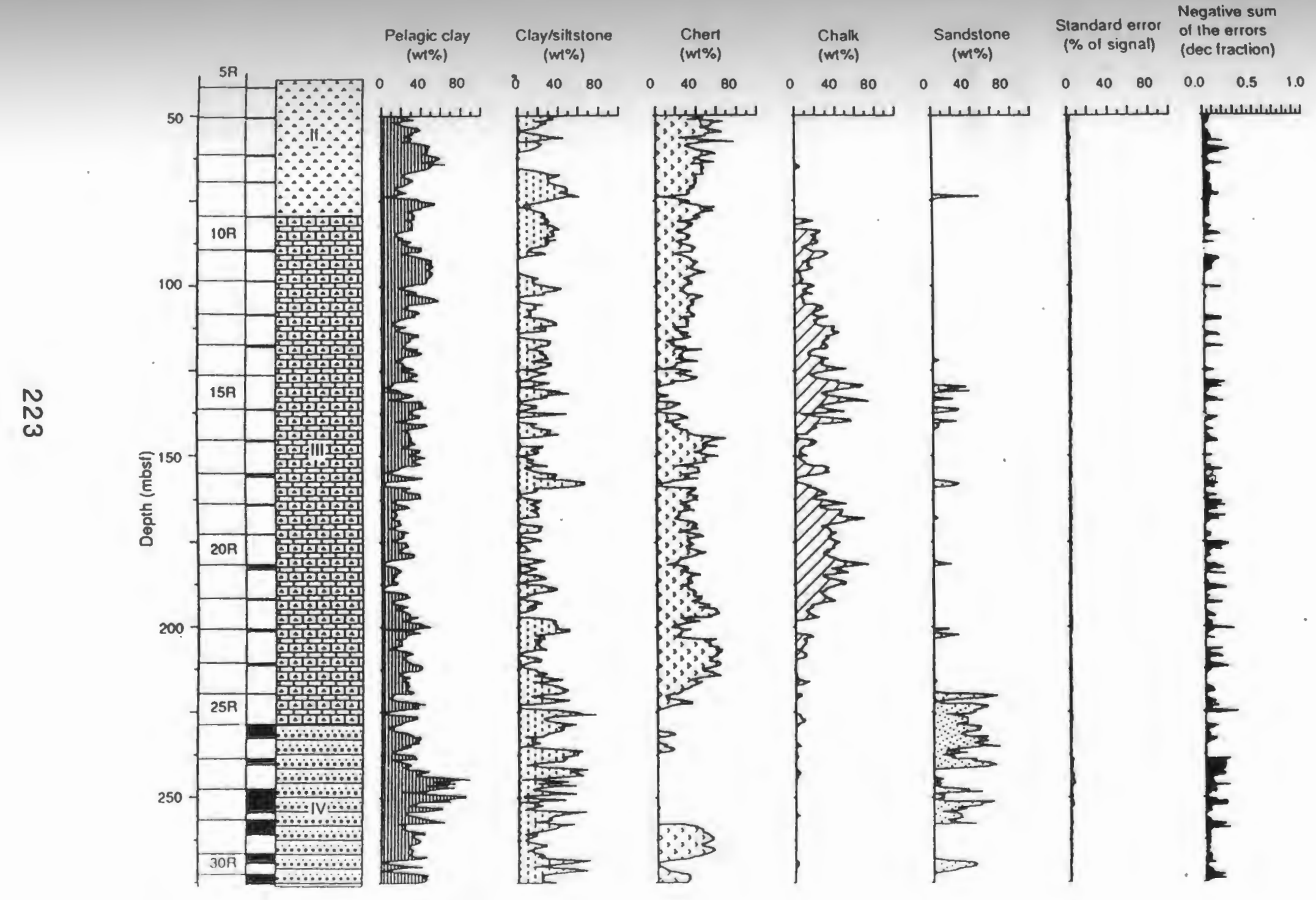


Figure 17. Results of an inversion of the five oxide and two physical-properties logs from Site 801. Columns are as in Figure 16, except that the core data are from Shipboard Scientific Party (1990b). 


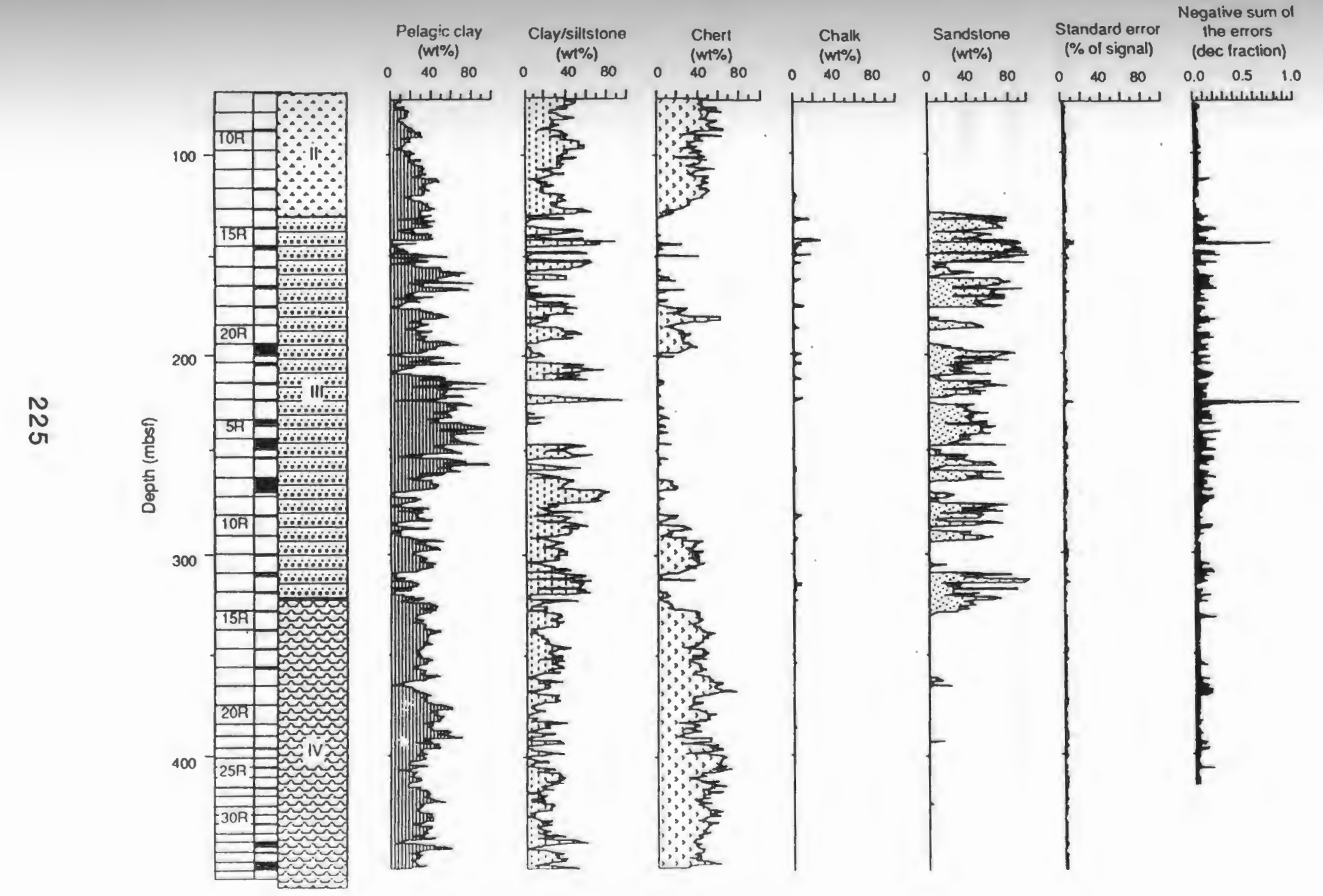


Figure 18. Results of an inversion of the five oxide and two physical-properties logs from Site 802. Columns are as in Figure 16, except that the core data are from Shipboard Scientific Party (1990c). 


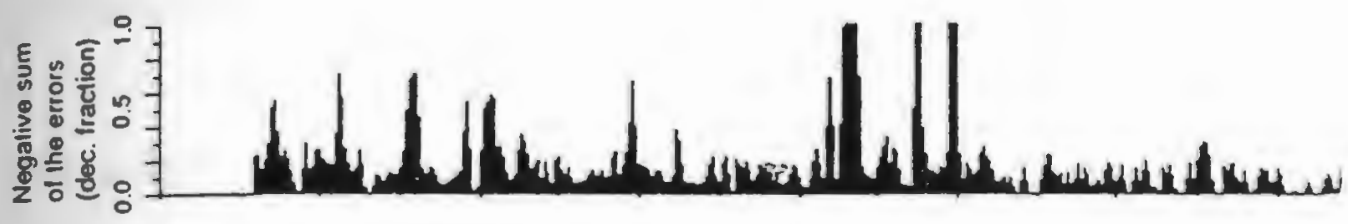

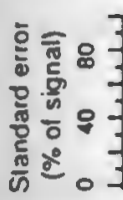

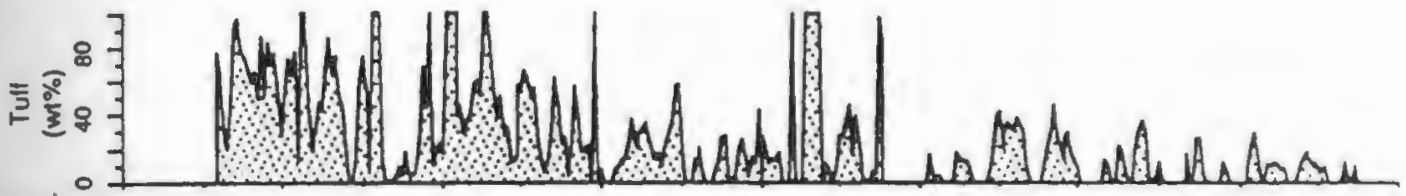
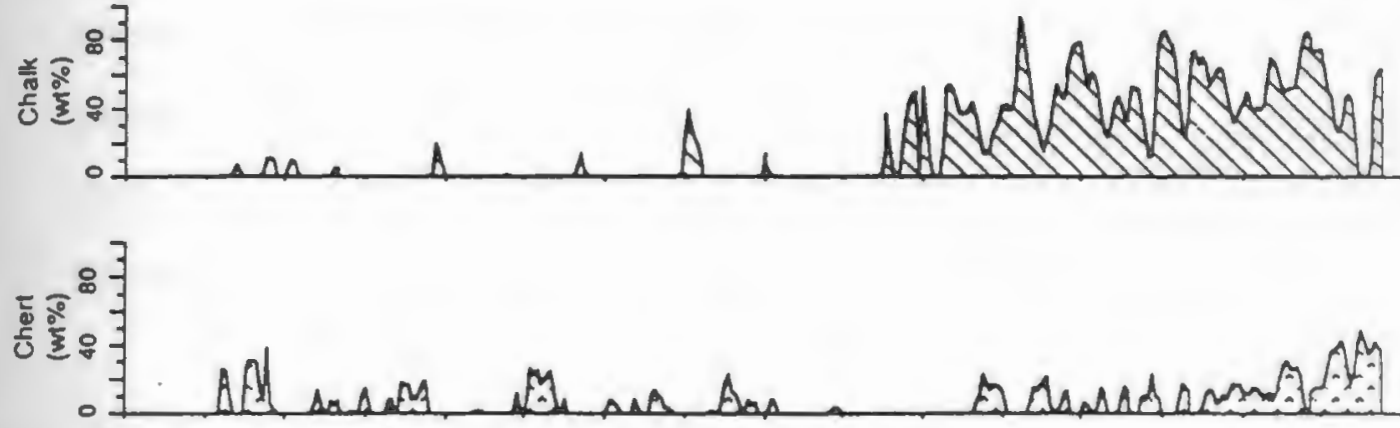

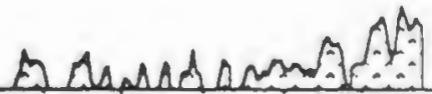

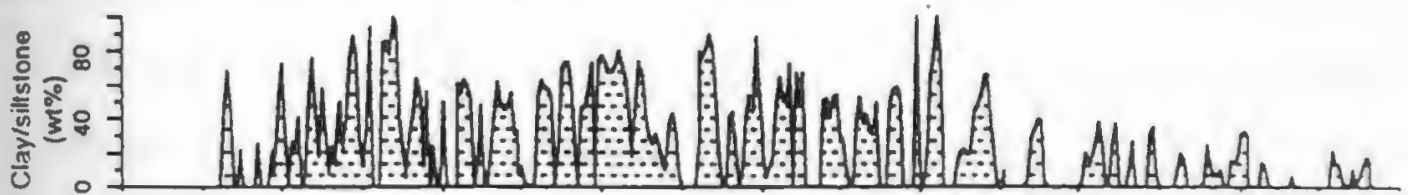
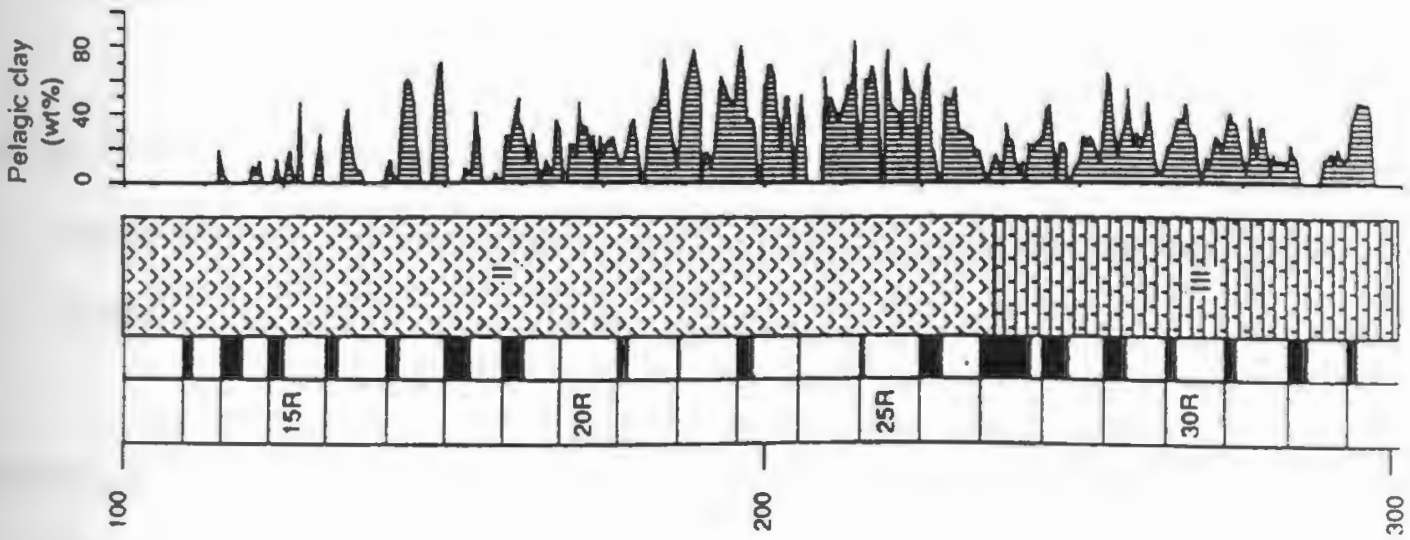

(Isqu) uldeg 


\section{REFERENCES}

Archie, G.E., 1942. Electrical resistivity as an aid in determining some reservoir characteristics. Petroleum Trans. AIME, 146:54-62.

Borehole Research Group, 1990. Ocean Drilling Program Logging Manual, LDGO.

Boyce, R. E., 1976. Definitions and laboratory techniques of the compressional sound velocity parameters and wet-water content, wet bulk density, and porosity parameters by gravimetric and gamma ray attenuation techniques. In Schlanger, S.O., Jackson, E.D., et al., Init Repts. DSDP, 33: Washington (U. S. Govt. Printing Office), 1115-1128.

Busch, W.H., 1989. Patterns of sediment compaction at Ocean Drilling Program Sites 645, 646, and 647, Baffin Bay and Labrador Sea. In Srivastava, S.P., Arthur, M.A., et al., Pro ODP. Sci. Results, 105: College Station, TX (Ocean Drilling Program), $781-790$.

Cannon, D.E. and Coates, G.R., 1990. Applying mineral knowledge to standard log interpretation, Soc. Prof. Well Log Analysts, 31st Annual Logging Symposium, paper V, 23 p.

Carnahan, B., Luther, H.A., and Wilkes, J.O., 1969. Applied Numerical Methods: New York (John Wiley), 604 p. 
Clavier, C., Coates, G., and Dumanoir, J., 1977. The theoretical and experimental basis for the "dual-water" model for the interpretation of shaly sands. Soc. Petrol. Eng, paper 6859.

Doveton, J.H., 1986. Log Analysis for Subsurface Geology: New York (John Wiley), $273 \mathrm{p}$.

Fulthorpe, C. S., Schlanger, S. O., and Jarrard., R. D., 1989. In situ properties of pelagic carbonate sediments on the Ontong Java Plateau, L. Geophys. Res. 94:4025-4032.

Hamilton, E.L., 1971. Prediction of in situ acoustic and elastic properties in marine sediments. Geophysics, 36:266-284.

Hamilton, E.L., 1976. Variations of density and porosity with depth in deep-sea sediments. L. Sediment. Petrol., 46:280-300.

Harvey, P.K., Bristow, J.F., and Lovell, M.A., 1990. Mineral transforms and downhole geophysical measurements. Scientific Drilling, 1:163-176.

Hertzog, R., Colson, L., Seeman, B., O'Brien, M., Scott, H., McKeon, D., Wraight, P., Grau, ' J., Schweitzer, J., and Herron, M., 1989. Geochemical logging with spectrometry tools. L.Soc. Petrol. Eng., 4:153-162.

Jarrard, R.D., Dadey, K.A., and Busch, W.H., 1989. Velocity and density of sediments of Eirik Ridge, Labrador Sea: control by porosity and mineralogy. In Srivastava, S.P., Arthur, M. A., et al., Pro ODP. Sci. Results, 105: College Station, TX 
(Ocean Drilling Program), 811-835.

Lancelot, Y., Larson, R., et al., 1990. Proc. ODP. Init. Repts., 129: College Station, TX (Ocean Drilling Program), 488 p.

Neumann, G., and Pierson, W. J., Jr., 1966. Principles of Physical Oceanography: Englewood Cliffs, NJ (Prentice-Hall), 545 p.

Serra, O., 1986. Eundamentals of Well-log Interpretation: 2. The Interpretation of Logging Data: Amsterdam (Elsevier), 684 p.

Shipboard Scientific Party, 1990a. Site 800. In Lancelot, Y., Larson, R., et al., 1990. Proc. ODP. Init. Repts., 129: College Station, TX (Ocean Drilling Program), 3389.

Shipboard Scientific Party, 1990b. Site 801. In Lancelot, Y., Larson, R., et al., 1990. Proc. ODP. Init. Repts, 129: College Station, TX (Ocean Drilling Program), 91170.

Shipboard Scientific Party, 1990c. Site 802. In Lancelot, Y., Larson, R., et al., 1990. Proc. ODP. Init. Repts., 129: College Station, TX (Ocean Drilling Program), 171243.

van den Oord, R.J., 1990. Experiences with geochemical logging. Soc. Prof. Well Log Analysts, 31st Annual Logging Symposium, paper TT, 24 p. 
Von Herzen, R.P., Francis, T.J.G., and Becker, K., 1983. In situ large-scale electrical resistivity of oceanic crust, Hole 504B. In Cann, J. R., Langseth, M. G., et al., Init. Repts. DSDP, 69: Washington (U.S. Govt. Printing Office), 237-244.

Waxman, M.H., and Smits, L.J.M., 1968. Electrical conductivities in oil-bearing shaly sands. L. Soc. Pet. Eng, 8:107-122.

Wendlandt. R.F., and Bhuyan, K., 1990. Estimation of mineralogy and lithology from geochemical log measurements. Am. Asso. Petrol. Geol. Bull, 74:837-856.

Winsauer, W.O., Shearin, H.M., Jr., Masson, P.H., and Williams, M., 1952. Resistivity of brine saturated sands in relation to pore geometry. Am. Asso. Petrol. Geol. Bull., 36:253-277. 
APPENDIX A - Models of lithospheric flexure in the EMB and PB

\section{INTRODUCTION}

In Manuscript I and II it was suggested that the Ogasawara Fracture Zone (OFZ), Magellan Seamounts and associated flexural moat had significant control over the source and distribution of redeposited sediments. It was also proposed that the pre-existing OFZ had some influence over the location of edifice building volcanism in the Cretaceous. In this appendix I present a more detailed account of the morphologic and geophysical attributes observed in the area of seafloor which separates the PB from the EMB. Selected profiles of Horizon B are modeled as the surface of a loaded elastic plate in an attempt to quantify the observation that the depth profile of sediment unloaded Horizon B often appears flexural in shape as seamounts are approached, and in particular as the OFZ area is crossed. The results of this modeling effort are presented and allow further hypotheses concerning the shape of the Horizon B surface and implications for the volcanic and thermal history of these basins.

Observations concerning morphology of the OFZ area are derived from the bathymetry map of Angell and Brenner (in press, 1992) (Figure 1) and from two separate vertical incident seismic profiles acquired during FM35-12 (figure 2b) and MESOPAC II (figure $2 \mathrm{a}$ ) expeditions. The geophysical data discussed involves previously identified seafloor magnetic anomalies, regional satellite altimetry data and geophysical investigations of specific seamounts within this study area.

\section{OGASAWARA FRACTURE ZONE AND MAGELLAN FLEXURAL MOAT?}

The existence of the Ogasawara Fracture Zone (OFZ) in this area of the EMB and PB was first proposed by Tamaki et al. (1987) and Handschumacher et al. (1988) based on their identification of correlated magnetic anomalies which are offset approximately 500 - 
$600 \mathrm{~km}$ left-laterally from the EMB to the PB (Figure 1). The fracture zone(s) that offset these lineations is inferred to lie somewhere within a rectangular area approximately 300 $\mathrm{km}$ wide which divides the two basins. Seamounts of the Magellan group are scattered within this region and appear to be aligned approximately perpendicular to magnetic lineations and thus lie along the trend inferred for a fracture zone offset. The morphologic expression of the OFZ, however, is only defined along two seismic profiles (figures 1, 2).

The spacial offset of magnetic lineations implies an age difference of $\sim 6-7 \mathrm{~m} . \mathrm{y}$. between the oceanic crust of the EMB (younger) and that of the PB, assuming a constant half spreading rate of $80 \mathrm{~mm} / \mathrm{yr}$. The oceanic crust at Site 801 in the PB has been radiometrically dated at $166.8+/-4.5 \mathrm{Ma}$ (Pringle, in press 1992) in good agreement with the age predicted for this site prior to drilling (Lancelot, Larson et al., 1990). Thus the crust in the EMB should also be of great age but slightly younger than at Site 801 .

Important Observations

The variation in depth to seafloor and Horizon B across the OFZ along two seismic lines $200 \mathrm{~km}$ apart is shown in figure 2. The clear difference of approximately $300 \mathrm{~m}$ in the seafloor depth from the $5900-6000 \mathrm{~m}$ in the EMB to $5600-5700 \mathrm{~m}$ in the PB, is well beyond, and in the opposite sense of depth differences predicted across a fracture zone separating such old seafloor. In addition, both profiles show that Horizon B remains anomalously deep ( $600-700 \mathrm{~m}$ deeper ) over an 80 to $100 \mathrm{~km}$-wide zone. The trough of the OFZ(s) is inferred to lie within this anomalously deep zone which is much wider than an entire transform domain (20-60 km) typically observed for any single fracture zone offset (Fox and Gallo, 1984). Thus this anomalously wide and deep trough may be the result of multiple fracture zone offsets or a diffuse zone of deformation as observed for the Molakai and Murray Fracture Zones west of Hawaii (Mammerickx and Smith, 1985; Sager and Pringle, 1987). 
Sediment unloaded Horizon B, derived from our seismic profiles, plunges approximately $600 \mathrm{~m}$ over $32 \mathrm{~km}$ as this inferred fracture zone is approached along a FM35-12 seismic line from the EMB across DSDP 585 toward the PB (figure 2b, figure 1 location, figure 3). The deepening of Horizon B over distances of $20-40 \mathrm{~km}(\sim 19 \mathrm{~m} / \mathrm{km})$ is comparable to that observed for oceanic crust proximal to large offset fracture zones in the North Pacific (e.g. Mendocino). In contrast, depth to Horizon B does not change at all approaching the OFZ from the PB but simply terminates against an un-named seamount (right side figure $2 \mathrm{~b}$ ). However, $200 \mathrm{~km}$ further to the north along a MESOPAC II seismic line from the PB toward the EMB Horizon B appears to deepen over a much broader zone, approximately $640 \mathrm{~m}$ over a distance of $\sim 120 \mathrm{~km}$ (figure $2 \mathrm{a}$ right side, figure 4). This latter profile is reminiscent of the moat and outer rise bathymetry surrounding many seamounts/islands which have been explained as the flexural response of the elastic lithosphere to a vertical load (Walcoth, 1970; Watts, 1978).

Thus there appears to be morphologic, tectonic and geophysical evidence for both fracture zone and flexural effects within the region separating these two basins.

\section{FLEXURAL MODELS}

In order to further constrain the inference of flexure in the EMB and PB, profiles of Horizon B across the OFZ have been modeled according to the following algorithm:

\section{Meorithm for calculation of flexural models}

1) Definition of symbols (modified from Turcotte and Schubert, 1986);

$\mathrm{D}=$ flexural rigidity $(\mathrm{N}-\mathrm{m})$

$\lambda=$ flexural wavelength $(\mathrm{m})$

$\rho_{m}=$ mantle density $3300 \mathrm{~kg} / \mathrm{m}^{3}$ 
$\rho_{w}=$ water density $1030 \mathrm{~kg} / \mathrm{m}^{3}$

$\mathrm{E}=$ Young's modulus $1 \times 10^{11} \mathrm{~N} / \mathrm{m}^{2}$ (Watts et al., 1980)

$\sigma=$ Poisson's ratio .25

$\omega_{0}=$ observed relative deflection (m)

$\mathrm{g}=$ gravitational acceleration $9.8 \mathrm{~m} / \mathrm{s}^{2}$

$\mathrm{T}_{\mathrm{e}}=$ elastic plate thickness $(\mathrm{m})$

$\mathrm{V}_{\mathrm{o}}=$ vertical line load $(\mathrm{N} / \mathrm{m})$

2) Digitize seafloor and Horizon B reflections from seismic profiles.

3) Calculate depth to Horizon B after sediment removed following Crough (1978).

a) Corrected Horizon B depth $=$ seafloor depth $+[.6 \mathrm{x}$ sediment thickness $(\mathrm{m})]$

4) Estimate the flexural wavelength $(\lambda)$ and relative deflection $\left(\omega_{0}\right)$ from direct measurement of unloaded Horizon B profiles.

5) Given basic observations of $(\lambda)$ and $\left(\omega_{0}\right)$ calculate the flexural profile most closely matching observed profile according to Turcotte and Schubert (1986) and ascertain the corresponding elastic thickness $\left(T_{e}\right)$. The following formulation is for the deflection of $a$ broken elastic plate by a line load. Similar calculations (not shown) were also performed assuming a continuous elastic plate. The differences between broken versus continuous elastic plate models are discussed in the next section. 
a) observed flexural wavelength $(\lambda)$

$$
\lambda=\frac{1}{2} \pi \alpha_{b}
$$

solve for flexural parameter $\left(\alpha_{b}\right)$

b) flexural parameter =

$$
\alpha_{b}=\left[\frac{4 D}{\left(\rho_{m}-\rho_{w}\right) g}\right]^{\frac{1}{4}}
$$

solve for flexural rigidity (D)

c) flexural rigidity (D) =

$$
D=\frac{E T_{e}^{3}}{12\left(1-\sigma^{2}\right)}
$$

solve for elastic thickness $\left(T_{e}\right)$

d) observed maximum deflection $\left(\omega_{0}\right)=$

$$
\omega_{0}=\frac{V_{0} \alpha_{b}^{3}}{4 D}
$$

adjust the vertical load $\left(\mathrm{V}_{0}\right)$ to match observed maximum deflection $\left(\omega_{0}\right)$

e) The shape of the deflected elastic plate with range $\left(\omega_{x}\right)$ is defined:

$$
\begin{aligned}
& \text { where } x \text { increases away from the load, } \quad \omega_{x}=\frac{v_{0} \alpha_{b}^{3}}{4 D} \frac{-x}{\alpha} \cos \frac{x}{\alpha} \\
& \text { at } x=0 \text { deflection is maximum }\left(\omega_{0}\right) \\
& \text { at } x \approx \infty \quad \omega_{x} \approx 0
\end{aligned}
$$


Results

The wavelength of the flexural bathymetry is a function of the effective elastic thickness $\left(T_{e}\right)$ of the lithosphere, while the amplitude of the flexure (deflection $V_{0}$ ) depends on both $T_{e}$ and the applied bending moment or vertical load $\left(\omega_{0}\right)$. Flexure studies of subducting oceanic lithosphere and lithosphere loaded by the Hawaiian-Emperor chain have shown that the effective elastic thickness of the lithosphere is approximately proportional to (age of lithosphere)1/2 (Watts, 1978; Caldwell and Turcotte, 1979; Watts et al., 1980; Bodine et al., 1981). This behavior basically reflects the age-dependant thermal structure of the lithosphere and the strong temperature-dependence of the creep process which tend to relieve flexural stresses. The division between the upper (cooler) elastic and lower (hotter) viscous portions of the lithosphere occurs at a temperature between 300 and $600^{\circ} \mathrm{C}$ according to Watts et al. (1980).

Results of the modeling are illustrated in figures 5 and 6. These models assume a simplified load distribution represented by a 2-D line load which deflects the elastic plate. Two calculations were made for each observed profile (profiles A and B). The first assumes the elastic plate is broken along the line load (broken plate model), the second assumes the elastic plate remains continuous to either side of the line load (continuous plate). The approximation of the true load distribution by a line load rather than individual 3-D loads representing individual seamounts was used for the following reasons; The Magellan Seamounts appear to be aligned along the trend inferred for the OFZ. Individual seamounts are scattered within an area $\sim 300 \mathrm{~km}$ wide that extends northwest-southeast for over $1000 \mathrm{~km}$. Furthermore at least two large seamounts are within $30-150 \mathrm{~km}$ range of the modeled seismic profiles and so are close enough that overlapping effects of seamount loading is expected. The complications and implications arising from modeling the overlapping effects of multiple proximal seamounts including the effects of moat infill are not justified for just two widely spaced seismic profiles. A 2-D line load and a load 
represented by a 3-D body are end-member approximations for the actual load distribution and their relative effects on a flexural profile can be qualitatively assessed. Most importantly for the models presented here is that regardless of the load distribution assumed, the observable flexural wavelength $(\lambda)$ will not change (Watts et al., 1975). The greatest difference is that a line load produces approximately four times the deflection, but for these models this is not the key observation (this becomes critical only when gravity and bathymetry are combined to constrain flexural models). The observed flexural wavelength will, however, depend on its azimuth with respect to a given load distribution. If the profile is perpendicular to the line load or along a radius centered on the 3-D load then the observed flexure is equal to model flexure. If the profile approaches the line load at a high angle then flexural wavelength is overestimated and therefore $\mathrm{Te}$ is overestimated and if the profile does not directly transect the center of the 3-D individual seamount load then flexural wavelength will be underestimated (Te underestimated).

The choice of broken or continuous elastic plate models also represent end-member possibilities for the calculation of Te. For a given observed deflection and flexural wavelength the broken plate model will result in a larger vertical load and larger Te than for a continuous plate model. Intra-plate volcanism in the form of volcanoes and elongate ridges that are localized along and within fracture zones is well documented and has been used as an argument for a weakened lithosphere (possibly decoupled) along fracture zones (Vogt, 1974; Batiza, 1981; Lowrie et al., 1986, Mcnutt et al., submitted). The Magellan Seamounts aligned along the OFZ may be another example of the vulnerability of lithosphere at a fracture zone to off-ridge volcanism and if so favors a broken plate model for this study. Other studies of fracture zone morphology and geoid indicate that fracture zones remain locked outside the transform domain (Schubert and Sandwell, 1982) and the apparent aseismic nature of fractures zones indicate that these features are not zones of weakness. These results indicate that lithosphere across a fracture zone should be 
modeled as a continuous plate. In the following sections both broken and continuous plate models are considered, the $\left(\mathrm{T}_{\mathrm{e}}\right)$ derived from each of these models will be referred to as $\left(B T_{e}\right)=$ broken plate and $\left(C_{e}\right)$ for continuous plate.

The seismic image of Horizon B along a track heading southeast out of the PB towards the EMB (Figure 3, figure 1 profile B) can be modeled by an elastic plate with $\mathrm{BT}_{\mathrm{e}}=28.5 \mathrm{~km}$ or $\mathrm{CT}_{\mathrm{e}}=16.9 \mathrm{~km}$. The broken plate model results in a better match to the observed profile (figures 5 and 6 profile $B$ ). Watts et al. (1980) find that $T_{e}$ increases with age of the lithosphere at time of loading and that there is good agreement between $T_{e}$ and the depth to the 300 to $600^{\circ} \mathrm{C}$ isotherm based on the boundary layer model (BLM) of Parsons and Sclater (1977). Subsequent studies of large numbers of seamounts throughout the world's ocean basins have shown that the depth to the $4000 \mathrm{C}$ isotherm offers the best approximation for $T_{e}$ (Calmant and Cazenave, 1987). In the following discussion the model derived estimates for Te will be compared to Te as approximated by the depth to the $400 \circ \mathrm{C}$ isotherm unless otherwise noted.

\section{INTERPRETATION}

The large value of $28.5 \mathrm{~km}$ for $\mathrm{BT}_{\mathrm{e}}$ indicates that the load (the Magellan Seamounts) was emplaced when the Pacific Plate within the Pigafetta Basin was no younger than $43 \mathrm{~m} . y$. (e.g. the depth to the 600 isotherm $=28.5 \mathrm{~km}$ at $43 \mathrm{~m} . \mathrm{y}$.) and if the $400{ }^{\circ} \mathrm{C}$ isotherm is used the age of loading is as high as $110 \mathrm{Ma}$. This result implies a crustal age of $196 \mathrm{Ma}$ (i.e. age of most proximal seamount $+110 \mathrm{Ma}$ ). The much lower $\mathrm{CT}_{\mathrm{e}}$ value of $\sim 17 \mathrm{~km}$ indicates a loading age of $\sim 40 \mathrm{Ma}$, that is a crustal age of $126 \mathrm{Ma}$ (i.e. age of most proximal seamount +40 ). These implied ages bound those derived from radiometric dating of the oceanic crust at Site 801 in the PB ( 167 Ma), basalts dredged from Ita Mai Tai Guyot ( 120 Ma) and an another unnamed Magellan seamount ( $86 \mathrm{Ma})$ that indicate a 47 to 81 m.y. age difference between load and crust (dates from Pringle, 
1992; Pringle, in press; Winterer et al., in press). In addition, 3-D models of the high-amplitude (254 mgal), long-wavelength free air gravity anomaly over Ita Mai Tai Guyot indicate that this guyot is almost completely uncompensated locally (Wedgeworth and Kellogg, 1987). These authors concluded that Ita Mai Tai was formed on oceanic crust at least 30-40 m.y. old (e.g. Jurassic). Such a conclusion is strengthened by studies of geoid heights measured using radar altimeters on board orbiting satellites. Watts and Ribe (1984) show that seamounts emplaced on relatively young lithosphere on or near a spreading axis will be associated with relatively low amplitude geoid anomalies ( 0.4-0.5 $\mathrm{m} / \mathrm{km}$ of seamount height), while seamounts formed on relatively old lithosphere (off ridge) will be associated with significantly higher amplitude geoid anomalies (1.4-1.5 $\mathrm{m} / \mathrm{km}$ ). Fortuitously, one of the satellite tracks analyzed by Watts and Ribe (1984) (their figure 13a) crosses over the two seamounts most proximal to our seismic profiles ( labeled "86" and Ita Mai Tai in figure 1) for which published radiometric dates are also available (e.g. 86 and $120 \mathrm{Ma}$ respectively). They conclude that these two seamounts, in particular, as well as the Magellan and Marcus-Wake seamount provinces in general, were formed off ridge on crust older than the seamounts themselves. These observations and flexural models strongly support the inference that the gradual deepening of Horizon B illustrated in figures 3 and 5 (profile B) and in other areas of the PB is a result of flexural bending due to a seamount(s) load significantly younger than the underlying lithosphere. In fact, these studies indicate that large seamounts in the PB and EMB should be associated with flexural moats with half wavelengths on the order of $100-150 \mathrm{~km}$.

There are, however, several possible explanations for the shorter wavelength deepening of the Horizon B profile approaching the OFZ area from the EMB towards the PB (figures 1, 2b, 5 and 6 profile A). The most obvious, considering the offset magnetic lineations, is that this profile is the result of some combination of anomalously thin oceanic crust and dynamic deepening of the crust acquired at a transform offset of the Pacific- 
Izanagi spreading axis. The scale of deepening (600m over $\sim 20-40 \mathrm{~km}$ range) is comparable to that observed both on and off axis as fracture zones are approached along the East Pacific Rise (Macdonald, 1988) and off-axis in the North Pacific (e.g. Mendocino FZ). Alternatively, profile A (figures $1,2 b, 5$ and 6 ) can be modeled by a loaded elastic plate. The best fit model result in an effective elastic thickness of only $\mathrm{BT}_{\mathrm{e}}=5 \mathrm{~km}$ or $\mathrm{BT}_{\mathrm{e}}$ $=2.8 \mathrm{~km}$ and a seamount load an order of magnitude less than that used to model Profile $B$ (figures 5,6 ). This estimate for $T_{e}$ implies that the thermal age of the lithosphere is equal to the age of the load (Watts et al., 1980), in this case $~ 120 \mathrm{Ma}$ (i.e., age of most proximal seamount - Ita Mai Tai). An attempt was made to model the discontinuous Horizon B surface on the EMB side of the OFZ (figure 2a leftside) the results (not shown) indicate $\mathrm{a} \mathrm{BT}_{\mathrm{e}}$ of $13 \mathrm{~km}$ which implies a loading age of $23 \mathrm{Ma}$ and therefore a thermal lithospheric age of $109 \mathrm{Ma}$ (i.e., age of most proximal seamount + $23 \mathrm{Ma}$ ).

Finally, the differences observed on Horizon B profiles approaching the OFZ from the EMB (figures 1, 2a leftside) or from the PB (figures 1, 2b rightside) may be more a function of the discontinuous nature of the sill/flow overburden and the thickness of moat filling volcanic debris, not directly related to the true shape of the underlying crustal surface. In this case Horizon B profiles cannot be used to infer the thermal state of the lithosphere through flexural studies or to reveal the morphology of the OFZ trough.

\section{Implications for the observation of flexure of Horizon B}

Throughout this analysis the basic assumption has been that Horizon B, if not the top of oceanic crust, closely mimics the long wavelength crustal surface. This dissertation has shown that Horizon B in the majority of the EMB and southeastern PB represents the top of mid-Cretaceous sills/flows overlying Jurassic crust.

Several conclusions can be made based on the presence or absence of a flexural Horizon B profile in these basins. Where flexure is observed on seismic profiles proximal to large seamounts, Horizon B either represents the top of oceanic crust or the surface of 
younger sills/flows which mirror the shape of the underlying crust. In the latter case, the sills/flows are inferred to have been emplaced prior to or simultaneously with the deflection of the underlying crust and thus no younger than the seamount load (e.g. profile B and figure 4). Alternatively, if Horizon B remains flat-lying on an adjacent profile approaching the same seamount or one similar in size (right side figure $2 \mathrm{~b}$ ) then this surface most likely represents the top of younger sillsfllows which obscure the true shape of underlying oceanic crust. This reflection geometry indicates that the sills/flows were emplaced simultaneously with or after seamount construction.

The convincing observational and model evidence for flexure along the southwest margin of the PB, specifically the comparable values for calculated $\mathrm{Te}$ and the Te predicted given the radiometric age control on load and crustal age implies that the elastic lithosphere beneath the PB was not significantly thinned $\left(B T_{e}=28.5\right)$ or was slightly thinned $\left(C T_{e}=\right.$ 16.9) prior to or during the mid-Cretaceous volcanic event which created the Magellan seamounts.

If the observed Horizon B profile (profile A ) along the eastern Margin of the EMB is also interpreted as flexure $\left(T_{e}=5 \mathrm{~km}\right)$ due to a seamount load there are two possible interpretations. The first, is that the seamount load and lithosphere are both midCretaceous in age. This conclusion is contrary to those based on most geophysical observations in the EMB which indicate that Jurassic oceanic crust is overlain by midCretaceous flows/sills. However, drilling in the EMB has still not recovered any Jurassic material and geochemically, radiometrically and morphologically the pillow units recovered in the EMB could represent either the top of mid-Cretaceous age oceanic crust or flows/pillows overlying Jurassic crust. The second possibility is that the lithosphere beneath the EMB is Jurassic but was significantly thinned (re-heated) prior to or during the mid-Cretaceous volcanic event that resulted in vast deposits of deep sea sills/flows associated with the construction of the world's largest oceanic plateau (Ontong-Java). 
Elastic plate thicknesses derived from an analysis of gravity and Sea Beam bathymetry data over Himu and Hemler seamounts (figure 1) are also unusually thin (10-15 km) (Smith et al., 1987). These authors concluded that the Jurassic age lithosphere in that portion of the PB was re-heated prior to or during the emplacement of these seamounts, thus resetting the thermal age to approximately $130 \mathrm{Ma}$.

The depth to sediment unloaded Horizon B in the EMB is 6200-6300 mbsf which is essentially that predicted by the BLM of Parson and Sclater (1977) for oceanic crust of $114 \mathrm{Ma}$ or by the plate model for crust $\sim 165 \mathrm{Ma}$. The heatflow value of $46.8 \mathrm{~mW} / \mathrm{m}^{2}$ (Lister et al., 1990) measured in the EMB $280 \mathrm{~km}$ west of ODP Site 802 is significantly higher than predicted for crust $114 \mathrm{Ma}$ (e.g. $40.3 \mathrm{~mW} / \mathrm{m}^{2}-43.1 \mathrm{~mW} / \mathrm{m}^{2}$ for BLM or plate model respectively). These depth and heatflow values are not entirely consistent with either mid-Cretaceous age crust cooling and subsiding according to the BLM or re-heated Jurassic age crust following a plate model cooling curve.

\section{CONCLUSIONS}

Large seamounts in the PB and EMB should be associated with flexural moats. Such deepening of Horizon B is only apparent in the PB and then only part of the time. The deepening of Horizon B approaching the OFZ and Magellan Seamounts from the PB is attributed to the loading of the lithosphere by a seamount chain. Flexure on the PB side of the OFZ and Magellan Seamounts suggests that the actual location of the inferred fracture zone trough lies further west along the northeastern margin of the EMB.

The Horizon B profile approaching the OFZ and Magellan Seamounts from the EMB is most likely due to a combination of fracture zone effects with the random emplacement of sills/flows overlying oceanic crust. However if these profiles are the result of flexure due to the Magellan Seamounts then the Te values obtained indicate that the Jurassic age crust in the EMB was thermally rejuvenated to $\sim 110-120 \mathrm{Ma}$. Where 
Horizon B remains flat-lying and undeflected proximal to large seamounts, this surface is interpreted as sills/flows of the same age as the seamount which overlie oceanic crust. 
Figure 1. Bathymetry of the central western Pacific modified from M. Angell and C. Brenner (1992 in press) with location (solid dots) of selected DSDP sites and all of ODP Leg 129 sites. The $5500 \mathrm{~m}$ contour is highlighted and the $3000 \mathrm{~m}$ contour is shown as a lighter line. The location of MESOPAC II and Fm35-12 seismic lines crossing the OFZ are labeled figure $2 a$ and figure $2 b$ respectively and refer to the corresponding line drawings shown in figure 2. Bold solid lines mark the location of profiles A and B displayed in figures 2, 3, 4 and 5. Magnetic anomalies modified from Handschumacher and Gettrust (1985), Tamaki et al. (1987) and Handschumacher et al. (1988). The broad zone inferred for the location of the Ogasawara FZ is bounded by the dashed line. Radiometric ages of basalt are given in Ma for Leg 129 Sites from Pringle (in press), and for seamounts from Ozima et al. (1983), Keating et al. (1984), Pringle, (pers. comm. 1991), Pringle (1992), and Winterer et al., (in press). Note: Grand Pacific is referred to as "D4" in Ozima et al., 1983. 


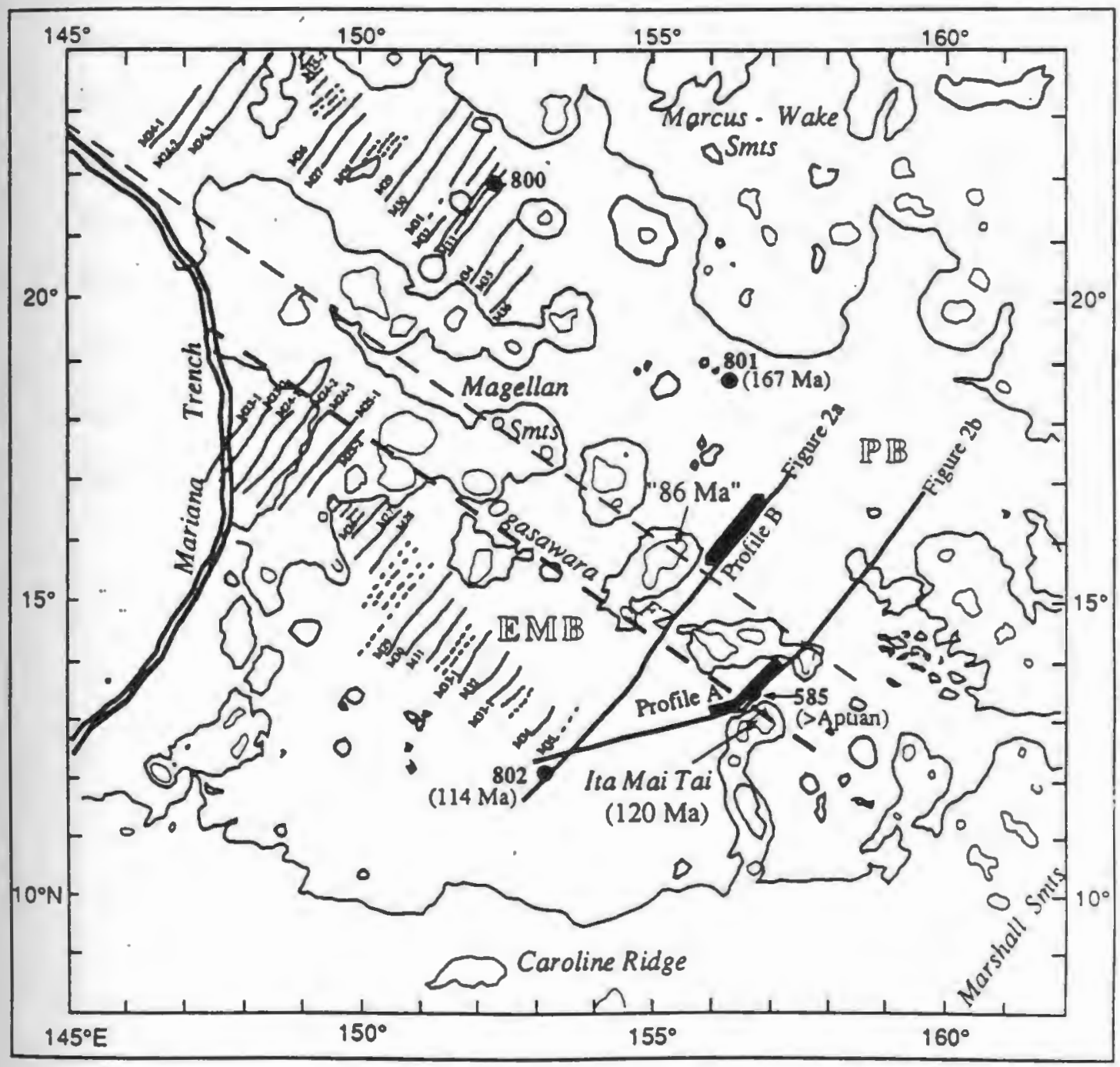


Figure 2a,b. Two $\sim 1000 \mathrm{~km}$ long profiles showing selected reflections digitized from near channel watergun data (see figure 1 track chart for locations). The deepest heavy line always represents Horizon B; the top of high velocity igneous material. This horizon is characterized and interpreted from direct sampling at three widely separated ODP sites, reflection character and from velocity structure. Note that Horizon B in profile appears quite different between lines and on either side of the OFZ. The top lighter line represents the seafloor. Dashed boxes locate the seismic images presented in figures 3 and 4. Profiles A and B are shown in figure 5. Radiometric ages are from Pringle (1992 in press). 

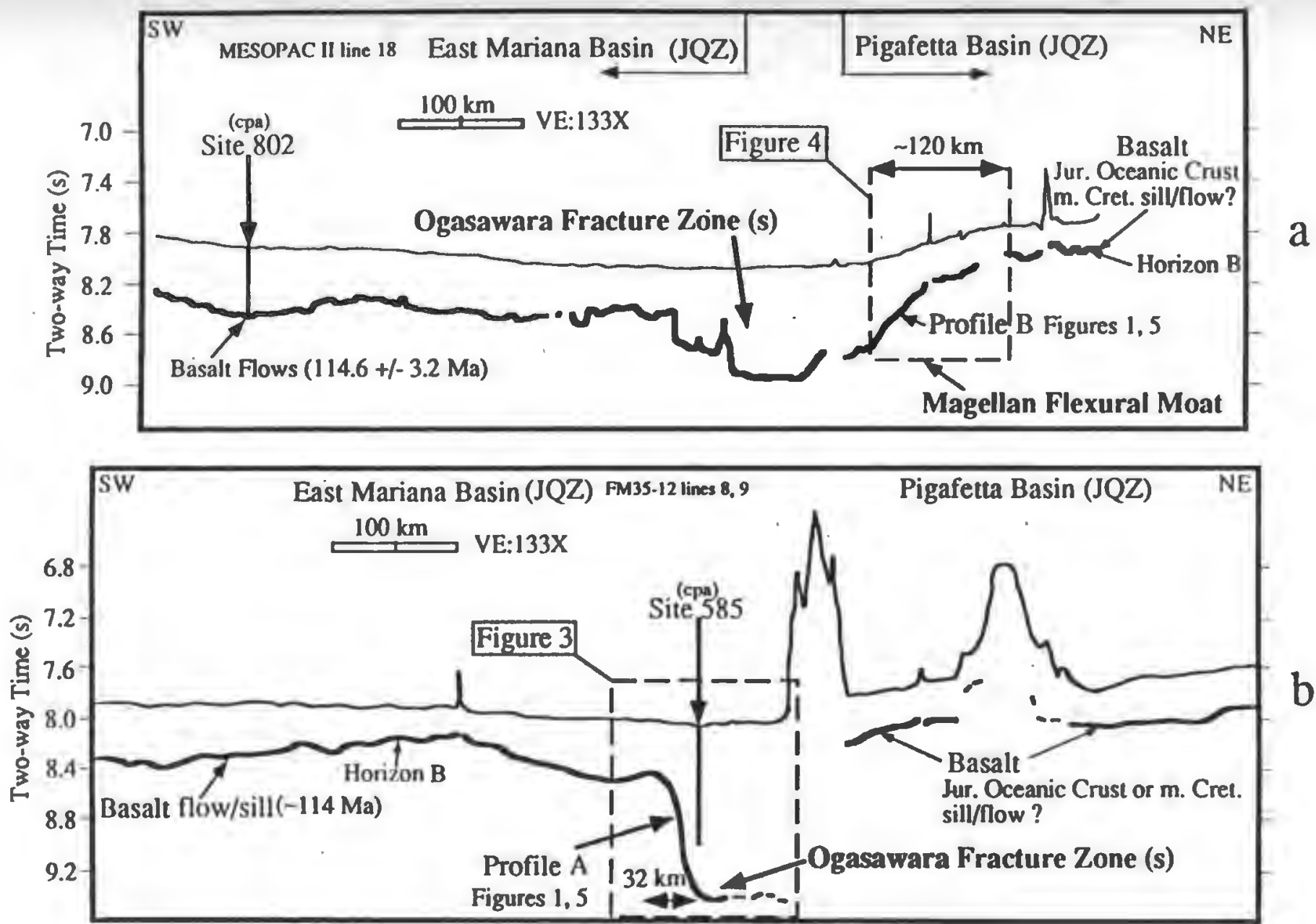
Figure 3. FM35-12 MCS airgun profile across DSDP 585 and the inferred location of the Ogasawara FZ (Marked Profile A in figure 1). Roman numerals indicate lithologic units as presented in Moberly and Schlanger, et al. (1986). High velocity Horizon B deepens over a $20-30 \mathrm{~km}$ range from approximately $300-500 \mathrm{mbsf}$ in the majority of the EMB to over 1150 mbsf at DSDP 585. Comparable deepening of the Horizon B reflector over a much larger range $(\sim 120 \mathrm{~km})$ is observed along MESOPAC II line 18 shown in figure 4. The processing and display parameters are as follows: pre-stack spike deconvolution, 120-fold stack, band-pass filter 20$60 \mathrm{~Hz}$, wave equation migration, 500 msec AGC and vertical exaggeration of $\sim 22 \mathrm{X}$ at $1.5 \mathrm{~km} / \mathrm{s}$. 
FM35-12 MCS Airguns VE:S3X
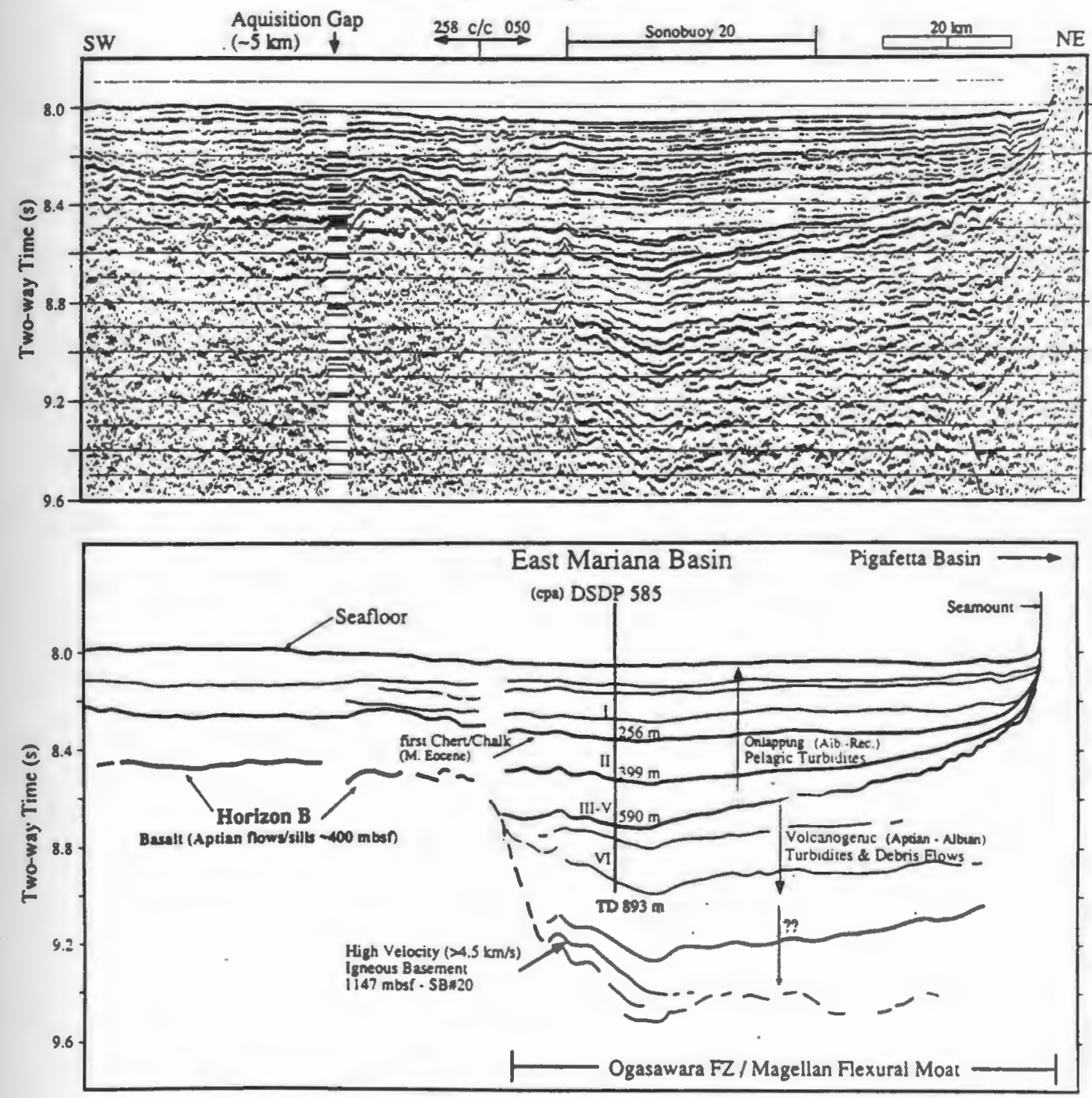
Figure 4. MESOPAC II SCS profile from the PB (right side) to the EMB crossing approximately perpendicular to the inferred trend of the Ogasawara FZ (marked profile B figure 1). The seismic image is strikingly similar to those across the Hawaiian flexural moat (Rees et al., 1991). Reflections clearly show onlapping geometries which are interpreted as moat filling debris flows and turbidites derived from the Magellan Seamounts. These seamounts are aligned along the trend of the Ogasawara Fracture Zone and appear to flexurally depress high velocity Horizon B over a $120 \mathrm{~km}$ range (e.g. flexural wavelength) on the PB side of the fracture zone. This near-channel record is processed and displayed with the following parameters: water-velocity $\mathrm{F} / \mathrm{K}$ migration, mute, 2-trace mix, bandpass filter $25-100 \mathrm{~Hz}, 500 \mathrm{msec}$ AGC, and vertical exaggeration $\sim 22 \mathrm{X}$ at 1.5 $\mathrm{km} / \mathrm{s}$. 


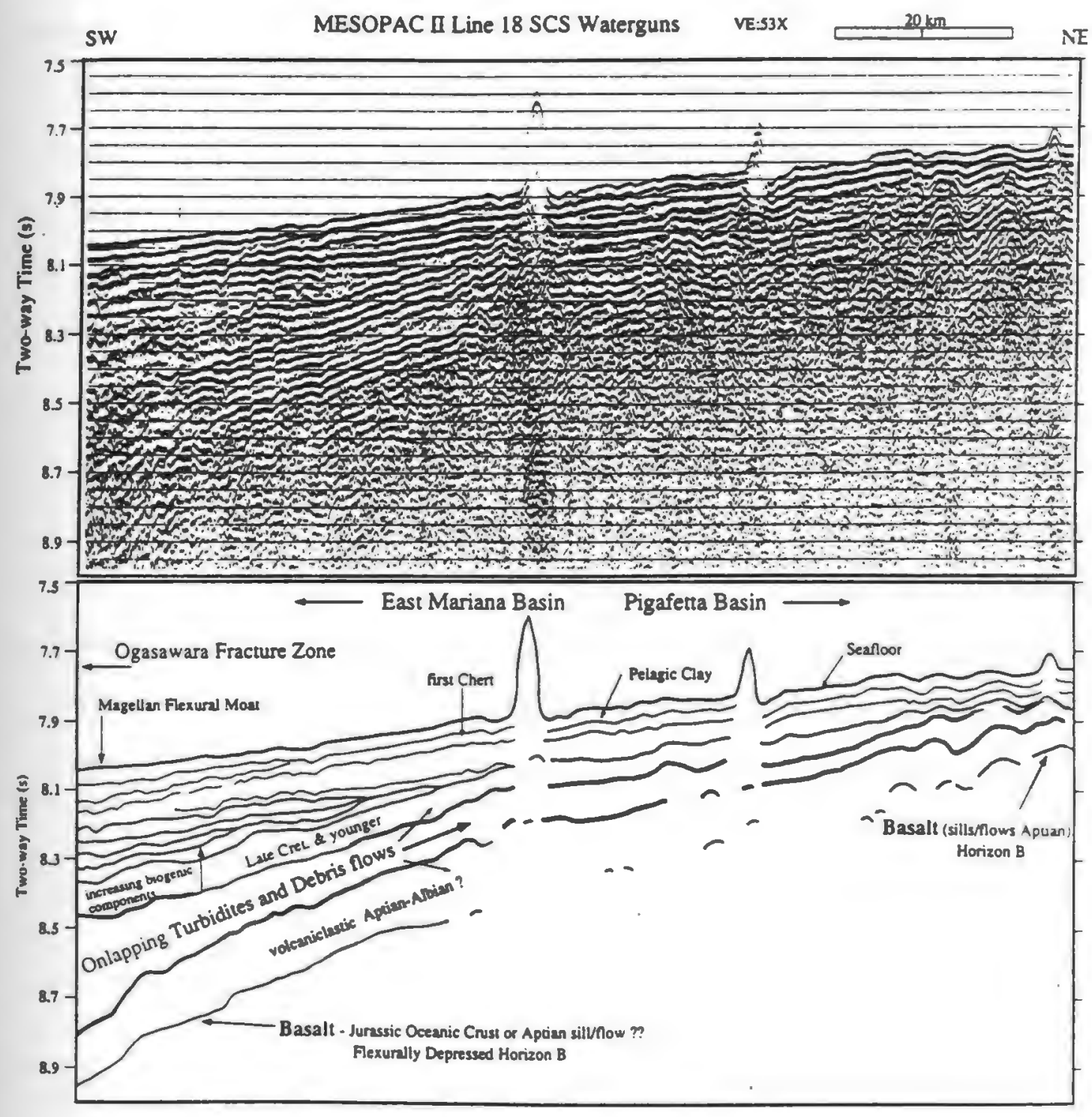


Figure 5. Relative depth to Horizon B from seismic profiles corrected for sediment loading according to Crough (1983) and Renkin and Sclater (1988). Profile B is along a MESOPAC II MCS track from the PB to the EMB ( figure 4, figure 1 location) and Profile A is along an FM35-12 MCS track from the EMB across DSDP 585 toward the PB ( figure 3). The solid line represents the calculated shape for a semi-infinite elastic plate deflected by an end line load which best matches the observed Horizon B profile. In each model the magnitude of the load was adjusted so that the calculated deflection equals the observed change in depth to Horizon B. The wavelength of the Horizon B deflection and its magnitude were the only observational constraints which resulted in model elastic plates with $\mathrm{Te}=5 \mathrm{~km}$ and $28.5 \mathrm{~km}$ for profiles A and B respectively. While Profile A can be modeled as a deflected elastic plate it also appears to deepen at a rate comparable to that of oceanic crust observed both on and off ridge as a fracture zone is approached. 
Observed Unloaded Horizon B Depths vs

Model Loaded Elastic Plate

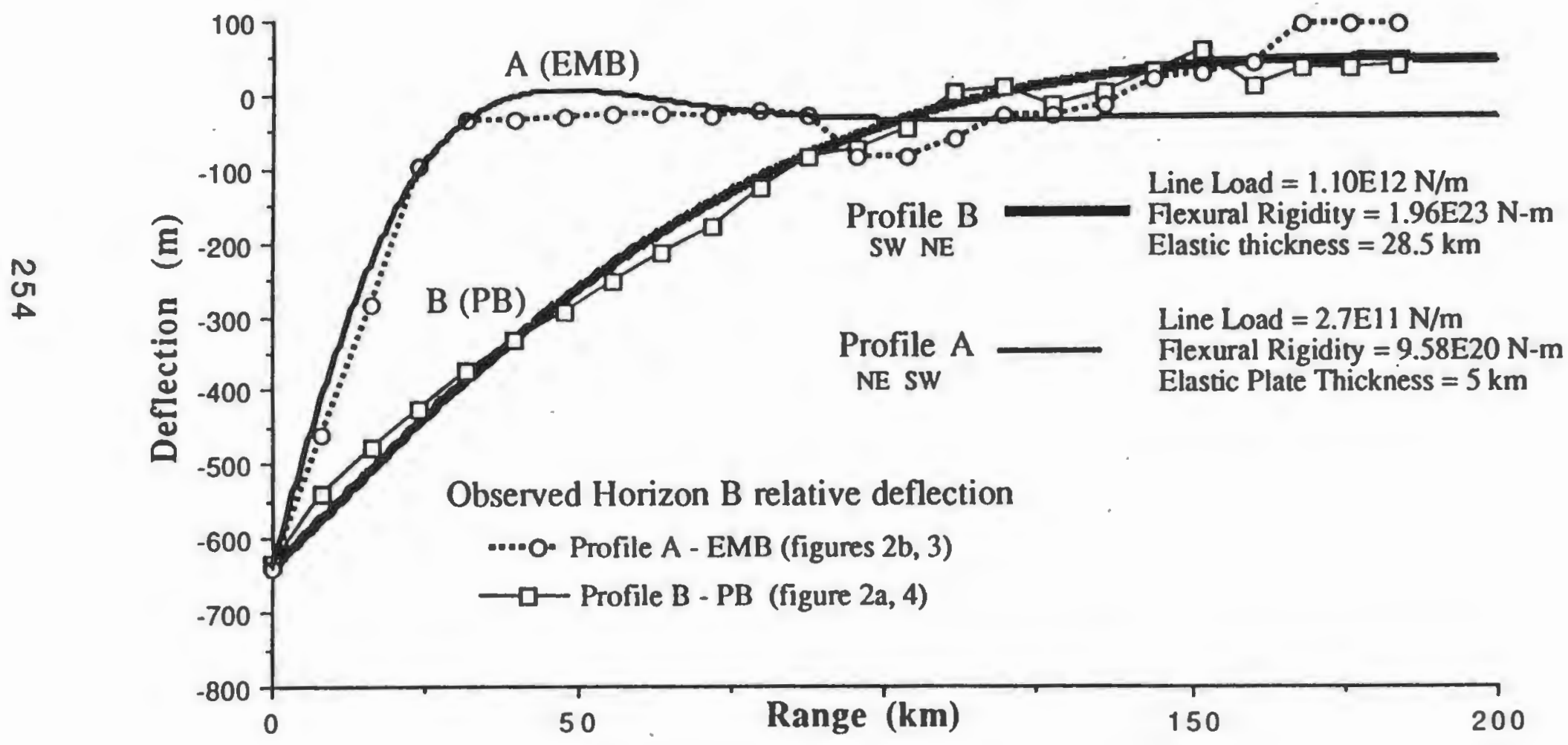


Figure 6. Relative depth to Horizon B from seismic profiles corrected for sediment loading according to Crough (1983) and Renkin and Sclater (1988). Profile B is along a MESOPAC II MCS track from the PB to the EMB ( figure 4, figure 1 location) and Profile $A$ is along an FM35-12 MCS track from the EMB across DSDP 585 toward the PB ( figure 3). The solid line represents the calculated shape for a semi-infinite continuous elastic plate deflected by a line load which best matches the observed Horizon B profile. In each model the magnitude of the load was adjusted so that the calculated deflection equals the observed change in depth to Horizon B. The wavelength of the Horizon B deflection and its magnitude were the only observational constraints which resulted in model elastic plates with $\mathrm{Te}=2.8$ $\mathrm{km}$ and $16.9 \mathrm{~km}$ for profiles A and B respectively. While Profile A can be modeled as a deflected elastic plate it also appears to deepen at a rate comparable to that of oceanic crust observed both on and off ridge as a fracture zone is approached. 
Observed Unloaded Horizon B Depths vs

Model Loaded Continuous Elastic Plate

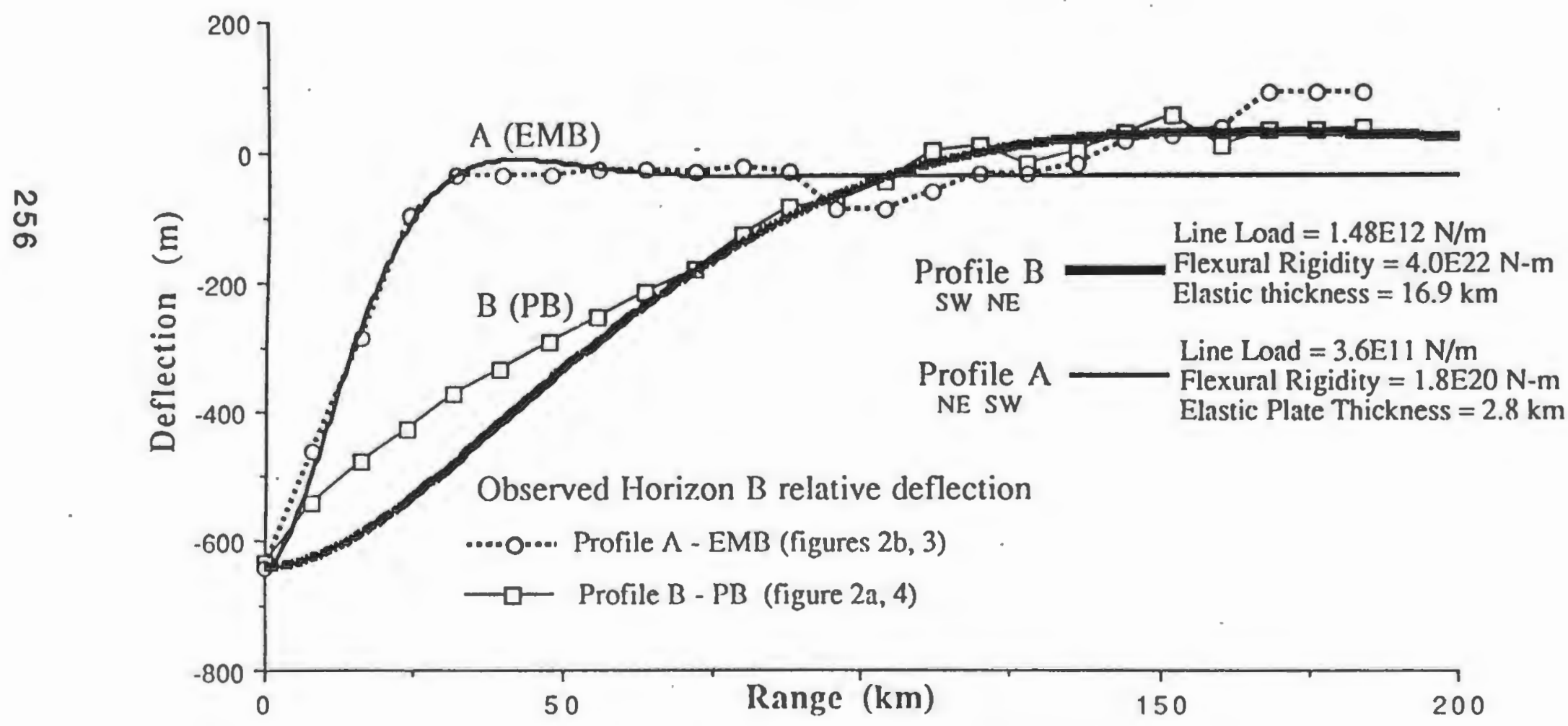




\section{BIBLIOGRAPHY}


Abrams, L. J., R. L. Larson, T. Shipley and Y. Lancelot. "Cretaceous volcanic sequences and Jurassic(?) crust in the western Pacific." EOS Transactions, American Geophysical Union 69 (1988): 1442.

Archie, G.E. "Electrical resistivity as an aid in determining some reservoir characteristics." Petroleum Transactions 146 (1942): 54-62.

Arthur, M.A., W.A. Dean and S.O. Schlanger. "Variations in the global carbon cycle during the Cretaceous related to climate, volcanism, and changes in atmospheric CO2." The carbon cycle and atmospheric CO2: Natural variations Archean to present American Geophysical Union Monograph Series 32 (1985): 504-529.

Arthur, M. A., L. R. Kump, W. E. Dean, and R. L. Larson. "Superplume, supergreenhouse?." EOS Transactions, American Geophysical Union 72 (1991): 301.

Asada, T., H. Shimamura, S. Asano, K. Kobayashi, and Y. Tomoda. "Explosion seismological experiments on long-range profiles in the Northwestern Pacific and the Marianas Sea." The Ocean Basins and Margins 7A (1985): 105-120.

Batiza, R. "Lithospheric age dependence of off-ridge volcano production in the North Pacific." Geophysical Research Letters 8 (1981): 853-856.

Batiza, R., D. Fornari, D. Vanko, and P. Londsdale. "Craters, calderas and hyaloclastites on young Pacific seamounts." Journal of Geophysical Research, 89 (1984): 87318390. 
Boyce, R.E. "Definitions and laboratory techniques of the compressional sound velocity parameters and wet-water content, wet bulk density, and porosity parameters by gravimetric and gamma ray attenuation techniques." Initial Reports of the Deep Sea Drilling Project 33 (1976): 1115-1128.

Brenner, C. and, M. Angell, M. "Bathymetric map of the East Mariana and Pigafetta Basins in the western Pacific." Proceedings of the Ocean Drilling Program Scientific Results 129 (1992 in press).

Bratt, S. R., and G. M. Purdy. "Structure and variability of oceanic crust on the flanks of the East Pacific Rise between 11 and 13N." Journal of Geophysical Research 89 (1974): 6111-6125.

Busch, W.H. Patterns of sediment compaction at Ocean Drilling Program Sites 645, 646, and 647, Baffin Bay and Labrador Sea." Proceedings of the Ocean Drilling Program Scientific Results 105 (1989): 781 - 790.

Burke, K., P. J. Fox, and A. M. C. Sengor. "Buoyant ocean floor and the evolution of the Caribbean." Journal of Geophysical Research 83 (1978): 3949-3954.

Cannon, D.E. and Coates, G.R. "Applying mineral knowledge to standard log interpretation." Society of Professional Well Log Analysts, 31st Annual Logging Symposium, paper V (1990): 23.

Carnahan, B., H. A. Luther, and J. O. Wilkes. Applied Numerical Methods: New York, 
N.Y. : John Wiley, 1969.

Castillo, P. R., and R. W. Carlson. "Possible origin of widespread Cretaceous volcanism in the Pacific: constraints from $\mathrm{Sr}, \mathrm{Nd}$, and $\mathrm{Pb}$ isotope geochemistry of Nauru Basin thoeliites." EOS Transactions, American Geophysical Union 71 (1990): 1667.

Castillo, P. R., and M. S. Pringle. "Cretaceous volcanism in the western Pacific sampled at Sites 800 and 802, ODP Leg 129." EOS Transactions, American Geophysical Union 72 (1991): 300.

Castillo, P. R., P. A., Floyd, and C, France-Lanord. "Isotope geochemistry of ODP Leg 129 basalts: implications for the origin of widespread volcanic event in the Pacific" Proceedings of the Ocean Drilling Program Scientific Results 129 (1992 in press).

Carey, S. N., H. Sigurdsson. "The Roseau Ash: Deep-Sea Tephra deposits from a major eruption on Dominica, Lesser Antilles Arc." Journal of Volcanology and Geothermal Research 7 (1980): 67-86.

Clague, D. A., R. T. Holcomb, J. M. Sinton, R. S. Detrick, and M. E. Torresan. "Pliocene and Pleistocene alkalic flood basalts on the seafloor north of the Hawaiin islands." Earth and Planetary Sciences Letters 98 (1990): 175-191.

Clavier, C., G. Coates, and J. Dumanoir. "The theoretical and experimental basis for the dual-water model for the interpretation of shaly sands." Society of Petroleum Engineers paper 6859 (1977): 1-33. 
Courtillot, V.E., J. Besse, D. Vandamme, R. Montigny, J.J. Jeager, and H. Cappetta. "Deccan flood basalts at the Cretaceous/Tertiary boundary?." Earth and Planetary Sciences Letters 80 (1987): 361-374.

Crough, S. T. "The correction for sediment loading on the seafloor." Journal of Geophysical Research 88 (1983): 6449-6454.

Davis, E. E. "Thermal aging of the oceanic lithosphere." Handbook of Seafloor Heat flow (1989): 145-167.

Detrick, R. S., and S. T. Crough. "Island subsidence, hotspots and lithospheric thinning." Journal of Geophysical Research 83 (1978): 1236-1244.

Detrick, R. S., R. P. Von Herzen, B. Parsons, D. Sandwell, and M. Dougherty. "Heat Flow observations on the Bermuda Rise and thermal models of midplate swells." Journal of Geophysical Research 91 (1986): 3701-3723.

Detrick, R. S., R. S. White, R. C. Courtney, and R. P. Von Herzen. "Heat Flow on midplate swells." Handbook of Seafloor Heat flow (1989): 169-190.

Diebold, J. B., and P. L. Stoffa. "The traveltime equation, tau-p mapping and inversion of common midpoint data." Geophysics 46 (1981): 238-254.

Doveton, J.H. Log Analysis for Subsurface Geology. New York, N.Y.: John Wiley, 1986. 
Edgar, N. T., J. B. Saunders and Scientific Party. Initial Reports of the Deep Sea Drilling Project 15. Washington D.C.: U.S. Government Printing Office, 1973.

Ewing, J., M. Talwani, M. Ewing, and T. Edgar. "Sediments of the Caribbean." International Conference on Tropical Oceanography Processes 5 (1967): 88-102.

Ewing, J., M. Ewing, T. Aitken, and W.J. Ludwig. "North Pacific sediment layers measured by seismic profiling" The Crust and Upper Mantle of the Pacific Area American Geophysical Union Monograph 12 (1968): 147-173.

Ewing, J. I., and G. M. Purdy. "Upper crustal velocity structure in the ROSE area of the East Pacific Rise." Journal of Geophysical Research 87 (1982): 8397-8402.

Fisher, A.G., and Scientific Party. Initial Reports of the Deep Sea Drilling Project. 6. Washington D.C.: U.S. Government Printing Office, 1971.

Froget, V. Recherches sur l'origine et l'evolution des bassins Mesozoiques du Pacifique centre ouest, (Doctoral thesis, Universite de Paris, 1989).

Fulthorpe, C. S., S. O. Schlanger, and R. D. Jarrard. "In situ properties of pelagic carbonate sediments on the Ontong Java Plateau." Journal of Geophysical Research 94 (1989): 4025-4032.

Harland, W. B., R. L. Armstrong, A. V. Cox, L. E. Craig, A. G. Smith, and D.G. Smith. A Geologic Time Scale 1989. Cambridge, U.K.: Cambridge University 
Press, 1990.

Handschumacher, D. W., and J.F. Gettrust. "Mixed polarity model for the Jurassic Quiet Zone : new oceanic evidence of frequent pre-M25 reversals." EOS Transactions, American Geophysical Union 66 (1985): 867.

Handschumacher, D. W., W. W. Sager, T. W. C. Hilde, and D. R. Bracey. "Pre-Cretaceous tectonic evolution of the Pacific plate and extension of the geomagnetic polarity reversal time scale with implications for the origin of the Jurassic Quiet Zone." Tectonophysics 155 (1988): 365-380.

Hamilton, E. L. "Sunken islands of the Mid-Pacific Mountains." Geoligcal Society America Memoir 64 (1956): 94.

Hamilton, E.L. "Prediction of in situ acoustic and elastic properties in marine sediments." Geophysics 36 (1971): 266-284.

Hamilton, E.L. "Variations of density and porosity with depth in deep-sea sediments." Journal of Sedimentary Petrology 46 (1976): 280-300.

Harvey, P. K., J. F. Bristow, and M. A. Lovell. "Mineral transforms and downhole geophysical measurements." Scientific Drilling 1 (1990): 163-176.

Hertzog, R., L. Colson, B. Seeman, M. O'Brien, H. Scott, D. McKeon, P. Wraight, Grau, J., J. Schweitzer, and M. Herron. "Geochemical logging with spectrometry tools." Journal of the Society of Petroleum Engineers 4 (1989): 153- 
Hays, J. D. and W.C. Pitman III. "Lithospheric plate motion, sealevel changes and ecological consequences." Nature 246 (1973): 18-22.

Hatton, L., M. H, Worthington, and J. Makin. Seismic data processing - theory and practice. Boston, MA.: Blackwell Scientifc Publications, 1986.

Heestand, R. L., and S. T. Crough. "The effect of hot spots on the oceanic age-depth relation." Journal of Geophysical Research 86 (1981): 6107-6130.

Heezen, B. C., I. D. MacGregor and Scientific Party. "Mesozoic chalks beneath the Caroline abyssal plain: DSDP Site 199." Initial Reports of the Deep Sea Drilling Project 20 (1973): 65-85.

Heezen, B.C., I.D. MacGregor, H. P. Foreman, G. Forristal, H. Hekel, R. Hesse, R.H. Hoskins, E.J.W. Jones, A. Kaneps, V.A. Krasheninnikov, H. Okada, M.H. Reuf. "Diachronous deposits: a kinematic interpretation of the post Jurassic sedimentary sequence on the Pacific. plate." Nature 241 (1973): 25-32.

Helsley, C.E. and M.B. Steiner. "Evidence for long intervals of normal polarity during the Cretaceous period." Earth and Planetary Sciences Letters 5 (1969): 325-332.

Hilde, T. W. C., N. Isezaki, and J. M. Wageman. "Mesozoic seafloor spreading in the North Pacific." The Geophysics of the Pacific Ocean Basin and its Margins, American Geophysical Union Monograph Series 19 (1976): 205-226. 
Hilde, T. W. C., S. Uyeda, and L. Kroenke. "Evolution of the western Pacific and its margin." Tectonophysics 38 (1977): 145-165.

Houtz, R. E., J. Ewing, and P. Buhl. "Seismic data from sonobuoy stations in the northern and equatorial Pacific." Journal of Geophysical Research 75 (1970): 50935111.

Houtz, R. E. "Seismic properties of Layer 2A in the Pacific" Journal of Geophysical Research 81 (1976): 6321-6331.

Houtz, R., and J. Ewing, Upper crustal structure as a function of plate age, Journal of Geophysical Research, 81, 2490-2498, 1976.

Houtz, R. E., and W. J. Ludwig. "Structure of Columbia Basin, Caribbean Sea, from profiler-sonobuoy measurements." Journal of Geophysical Research 82 (1977): 4861-4868.

Houtz, R. E. "Interval velocities in crustal layers from sonobuoy records of mantle reflections." Journal of Geophysical Research 82 (1977): 5395-5400.

Houtz, R. E., and W. J. Ludwig. "Distribution of reverberant subbottom layers in the southwest Pacific basin." Journal of Geophysical Research 84 (1979): 3497-3505.

Houtz, R.E. "Crustal structure of the North Atlantic on the basis of large-airgunsonobuoy data." Geological Society of America Bulliten 91 (1980): 406-413. 
Hussong, D. M., S. Uyeda and Scientific Party. "Site 452: Mesozoic Pacific Ocean Basin." Initial Reports Deep Sea Drilling Project 60 (1981): 88-93.

Jarrard, R. D., and D. A. Clague. "Implications of Pacific island and seamount ages for the origin of volcanic chains." Reviews of Geophysics and Space Physics 15 (1977): 57-76.

Jarrard, R.D., K. A. Dadey, and W. H. Busch. "Velocity and density of sediments of Eirik Ridge, Labrador Sea: control by porosity and mineralogy." Proceedings of the Ocean Drilling Program Scientific Results 105 (1989): 811-835.

Keating, B. H., D.P. Mattey, J. Naughton, and C. E. Helsley. "Age and origin of Truk Atoll, eastern Caroline Islands: Geochemical, radiometric-age, and paleomagnetic evidence." Geological Society of America Bulletin 95 (1984): 350-356.

Kellogg, J. N., B. S. Wedgeworth, and J. Freymueller. "Isostatic compensation and conduit structures of western Pacific seamounts: results of three dimensional gravity modeling." Seamounts, Islands, and Atolls. American Geophysical Union Monograph 43 (1987): 85-95.

Kent, D. V., and F. M. Gradstein. "A Cretaceous and Jurassic geochronology" Geological Society of America Bulletin 96 (1985): 1419-1427.

Kominz, M. A. "Ocean ridge volumes and sea-level change - An error analysis." American Assocition of Petrolem Geologists Memoir 36 (1984): 108-129. 
Kroenke, L. W., and W. H. Berger and Scientific Party. Proceedings of the Ocean Drilling Program Initial Results 130. College Station, TX.: Ocean Drilling Program, 1991.

Lancelot, Y., and R.L Larson. "Sedimentary and Tectonic Evolution of the Northwestern Pacific." Initial Reports of the Deep Sea Drillin Project 32 (1973): 925-939.

Lancelot, Y., R. L. Larson and Scientific Party. Proceedings of the Ocean Drilling Program Initial Results 129. College Station, TX.: Ocean Drilling Program, 1990.

Larson, R.L. and C. G. Chase. "Late Mesozoic evolution of the western Pacific Ocean." Geological Society of America Bulletin 83 (1972): 3627-3644.

Larson, R. L. and W. C. Pitman III. "World-wide correlations of Mesozoic magnetic anomalies, and its implications." Geological Society of America Bulletin 83 (1972): 3645-3661.

Larson, R.L. and Chase, C. G. "Late Mesozoic evolution of the western Pacific Ocean." Geological Society of America Bulletin 83: 3627-3644, 1972

Larson, R. L. and T. W. C. Hilde. "A revised time scale of magnetic reversals for the Early Cretaceous and Late Jurassic" Journal of Geophysical Research 80 (1975): 2586-2594.

Larson, R. L., Moberly R. and Scientific Party. Initial Reports of the Deep Sea Drilling 
Project 32. Washington D. C.: U.S. Govemment. Printing Office, 1973.

Larson, R. L., and W. Lowrie. "Paleomagnetic evidence for motion of the Pacific plate from Leg 32 basalts and magnetic anomalies." Initial Reports of the Deep Sea Drilling Projectt 32 (1975): 571-577.

Larson, R.L. "Late Jurassic and Early Cretaceous evolution of the western central Pacific Ocean." Journal of Geomagnetism and Geolectricity 28 (1976): 219-236.

Larson, R.L., S. O. Schlanger and Scientific Party. Initial Reports of the Deep Sea Drilling Project 61. Washington D. C.: U.S. Government. Printing Office, 1981.

Larson, R. L.. "Latest pulse of the Earth: Evidence for a mid-Cretaceous super plume." Geology 19 (1991): 547-550.

Larson, R. L. "Geologic consequences of super plumes" Geology 19 (1991): 963-966.

Larson, R. L., and W. W. Sager. "Skewness of magnetic anomalies M0 to M29 in the northwestem Pacific." Proceedings of the Ocean Drilling Program Scientific Results 129, in press 1992.

Le Pichon, X., J. Ewing, and R. Houtz. "Deep-sea sediment velocity determinationmade while reflection profiling." Journal of Geophysical Research 73 (1968): 2597 2614.

Lincoln, J. M., M. S. Pringle, and I. Primoli Silva. "Early and Late Cretaceous volcanism 
and reef building in the Marshall Islands: new fossil evid ence and ${ }^{40} \mathrm{Ar} / 39 \mathrm{Ar}$ ages, EOS Transactions, American Geophysical Union 71 (1990): 1667.

Lincoln, J. M., M. S. Pringle, and I. Primoli Silva, Early and Late Cretaceous volcanism and reef-building in the Marshall Islands: new fossil evidence and ${ }^{40} \mathrm{Ar} / 39 \mathrm{Ar}$ ages." The Mesozoic Pacific. American Geophysical Union Monograph, 1992 in press.

Lipman, P. W., D. A. Clague, and R. T. Holcomb. "South arch volcanic field - newly identified young lava flows on the sea floor south of the hawaiin ridge." Geology 17 (1989): 611-614.

Lister, C. R. B., J. G. Sclater, E. E. Davis, H. Villinger, and S. Nagihara. "Heat flow maintained in ocean basins of great age: Investigations in the North equatorial west Pacific." Geophisical Journal International 102 (1990): 603-630.

Lowrie, A., C. N. Smoot, and R. Batiza. "Are oceanic fracture zones strong or weak? New evidence for volcanic activity and weakness." Geology 14 (1986): 242-245.

Ludwig, W. J., R. E. Houtz, and J . I. Ewing. "Profiler-sonobuoy measurements in the Columbia and Venezuela Basins, Caribbean Sea." American Association of Petroleum Geologists Bulletin 59 (1975): 115-123.

Macdonald, K. C. "Mid-ocean ridges: Fine scale tectonic, volcanic and hydrothermal processes within the plate boundary zone." Annual Reviews of Earth and Planetary Sciences 10 (1982): 155-190. 
Mahoney, J. J., and J. A.Tarduno. "Cretaceous volcanism and the formation of the Ontong-Java plateau: new insights from ODP Leg 130" EOS Transactions, American Geophysical Union 71 (1990): 1668.

Mahoney, J. J., and K. J. Spencer. "Isotopic evidence for the origin of the Manihiki and Ontong-Java plateaus." Earth and Planetary Sciences Letters 104 (1991): 196-210.

Mammerickx, J., and G.F. Sharman. "Tectonic evolution of the North Pacific during the Cretaceous quiet period." Journal of Geophysical Research 93 (1988): 3009-3040.

Mcnutt, M., and K. M. Fischer. "The South Pacific Superswell." Seamounts, Islands, and Atolls. American Geophysical Union Monograph 43 (1987): 25-34.

Menard, H. W. Marine Geology of the Pacific. New York, NY.: McGraw Hill Book Company, 1964.

Menard, H. W., and J. Mammwerickx. "Abyssal hills, magnetic anomalies and the East Pacific Rise." Earth and Planetary Sciences Letters 2 (1967): 465-472.

Moberly, R., S. O. Schlanger and Scientific Party. Initial Reports of the Deep Sea Drilling Project 89. Washington D.C.: U.S. Government. Printing Office, 1986.

Nakanishi, M., K. Tamaki, and K. Kobayashi. "Mesozoic magnetic anomaly lineations and seafloor spreading history of the northwestern Pacific." Journal of Geophysical Research 94 (1989): 15,437-15,462. 
Nakanishi, M., K. Tamaki, and K. Kobayashi. "Magnetic anomaly lineations from Late Jurassic to Early Cretaceous in the west-central Pacific Ocean" Geophysical Journal International, in press 1992.

Neumann, G., and Pierson, W. J., Jr. Principles of Physical Oceanography : Englewood Cliffs, N.J.: Prentice-Hall, 1966.

Ozima, M., I. Kaneoka, K. Saito, M. Honda, M. Yanagisawa, and Y. Takigami.

"Summary of geochronological studies of submarine rocks from the western Pacific Ocean." Geodynamics of the western Pacific-Indonesian region. 11 (1983): 137142.

Parsons, B., and J. G. Sclater. "An analysis of the variation of ocean floor heat flow and bathymetry with age." Journal of Geophysical Research 82 (1977): 803-827.

Parsons, B., and D. McKenzie. "Mantle convection and the thermal structure of the plates." Journal of Geophysical Research 83 (1978): 4485-4496.

Pringle, M. S. "Radiometric ages of basaltic basement recovered by ODP Leg 129." Proceedings of the Ocean Drilling Program Scientific Results 129, in press 1992.

Pringle, M. Geochronology and petrology of the Musicians Seamounts and the search for hot spot volcanism in the Cretaceous Pacific, (Doctoral dissertation, University of Hawaii, Honolulu, 1992).

Purdy, G. M. "The seismic structure of 140 my old crust in the Central Atlantic Ocean." 
Geophysical Journal of the Royal Astronomical Society 72 (1983): 115-138.

Raitt, R. W. "The Crustal Rocks." The Sea 3 (1963): 85-102.

Rees, B. A., R. S. Detrick, and B. C. Coakley. "Seismic stratigraphy of the Hawaiian flexural moat." Geological Society of America Bulliten (in press 1992).

Renkin, M., and J. G. Sclater. "Depth and Age in the North Pacific." Journal of Geophysical Research 93 (1988): 2919-2935.

Richards, M. A., R. Duncan, and V. Courtillot. "Flood basalts and hot-spot tracks: plume heads and tails." Science 246 (1989): 103-107.

Sager, W. W., and M. S. Pringle. "Mid-Cretaceous to Early Tertiary apparent polar wander path of the Pacific plate." Journal of Geophysical Research 93 (1988): $11,753-11,771$.

Sager, W.W., D.W. Handschumacher, T.W.C. Hilde, and D.R. Bracey. "Tectonic evolution of the northern Pacific plate and Pacific-Farallon-Izanagi triple junction in the Later Jurassic and Early Cretaceous (M21-M10)." Tectonophysics 155 (1988): 345-364.

Saunders, J. B., N. T. Edgar, T. W. Donnelly, and W. W. Hey. "Cruise synthesis." Initial Reports of the Deep Sea Drilling Project 15 (1973): 1077-1111.

Schlanger, S. O., H. C. Jenkyns, and I. Premoli-Silva. "Volcanism and vertical tectonics 
in the Pacific basin related to global Cretaceous transgressions." Earth and Planetary Sciences Letters 52 (1981): 435-449.

Schlanger, S. O., J. F. Cambell, and M. W. Jackson. "Post-Eocene subsidence of the Marshall Islands recorded by drowned atolls on Harrie and Sylvania Guyots." Seamounts, Islands, and Atolls American Geophysical Union Monograph 43 (1987): 165-174.

Schmincke, H.-U. and U. von Rad. "Neogene evolution of Canary Island volcanism inferred from layers and volcaniclastic sandstones of DSDP Site 397." Initial Reports of the Deep Sea Drilling Project 47 (1979): 703-716.

Schubert, G., and D. Sandwell. "Crustal volumes of the continents and of oceanic plateaus and continental submarine plateaus." Earth Planet. Sci. Lett., 92 (1989): 234-246.

Serra, O. Fundamentals of Well-log Interpretation: 2. The Interpretation of Logging Data: Amsterdam, Elsevier, 1984.

Sheriff, R.E. "Seismic Stratigraphy - applications to hydrocarbon exploration." American Assocition of Petrolem Geologists Memoir 26, (1977): 3-14.

Shipley, T. H., J. M. Whitman, F. K. Duennebier, and L. D. Peterson. "Seismic stratigraphy of the East Mariana Basin, western Pacific." Earth and Planetary Sciences Letters 64 (1983): 257-275. 
Shipley, T. H., L. J. Abrams, R.L. Larson, and Y. Lancelot. "Extent of Cretaceous volcanic sequences in the Jurassic Nauru Basin, western Pacific." EOS Transactions, American Geophysical Union 72 (1991): 503.

Shipley, T. H., L. J. Abrams, R.L. Larson, and Y. Lancelot. "Extent of Cretaceous volcanic sequences in the Jurassic Nauru Basin, western Pacific." The Mesozoic Pacific American Geophysical Union Monograph, in press 1992.

Sigurdsson, H., R. S. J. Sparks, S. N. Carey, and T. C. Huang. "Volcanogenic sedimentation in the Lesser Antilles Arc." Journal of Geology 88 (1980): 523540.

Smith, W.H.F., H. Staudigel, A.B. Watts, and M. Pringle. "The Magellan Seamounts: Early Cretaceous record of the South Pacific isotopic and thermal anomaly." Journal of Geophysical Research 94 (1989): 10,501-10,523.

Spudich, P., and J. A. Orcutt. "A new look at the seismic velocity structure of the oceanic crust." Reviews of Geophysics and Space Physics 18 (1980): 627-645.

Stein, C. A. and D. H. Abbot. "Heat flow constraints on the south Pacific superswell." Journal of Geophysical Research 96 (1991): 16,083 - 16100.

Steiner, M., J. Ogg, and J. Sandoval. "Jurassic magnetostratigraphy, 3. BathonianBajocian of Carcabuey, Sierra Harana and Campillo de Arenas (Subbetic Cordillera southern Spain)." Earth and Planetary Sciences Letters 82 (1987): 357-372. 
Steiner, M. B., and B. C. Wallick. "Paleomagnetism of the sedimentary sequences of Sites 800,801 and 802 , Leg 129 and the Jurassic to Paleogene paleolatitudes of the Pacific plate." Proceedings of the Ocean Drilling Program Scientific Results 129, in press 1992.

Stoffa, P. L., A. Mauffret, M. Truchan, and P. Buhl. "Sub-B" layering in the southern Caribbean: The Aruba and Venezuela Basin." Earth and Planetary Sciences Letters 53 (1981): 131-146.

Talwani, M., C. C. Windisch, P. L. Stoffa, P. Buhl, and R. E. Houtz. "Multi-channel seismic study in the Venezuelan Basin and the Curacao ridge." Island Arcs, Deep Sea Trenches and Back-Arc Basins, American Geophysical Union Monograph, M. Ewing Series 1 (1977): 83-98

Tamaki, K. and R. L. Larson. "The Mesozoic tectonic history of the Magellan microplate in the Western Central Pacific." Journal of Geophysical Research 93 (1988): 2857-2874.

Tamaki, K., M. Nakanishi, K. Sayanagi and K. Kobayashi. "Jurassic magnetic anomaly lineations of the Western Pacific and the origin of the Pacific plate." EOS Transactions, American Geophysical Union 68 (1987): 1493.

Tarduno, J. A., W. V. Sliter, L. Kroenke, M. Leckie, H. Mayer, J. J. Mahoney, R. Musgrave, M. Storey, and E. L. Winterer. "Rapid formation of the Ontong-Java Plateau by Aptian mantle plume volcanism." Science 254 (1991): 399-403. 
ten Brink, U.S., and A.B. Watts. "Seismic stratigraphy of the flexural moat flanking the Hawaiin Islands." Nature 317 (1985): 421-424.

Tissot, B. "Effects on prolific petróleum source rocks and major coal deposits caused by sea-level changes." Nature 277 (1979): 463-465.

Turcotte, D.L., and G. Schubert. Geodynamics - application of continuum physics to geological problems. New York, N.Y.: Wiley, 1982.

van den Oord, R.J. "Experiences with geochemical logging." Society of Professional Well Log Analysts, 31st Annual Logging Symposium (1990): 24.

Vera, E. E., and J. C. Mutter. "Crustal structure in the ROSE area of the East Pacific Rise: one-dimensional travel time inversion of sonobuoys and expanding spread profiles." Journal of Geophysical Research 93 (1988): 6635-6648.

Vera, E. E., J. C. Mutter, P. Buhl, J. A. Orcutt, A. J. Harding, M. E. Kappus, R. S. Detrick, and T. M. Brocher. "The structure of 0- to 0.2-m.y.-old oceanic crust at 9N on the East Pacific Rise from expanding spread profiles." Journal of Geophysical Research 95 (1990): 15,529-15,556.

Vogt, P. R. "Volcano spacing, fractures and thickness of the lithosphere." Earth and Planetary Sciences Letters 21 (1974): 235-252.

Von Herzen, R. P., M. J. Cordery, R. S. Detrick, and Changle Fang. "Heat Flow and the thermal origin of hot spot swells: The Hawaiian Swell revisited." Journal of 
Geophysical Research 94 (1989): 13,783-13,799.

Von Herzen, R.P., T.J.G. Francis, and K. Becker. "In situ large-scale electrical resistivity of oceanic crust, Hole 504B." Initial Reports of the Deep Sea Drilling Project 69 (1983): 427-454.

Walcott, R. I. "Flexural rigidity, thickness, and viscosity of the lithosphere." Journal of Geophysical Research 75 (1970): 3941-3954.

Watts, A. B., J. H. Bodine, and N. M. Ribe. "Observations of flexure and the geological evolution of the Pacific Ocean Basin." Nature 283 (1980): 532-537.

Watts, A. B., J. H. Bodine, and M. S. Steckler. "Observations of flexure and the state of stress in the oceanic lithosphere." Journal of Geophysical Research 85 (1980): 6369-6376.

Watts, A. B., and N. M. Ribe. "On geoid heights and flexure of the lithosphere at seamouts." Journal of Geophysical Research 89 (1984): 11,152-11,170.

Watts, A. B., U. S. ten Brink, P. Buhl, and T. M. Brocher. "A multichannel study of the lithospheric flexure across the Hawaiian-Emperor seamount chain." Nature 315 (1985): 105-111.

Waxman, M.H., and L. J. M. Smits. "Electrical conductivities in oil-bearing shaly sands." Journal of the Society of Petroleum Engineers 8 (1968): 107-122. 
Wedgeworth, B., and J. Kellogg. "A 3-D gravity - tectonic study of Ita Mai Tai Guyot: an uncompensated seamount in the East Mariana Basin." Seamounts, Islands, and Atolls American Geophysical Union Monograph 43 (1987): 73-84.

Weissel, J.K. and R.N. Anderson. "Is there a Caroline plate?" Earth and Planetary Sciences Letters 41 (1978): 143-158.

Whitman, J. M., M. Baltuck and J. A. Haggerty. "Turbidite sedimentology and history of the East Mariana Basin." Initial Reports of the Deep Sea Drilling Project 89 (1986): 365-387.

Wendlandt. R.F., and K. Bhuyan. "Estimation of mineralogy and lithology from geochemical log measurements." American Association of Petroleum Geologist Bulletin 74 (1990): 837-856.

Winsauer, W.O., H. M. Shearin Jr., P. H. Masson, and M. Williams. "Resistivity of brine saturated sands in relation to pore geometry." American Association of Petroleum Geologist Bulletin 36 (1952): 253-277.

Wipperman, L. K., R. L. Larson, and D. M. Hussong. "The geological and geophysical setting near site 462." Initial Reports of the Deep Sea Drilling Project 61 (1981): 763-770.

Winterer, E. L. and Scientific Party. Initial Reports of the Deep Sea Drilling Project 7. Washington D.C.: U.S. Government Printing Office, 1971. 
Winterer, E. L., J. Ewing and Scientific Party. Initial Reports of the Deep Sea Drilling Project 17. Washington D.C.: U.S. Government Printing Office, 1973.

Winterer, E. L. "Anomalies in the tectonic evolution of the Pacific." The Geophysics of the Pacific Ocean Basin and its Margin. American Geophysical Union Monograph 19 (1976): 269-278.

Winterer, E. L., R. A. Duncan, M. K. McNutt, J. H. Natland, I. Premoli Silva, W. W. Sager, W. V. Sliter, R. Van Waasberger, and C. J. Wolfe. "Cretaceous guyots in the northwest Pacific: An overview of their geology and geophysics." The Mesozoic Pacific American Geophysical Union Monograph, in press 1992.

White, R. S. "Oceanic upper crustal structure from variable angle seismic reflection refraction profiles." Geophysical Journal of the Royal Astronomical Society 57 (1979): 683-726.

White, R. S. "Atlantic oceanic crust: seismic structure of a slow-spreading ridge." Ophiolites and Oceanic Lithosphere Geological Society of London (1984): 101111. 